\title{
Gatekeepers of sustainability
}

Citation for published version (APA):

Ibnu, M. (2017). Gatekeepers of sustainability: on coffee smallholders, standards and certifications in Indonesia. [Doctoral Thesis, Maastricht University]. Datawyse / Universitaire Pers Maastricht. https://doi.org/10.26481/dis.20170927mi

Document status and date:

Published: 01/01/2017

DOI:

10.26481/dis.20170927mi

Document Version:

Publisher's PDF, also known as Version of record

\section{Please check the document version of this publication:}

- A submitted manuscript is the version of the article upon submission and before peer-review. There can be important differences between the submitted version and the official published version of record.

People interested in the research are advised to contact the author for the final version of the publication, or visit the DOI to the publisher's website.

- The final author version and the galley proof are versions of the publication after peer review.

- The final published version features the final layout of the paper including the volume, issue and page numbers.

Link to publication

\footnotetext{
General rights rights.

- You may freely distribute the URL identifying the publication in the public portal. please follow below link for the End User Agreement:

www.umlib.nl/taverne-license

Take down policy

If you believe that this document breaches copyright please contact us at:

repository@maastrichtuniversity.nl

providing details and we will investigate your claim.
}

Copyright and moral rights for the publications made accessible in the public portal are retained by the authors and/or other copyright owners and it is a condition of accessing publications that users recognise and abide by the legal requirements associated with these

- Users may download and print one copy of any publication from the public portal for the purpose of private study or research.

- You may not further distribute the material or use it for any profit-making activity or commercial gain

If the publication is distributed under the terms of Article $25 \mathrm{fa}$ of the Dutch Copyright Act, indicated by the "Taverne" license above, 
Cover Picture: (C Copyright Muhammad Ibnu, Maastricht 2017

Printing: Datawyse | Universitaire Pers Maastricht

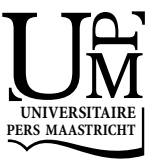

ISBN 9789461597434 


\title{
Gatekeepers of sustainability
}

\section{On coffee smallholders, standards and certifications in Indonesia}

\author{
DISSERTATION \\ to obtain the degree of Doctor at Maastricht University, \\ on the authority of the Rector Magnificus, Prof.dr. Rianne M. Letschert \\ in accordance with the decision of the Board of Deans, \\ to be defended in public \\ on Wednesday 27 September 2017, at 10.00 hours
}

by

Muhammad Ibnu

Born on 18 May 1979 in Teluk Betung Bandar Lampung, Indonesia 


\section{Supervisors}

Prof. dr. Pieter Glasbergen

Prof. dr. Bustanul Arifin (Lampung University)

\section{Co-supervisor}

Dr. Ron Cörvers

\section{Assessment Committee}

Prof. dr. Pim Martens (chair)

Dr. Jacqueline Vel (University of Leiden)

Prof. dr. Ruerd Ruben (Wageningen University)

Dr. Surip Mawardi (ICCRI, Indonesia)

Prof. dr. Wan Abbas Zakaria (Lampung University)

This PhD research was funded by the Royal Netherlands Academy of Arts and Sciences (KNAW) and the Directorate General of Higher Education (DIKTI) of the Ministry of Education and Culture of Indonesia and part of the SPIN project on "Social and Economic Effects of Partnering for Sustainable Change in Agricultural Commodity Chains in Indonesia". 


\section{Table of contents}

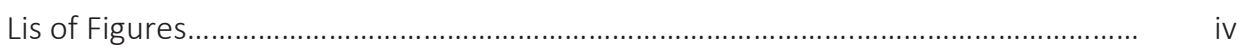

List of Tables............................................................................................................

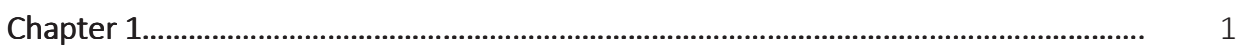

Introduction...................................................................................................... 1

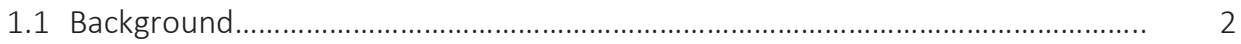

1.2 Profile of the Indonesian coffee smallholders......................................................... 4

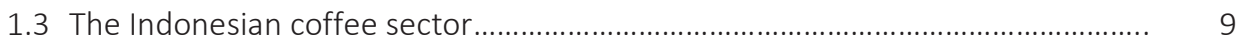

1.4 The world of certifications in Indonesia................................................................... 13

1.5 The debate on sustainability standards and certifications.................................... 16

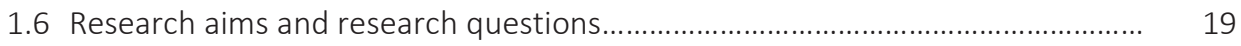

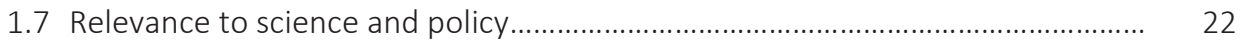

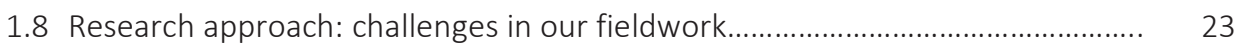

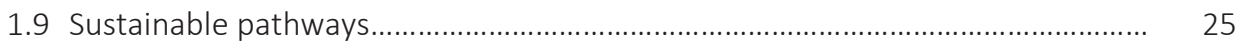

Chapter 2 ................................................................................................................... 27

Farmer preferences for coffee certification: a conjoint analysis of the Indonesian smallholders.

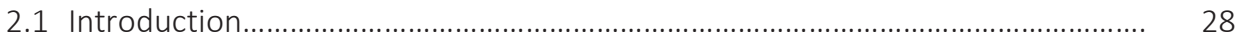

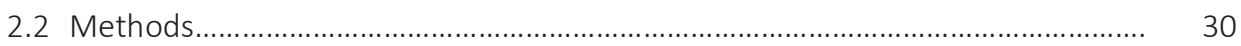

2.3 Farmer preferences and the ideal certification scheme..................................... 36

2.4 Assumptions underlying farmer's preferences................................................. 38

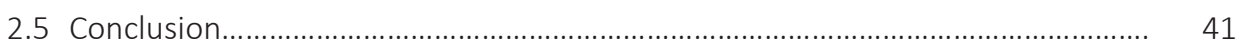

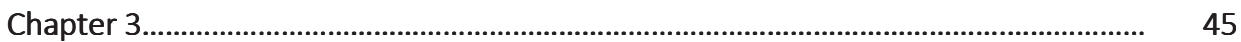

Competing explanations for Indonesian smallholder participations in sustainability coffee certifications

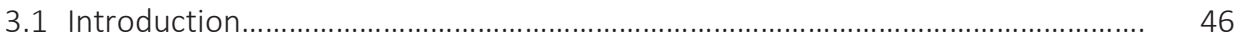

3.2 Explanations for smallholder participation in sustainability coffee certification: a review of the literature................................................................. 47

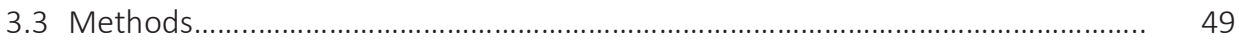

3.4 Explanations for the Indonesian smallholders to participate in sustainable coffee certification. 


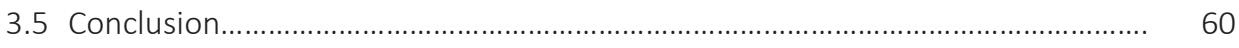

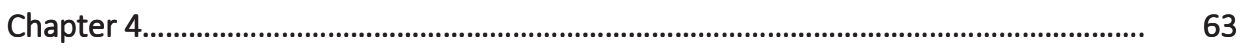

Perceived impacts of certification and farmer organization: benefits from the Indonesian smallholders' point-of-view..

4.1 Introduction

4.2 Literature review on potential benefits of farmer organization and certification.

4.3 The landscape of farmer organizations in Indonesia.

4.4 Methods.

4.5 Different organizations and their relation to certification.

4.6 The influence of organizations and certification schemes on perceived benefits.

4.7 Conclusion

Chapter 5

The public Indonesian standard on sustainable coffee: an exploration of its implementation capacity.

5.1 Introduction.

5.2 Indonesian Standard Coffee (ISCoffee): the main principles and criteria.

5.3 Analytical framework

5.4 Methods

5.5 Results

5.6 Conclusions

Chapter 6 .

Conclusions and reflection

6.1 Introduction.

6.2 Farmers' values regarding sustainability standards and certification schemes.

6.3 On the relevance of farmer organizations.

6.4 A pathway toward sustainability in the Indonesian smallholder coffee production system.

6.5 On future studies. 
References.

Appendix 1. Display of full profiles (orthogonal design)............................................... 140

Appendix 2. Preliminary list of attributes and levels of certification program.............. 142

Appendix 3. The descriptive statistic of respondents to the conjoint survey............... 143

Appendix 4. Variable, operationalization and question item ........................................ 144

Appendix 5. Question items for all farmers.................................................................. 146

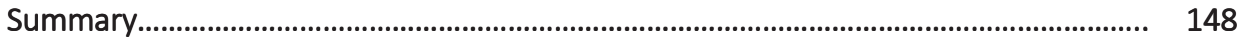

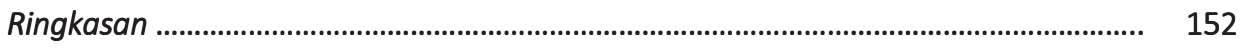

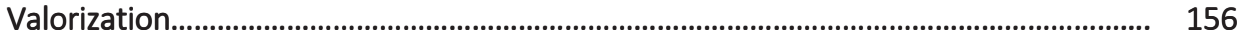

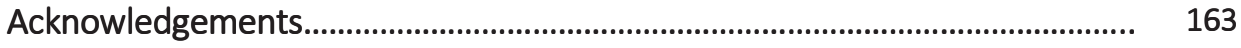

List of abbreviations and acronyms........................................................................... $\quad 165$

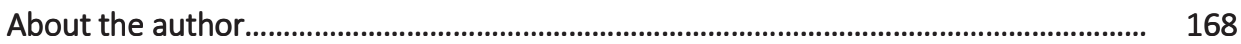




\section{List of Figures}

Figure 1 Supply chain models for organized and independent smallholder.... 8

Figure $2 \quad$ Export markets of the Indonesian coffee............................................ 10

Figure 3 The fifteen most significant Robusta producers in the world............. 12

Figure 4 Differences in perceived benefits resulting from farmers' participation in different certification schemes.................................. 78

Figure $5 \quad$ Building blocks to analyze the implementation capacity of ISCoffee

Figure 6 Five building blocks as a pathway for a more sustainable coffee production system 


\section{List of Tables}

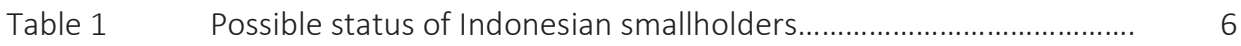

Table $2 \quad$ Coffee production and consumption in Indonesia............................... 9

Table 3 Destination for Indonesian coffee exports (2006-2015)..................... 10

Table $4 \quad$ Coffee produced in the provinces of Aceh and Lampung, Sumatra... 11

Table 5 The development of coffee plantation areas in Indonesia, in hectares.

Table 6 Comparison of sustainability standards and certification in Indonesia.

Table 7 The final list of attributes and attribute levels of Certification Programs

Table 8 Respondent types, location of interviews and the number of respondents.

Table 9 The results of means comparison with One-way Anova

Table 10

Average part-worth (utility estimate) for key attributes of coffee certification program and relative importance of each attribute......

Table 11 Attribute level summary of the most preferred certification scheme

Table 12 Operationalization of the variables.

Table 13 Sample sizes and respondent distributions.

Table 14

Table 14. Regression with Heckman selection model (the first step)......

Table 15 Table 15. Regression with Heckman selection model (the second step).

Table 16 The Bonferroni test results of One Way Anova for multiple comparisons of certification schemes.

Table 17 Types of respondents, based on participation in certification and group membership.

Table 18

Test of Parallel Lines.

Table 19 Organizational characteristics of farmer groups, KUBEs, and cooperatives

Table 20

The mean score of the perceived benefits

Table 21 Independent sample t- test for equality of means (participation in 
certification)

Table 22 Independent sample t- test for equality of means (participation in organization)

Table 23 Multiple comparisons of different certification schemes on the perceived benefits (Anova test)

Table $24 \quad$ Multiple comparisons of membership of different organizations and perceived benefits (Anova test)

Table 25 The results of ordinal logistic regression 79

Table 26 Principles and criteria underlying ISCoffee... 89

Table 27 List of informants 95 
Chapter

Introduction 


\section{Introduction}

\subsection{Background}

Since the 1990s, smallholder producers of agricultural commodities in developing countries are increasingly confronted with private sustainability standards and certifications. Most of these standards are initiated by non-governmental organizations (NGOs) and businesses from the north, often in the form of a partnership between the two. Although participation in the schemes is voluntary, this has gradually become a prerequisite for access to parts of the global market (Brandi et al., 2013; Loconto \& Danker, 2014; Pierrot et al., 2010; Ponte, 2004). At the bottom of the value chain, smallholders need to make sense of these standards and the implications which result from them, and have to decide on how to react given their preferences and the socioeconomic opportunities that they have.

The coffee sector, which is the object of study in this dissertation, can be regarded as the pioneering industry for sustainability standards and certifications (Bitzer et al., 2008; Kolk, 2013; Pierrot et al., 2010; Reinecke et al., 2012). The development of global certifications began with the development of the so-called organic movement in 1939, followed by Fair Trade (FT) in 1988 and the Rainforest Alliance (RA) in 1991. A decade later, more certifications were introduced, including UTZ in 2002 and the Common Code of the Coffee Community or 4C in 2006 (Barry et al., 2012; KPMG, 2013). All these schemes prioritize different aspects of sustainable coffee production and generally focus on different types of producers. Fair Trade (FT), for example, concentrates on improving the social aspects of coffee production, whereas UTZ focuses on farm efficiency and coffee traceability (Auld, 2010; Reinecke et al., 2012). The Rainforest Alliance (RA) pays a lot of attention to environmental aspects (Kilian et al., 2004; Reinecke et al., 2012), while $4 \mathrm{C}$ - as a rather broad standard - emphasizes baseline criteria across all dimensions of sustainable development (Bitzer et al., 2008). All schemes focus on, and thereby certify, smallholder farmers. Some of them also include larger producers in their program (UTZ, RA), whereas FT only certifies smallholders. Notwithstanding differences in the emphasis of the schemes, the similarities in the way in which they are managed, and the similarities across the sustainability criteria that they adopt, cause significant overlap and competition among the schemes (KPMG, 2013; Reinecke et al., 2012).

Sustainability standards in coffee are defined as documented agreements containing specific criteria to be used consistently as rules, guidelines or definitions, to ensure that that coffee is grown, produced, traded, and processed with respect to social, economic, and environmental concerns (sustainability pillars); thereby have positive impacts on 
sustainable development. Certification is understood as a procedure by which a third party gives written assurance that a product and process is in conformity with sustainability standards, as the main instrument to govern agricultural production (Liu, 2003). Sustainability standards and certifications are driven by a theory of change which is based on the premise that a better training in agricultural practices, and a better organization of the farmers, may improve the quantity (i.e., volume) and quality (i.e., socially, environmentally, and economically) of production. It is assumed that a more sustainable production of coffee ultimately improves the livelihoods of smallholders (Blackman \& Rivera, 2011; Pierrot et al., 2010).

However, the impact of sustainability standards and certifications is still ambiguous and therefore widely debated. Some studies show that sustainability standards and certifications have positive impacts on smallholders such as enhancing market access, offering higher prices, and improving livelihood conditions. Certification processes are also said to have positive side effects, such as improving the quality and yields of coffee production in neighboring communities by allowing these to join community projects financed by certification premiums (Giovannucci \& Ponte, 2005). Other studies, however, indicate that the benefits of sustainability standards and certifications are rather limited. Economic benefits to smallholders are statistically significant but extremely small (i.e., 83.7-95.5\% of the economic rent are received by exporters or roasters), which is probably not enough to allow smallholders to improve their living conditions (Astuti et al., 2015). According to van Rijsbergen et al. (2016), smallholders only receive $6-8 \%$ of the consumer price. Moreover, certification may lead to higher costs, additional administrative tasks, and new dependency relations, which undermine part or all of the certification benefits (ITC, 2010; Neilson, 2008; Philpott et al., 2007). On a more general level, sustainability standards and certifications have come to be portrayed as marketing tools for traders in order to convince consumers to buy their products for a higher price. This trend of private certification will likely continue, as major corporations including Nestlé, Philip Morris/Kraft, and Sara Lee are becoming increasingly interested in private sustainability standards and certifications (Kolk, 2013).

The present dissertation aims to contribute to this debate in a specific way. It is observed that most research on sustainability standards and certifications takes a rather managerial approach, in the sense that it studies how the schemes unfold in practice and how their performance may be improved. By adopting such an approach, researchers implicitly accept the problem definitions of the schemes as set by their northern-based initiators. In this study, we focus on the problem perceptions of, and the reactions to, private certifications for Indonesian smallholder farmers. Although sustainability schemes can invent and monitor a multitude of sustainability standards and corresponding practices, it is ultimately not the schemes but rather the 
smallholders who need to be willing and able to change their practices, adopt the sustainability standards, and internalize them into their daily practices. For this reason, smallholders can be regarded as the "gatekeepers" of sustainability change in the Indonesian coffee sector. They are at the heart of the coffee production system and their practices determine whether the concept of sustainable coffee production will be implemented at the bottom of the value chain. The gatekeepers not only need to be the first to change, but their willingness and ability to change are also required to induce meaningful sustainability effects in the coffee chain as a whole.

In the Indonesian archipelago, coffee grows on almost all islands and is mostly cultivated by smallholders. The coffee sector is almost fully liberalized, which allows national and multinational traders to operate freely with only minimal involvement of the government. Coffee is not a strategic priority for the government, because it only accounts for less than 1\% of the total export revenues (BPS-Statistics Indonesia, 2017). The government seems to prefer to support commodities with a larger contribution to local or export taxes, such as palm oil ${ }^{1}$ (SCP, 2014) and rice. The main objective of this dissertation is to explore the barriers and opportunities that smallholders may encounter with regard to participation in sustainability standards and certifications, and to reflect on what this situation implies for a pathway to a more sustainable coffee production in Indonesia. This introductory chapter first prepares a profile of the Indonesian coffee smallholder, followed by a depiction of the characteristics of the Indonesian coffee sector, an overview of different certifications in the country, and a discussion on theoretical perspectives regarding sustainability standards, certifications, and the accompanying debates. Next, the research aims and research questions will be presented, followed by the scientific and policy relevance, the methodological approach, and an introduction to the concept of sustainability pathways.

\subsection{Profile of the Indonesian coffee smallholders}

The term "smallholder" is frequently used to describe rural producers, predominantly in developing countries, who use family labor and for whom the farm provides the principal source of income (Dixon et al., 2004; IFAD, 2009; World Bank, 2003). Further, smallholders are often characterized as farmers with a low-tech production system and a limited capacity for independent marketing, performing administrative tasks, and storing and processing their products. Farm size seems to be the most frequently used criterion to define smallholders, although the number used may differ across sectors

\footnotetext{
${ }^{1}$ In the beginning of 2017, Indonesian coffee exports reached 94.9 million US dollars, compared to palm-oil exports that reached 1,965.1 million US dollars - twenty times higher than coffee (BPS-Statistics Indonesia, 2017).
} 
and countries (Calcaterra, 2013; IFAD \& UNEP, 2013). The Indonesian ${ }^{2}$ and Indian government, for example, define smallholders as farmers who own plantations smaller than 25 hectares and 5 hectares, respectively (Government of India \& UNDP, 2004; Indonesian Ministry of Agriculture, 2006). The Malaysian ${ }^{3}$ government defines smallholders in general as farmers with plantations under 46 hectares, except in the rubber sector where smallholders' lands can reach up to 100 hectares (Malaysian Palm Oil Board, 2005; Malaysian Regulation, 1972). Meanwhile, multilateral organizations such as the World Bank, FAO, IFAD, and AfDB define smallholders as farmers with a farm size up to two hectares (Dixon et al., 2004; IFAD, 2009; Salami et al., 2010; World Bank, 2003). Although there is no agreement on the definition of smallholders, what matters most - in our study - is that smallholders can sustain their livelihoods through working in their own farms.

In Indonesia, smallholders manage more than 96\% of coffee plantations across the country and are likely to continue to do so, as estate plantations have declined significantly; there are only a few left on Java Island (Directorate General of Estate Crops, 2015). According to the Directorate General of Estate Crops $(2014 ; 2015)$ and BPS-Statistics Indonesia (2013), there are around 1.96 million coffee growing households across the country, amounting to around 5 million individuals who depend on coffee farming in Indonesia. ${ }^{4}$ Farmers who manage their coffee plantations on a more serious scale, however, only make up $25 \%$ of this number (SCP, 2014). On average, a smallholder household depends on 0.52 hectares of land, on which the family grows 942 coffee trees that produce 335.15 kilograms of coffee beans per year (BPS-Statistics Indonesia, 2013; SCP, 2014; Directorate General of Estate Crops, 2014). Smallholders' production costs on average constitute $68.9 \%$ of the farm gate price that they receive when selling their beans (Indonesian Ministry of Agriculture, 2016). The status of various Indonesian coffee smallholders, however, may differ considerably (see Table 1 below).

\footnotetext{
${ }^{2}$ In Indonesia, farmers are not considered smallholders if they have a plantation permit that is obligatory for any farmer with a farm size of more than 25 hectares (Indonesian Ministry of Agriculture, 2006).

${ }^{3}$ In Malaysia, to qualify as a smallholder and to be eligible for the associated benefits, farmers should be the lawful occupier of the land and can be disqualified if they are registered as private enterprises (Malaysian Regulation, 1972).

${ }^{4}$ Assuming that there are three dependents per household, coffee farming is likely to be a key livelihood source for more than five million individuals across the country.
} 
Table 1. Possible status of Indonesian smallholders

\begin{tabular}{|c|c|c|c|c|c|c|c|c|c|c|}
\hline Status & $\begin{array}{c}\text { Inde- } \\
\text { pendent }\end{array}$ & $\begin{array}{l}\text { Orga- } \\
\text { nized }\end{array}$ & $\begin{array}{l}\text { Certi- } \\
\text { fied }\end{array}$ & $\begin{array}{l}\text { Uncerti- } \\
\text { fied }\end{array}$ & Legal & Illegal & HKM & $\begin{array}{l}\text { Non- } \\
\text { HKM }\end{array}$ & $\begin{array}{l}\text { Ara- } \\
\text { bica }\end{array}$ & $\begin{array}{c}\text { Robus- } \\
\text { ta }\end{array}$ \\
\hline Independent & & & & $\mathrm{V}$ & $\bar{v}$ & V & & $\mathrm{V}$ & $\mathrm{V}$ & 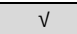 \\
\hline Organized & & & v & v & v & & v & v & v & v \\
\hline Certified & & v & & & v & & & v & v & v \\
\hline Uncertified & v & v & & & v & v & $v$ & $v$ & v & v \\
\hline Legal & v & v & v & v & & & v & $v$ & v & v \\
\hline Illegal & v & & & v & & & & v & v & v \\
\hline HKM & & v & & v & $v$ & & & & v & v \\
\hline Non-HKM & v & v & v & v & v & v & & & v & v \\
\hline Arabica & v & v & v & v & v & v & v & v & & \\
\hline Robusta & v & v & v & v & v & v & v & v & & \\
\hline
\end{tabular}

Source: Compiled by the author from various sources

Based on Table 1 above, Indonesian coffee smallholders can further be classified into four characteristics. First, based on organizational status, the farmers are categorized as independent or organized smallholders. Independent smallholders do not participate in any farmer organization and can therefore be considered unorganized. The majority of Indonesian coffee smallholders are believed to be unorganized (i.e., up to 75\%). ${ }^{5}$ These smallholders usually sell their coffee to local markets and commonly have a long-term connection with local traders or intermediaries. Joining a farmer organization has become de facto mandatory for smallholder participation in certification (Loconto \& Danker, 2014), implying that unorganized farmers are hardly able to participate in certification and obtain access to certified markets.

A second distinction is based on the presence of governmental licenses granting permission to cultivate coffee, including in protected forests. ${ }^{6}$ Without such permission, the smallholder's activities can be considered illegal. Illegal farmers cultivating coffee in forbidden, highly protected areas (e.g., preserved forests, wildlife sanctuaries) accordingly have no permission from the government. Legal farmers, who have such permission, consist of HKM and non-HKM farmers. HKM (hutan kawasan masyarakat, "community-based forestry management") refers to those farmers who are cultivating coffee in protected forests with government permission (i.e., a five-year extendable contract). Non-HKM farmers are located outside protected forest areas, with most formally owning their lands. Although HKM farmers are legalized by the government, they are not eligible to participate in sustainability standards and certifications because

\footnotetext{
${ }^{5}$ Estimate based on data and/or information provided by the Directorate General of Estate Crops (2014), BPS-Indonesia (2013), ICO (2017), and SCP (2014). No data were found that explicitly state the numbers of organized and independent coffee smallholders. Nationally, the percentage of unorganized smallholders (i.e., including farmers of all crops/commodities) is as high as $60.3 \%$ (BPS-Indonesia, 2013).

${ }^{6}$ Protected areas refer to all forest areas (including National Parks and Protected Forest) where any form of forest clearing is legally prohibited (Arifin, 2010).
} 
practicing in protected forests is not in line with the environmental concerns of the current (private) sustainability principles and criteria.

Third, based on participation in sustainability standards and certifications, the smallholders can be categorized as certified or uncertified smallholders. Table 1 above shows that certified farmers include only organized, legal (non-HKM) farmers. In contrast, uncertified farmers may include all types of farmers (i.e., legal and illegal, independent and organized, and HKM and non-HKM). Based on the available data, the majority of Indonesian smallholders (around 93\%) were uncertified in 2014 (SCP, 2014).

Fourth, smallholders can be categorized as Robusta or Arabica farmers, depending on the coffee species that they grow. There are no official data regarding the exact numbers of Robusta and Arabica smallholders; however, based on the data on production and land use (Directorate General of Estate Crops, 2014; 2015), up to 80\% of Indonesian coffee farmers grow Robusta varieties. Formally, we can distinguish additional coffee varieties in Indonesia such as Liberica and Excelsa, but these can be considered as relatively unimportant. Overall, this dissertation focuses on certified and uncertified smallholders. As sustainability and legal issues are related and cannot be separated, the uncertified farmers included in the analysis only refer to legal, non-HKM farmers. These smallholders were studied in Sumatra's coffee-producing provinces of Aceh and Lampung.

Overall, the Indonesian coffee smallholders are rather vulnerable because of small landholdings, relatively unstable incomes, and limited access to extension services (Arifin, 2010; SCP, 2014; Wahyudi \& Jati, 2012). The smallholders are also associated with poverty in rural areas, and limited access to both the market and proper healthcare (Arifin, 2017). As mentioned before, and partially due to their traditional cultivation methods, smallholders' productivity is rather limited and is estimated to be less than $60 \%$ of its potential (Wahyudi \& Jati, 2012). The quality of the harvest is also rather low, because of time pressure in peak seasons and the use of outdated processing methods and machinery (Arifin, 2010; de Wolf, 2013). These challenges are further aggravated by limited access to affordable credit, changing weather patterns (e.g., rainfall, temperature) that influence productivity, and the poor quality of infrastructure (e.g., delivery systems) that limit access to affordable inputs.

The smallholder supply chain can be differentiated in a supply chain of independent (unorganized) farmers and one of organized smallholders. In the unorganized smallholder supply chain, intermediaries such as village-level collectors and subdistrict or district traders play prominent roles (see Figure 1.a below). Coffee beans from thousands of farmers and of different quality are mixed; the traceability of coffee beans 
is therefore low by the time that the beans reach the intermediaries. Smallholders perform the initial processing (e.g., hulling the coffee cherries), but advanced processing (re-drying, cleaning, and sorting) is usually done by the intermediaries. This situation offers further financial advantages to intermediaries as such forms of processing improve the quality of the beans. In the organized smallholder supply chain, by contrast, farmer organizations generally take over the activities of re-drying, cleaning, and sorting that were previously handled by intermediaries (see Figure 1.b below). In this way, increased financial returns can be obtained by the organizations and their farmer members.

Figure 1. Supply chain models for organized and independent smallholder

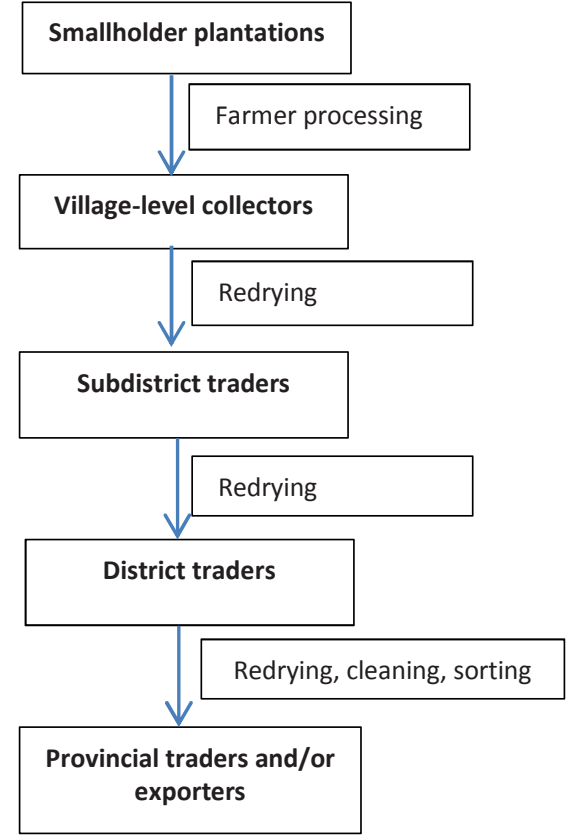

a

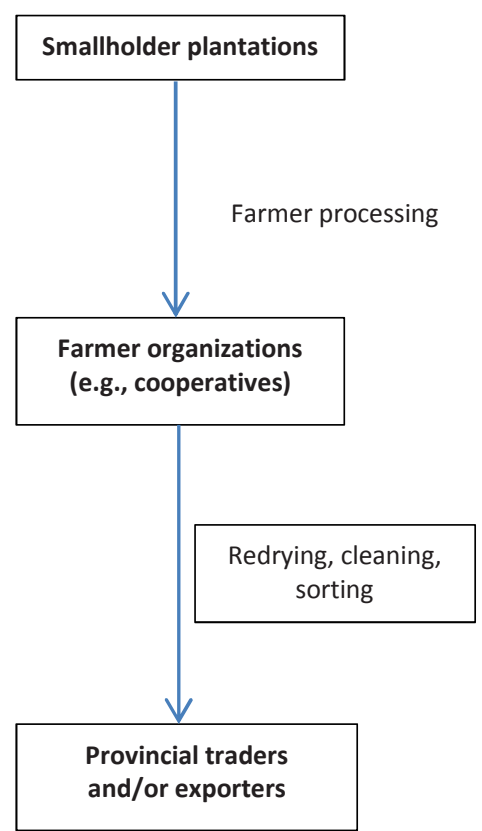

b

Source: Wahyudi \& Jati (2012) 


\subsection{The Indonesian coffee sector}

Indonesia is considered an important coffee producer in the world (i.e., it ranks fourth globally) with an average production of $613,874.6$ tons per year, or $7.22 \%$ of the world production (ICO, 2017). The majority of the coffee production $(63.27 \%)$ is exportable, meaning that production which is not consumed locally can theoretically be exported (see Table 2 below). In practice, however, export realization can differ from exportable production because of the time lag between production and export, which may for example be due to coffee collectors that hold on to the beans for some time waiting for better prices. In recent years, the average domestic consumption has also steadily increased and will potentially absorb a significant portion of the production in the future. The production increase is currently lower than the consumption and therefore the risk of declining supply is already present. This risk is caused by strong production fluctuations dependent on climate conditions, exacerbated by a decrease in productivity over time because of the aging of fecund coffee trees (Directorate General of Estate Crops, 2014; 2015).

Table 2. Coffee production and consumption in Indonesia $(* \Delta$ signifies changes compared to the previous year)

\begin{tabular}{ccccccccc}
\hline \multirow{2}{*}{ Crop year } & \multicolumn{2}{c}{ Production } & \multicolumn{2}{c}{ Exportable production } & \multicolumn{3}{c}{ Domestic consumption } \\
\cline { 2 - 8 } & Tons & $\Delta^{*}(\%)$ & Tons & $\%$ & $\Delta(\%)$ & Tons & $\%$ & $\Delta(\%)$ \\
\hline $2006 / 07$ & $448,960.4$ & -22.40 & $278,980.4$ & 62.14 & -43.21 & $169,980.0$ & 37.86 & 10.57 \\
$2007 / 08$ & $466,593.3$ & 3.78 & $266,613.3$ & 57.14 & -4.64 & $199,980.0$ & 42.86 & 5.00 \\
$2008 / 09$ & $576,740.8$ & 19.10 & $376,760.8$ & 65.33 & 29.24 & $199,980.0$ & 34.67 & -8.19 \\
$2009 / 10$ & $682,780,2$ & 15.53 & $482,800.2$ & 70.71 & 21.96 & $199,980.0$ & 29.29 & -5.39 \\
$2010 / 11$ & $547,764.1$ & -24.65 & $347,784.1$ & 63.49 & -38.82 & $199,980.0$ & 36.51 & 7.22 \\
$2011 / 12$ & $638,613.2$ & 14.23 & $418,593.2$ & 65.55 & 16.92 & $220,020.0$ & 34.45 & -2.06 \\
$2012 / 13$ & $691,112.3$ & 7.60 & $457,112.3$ & 66.14 & 8.43 & $234,000.0$ & 33.86 & -0.59 \\
$2013 / 14$ & $675,911.6$ & -2.25 & $425,891.7$ & 63.01 & -7.33 & $250,020.0$ & 36.99 & 3.13 \\
$2014 / 15$ & $685,096.6$ & 1.34 & $425,116.7$ & 62.05 & -0.18 & $259,980.0$ & 37.95 & 0.96 \\
$2015 / 16$ & $739,048.5$ & 7.30 & $469,048.5$ & 63.47 & 9.37 & $270,000.0$ & 36.53 & -1.41 \\
$2016 / 17$ & $600,000.0$ & -23.17 & $324,000.0$ & 54.00 & -44.77 & $276,000.0$ & 46.00 & 9.47 \\
\hline Average & $613,874.6$ & -0.33 & $388,427.4$ & 63.27 & -4.82 & $225,447.0$ & 36.73 & 1.70 \\
\hline
\end{tabular}

Source: Adapted from ICO (2017)

Indonesia exports coffee to countries in Europe, America, Asia, and Africa (see Table 3 below). While Europe and America are known as "old coffee markets," Asia, Africa, and some countries in the Pacific are considered to be "new coffee markets." For Indonesia, the old coffee markets had been the destination of coffee exports from the time of the colonial era (de Graaf, 1986). Since the 2000s, however, the new coffee markets have surpassed the old ones and have become the primary destination for Indonesian coffee exports (see Figure 2 below). These new export markets are typically less interested in sustainably certified coffee than the old markets (SCP, 2014; Wijaya \& Glasbergen, 2016). 
Table 3. Destination for Indonesian coffee exports (2006-2015)

\begin{tabular}{|c|c|c|c|c|c|c|c|c|c|c|}
\hline Year & 2006 & 2007 & 2008 & 2009 & 2010 & 2011 & 2012 & 2013 & 2014 & 2015 \\
\hline & Tons & Tons & Tons & Tons & Tons & Tons & Tons & Tons & Tons & Tons \\
\hline \multicolumn{11}{|l|}{$\begin{array}{l}\text { New } \\
\text { markets }\end{array}$} \\
\hline Japan & $67,012.3$ & $51,725.3$ & $52,992.2$ & $53,678.5$ & $59,170.9$ & $58,878.9$ & $51,438.4$ & $41,920.4$ & $41,234.3$ & $41,240.1$ \\
\hline Singapore & $14,558.1$ & $12,630.6$ & $7,237.0$ & $7,305.8$ & $6,079.0$ & $6,240.4$ & $9,154.1$ & $8,677.9$ & $7,725.9$ & $9,212.9$ \\
\hline Malaysia & $8,500.7$ & $12,407.5$ & $17,370.4$ & $17,803.2$ & $26,200.1$ & $26,382.1$ & $33,134.1$ & $40,580.4$ & $29,136.2$ & $38,347.5$ \\
\hline India & $11,172.7$ & $8,294.9$ & $12,085.0$ & $9,950.7$ & $9,733.3$ & $12,162.4$ & $19,884.0$ & $18,292.4$ & $14,434.3$ & $19,303.0$ \\
\hline Egypt & $11,721.7$ & $5,469.0$ & $10,109.0$ & $10,079.8$ & $12,024.7$ & $10,013.9$ & $17,594.6$ & $17,538.3$ & $15,694.6$ & $20,854.2$ \\
\hline Morocco & $7,627.2$ & $6,247.8$ & $6,860.4$ & $7,900.2$ & $8,369.1$ & $10,013.0$ & $11,268.6$ & $12,874.3$ & $10,418.7$ & $11,069.1$ \\
\hline Algeria & $14,073.0$ & $8,379.6$ & $23,205.6$ & $26,531.9$ & $10,303.2$ & $7,298.4$ & $10,488.9$ & $24,265.5$ & $10,590.6$ & $16,911.6$ \\
\hline Others & $72,979.1$ & $66,559.2$ & $123,602.8$ & $157,383.1$ & $111,693.8$ & $89,915.0$ & $117,529.6$ & $169,962.8$ & $102,460.8$ & $152,769.6$ \\
\hline $\begin{array}{l}\text { Total new } \\
\text { markets }\end{array}$ & $207,644.8$ & $171,713.9$ & $253,462.4$ & $290,633.2$ & $243,574.1$ & $220,904.1$ & $270,492.3$ & $334,112.0$ & $231,695.4$ & $309,708.0$ \\
\hline \multicolumn{11}{|l|}{$\begin{array}{l}\text { Old } \\
\text { markets }\end{array}$} \\
\hline USA & $85,503.2$ & $66,222.5$ & $65,646.0$ & $71,603.7$ & $63,048.0$ & $48,094.7$ & $69,651.6$ & $66,138.1$ & $58,308.5$ & $65,481.3$ \\
\hline UK & $12,245.8$ & $8,822.6$ & $15,125.3$ & $16,425.5$ & $24,343.1$ & $14,868.4$ & $16,312.4$ & $20,781.0$ & $14,349.2$ & $21,052.6$ \\
\hline Germany & $60,225.2$ & $43,074.1$ & $89,600.9$ & $78,876.0$ & $63,688.4$ & $26,461.0$ & $50,978.2$ & $60,418.5$ & $37,976.7$ & $47,662.4$ \\
\hline Italy & $27,635.5$ & $19,529.4$ & $30,213.4$ & $36,188.4$ & $26,770.7$ & $27,344.4$ & $29,080.8$ & $38,152.5$ & $29,745.5$ & $43,048.3$ \\
\hline Rumania & $8,743.9$ & $4,613.4$ & $4,565.9$ & $4,816.9$ & 2,219.4 & $1,497.0$ & $1,362.0$ & 507.6 & 397.9 & 492.6 \\
\hline Georgia & $9,510.3$ & $6,455.6$ & $9,238.4$ & $11,486.7$ & $9,077.4$ & $6,893.0$ & $9,133.5$ & $12,029.6$ & $10,277.1$ & $12,167.5$ \\
\hline $\begin{array}{l}\text { Total old } \\
\text { markets }\end{array}$ & $203,863.9$ & $148,717.6$ & $214,389.9$ & $219,397.2$ & $189,147.0$ & $125,158.5$ & $176,518.5$ & $198,027.3$ & $151,054.9$ & $189,904.7$ \\
\hline
\end{tabular}

Source: BPS-Statistics Indonesia (2016)

Figure 2. Export markets for Indonesian coffee

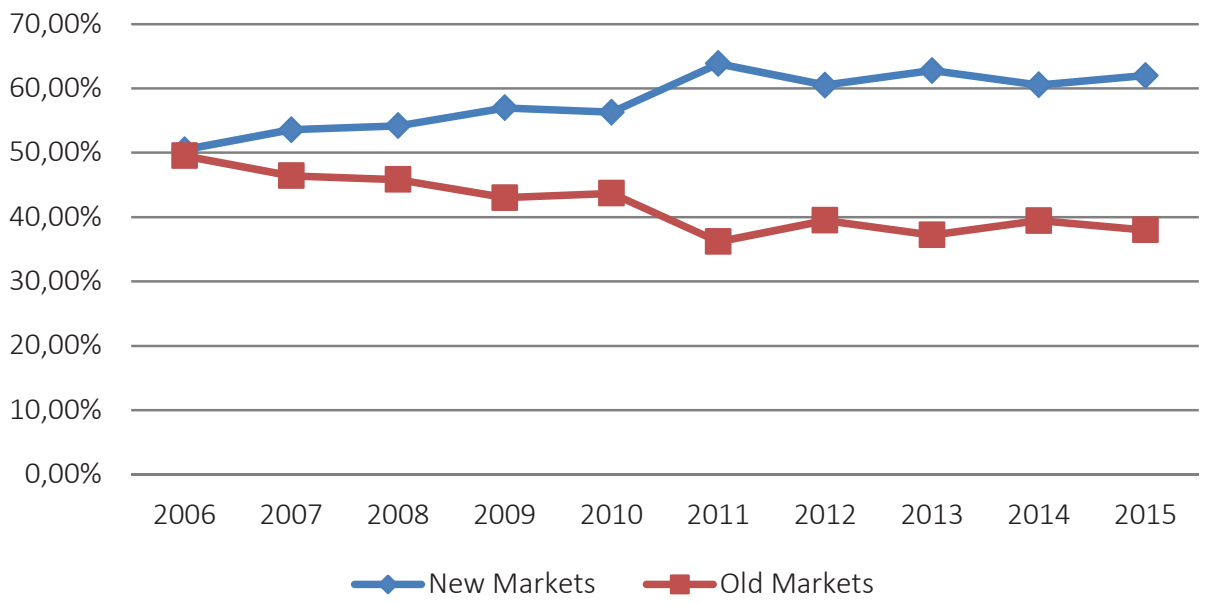

Source: BPS-Statistics Indonesia (2016)

Sumatra is the most significant coffee producing region in Indonesia (i.e., it contributes more than $70 \%$ to the national coffee production). Within Sumatra, significant coffee plantation areas are found in the provinces of Aceh (120,667 hectares) and Lampung $(155,007$ hectares), which together make up $25 \%$ of the national Arabica production and $23.6 \%$ of the national Robusta production, respectively (Directorate General of Estate Crops, 2014). Table 4 below provides an overview of the areas where this coffee 
is grown and the processing techniques that are most commonly adopted. Arabica coffee shrubs need to be grown at an altitude of 1,000-1,500 meters above sea level with temperatures around $16-20^{\circ} \mathrm{C}$. These conditions can only be fulfilled at mountain ranges and on volcanic slopes (Arifin, 2017). Most of the mountain ranges and volcanic slopes are, however, part of highly protected forests, which means that Arabica plantations are difficult to extend when compared to the Robusta plantations at lower altitudes. Arabica coffee is generally favored by northern consumers because of its mild flavor and relatively low caffeine content. Indonesian Arabica is furthermore renowned as a high-quality coffee - also known as specialty coffee ${ }^{7}$ - and is promoted because of its taste (Wahyudi \& Jati, 2012). ${ }^{8}$ Markets for specialty coffee are relatively stable, its consumers are comparatively loyal (Neilson, 2014), and prices paid for Arabica are generally higher than for Robusta (Coffee Review, 2013).

Table 4. Coffee produced in the provinces of Aceh and Lampung, Sumatra

\begin{tabular}{|c|c|c|}
\hline & Arabica Gayo & Robusta Lampung \\
\hline $\begin{array}{l}\text { Geographical } \\
\text { area }\end{array}$ & $\begin{array}{l}\text { - Gayo Highland, Central } \\
\text { Aceh (northern Sumatra) } \\
\text { 1,000-1,500 m altitude, } \\
\text { fertile volcanic soil, wet } \\
\text { climate }\end{array}$ & 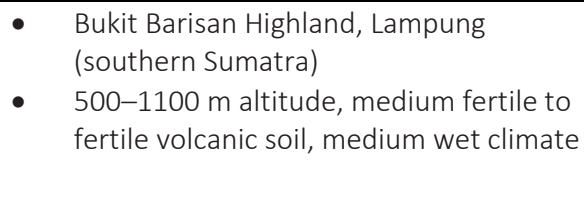 \\
\hline $\begin{array}{l}\text { Type of } \\
\text { processing }\end{array}$ & $\begin{array}{l}\text { - Mostly wet processing and } \\
\text { wet hulling/wet processing } \\
\text { Mostly organic farming } \\
\text { systems under shade }\end{array}$ & $\begin{array}{l}\text { - } \\
\text { - } \text { processing }^{9} \\
\text { Inorganic and organic farming systems, } \\
\text { medium shade tree application, } \\
\text { integrated farming }\end{array}$ \\
\hline
\end{tabular}

Sources: de Wolf (2013); Directorate General of Estate Crops (2014)

The majority of the coffee produced in Indonesia (up to 75\%) is, however, Robusta (Ministry of Agriculture, 2016). The dominance of Robusta coffee results from the availability of plantation areas and from the fact that Robusta is generally preferred by Indonesian coffee producers, because it is sturdy, it grows well, and it is relatively resilient to diseases and pests (de Graaf, 1986; Coffee Review, 2013). Indonesia is currently the world's second largest Robusta producer and exporter (see Figure 3 below), although the Indonesian Robusta is generally sold in bulk with little or no qualitative differentiation from Robusta produced by other countries across the market

\footnotetext{
${ }^{7}$ Some producer countries have benefited from the specialty market by branding local quality coffee and successfully developing a name and niche market (Slob, 2006).

${ }^{8}$ Some places are renowned for producing high quality Arabica coffee with an exceptional good taste, such as Gayo coffee, Toraja coffee, Mandheling coffee, Flores coffee, Lintong coffee, and Kintamani coffee.

${ }^{9}$ In a dry processing method coffee cherries are processed after the fruit is dried, whereas in a wet processing method cherries are processed while the fruit is still wet and fermented.
} 


\section{Chapter 1}

(Neilson, 2014). The implication is that the market tends to go for Robusta - regardless of where it comes from - at the lowest price.

Figure 3. The fifteen most significant Robusta producers in the world

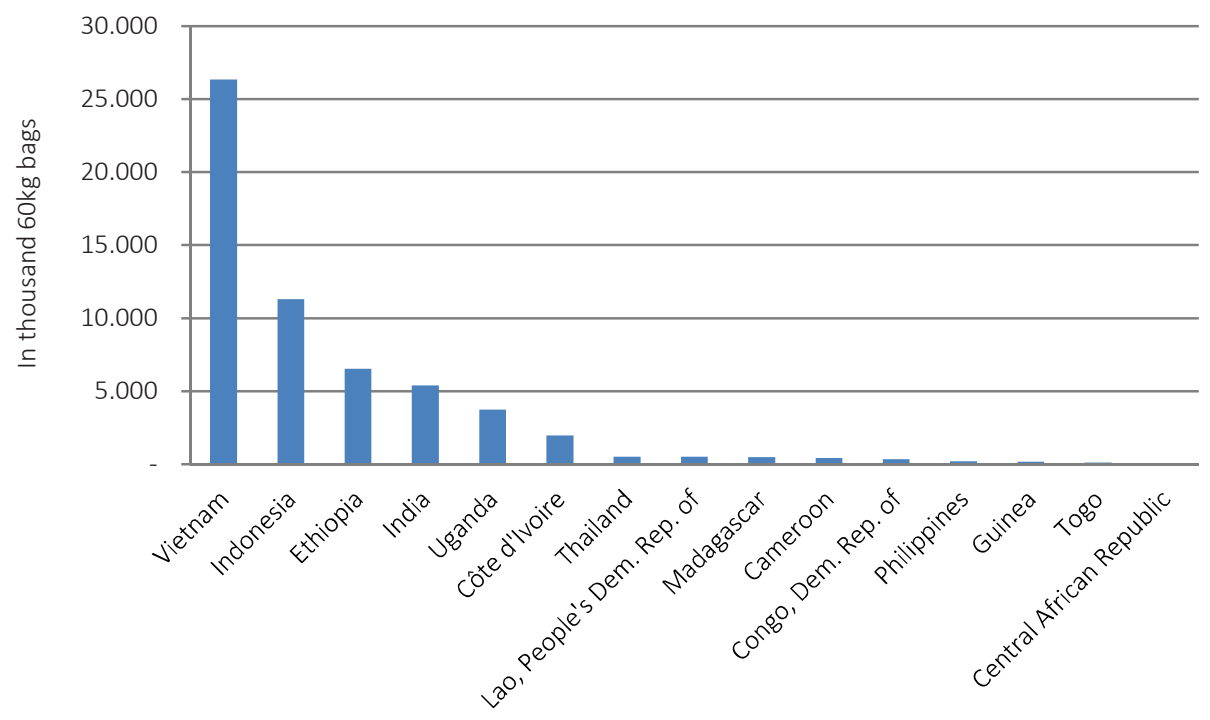

Source: ICO (2017)

The Indonesian coffee sector is not devoid of problems. With concerns over low farm yields and high transaction costs, as well as the current trend of growing domestic consumption, Indonesia will likely become a net Robusta importer within 10 years (SCP, 2014). There is, however, the potential to increase farmers' yields and to maintain a fairly low cost base (SCP, 2014). In Indonesia, the costs are relatively low because most farmers make limited use of fertilizers (Wahyudi \& Jati, 2012; Directorate General of Estate Crops, 2015), which also limits the productivity and consequently the yields. As the Indonesian coffee production has not yet reached its full capacity, an investment here could lead to a higher yield than in other countries such as Uganda and Vietnam (SCP, 2014). Without exported coffee from Indonesia, a substantial supply gap may come to threaten the international coffee industry. As a result, supply may increasingly depend on Robusta plantations in Vietnam, which now faces environmental challenges (SCP, 2014).

Some initiatives to increase the coffee production have been taken by the government, mainly through rejuvenating old coffee trees and expanding coffee plantation areas. Increasing the total production is not only essential to better use Indonesia's potential in the production of coffee, but also to keep up with increasing consumer demands for 
coffee. According to SCP (2014), global Robusta demand is projected to increase by 1530 million bags (i.e., 900,000-1,800,000 tons) ${ }^{10}$ per year over the next 10 years (until 2024/25). The government is therefore attempting to increase the total Indonesian coffee production to $900,000-1,200,000$ tons per year, or by at least $50 \%$ in 2025 (Directorate General of Estate Crops, 2015). Given the average annual growth in coffee plantation areas (see Table 5 below), it remains to be seen whether the coffee sector can realize this target of a $50 \%$ increase in total production. Even though many initiatives to increase the total volume of coffee production have been initiated by the Indonesian government, these initiatives have to be taken up and implemented by smallholders. This process implies that efforts to increase coffee production cannot be seen separately from attempts to enhance the capacities of the smallholders who produce the coffee.

Table 5. The development of coffee plantation areas in Indonesia, in hectares

\begin{tabular}{lllllll}
\hline Year & 2010 & 2011 & 2012 & 2013 & 2014 & Average growth (\%) \\
Hectares & $1,210,365$ & $1,233,698$ & $1,235,290$ & $1,241,712$ & $1,246,810$ & 0.75 \\
\hline
\end{tabular}

Source: Directorate General of Estate Crops (2015)

\subsection{The world of certifications in Indonesia}

The smallholders are nowadays confronted with different types of certifications, which differ in scope and history. In Indonesia, RA started in Aceh Province in 1993, followed by FT in the same province in 1997. UTZ became involved in the coffee sector in 2002, followed by 4C in 2006 (see Table 6 below). RA aims to support farmers in creating more sustainable livelihoods, improving farm productivity, and becoming more resilient to climate change. RA certification consequently concentrates on how farms are managed, with certification being awarded to farms that meet the standards of the Sustainable Agriculture Network (SAN). FT focuses on realizing a better life for farming families in the developing world through direct trade, community development, environmental stewardship, and guaranteed prices for their products. To further support farmers' economic development, FT requires the first coffee buyers to provide pre-financing for and long-term contracts with farmers (FT, 2017). UTZ works to create transparency along the supply chain and reward responsible coffee producers (UTZ, 2017), whereas 4C aims to achieve global leadership as a baseline initiative that enhances economic, social, and environmental production, processing, and trading conditions for all actors who make a living in the coffee sector (GCP, 2017).

${ }^{10}$ One bag is equal to 60 kilograms or 132.276 pounds of coffee (ICO, 2017). 
Table 6. Comparison of sustainability standards and certification in Indonesia

\begin{tabular}{|c|c|c|c|c|}
\hline Programs & RA & FT & UTZ & $4 C$ \\
\hline $\begin{array}{l}\text { Starting year in } \\
\text { Indonesia }\end{array}$ & 1993 & 1997 & 2002 & 2006 \\
\hline $\begin{array}{l}\text { Regions of } \\
\text { operation }\end{array}$ & $\begin{array}{l}\text { Aceh, Lampung, } \\
\text { south Sumatra }\end{array}$ & Aceh & Lampung, Aceh & $\begin{array}{l}\text { Lampung, south } \\
\text { Sumatra }\end{array}$ \\
\hline Coffee variety & Robusta, Arabica & Arabica, Robusta & Robusta, Arabica & Robusta \\
\hline Main focus & Sustainability & Fairness & Sustainability & Sustainability \\
\hline Standards & $\begin{array}{l}\text { Minimum } \\
\text { compliance } \\
\text { threshold }\end{array}$ & $\begin{array}{l}\text { Minimum and } \\
\text { progress compliance }^{11}\end{array}$ & $\begin{array}{l}\text { Minimum } \\
\text { compliance threshold }\end{array}$ & $\begin{array}{l}\text { Baseline common code } \\
\text { criteria }\end{array}$ \\
\hline Verification & $\begin{array}{l}\text { Third-party } \\
\text { auditors }\end{array}$ & $\begin{array}{l}\text { Flo-Cert, third-party } \\
\text { auditors }\end{array}$ & Third-party auditors & Third-party auditors \\
\hline $\begin{array}{l}\text { Code elements } \\
\text { for coffee } \\
\text { production }\end{array}$ & $\begin{array}{l}\text { Best management } \\
\text { practices; } \\
\text { conservation of } \\
\text { natural resources, } \\
\text { ecosystems, and } \\
\text { wildlife; workers' } \\
\text { rights and } \\
\text { benefits; benefits } \\
\text { to local } \\
\text { communities }\end{array}$ & $\begin{array}{l}\text { Social, economic, } \\
\text { environmental, and } \\
\text { democratic } \\
\text { organization of } \\
\text { cooperatives }\end{array}$ & $\begin{array}{l}\text { Socially, } \\
\text { environmentally, and } \\
\text { economically } \\
\text { conscious growing } \\
\text { standards; food } \\
\text { safety and quality } \\
\text { elements }\end{array}$ & $\begin{array}{l}\text { Exclude worst practices } \\
\text { and continuously } \\
\text { increase the } \\
\text { sustainability of coffee } \\
\text { production and } \\
\text { processing in the } \\
\text { economic, social, and } \\
\text { environmental } \\
\text { dimension }\end{array}$ \\
\hline Market focus & $\begin{array}{l}\text { Mainstream } \\
\text { market }\end{array}$ & Mainstream market & Mainstream market & Mainstream market \\
\hline Pricing system & Market price & Minimum price floor & Market price & Market price \\
\hline Credit financing & $\begin{array}{l}\text { Through local } \\
\text { banks }\end{array}$ & $\begin{array}{l}\text { Pre-financing (up to } \\
50 \% \text { of value) }\end{array}$ & Unspecified & Unspecified \\
\hline $\begin{array}{l}\text { Technical } \\
\text { assistance/ } \\
\text { capacity } \\
\text { building }\end{array}$ & $\begin{array}{l}\text { Provided by local } \\
\text { NGO partners } \\
\text { (Sustainable } \\
\text { Agriculture } \\
\text { Network); training } \\
\text { of extension } \\
\text { workers (by the } \\
\text { program and/or } \\
\text { by collaborating } \\
\text { institutions) }\end{array}$ & $\begin{array}{l}\text { Provided by TransFair } \\
\text { USA for specific } \\
\text { projects through its } \\
\text { Global Producer } \\
\text { Services department, } \\
\text { and by FLO (Fairtrade } \\
\text { Labelling } \\
\text { Organizations } \\
\text { International) } \\
\text { worldwide through its } \\
\text { Producer Business } \\
\text { Unit }\end{array}$ & $\begin{array}{l}\text { Provided by the } \\
\text { program at very low } \\
\text { cost to producers in } \\
\text { alliance with other } \\
\text { initiatives like the } \\
\text { Coffee Support } \\
\text { Network (CSN) }\end{array}$ & $\begin{array}{l}\text { Support to } 4 \text { C Units, } \\
\text { members and other } \\
\text { interested stakeholders } \\
\text { through training-of- } \\
\text { trainer workshops, } \\
\text { educational sessions, } \\
\text { and access to } \\
\text { tools/manuals; } \\
\text { cooperation with other } \\
\text { national/international } \\
\text { organizations, and } \\
\text { between } 4 C \text { members }\end{array}$ \\
\hline Target groups & $\begin{array}{l}\text { Smallholders and } \\
\text { professional } \\
\text { farms }\end{array}$ & Smallholders & $\begin{array}{l}\text { Smallholders and } \\
\text { professional farms }\end{array}$ & $\begin{array}{l}\text { Smallholders and } \\
\text { professional farms }\end{array}$ \\
\hline $\begin{array}{l}\text { Traceability/ } \\
\text { chain of custody }\end{array}$ & $\begin{array}{l}\text { Traceable from } \\
\text { roaster to } \\
\text { producer }\end{array}$ & $\begin{array}{l}\text { Traceable from roaster } \\
\text { to producer }\end{array}$ & $\begin{array}{l}\text { Traceable from } \\
\text { roaster to producer }\end{array}$ & $\begin{array}{l}\text { Traceable from } 4 C \text { Unit } \\
\text { to producer }\end{array}$ \\
\hline $\begin{array}{l}\text { Gender equity } \\
\text { and youth rights }\end{array}$ & $\begin{array}{l}\text { Equal rights and } \\
\text { exclusion of child } \\
\text { labor }\end{array}$ & $\begin{array}{l}\text { Equal rights and } \\
\text { exclusion of child labor }\end{array}$ & $\begin{array}{l}\text { Equal rights and } \\
\text { exclusion of child } \\
\text { labor }\end{array}$ & $\begin{array}{l}\text { Equal rights and } \\
\text { exclusion of child labor }\end{array}$ \\
\hline
\end{tabular}

Sources: Arifin (2010); Arifin et al. (forthcoming); FT (2017); GCP (2017); KPMG (2013); RA (2017); SCAA (2010); UTZ (2017)

${ }^{11}$ Minimum compliance represents minimum practices in social empowerment, economic development, and environmental responsibility to be met prior to initial certification. Progress criteria are fulfilled after the first year of certification, representing continuous development toward increased social, economic, and environmental responsibilities. 
RA, FT, and UTZ are regarded to be more stringent than $4 \mathrm{C}$, which uses baseline criteria for famers to comply with a basic level of sustainability. Farmers may subsequently use the baseline criteria as stepping stones to participate in the more demanding schemes (Fransen, 2015). Regarding pricing, most schemes implement a market-based pricing system except for FT, which adopts a minimum price floor. In Indonesia, RA, 4C, and UTZ are present in Aceh, Lampung, and south Sumatra, but FT is - up to now - only present in Aceh. A similarity between all schemes is that they promote themselves as voluntary standards and certifications, ${ }^{12}$ and believe in the urgent need to transform agricultural practices into more sustainable practices. They also share the belief that certification through credible systems may help to induce and realize this transformation. All schemes target and reach smallholders through farmer organizations (e.g., farmer groups and cooperatives), and prescribe producer rights (e.g., representation rights). These farmer organizations are also responsible for organizing trainings to guarantee that farmers fulfill the criteria to become certified. The role of farmer organizations in certification is therefore of vital importance. Smallholders do not hold certificates themselves, but these are either held by farmer organizations (e.g., cooperatives) or by so-called "first buyers" (i.e. traders/exporters or roasters). To date, international traders and/or exporters are the principal investors in sustainability programs in the country (Neilson, 2008; 2014; SCP, 2014). In 2014, 7\% of the exported coffee from Indonesia was certified (SCP, 2014), which is a relatively small percentage of the total production.

Besides the mainstream global certification schemes, locally based certifications also exist in Indonesia. Examples are Inofice (Indonesian Organic Farming Certification) which certifies coffee and agricultural products based on SNI organic criteria, ${ }^{13}$ the certificate of geographical indication (GI), and ISCoffee (Indonesian Standard Coffee). The $\mathrm{Gl}$ is considered to be an intellectual property right, regulated by the national law on brands (UU RI No 15, 2001). This certificate aims to formally assure that certain agricultural commodities originate from particular geographical environments, thereby providing assurance to consumers that the products are native and specific to a region. Regarding ISCoffee, this certification was initiated by the Indonesian Ministry of Agriculture. It will likely be the first public sustainability standard and certification for coffee in the country (Media Perkebunan, 2013), though up to now it has not yet been formally implemented.

\footnotetext{
${ }^{12}$ Voluntary standards are usually verified through third-party auditing and have a higher degree of transparency and participation of affected stakeholders than, for example, private standards developed and monitored internally by individual enterprises (Ponte, 2004).

${ }^{13} \mathrm{SNI}$ is a national standard set by the Indonesian National Standardization Agency, specifying the classification, the labelling, and the packaging of green coffee beans (PP RI No. 102, 2000).
} 


\subsection{The debate on sustainability standards and certifications}

Studies of sustainability standards and certifications, particularly in the coffee sector, can be classified into at least five categories. The first strand of literature evaluates the impacts of sustainability standards and coffee certification on smallholders' livelihoods and welfare, environmental conditions, and social aspects. The results of these studies vary as to the observed impacts, from positive to modest and limited or even negative. Studies that found positive impacts claim that certification increases smallholders' income through higher prices and improved productivity and quality (Arnould et al., 2009; Bacon, 2005). Joining a certification program also improves the security of land tenure and education, enhances infrastructural assets and opportunities for monetary investments, and enhances the access to clean water (Bacon, 2005; Bacon et al., 2008; Barbosa de Lima et al., 2009). Other studies are more cautious, arguing that the economic benefits of certification are "very modest" or "fairly modest". These studies assert that certification may lead to statistically significant improvements in income, but that the difference between the income of certified and uncertified farmers is very small. Remarkably, and contrary to studies by for example Arnould et al. (2009) and Bacon (2005), Valkila (2009) argues that certification reduces productivity (Valkila, 2009). In addition, some scholars state that the lack of a real price difference between certified and uncertified coffee is to blame for detaining certified farmers from higher net benefits (Ruben \& Forth, 2012). Studies that found limited impacts claim that not all schemes are suitable for smallholders, since price premiums seem to be too small to compensate for smallholders' additional efforts to comply with environmental and social requirements (Kilian et al., 2004). Finally, studies reporting negative effects argue that certification imply additional costs, as it is doubted whether smallholders can cover these higher farming costs (Beuchelt \& Zeller, 2011; Calo \& Wise, 2005; Lyngbaek et al., 2001).

The second strand of literature concerns the legitimacy of sustainability standards and certifications (see for example Bernstein, 2011; Bernstein \& Cashore, 2007; Cashore, 2002; Glasbergen, 2013; Raynolds, Murray, \& Heller, 2007). In this strand, two main themes shape the literature. First, general reflections are offered on the legitimacy of private actors' activities versus public policies by state authorities. The issue is that nonstate standard setters and stakeholders within a certification network may not be authorized by legitimate state authorities. Nonetheless, their roles are expanding and they promote themselves as responsible actors in the coffee value chain (Giovannucci \& Ponte, 2005, on coffee; Tallontire, 2007, on forestry). The question is whether the legitimate state authorities agree on the norm-based criteria proposed by private standards and certifications (Bernstein, 2011, on cocoa, coffee, sugar, forestry, and fishery certification), and whether the private arrangements create tensions with the 
existing, state-centered authority and public policymaking processes (Cashore, 2002, on forestry). Second, we find literature in which authors more generally reflect on the mainstreaming of certification schemes. The issue addressed in this strand is how certification can be mainstreamed in the coffee sector of developing countries, given the broad and diverse organizational structures inherent to the coffee sector in those countries (due to differences in history and politics, production management, and coffee portfolios in their economy). Related questions concentrate on how internal legitimacy ${ }^{14}$ of sustainability standards and certification can be regarded as external acceptance of the rule system in the relevant market (Glasbergen, 2013, on palm oil, tea, and fair labor), how sustainability standards and certifications deal with tensions at the producer level (Getz \& Shreck, 2006, on coffee), and how they can achieve their legitimacy democratically (Raynolds et al., 2007, on coffee). Another query considers how certifications realize their legitimacy in the mainstream market for sustainable coffee while confronting this "wicked" problem (Kolk, 2013) ${ }^{15}$ and being criticized as a "race to the bottom" (Reinecke et al., 2012). ${ }^{16}$

The third strand of literature focuses on the distribution of power in the coffee value chain in relation to institutional changes brought about by sustainability standards and certifications. The concepts of global value chains (GVC) and partnerships are frequently used in this literature strand. From a GVC perspective, studies addressing trends in power inequalities among key actors (Kaplinsky, 2004) argue that farmers, local traders, and governments in producing countries are increasingly marginalized, especially since the deregulation and liberalization of the coffee sector as from the 1990s (Calo \& Wise, 2005; CFC, 2000). The literature also claims that the liberalization process has resulted in a concentration of power in the hands of multinational corporations acting as coffee traders and roasters (Clay, 2004; de Graaf, 1986; Kaplinski, 2004; TCC, 2012). These giant companies shape the coffee chain structures through their ability to govern producers' access to final consumers (Kaplinsky, 2004), which further illustrates the role of global private regulation ${ }^{17}$ in the coffee sector (Neilson \& Pritchard, 2009). From a partnership perspective, an institutionalized platform is created for collaboration between coffee farmers, companies, and other actors such as NGOs and civil society

\footnotetext{
${ }^{14}$ Internal legitimacy refers to consensus among formal participants involved in the process of establishing certification (Glasbergen, 2013).

${ }^{15}$ A problem characterized by complexities (interdependencies, multicausalities, divergent perceptions, and a multitude of stakeholders), dynamics, and unintended outcomes (Kolk, 2013).

${ }^{16}$ A reflection of the competition of sustainability standards and certifications schemes as legitimate standards and certifications that address the aspects of coffee production at a smallholder level (Reinecke et al., 2012).

${ }^{17}$ Global private regulation refers to the enforcement of rules and standards on upstream producers by downstream private sector actors (Neilson \& Pritchard, 2009).
} 
groups. This institutional platform is an important initiator of change in the smallholder coffee system (Bitzer et al., 2008), providing more value for smallholders (Muradian \& Pelupessy, 2005) and enhancing their ability to comply with market entry requirements and diverging standards (Vellema et al., 2012). Topics for further exploration include the kinds of institutional arrangements that are most promising in order to address complex, multilayered, and multiscalar sustainability issues (Glasbergen, 2007), and how to maintain equity, transparency, and a balance of power among actors (Giovannucci \& Ponte, 2005; Ponte, 2002).

The fourth strand of literature considers the ability of smallholders to compete in the export value chain of agricultural commodities. On the one hand, sustainability standards and certification are considered key barriers for smallholders to enter the global market. The root of this problem is identified as the farmers' underdeveloped competences (knowledge, skills) and financial, organizational, and institutional capacity to comply with the certification requirements (M4P, 2008:11; Neilson, 2008; Weber, 2007). Producers with low proficiencies are unable to adapt to market changes and perceive market requirements simply as barriers. On the other hand, Jaffee (2003) and van Tulder et al. (2004) argue that barriers induced by sustainability standards and certification are worth it for competent actors; their profits may grow as barriers increase. In addition, sustainability standards and certification provide significant opportunities for smallholders because they reduce the length of the coffee chain (Lee et al., 2012).

The fifth and final strand of literature studies the recent emergence of sustainability standards and certifications initiated by southern actors in developing countries. According to Schouten \& Bitzer (2015), public standards and certifications including ISPO (Indonesian Sustainable Palm Oil), ISCoffee (Indonesian Standard Coffee), and ISCocoa (Indonesian Standard Cocoa) can be considered a response from southern actors in developing countries to establish counter initiatives to the northern-based standards and certifications. An explanation is provided by Smith \& Fischlein (2010), who argue that these counter initiatives emerge because certain groups of stakeholders in the south are dissatisfied with or feel disadvantaged by the outcomes of the northern standards and certifications. Another explanation is provided by Wijaya \& Glasbergen (2016), who claim that counter initiatives emerge because southern governments consider it their responsibility to regulate agricultural sectors and to assert their nation's identity through national standards and certifications. Some points for discussion in this literature strand are whether states will take responsibility for system change, whether states can avoid problems in the enforcement of sustainability rules and regulations (Glasbergen \& Schouten, 2015), and whether southern-based standards 
and certifications can gain international recognition to enhance their global market share (Giovannucci et al., 2014; Schouten \& Bitzer, 2015).

\subsection{Research aims and research questions}

Based on this literature review, we argue that smallholders are perceived in most studies as objects of change. This dissertation, in contrast, takes a bottom-up approach by placing the smallholders at the center of the study. Smallholders operate in a complex system characterized by strong interrelations between agricultural and nonagricultural decisions, and between food and non-food requirements. Smallholders also have their own preferences and needs, which inform their actions with regard to production, marketing, and participation in certification. They are often driven by conflicting objectives, such as a decision to be fully dedicated to farming activities versus a choice to pursue non-farming activities. In line with these considerations, this dissertation has three objectives.

The first aim is to examine the position of smallholders as gatekeepers of sustainability. From the global value chain (GVC) perspective, external pressures from actors (e.g., coffee collectors/traders, wholesalers, retailers, consumers, etc.) greatly influence the position of smallholders in the coffee value chain. Studies that use the GVC perspective mostly conclude that smallholders have the weakest bargaining position in the supply chain. This dissertation, however, argues that smallholders are also influenced by social relationships within and between households. These relationships include interactions within farmer organizations, which further profoundly affect their preferences, perceptions, motivations, and values. These specific local contexts at a smallholder level can, conversely, be considered as internal forces that influence smallholders' strategic positions. The GVC perspective largely fails to comprehensively understand these internal forces, as the value appropriation (from a smallholder point of view) within the coffee chain is mostly ignored. Against this background, the first objective of this dissertation is to examine the position of smallholders as gatekeepers of sustainability embedded in the interplay between internal and external forces.

The second objective is to assess smallholders' interpretations of the process of value creation through sustainability standards and certifications. On the one hand, based on the GVC perspective, sustainability standards and certifications themselves can be considered as an external force because they are imposed on smallholders by other value chain actors - for example, by coffee traders. Numerous studies implicitly take this perspective to evaluate the impact of sustainability standards and certifications on, for instance, smallholders' livelihoods, welfare, and access to the market. From the GVC perspective, sustainability standards and certifications have therefore been extensively 
studied. On the other hand, sustainability standards and certification may, when properly implemented at the farmer level, be internalized by farmers and create value for them. However, little attention has so far has been paid to this internalization process (from the farmers' point of view), and consequently little explanation can be provided by relevant literature. The second objective of the dissertation is therefore to assess smallholders' interpretation of the process of value creation as driven by sustainability standards and certification. Value creation refers to benefits and the process of creating benefits, which can be tangible (e.g., income, contract, or services) and intangible (reputation, a feeling of social belonging, etc.). In other words, the second objective is to understand how smallholders view sustainability standards and certifications, and what attributes they attach to livelihood improvements as a consequence of participating in sustainability practices and certifications.

The third aim, which is considered as the main objective, is to explore the implications of the research results for a more sustainable coffee production. Given the key issues shaping smallholders' involvement in certification, this objective entails an exploration of barriers and opportunities that smallholders perceive vis-à-vis their participation in sustainability standards and certifications, and the reflection on what this perception implies for the pathway to a more sustainable coffee production.

These research objectives have been translated into the following research questions:

What values do farmers attach to sustainability standards and certifications? How and to what extent do these values correspond to the intervention logic of sustainability certification? What does this valuation imply for the process toward a more sustainable coffee production in Indonesia?

Four individual research projects address specific subthemes, which together aim to answer the main research questions.

i. What are Indonesian smallholders' preferences regarding coffee certification schemes, and what are the characteristics of the scheme most preferred by them?

Chapter 2 aims to answer this question by investigating the preferences of Indonesian coffee smallholders for certification attributes. Most coffee certification schemes are developed by northern-based businesses and NGOs to regulate the production of coffee in the south. It is questionable whether these northern-driven standards correspond to the preferences of coffee farmers in the south. Understanding farmer preferences and taking them into account when developing or improving certification schemes is believed to lead to more internalized and therefore more effective standards. However, 
there is a lack of information on farmer's preferences, both in the academic literature and in the certification programs themselves. Based on conjoint analysis and interviews, this chapter investigates the preferences of smallholder coffee farmers in Indonesia. Conjoint analysis is a multivariate technique that is useful to examine tradeoffs made by individual respondents when facing a range of options (Green et al., 1999). A total of 210 smallholders are surveyed in the Tanggamus and West Lampung Districts of Lampung Province, including farmers registered with global certification schemes (i.e., RA, UTZ, and 4C), a local certification scheme (Inofice), and uncertified coffee producers. The quantitative software SPSS (Statistical Package for the Social Sciences) was used for the conjoint analysis.

\section{ii. How can smallholder participation in certifications be explained?}

Chapter 3 aims to answer this question by assessing the relative importance of various explanations for farmer participation in certifications. The literature provides four competing explanations: sociodemographic, economic, attitudinal, and institutional. However, little is known about the relative importance of these explanations. Knowledge of the relative importance is believed to lead to a more effective implementation of standards and inclusion of smallholders. Up to now, researchers provide different explanations for participation; this chapter aims to contribute to the literature by bringing some order to the current explanations. To assess the importance of the explanations mentioned in the literature, questionnaire data were collected from Indonesian coffee smallholders in the producing provinces of Aceh and Lampung, including 160 coffee farmers certified with global certification schemes (i.e., RA, FT, UTZ, and 4C) and uncertified farmers. The data were first processed in Microsoft Excel and subsequently analyzed with the quantitative software Stata. The method of analysis was Heckman selection model with a two-step procedure. This model offers a framework for correcting non-randomly selected samples and allows correcting for selection bias (Bushway, Johnson, \& Slocum, 2007; Marchenko \& Genton, 2012).

iii. What are the different forms of farmer organizations and how do they relate to certification? How do differences in perceived benefits relate to the membership of different organizations and certification schemes? What do these findings imply for a more sustainable coffee production from a smallholders' point of view?

Chapter 4 aims to answer these questions by analyzing different types of farmer organizations in the Indonesian coffee sector. Both certification and participation in farmer organizations are associated with economic and social benefits to farmers. However, there is limited knowledge of the potential differences in perceived benefits 
that result from participating in the different forms of organization and certification schemes. In this chapter, three types of farmer organizations in the Indonesian coffee sector are distinguished: farmer groups, cooperatives, and KUBEs. The perceived benefits to farmers (including unorganized farmers) from these different forms of organization are compared, as well as the benefits resulting from participation in different certification schemes (i.e., FT, UTZ, RA, and 4C). We surveyed 160 coffee smallholders in the provinces of Aceh and Lampung. The statistical analyses applied were ordinal logistic regression to predict outcomes (i.e., perceived benefits) based on membership in an organization and/or participation in certification, and the Anova (analysis of variance) and t-test to analyze differences among respondent groups.

iv. What are barriers and opportunities in the process of implementing ISCoffee? What contribution could its implementation make to address generic problems in the coffee sector? Will this public regulation become an alternative to private certifications?

Chapter 5 aims to answer these questions by analyzing the implementation capacity of ISCoffee for as a public standard and certification initiated by the Indonesian government. The chapter specifically contributes to the literature on the emerging trend of southern-based sustainability standards and certifications, which are perceived as a reaction to the northern-based private standards by businesses and NGOs. A qualitative analysis was applied and the primary data were gathered through interviews. Respondents were selected based on convenience and snowball sampling approaches. In addition to the interviews, we analyzed a variety of written materials (printed and online), including scientific articles, published and unpublished documents from governmental and non-governmental institutions, news-articles from Indonesian media and magazines as well as presentation materials from a roundtable workshop on coffee in Indonesia.

\subsection{Relevance to science and policy}

Studies on private sustainability standards and certifications mainly use a macro-level perspective, enabling them to suggest improvements to certification trajectories from the perspective of the northern-based initiators of the schemes while at the same time advancing certification theory. However, an advanced certification theory may not be a panacea for smallholders' problems. This dissertation argues that the realities with which smallholders are confronted in their daily practices, as well as their interpretation of the process of value creation through sustainability standards and certifications, is a gap of knowledge that needs to be filled. Therefore, we particularly aim to add to the knowledge on what it really means to comply with the social, economic, and 
environmental aspects of sustainability standards and certifications from a smallholder perspective. Our focus on real-life aspects of this rather new trend of sustainability requirements in coffee production also contributes to the knowledge of drivers and barriers for certification compliance by smallholders. As a result of this emphasis on smallholders in their economic, social, and environmental settings, the dissertation simultaneously uses micro-level analyses and a bottom-up perspective to produce empirical yet scientific knowledge on a more sustainable coffee production. This dissertation specifically enriches the literature by studying a southern perspective, with a particular focus on Indonesian contexts, and by examining the position of coffee smallholders as gatekeepers of sustainable coffee production.

Moving away from a traditional coffee production system to a more sustainable one requires knowledge, planning, and resources for investment. Research mainly contributes to the first aspect, whereas policymakers and relevant stakeholders are responsible for the other elements. Efforts to empower and facilitate smallholder inclusion in sustainable value chains are, however, rarely backed by sufficient planning and resources. Most governments, for example, offer limited support and extension services to smallholders. While these factors can be seen as the consequences of weak planning and limited resources, they can also be attributed to the implementation of ineffective policy in the coffee sector. This dissertation, by contrast, does not aim to produce knowledge of policy; instead, it focuses on developing knowledge that is useful in policy and/or program designing processes. Such knowledge is important to lead the natural and human resources of the coffee sector into a sustainable direction. To develop policies and/or programs that can have a sustainable impact on the smallholder coffee farming system, policymakers and relevant stakeholders in the sector need to refine their understanding of smallholders' realities. Such a consideration may enhance their sensitivity in, for instance, the complex institutional drivers of farmer behavior (e.g., side-selling, encroachment on protected areas, and land use change) and tradeoffs (between local conservation priorities and economic realities) that smallholders face. This direction may further contribute to more customized policies and standards, based on a bottom-up approach and bundled with a systemic perspective, than are available at present.

\subsection{Research approach: challenges in our fieldwork}

Our research approach is mainly inspired by the work of agricultural scientists who study farm crops and the factors affecting farm production to improve the efficiency and sustainability of the farm. The perspective of the agricultural scientist is therefore taken into account in this research, on the assumption that agricultural scientists seek to maintain a balance between, for instance, farmers' economic interests and 
socioenvironmental concerns. This assumption furthermore leads to a mixed research approach by combining positivist and constructivist methodologies. The former adheres to the view that knowledge is gained through observation and measurement, as a result of which a researcher needs to rely on an objective approach that leads to observable and quantifiable findings. By contrast, the latter holds that a researcher needs to understand the context or situation of participants (in this case, the farmers) and should be able to explain the collected data or patterns emerging from, for example, communication and/or interaction with the farmers (Moses \& Knutsen, 2012). Most of the data that we used in the dissertation are consequently primary data, collected through surveys and interviews with smallholders.

Although smallholders were almost always willing to cooperate, collecting data was found to be a challenging process. The first challenge relates to smallholders' understanding of concepts and terms used by sustainability standards and certifications. Many smallholders have a limited understanding of sustainability concepts, although they may have applied these in practice. Smallholders often understand certifications as belonging internally and naturally to the activities that they already undertake in farmer groups. Though they know what to do through training, they do not fully understand the essence of certification (i.e., improving the sustainability of coffee production). Many smallholders are even unaware that they participate in a certification scheme. Some steps were therefore necessary to guarantee that smallholders understood the questions. First, discussions with farmer organizations (especially the leaders of farmer groups) were conducted to obtain information regarding, for example, the organizations, their smallholder members, and their potential participation in certification. Group leaders are usually knowledgeable smallholders who know the ins and outs of their groups better than the other members. Second, trial questionnaires were randomly presented to smallholders to evaluate whether they could understand the questions. If smallholders did not understand any questions, these were revised and subsequently presented to them anew. The questionnaires were only finalized after the smallholders could understand the questions. Third, to make sure that smallholders answered the questions in the manner in which they were instructed, they were assisted in answering a number of questions, after which they could answer the remaining questions independently.

The second challenge regarding our fieldwork relates to smallholders' openness to provide information. Some information was rather difficult to obtain through structured data collection instruments, particularly on relatively sensitive topics. For example, whether certified or uncertified smallholders still sell their coffee to intermediaries or whether they are active inside protected forests is a rather delicate question, because most smallholders know that such an activity is discouraged (or even prohibited) by 
certification. Smallholders may tend to avoid answering the questions or hide the facts. To address this risk, sensitive questions were not asked immediately, but only when interviewers seemed to have gained the confidence and trust of the smallholders. It is therefore important to make smallholders feel comfortable; for example, by inviting the farmers to informal discussions in order to share personal stories or experiences before starting interviews or surveys.

The third challenge refers to a situation in which smallholders seem keen on "looking good" or "acting smart" in front of the interviewer (by pretending that they understand the questions) or, conversely, when they try to remain "modest" and/or "safe" by choosing mostly middle (neutral) scores. To address this issue, the interviewer clearly communicated to smallholders that the goal of the survey was not to get to the "correct" answers. Rather, the goal was to find "real" or "honest" answers for the development of knowledge, so that they should not be afraid to answer. The interviewer also conducted trials to see whether farmers chose too many middle scores (i.e., poor data distribution) and whether the measurement scale confused the farmers (i.e., questionnaires on a Likert scale). Based on the trials, the risk of obtaining a poor data distribution was low and a five-point Likert scale was found to be the most suitable for the surveys.

\subsection{Sustainable pathways}

Proponents of certification regard compliance with standards' principle and criteria as the pathway to sustainability in coffee production (Giovannucci \& Ponte, 2005; Milder et al., 2015; Raynolds et al., 2007). This view, however, is open to the criticism that compliance with the principles and criteria of the standards does not necessarily benefits smallholders (Ibanez \& Blackman, 2016; van der Vossen, 2005; van Rijsbergen et al., 2016). In other words, the criticizers implicitly claim that sustainability standards and certifications might not necessarily be the best pathway for a more sustainable coffee production because of their limited benefits to smallholders. These contrasting views further imply that a sustainable pathway for coffee production should accommodate and harmonize two important elements: sustainability (i.e., compliance with sustainability principles and criteria) and inclusiveness (i.e., benefits to smallholders). Coffee production in Indonesia consequently needs to be operationalized in both a sustainable and an inclusive way.

Producing coffee in a sustainable way requires production to comply with sustainability principles and criteria; for example, improved productivity and quality without using more land or contributing to deforestation. The implication is that farmers should have better access to professional farming packages - including improved farming inputs, 
knowledge, skills, and negotiating power - and better markets. Producing coffee in an inclusive way entails benefits to smallholders such as improved welfare and enhanced livelihood conditions. These improvements in turn will motivate them to stay in the coffee business and be productive, while at the same time attracting younger generations to the sector. In our study, we mainly explore the meaning and content of inclusiveness from a farmers' point of view, identifying discrepancies between the current situation and a sustainable future. The combination of the notions of sustainability and inclusiveness in the last chapter of the dissertation leads to a systematic view of a sustainable pathway that may guide the Indonesian coffee sector from the current situation toward a more sustainable future. 


\section{Chapter}

\section{Farmer preferences for coffee certification: a conjoint analysis of Indonesian smallholders}

This chapter is based on:

Ibnu, M., Glasbergen, P., Offermans, A., \& Arifin, B. (2015). Farmer Preferences for Coffee Certification: A Conjoint Analysis of the Indonesian Smallholders. Journal of Agricultural Science, 7(6). doi: 10.5539/jas.v7n6p20. 


\subsection{Introduction}

Sustainability certification has been introduced as new governance model since the mid-1990s and regulates food production in Southern countries (Glasbergen, 2013). Global certification programs address sustainability issues through using social, economic, and environmental indicators as the basis of their standards. Combined with certification rules and codes of conduct, these global sustainability standards function as 'non-state regulations' that govern food supply chains (Arifin, 2010; Auld, 2010). Regarding coffee certification there are numerous global certification schemes, including Rainforest alliance, UTZ certified, 4C, Organic, Fairtrade, and Smithsonian Bird Friendly. Next to these global, voluntary and private certification initiatives we can also distinguish local certification schemes (e.g. Inofice certification in Indonesia) and public certifications schemes (e.g. ISCoffee, which was initiated by the Indonesian Ministry of Agriculture in 2013). All these standards have in common that they attempt to cover the entire value chain from farmer to consumer (Giovannucci \& Ponte, 2005) and that their impacts on farmer's livelihoods are heavily debated.

Many empirical studies have been conducted to analyze the impact of certification. Results however, often seem to be contradictory (Beuchelt \& Zeller, 2011), misleading (Chiputwa et al., 2015) and fluctuate between attributing positive effects to certification (see for example Barbosa de Lima et al., 2009; Becchetti and Costantino, 2008; Rueda and Lambin, 2013), towards attributing insignificant benefits (Bitzer et al., 2008; Holzapfel \& Wollni, 2014; Jena et al., 2012; Méndez et al., 2010; Philpott et al., 2007; Valkila, 2009), and even attributing negative consequences on livelihoods due to certification (for example Beuchelt \& Zeller, 2011; Getz \& Shreck, 2006; UttingChamorro, 2005). Our literature review also shows that most empirical studies that evaluate the impact of the sustainability standards are conducted in Africa and in Latin America (e.g. Arnould et al., 2009; Bacon et al., 2008; Bechetti \& Costantino, 2008; Bitzer et al., 2013; Méndez et al., 2010; Philpott et al., 2007; Ruben \& Zuniga, 2011; Ruben \& Fort, 2012; Valkila, 2009). Papers about the impact of certification on Indonesian farmers are extremely rare although Indonesia is the fourth largest coffee exporter in the world, and even the second world's largest exporter of Robusta coffee (ICO, 2017).

Notwithstanding this reputation as Robusta exporter, only $25 \%$ of the certified Indonesian coffee covers Robusta coffee. The majority (75\%) of certified coffee is Arabica. Organic, as a global certification scheme, was among the first schemes in the Indonesian (Arabica) coffee sector; it has been implemented in Aceh in the 1990s (Arifin, 2008) and still covers the majority of certified, exported coffee from Indonesia (Wahyudi \& Jati, 2012). Currently, many more global certification schemes certify coffee in Indonesia. Besides the global certification schemes, we can distinguish local schemes 
Farmer preferences for coffee certification: a conjoint analysis of the Indonesian smallholders

that are either initiated by the Indonesian government (ISCoffee) or initiated by other actors like farming agencies (Inofice). The Indonesian Standard Coffee certificate (ISCoffee) was initiated by the Indonesian Ministry of Agriculture and implemented by the government (Media Perkebunan, 2013, March 12). In the future, the government may require that Indonesian coffee producers are certified according to the national standard. According to Mawardi (2014), Neilson (2014), and Sughandi (2014) the formulation of ISCoffee was not only triggered by the existence of global certification schemes, but also by the increase in domestic coffee consumption and emerging export markets, particularly the markets in Africa and Asia. In 2013, 56\% of the total Indonesian coffee export was targeted at these newly emerging markets and the Indonesian government wants to attach a "national identity" to the new coffee markets in the form of local (or national) certification (Sughandi, 2014). Other local certification schemes that were not initiated by the Indonesian government have been established in Indonesia as well. For example, the Inofice standard, managed by the Indonesian Organic Farming Infection and Certification Agency encompasses an organic certification scheme which refers to the National Standard of Indonesia or Standar Nasional Indonesia (SNI). It certifies plants and plant products (e.g. food, horticulture, crop and plantation), and livestock and livestock products (e.g. milk, egg, meat and honey) (Inofice, 2007).

The global coffee certification schemes that are present in Indonesia are developed by, and based on, the preferences of Northern consumers and implemented through multinational roasting companies and/or exporting firms (Neilson, 2008, 2014). According to Wahyudi \& Jati (2012), the Indonesian farmers' participation in the global certifications is mainly the result of the buyers' requirements rather than the farmers' interest. Reliable data on the smallholder farmers' preferences for coffee certification programs in Indonesia are currently not available. Several studies suggest that understanding farmer's preferences is vitally important to target a certification program effectively (Birol et al., 2009), to design more acceptable programs (Bekele, 2006), to choose the right strategies for improving farmers' productivity and income (BaiduForson et al., 1997), and to improve the pertinence of the programs (Raghavarao et al., 2011). Certification schemes, however, pay little to no attention to the role of farmer preferences in the formulation and adoption stage of standards. Perhaps as a consequence, most of these programs reach their intended goals only partially (see Adesina \& Baidu-Forson, 1995; Bekele, 2006).

This paper is based on the premise that standard setting organizations, in order to be (more) acceptable to farmers, should consider farmer preferences. If certification schemes do not correspond to farmer's preferences, they may not be dedicated to 
comply with the certification principles, and some may even not be willing to participate. The objective of this paper is to contribute to our knowledge about smallholder preferences regarding coffee certification in Indonesia. The main research question is: What are Indonesian smallholders' preferences regarding coffee certification schemes, and what characteristics does the most preferred scheme according to their opinion - contain? Field work was conducted in the province of Lampung, one of the major Robusta coffee producing regions in Indonesia (Arifin, 2010; Wahyudi \& Jati, 2012).

This study contributes to previous studies in two ways. First, it examines the preferences for coffee certification from a southern producers' perspective, and from an Indonesian perspective in particular. The number of Indonesian smallholders are large (i.e., around 1.96 million coffee-growing households) (BPS-statistics Indonesia, 2013), and they can potentially make a significant contribution to sustainable coffee produced by Southern countries. Second, the study includes and compares the preferences of smallholders participating in global certification schemes (Utz certified, Rainforest Alliance, and 4C), a local certification scheme (Inofice), and smallholders who do not participate in any certification programs. In the next sections we describe our methods (conjoint analysis and qualitative interviews) and provide an overview of our respondents. In section three and four we present our results and in section five our conclusions and reflection can be found.

\subsection{Methods}

The literature distinguishes several methods to operationalize and measure preferences. With the hedonic regression method the items being researched are decomposed into their essential characteristics to obtain estimates on the influence of each characteristic (Reis \& Santos Silva, 2006). Q-sort methodology focuses on understanding subjective phenomena and respondents arrange or sort a set of previously determined statements (Bracken \& Fischel, 2006). The contingent-valuation or willingness-to-pay procedure, in its simplest form, determines the respondents' willingness to pay for hypothetical actions with specified characteristics (Carson \& Flores, 2000; Bridges et al., 2007). For our study it is important that farmer's preferences can be related to (potential) characteristics of a (most preferred) certification scheme and that we can compare any differences in preferences between locally, globally and non-certified farmers. To that end, we decided to use conjoint analysis to evaluate farmer preferences regarding the most preferred certification scheme. 
Farmer preferences for coffee certification: a conjoint analysis of the Indonesian smallholders

\section{Conjoint analysis}

Conjoint analysis is a powerful and robust method for understanding farmer preferences (Arifin et al., 2009; Tano et al., 2003). It is a multivariate technique that is useful to examine trade-offs made by individual respondents when they are facing a range of options (Green et al., 1999). Conjoint analysis encompasses several iterative steps of (re)defining and verifying so called attributes, interpretations (or attribute levels) and profiles. An attribute is a characteristic inherent to the variable that will be measured; in our case coffee certification schemes (see column 1 in Table 7 below). Attributes can be interpreted in different ways, depending on the farmer's preferences. These different interpretations are the attribute levels (see column 2-4 in Table 7). As recommended by Green et al. (1999) and Walley et al., (1999) attributes and interpretations were selected by reading the codes of conduct containing core principles and guidelines of several coffee certification schemes (Fairtrade, Utz certified, Rainforest Alliance and 4C). Differences between existing schemes are expressed by differences between attribute levels (see Table 7). In addition, if existing schemes do not vary (enough) for specific attributes, the researcher has the freedom to add attribute levels (for example fairness as focus criteria). The different attribute levels can be combined in different ways into a certification scheme. These different combinations are profiles (see appendix 1). The attribute levels in Table 7 result in $2^{7} \times 3^{1}=384$ possible profile combinations.

These profiles describe certification alternatives (or scenarios) (Green et al., 1999). According to Bakken \& Frazier (2006), researchers recommend that the maximum number of profiles is 15 to 20 per respondent. If respondents must evaluate too many profiles, they tend to simplify their assessment process which distorts their true preferences (Green et al., 1999). In addition to the high cost of administering the survey, farmers' misperception and exhaustion can also be overwhelming, and the probabilities of farmers disregarding some attributes are high (Arifin et al., 2009). To this end, we had to reduce the possible profiles from 384 to a maximum of 20. SPSS contains a powerful procedure to select possible profiles randomly: the Generate Orthogonal Design Procedure, which offered 16 full profiles (see Appendix 1). The profiles were written in Bahasa Indonesia, and pre-tested at the study sites. The pretests revealed that the smallholders have more difficulty in ordering choices (ranking) than rating. Rating (i.e. indicating the desirability of each profile separately) and ranking (i.e. ranking the different profiles from most- to least desirable) provide similar results in terms of preferences (Boyle et al., 2001; Haefele \& Loomis, 1999). 
Chapter 2

Table 7. The final list of attributes and attribute levels of certification programs

\begin{tabular}{|c|c|c|c|c|}
\hline \multirow{2}{*}{\multicolumn{2}{|c|}{ Attributes }} & \multicolumn{3}{|c|}{ Attribute Levels } \\
\hline & & \multirow{2}{*}{$\begin{array}{ll}1 \\
\text { Yes }\end{array}$} & \multirow{2}{*}{$\begin{array}{ll}2 \\
\text { No }\end{array}$} & \multirow[t]{2}{*}{3} \\
\hline 1. & Price Premium & & & \\
\hline 2. & Certification target & $\begin{array}{l}\text { Smallholder Farmer } \\
\text { in farmer group or } \\
\text { cooperative }\end{array}$ & Large estates & \\
\hline 3. & Environmental Focus & $\begin{array}{l}\text { Close to } \\
\text { environmental } \\
\text { conservation }\end{array}$ & $\begin{array}{l}\text { Biodiversity, soil } \\
\text { fertility, agro- } \\
\text { ecology }\end{array}$ & $\begin{array}{l}\text { Close to } \\
\text { organic } \\
\text { input }\end{array}$ \\
\hline 4. & Marketing Schemes & $\begin{array}{l}\text { Contract between } \\
\text { producers and } \\
\text { buyers }\end{array}$ & No contract & \\
\hline 5. & Important goal & $\begin{array}{l}\text { Fairness (through } \\
\text { democracy, } \\
\text { participation and } \\
\text { transparency) }\end{array}$ & $\begin{array}{l}\text { Sustainability } \\
\text { (through good } \\
\text { farm management) }\end{array}$ & \\
\hline 6. & Credit option & Yes, Pre-finance & $\begin{array}{l}\text { No pre-finance, } \\
\text { only cash payment } \\
\text { at transaction } \\
\text { stage }\end{array}$ & \\
\hline 7. & $\begin{array}{l}\text { Price differential between } \\
\text { certified and uncertified } \\
\text { coffee (especially when } \\
\text { local market prices } \\
\text { increase) }\end{array}$ & Yes & No & \\
\hline 8. & $\begin{array}{l}\text { Price differential based on } \\
\text { the sizes of coffee beans. }\end{array}$ & Yes & No & \\
\hline
\end{tabular}

However, based on confidence interval tests, rating provides more information and is relatively more efficient than ranking (Mackenzie, 1993). Rating of each profile is therefore used in the surveys with a scale of 1 to 5 , in which 1 represents the least desirability and 5 the highest desirability. Rating based on full-profile conjoint analysis (i.e. full-profile plans by using orthogonal design) has the advantage that it utilizes fractional factorial designs that allows researchers to conduct statistical tests without evaluating all possible combinations of the attributes and the attributes levels (IBM Corp., 2010; Bakken \& Frazier, 2006; Green et al., 1999). The results of our conjoint analysis are utility (part-worth) scores and percentages that indicate the relative importance of each attribute level (see Table 10 below). Similar to regression coefficients, the part-worth scores provide a quantitative degree of preferences for each attribute level, and the larger values correspond to the greater preferences. The relative importance of an attribute indicates how important the attribute is to the overall preference (IBM Corp., 2010). If all attributes would be considered equally important, they would all have a score of $100 / 8$ attributes $=12.5 \%$. 
Farmer preferences for coffee certification: a conjoint analysis of the Indonesian smallholders

Important in conjoint analysis, and recommended by many (e.g. Arifin et al., 2009; Walley et al., 1999; Harrison et al, 1998) is pre-testing and verification of the attributes and attributes levels. To guarantee reliability and validity, it is important that the selected attributes and (variances in) attribute levels are understood by the farmers, cover the full range of farmer's preferences, and are easily digestible to rate. To this end, we went through four cycles of testing and verifying the attributes and attribute levels with farmers by conducting interview and organizing focus group discussions with the farmers. These cycles ultimately resulted in the reduction of attributes from 16 to 8 , and a reduction in attribute levels from 4 to 3 . The initial list with attributes and attribute levels can be found in Appendix 2. Reasons to reduce attribute levels include that the farmers perceived "biodiversity, soil fertility, agro-ecology" equal to "soil fertility, erosion resilience". Therefore, only "biodiversity, soil fertility, agro-ecology" is used as one of the attribute levels. Similarly, the farmers considered that the price premium levels "no, but market price" and "no, but negotiated between seller and buyer" are just the same. To the smallholders, both levels have the same meaning: "no price premium." Therefore, we only differentiate between the presence and absence of a price premium in our final list of attributes (see Table 7 above). The list does not cover social criteria (e.g. labor issues) because the farmers argued in the pre-tests that criteria related to forced labor, child labor and discrimination are irrelevant to their farming practices as they only own small plantations (1-2 hectares), which they can easily harvest and maintain on their own. Besides, they hardly hire labor, which makes minimum wages also irrelevant to the farmers. The pre-test thus already indicated that the most preferred certification scheme - in the eyes of the smallholder farmers - does not prioritize social issues.

After the conjoint analysis, we interviewed 15 farmers. The goal of these interviews was twofold: first to verify the results from the conjoint analysis and second to gain more information about the argumentation behind the preferences. The latter offered relevant results on why farmers have specific preferences and why some preferences differed for the different farmer groups.

\section{Respondent selection and characteristics}

Previous conjoint studies vary widely in terms of the number of respondents (sample sizes) used, although 120 seems to be a typical number (Walley et al., 1999; Weiner, 1994). Our research covers 210 respondents, yielding 16 (the number of full profiles, see annex 1) × 210= 3360 observations. By randomly surveying farmers from the different sub-districts and villages, we collected the data of 35 coffee farmers from each of the schemes and from uncertified producers. The sample size has met the minimum 
number of required respondents to ensure the study design orthogonal (each combination of attribute levels has the same theoretical chance to appear). According to Arifin et al. (2009), in order to be orthogonal the number of respondents must be proportional to the number of profiles. This means the minimum number of required respondents in our study equals the total amount of possible profiles (384) divided by the number of full profiles (16), which are 24. The research was conducted in the Tanggamus Regency and in the West Lampung Regency of Lampung Province, Indonesia from October 2013 until February 2014. They are known as coffee producing regions where the farmers mainly cultivate Robusta coffee. The farmers are certified with Rainforest Alliance, Utz certified, 4C, and Inofice. The Fairtrade standard and other certifications that mainly certify Arabica farmers are not present in these regions. Competition among the schemes in the regions is low; only one scheme is present in each village. Rainforest Alliance and $4 \mathrm{C}$ mainly certify the smallholders in Tanggamus, whereas the Utz standard certifies the farmers in West Lampung. Inofice certification is only found in West Lampung with a limited number of farmer participants. On average, around $70 \%$ of the farmers in the researched districts turned out to be uncertified. The details of the sample are shown in Table 8 below.

Table 8. Respondent types, location of interviews and the number of respondents

\begin{tabular}{|c|c|c|c|c|}
\hline \multirow[b]{2}{*}{ Respondent Groups } & \multicolumn{3}{|c|}{ Survey Location } & \multirow{2}{*}{$\begin{array}{l}\text { Number of } \\
\text { Respondents }\end{array}$} \\
\hline & Regency & Sub District & Village & \\
\hline 4C certified farmers & Tanggamus & Air Naningan & Way Harong & 35 \\
\hline \multirow[t]{2}{*}{$\begin{array}{l}\text { Rainforest certified } \\
\text { farmers }\end{array}$} & Tanggamus & $\begin{array}{l}\text { Pulau } \\
\text { Panggung }\end{array}$ & Tanjung Rejo & 20 \\
\hline & Tanggamus & $\begin{array}{l}\text { Pulau } \\
\text { Panggung }\end{array}$ & Way Ilahan & 15 \\
\hline Utz certified farmers & $\begin{array}{l}\text { West Lampung } \\
\text { West Lampung }\end{array}$ & $\begin{array}{l}\text { Sumber Jaya } \\
\text { Sumber Jaya }\end{array}$ & $\begin{array}{l}\text { Tugusari } \\
\text { Kebun Tebu }\end{array}$ & $\begin{array}{l}24 \\
11\end{array}$ \\
\hline Inofice certified farmers & West Lampung & Way Tenong & $\begin{array}{l}\text { Gunung } \\
\text { Terang }\end{array}$ & 35 \\
\hline \multirow[t]{2}{*}{ Uncertified farmers } & Tanggamus & $\begin{array}{l}\text { Pulau } \\
\text { Panggung }\end{array}$ & Kemuning & 35 \\
\hline & West Lampung & Sumberjaya & Sukapura & 35 \\
\hline Total Respondents & & & & 210 \\
\hline
\end{tabular}

According to Arifin et al. (2009) and Setiawan et al., (2012), respondent characteristics such as age, years of education, migration, ethnicity, and household assets - have little effect on preferences and perceptions. Nonetheless, we performed a One-way Anova test to compare the demographic characteristics of our respondent groups which indicated that the respondents are similar in terms of education, years of working as coffee farmers, and landholding (see Table 9 below). 
Farmer preferences for coffee certification: a conjoint analysis of the Indonesian smallholders

Table 9. The results of means comparison with One-way Anova

\begin{tabular}{|c|c|c|c|c|c|c|}
\hline & & \multicolumn{5}{|c|}{ ANOVA } \\
\hline & & $\begin{array}{l}\text { Sum of } \\
\text { Squares }\end{array}$ & $\mathrm{df}$ & Mean Square & $\mathrm{F}$ & Sig. \\
\hline \multirow[t]{3}{*}{ Age } & Between Groups & 1422.214 & 5 & 284.443 & 3.335 & .006 \\
\hline & Within Groups & 17401.714 & 204 & 85.303 & & \\
\hline & Total & 18823.929 & 209 & & & \\
\hline \multirow[t]{3}{*}{ Education } & Between Groups & 31.886 & 5 & 6.377 & .493 & .781 \\
\hline & Within Groups & 2636.229 & 204 & 12.923 & & \\
\hline & Total & 2668.114 & 209 & & & \\
\hline \multirow{3}{*}{$\begin{array}{l}\text { Time length of becoming coffee } \\
\text { farmers }\end{array}$} & Between Groups & 510.310 & 5 & 102.062 & 1.417 & .220 \\
\hline & Within Groups & 14698.171 & 204 & 72.050 & & \\
\hline & Total & 15208.481 & 209 & & & \\
\hline \multirow[t]{3}{*}{ Land ownership } & Between Groups & 29.613 & 5 & 5.923 & 1.813 & .112 \\
\hline & Within Groups & 666.256 & 204 & 3.266 & & \\
\hline & Total & 695.868 & 209 & & & \\
\hline \multirow[t]{3}{*}{ Productivity } & Between Groups & 8330687.490 & 5 & 1666137.498 & 22.278 & .000 \\
\hline & Within Groups & 15257049.354 & 204 & 74789.458 & & \\
\hline & Total & 23587736.844 & 209 & & & \\
\hline
\end{tabular}

The test shows that the average of ages varies among respondent groups, but the Post Hoct test of One-way Anova suggests that only Rainforest Alliance respondents are significantly younger than uncertified farmers of Tanggamus region. The multiple comparisons of One-way Anova also indicate that the organic farmers overall have considerable higher yields per hectare compared to the other groups. However, there is no clear evidence supporting that global certifications have increased the productivities of the certified farmers. For example, in West Lampung, Utz certified respondents averagely produce lower outputs per hectare than the uncertified respondents. Similarly, in Tanggamus Regency, 4C farmers have lower average productivity than the uncertified respondents in the neighborhood areas. Therefore, we assume that differences in smallholder preferences, if any, are mainly influenced by the certification types and factors (e.g. attitude) other than the respondents' characteristics. The overall education level of the respondents was low with an average of 8.46 years of formal education (see Appendix 3). In detail, more than $70 \%$ of the respondents did not complete 10 years of education, and $26 \%$ accomplished 12 years of formal schooling. The average productivity is 848.29 kilograms coffee per hectare but the number of coffee plants per hectare is unknown. The smallholders generally intersperse the coffee plants with other crops in the same parcel. Although they have been cultivating coffee for an average of 15 years, they are relatively new participants in the certification programs, with on average only 2.3 years of participation. 


\subsection{Farmer preferences and the ideal certification scheme}

The results of the conjoint analysis are twofold. First, it indicates the strength of the preferences for each attribute, or in other words: it reveals which attributes are considered most important in coffee certification schemes (see the percentages for the relative importance in Table 10 below). Second, the analysis offers utility (part-worth) scores and standard errors for each attribute level. These part-worth scores provide a quantitative degree of preferences for each attribute level; the larger these values, the greater the preference for the specific attribute level (IBM Corp., 2010). These two results combined, indicate which attributes are considered important and how the most preferred interpretation of these attributes look according to the smallholder farmers. Table 10 indicates both results for the overall farmer's preferences, and the preferences of farmers certified under 4C, Rainforest, Utz certified, and Inofice as well as the uncertified producers.

\section{Important certification attributes}

Table 10 shows that the most important attribute in the overall farmer preferences is the "Price Premium" with a relative importance of 21.9 per cent. Also highly preferred is the attribute of "Environmental focus" (14.1\%) and "Price differential between certified and uncertified coffee" (13.1\%). The latter is particularly valued by Inofice and uncertified farmers, whereas the global certified farmers attach more value to "the Important goal" (fairness or sustainability) of the certification scheme. This means that price premium, environmental focus and price differentiation between certified and uncertified coffee beans are important certification attributes for most farmers and that a scheme's focus is particularly important for globally certified farmers. The attributes of "Certification Target" (12\%), "Important goal" (11.6\%) and "Price differential based on the coffee bean sizes" (10.3\%) all have an overall relative importance between 10\% and $13 \%$ and can be interpreted as relatively important attributes in coffee certification. A comment we have to make at this point is that "Important goal" is relatively unimportant for the Inofice farmers, while being important for the other farmer groups. At the bottom of the list we find the attributes of "Marketing schemes" (9.9\%) and "Credit option" (7\%), which can therefore be considered less important in farmer's preferences for coffee certification. 
Farmer preferences for coffee certification: a conjoint analysis of the Indonesian smallholders

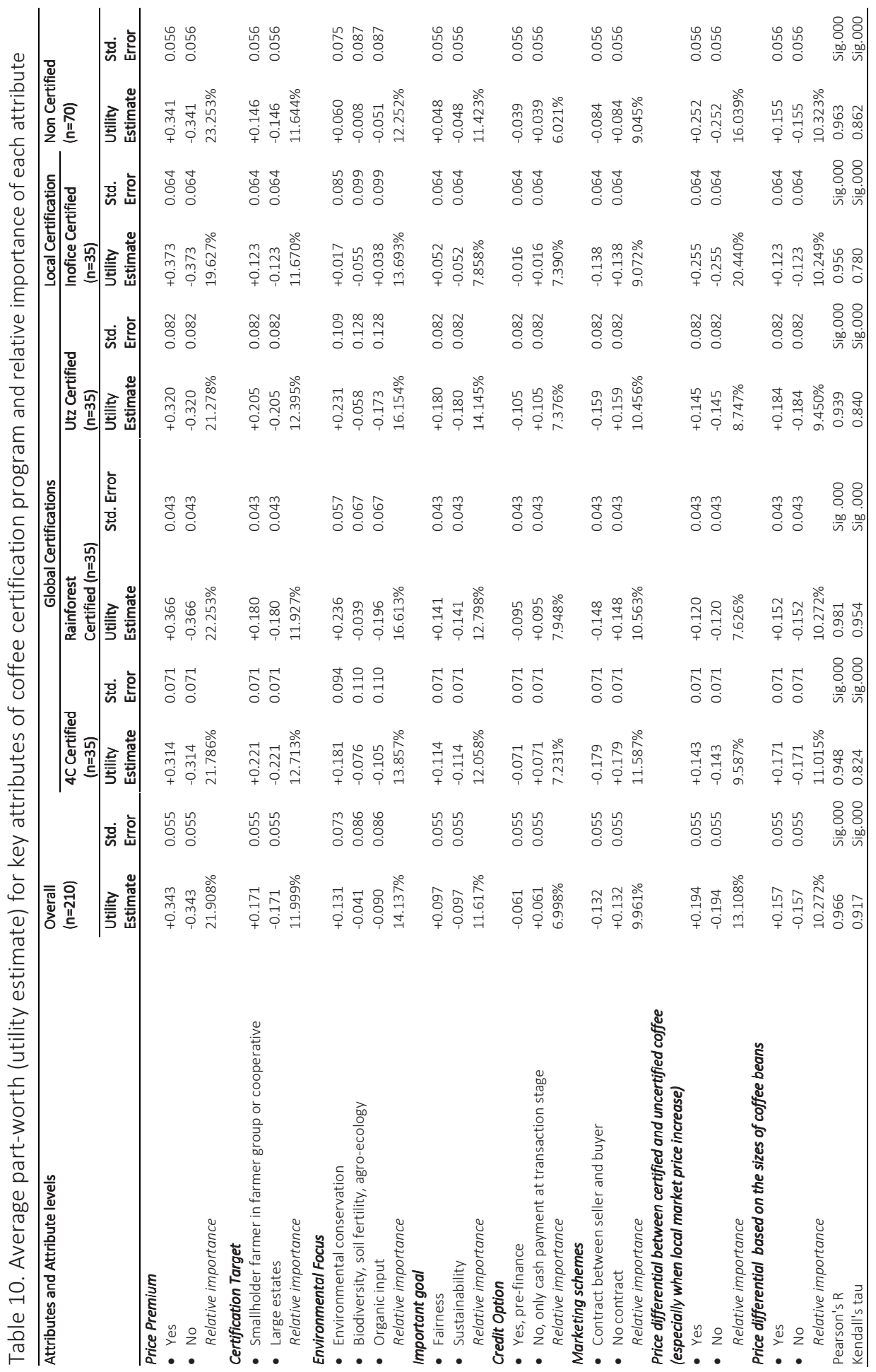


Most preferred certification scheme based on preferences for attribute levels

In general, the different farmer groups are rather comparable in terms of their preferences. The presence of a price premium is the most preferred attribute level with a utility score of +0.343 . Next, smallholders prefer environmental conservation, a price differential against uncertified coffee, farmer groups or cooperatives as target, emphasis on fairness, price differentials based on coffee bean sizes, no contract and no pre-finance (see Table 11 below). The preferences for the attribute levels are very comparable across the respondent groups, except for the environmental-focus attribute. While all farmers prefer the attribute level of environmental conservation, the smallholders certified under Inofice prefer organic input. Further, where the global certified farmers prefer fairness over a price differential based on certified and uncertified coffee, this is opposite for uncertified and Inofice farmers.

Table 11. Attribute level summary of the most preferred certification scheme

\begin{tabular}{|c|c|c|c|c|c|c|c|}
\hline Rank 1 & Rank 2 & Rank 3 & Rank 4 & Rank 5 & Rank 6 & Rank 7 & Rank 8 \\
\hline $\begin{array}{l}\text { Price } \\
\text { Premium }\end{array}$ & $\begin{array}{l}\text { Environmental } \\
\text { Focus }\end{array}$ & $\begin{array}{l}\text { Differential Price } \\
\text { with Noncertified } \\
\text { Farmers }\end{array}$ & $\begin{array}{l}\text { Certification } \\
\text { Target group }\end{array}$ & $\begin{array}{l}\text { Important } \\
\text { goal }\end{array}$ & $\begin{array}{l}\text { Differential } \\
\text { Price } \\
\text { Based on } \\
\text { Size }\end{array}$ & $\begin{array}{l}\text { Marketing } \\
\text { Schemes }\end{array}$ & $\begin{array}{l}\text { Credit } \\
\text { Option }\end{array}$ \\
\hline Yes & Conservation & Yes & $\begin{array}{l}\text { Smallholder } \\
\text { farmers in group } \\
\text { or cooperative }\end{array}$ & Fairness & Yes & $\begin{array}{l}\text { No } \\
\text { contract }\end{array}$ & $\begin{array}{l}\text { No } \\
\text { credit }\end{array}$ \\
\hline
\end{tabular}

\subsection{Assumptions underlying farmer's preferences}

Following the statistical results of the conjoint analysis, we conducted interviews to further explain the preferences. Related to the importance of the presence of a price premium we found that the poor farmers have a high expectation of the tangible economic benefits of the certification programs through a price premium. They perceive the price premium as a reward for following, or complying to, the activities and practices as required by the scheme. The interviews reveal that it was not only the price premium as such that was highly preferred, but also a more direct relation between the farmers and certificate holders, to ultimately gain a stronger bargaining power and guaranteeing a (higher) price premium for the certified coffee beans. Currently, the global certified respondents hold no certificates themselves. Roasting companies and exporting firms (Nestle, NedCoffee, and Indo Cafco) hold the certificates because they pay the certification costs. The farmers have an indirect relationship with these certificate holders as they collectively or individually deliver their harvests to KUBEs (Kelompok Usaha Bersama). KUBEs are joint business groups consisting of different producer groups that partner with a specific certificate holder and transport the coffee beans to the roasting companies or exporters after cleaning and drying the coffee beans. This procedure results in lower prices for the farmers as around 30\% of the premium prices goes to the KUBEs. Every transaction with exporters or roasters has to 
be conducted through KUBEs, although they also have relatively little bargaining power against the big buyers. Within the Inofice scheme, certificates are held by joint farmer groups called "Gabungan Kelompok Tani Hulu Hilir" often shortened as Gapoktan Hulu Hilir to whom the Inofice farmers directly sell their coffee beans, without the intervention of a KUBE. The uncertified smallholders commonly sell their coffee beans to local traders and local roasters with lesser requirements.

Farmers highly value the environmental focus of a certification scheme, in particular the focus on conservation. This can partly be explained by their understanding of conservation, namely beyond the coverage of forests, soil and biodiversity protection, and partly by their feeling of being connected to nature. Regarding the former, farmers value the preservation of historical heritage such as the Inscription of Batu Bedil and the Megalithic Site of Batu Gajah, and consider this to be part of the attribute of environmental conservation. Regarding the latter, the interviews reveal that farmers feel strongly connected to nature. They realize that for their coffee farming practices, and therefore also their income, they depend on the state of the environment. Particularly the older farmers compare the current environmental state with the state of years ago and express their concerns about decreasing bird populations and the poor water quality. The farmers believe that planting coffee in protected forests must either be banned or controlled, for example, by the Decree of the Minister of Forestry (No. 31/Kpts-II/2001). This decree provides opportunities for farmers to manage and to use state-forest lands, with the proviso that they must conserve the area. However, our interviews also reveal that, although the environmental focus is deemed important, the farmers would not choose a different certification scheme only because the environmental criteria are more rigorous.

Inofice certified and uncertified respondents indicate a high preference for price differentials between certified and uncertified coffee. Their underlying reasons are nevertheless different. On the one hand, the uncertified smallholders value their freedom to sell coffee to any buyer offering a high price or quick cash. Besides, if they manage to produce good quality coffee they can also sell to the KUBEs and cashing a higher price. According to them, coffee quality should be more important than the question whether the coffee is certified or not. On the other hand, the Inofice organic producers feel that they are participating in a certification program which uses strict environmental criteria. The certification program should therefore give a significant price differential for their "exclusive" coffee beans. The surveys reveal that the Inofice farmers obtain 3,000 rupiah (around €0.19) per kilogram more than the prevailing local market price for uncertified coffee. This desire for gaining a financial reward for more 
exclusive coffee could also be recognized among the global certified farmers (although they only receive a financial reward of 200-300 rupiah per kilogram of coffee).

Related to the certification target group, the respondents prefer the attribute level of smallholder farmers in a farmer group or cooperative rather than large estates. Our interviews reveal that farmers see the roles of their farmer groups as positive as they are believed to play vital roles in improving bargaining positions, solving problems, and managing and educating their members. The groups also organize the coffee growers to work together to build terraces, terrace drains, and ridges in each member's plantation. In addition, individual members are able to contribute cash to the groups' financial deposits, which can be used to jointly (and therefore more cheaply) buy fertilizers, tools, and seeds. These activities have produced strong social relations between the individual farmers and their groups. These relations are valued as being important by the farmers. According to the smallholders, they rarely encounter such emotional connections in relation to the large estate plantations, which usually employ many labor workers. The possibility to develop and maintain strong personal relationships explains the farmers' preference for farmers groups over large estates. A desire to act independently was not expressed during the pre-tests or the interviews. Most coffee farmers are smallholders owning limited land and capital. Joining a producer group is a need for almost every farmer rather than an obligation. Independent coffee smallholders are therefore very rare, except for those farmers whose livelihoods do not mainly depend on coffee.

Next to personal relationships, fairness is an important issue for most respondents; especially for the global certified farmers. This can again be related to their indirect relationship with the certificate holders (roasters and exporters). Farmers lack understanding on how prices are formulated by the certificate holders and - more importantly - have the feeling that they may not receive the prices they have the right to. The lack of negotiation opportunities contributed to lower trust and a feeling of unfairness. Furthermore, the smallholders perceive a lack of transparency about the advantages and content of the certification programs and the initiators behind these programs, which generates doubts about the fairness of these programs as well. Lastly, as being one of the most important actors within the certification scheme the farmers consider it unfair that things are simply decided upon for them.

The preference to differentiate prices based on the coffee bean sizes results from the practice that coffee roasters almost always separate the coffee beans in accordance to their size, to produce high-quality coffee products. If the beans are mixed, the smaller beans are scorched before the larger beans, which influence the coffee quality. Standar 
Farmer preferences for coffee certification: a conjoint analysis of the Indonesian smallholders

Nasional Indonesia (SNI) or The National Standard of Indonesia, the authority being in charge of regulating coffee quality, requires coffee beans to be graded and priced according to their size (BSN, 2014). Most farmers hope that grading requirements based on the bean sizes can also be applied under (global) certification schemes. The poor farmers call the grading exercise "ekah", which literally means "differentiating to increase income".

The preference for not having any formal contract with buyers is rooted in a desire to be able to adapt to opportunities to sell coffee for higher prices elsewhere or to maintain social relationships. For this attribute level again, we see that emotional attitude and social relations are important explanatory aspects behind the farmer's preferences. For example, while the coffee producers usually sell their coffee beans via their KUBEs to the exporting firms under a particular certification, they also continue to sell their coffee to local traders to maintain social relationships with these traders. In the neighborhoods, the smallholders and the local traders usually have a close relationship, comparable to family-ties or friendship. Finally, farmers indicate that they are not familiar with formal agreements and compliance, which keeps them rather reserved to opt for such a contract.

Unfamiliarity and a lack of understanding also play an important role in farmer's cautiousness about credit, especially credit or pre-finance offered through formal procedures. They perceive that such credits require collateral and formal requirements that are difficult to follow. The poor farmers usually rely on informal sources of financial aid, such as friends and extended families. Given uncertainty regarding the timing, and quantity of coffee bean harvests, farmers refer to pre-finance as a "debt risk" that could result in an unintended contract with the creditor (see previous point).

\subsection{Conclusion}

Most global coffee certification schemes are developed by Northern-based businesses and NGOs and regulate production in the South. Production requirements can often be traced back to the demands of global buyers that do not necessarily coincide with the demands and preferences of smallholder producers in the South. Understanding farmer preferences makes it however easier to take these preferences into account when (re)developing a certification scheme. This is believed to contribute to standards that are more acceptable to farmers and encompass better applicable strategies for improving farmers' productivity and income. Insight into motivations behind preferences contributes to knowledge about the current context and conditions smallholders have to cope with. This also implies that changes in context or structure 
may have implications for farmer's preferences. Therefore, the results of this study should not be treated as steady and unchangeable.

This study examined the preferences for coffee certification from a Southern producer's perspective by using the technique of conjoint analysis. The analysis reveals that our sample of Indonesian coffee farmers prefer a certification scheme that offers a price premium, focuses on environmental conservation, offers price differentials between certified and uncertified coffee, targets farmers in a group or cooperative, values fairness, offers a price differential based on the size of the coffee beans, and offers no formal contracts or credit options.

We learn that certification, which is meant to be a tool to promote sustainability and preferred by consumers in the North because of environmental and social conditions of production, becomes, when applied in the field and accepted by the farmers, an economic tool. This does not mean that the Indonesian coffee farmers do not value the environmental and social aspects of their production, but their preferences regarding the certification schemes are primarily economically driven. This observation is sustained by the fact that we hardly found differences in the preferences of globally certified farmers, locally certified farmers and uncertified farmers; they all prefer certification schemes that can promise tangible economic benefits. This implies that certification is only weakly institutionalized among farmers. Farmers display opportunistic behavior and may abandon one certification scheme to participate in another when the second one, or an alternative system, promises higher financial incentives. The current system that can be characterized by an overproduction of certified coffee (supplies outweigh demands), leads to a situation wherein certified coffee is sold in the conventional market. Premium prices can thus no longer be guaranteed, which may lead farmers to decide to leave the certification scheme. This trend may be further exacerbated by new emerging markets (including the domestic Indonesian market) that do not require coffee to be certified. From a liberal-market point of view this may not be problematic, but it shows again that the current certification systems are weakly institutionalized in farmer's practices.

We also found that farmer's knowledge about the certification schemes is low. Knowledge does generally only cover the recommended activities (like harvesting ripe cherries) and unacceptable practices that should be prevented within their own scheme (like the use of banned pesticides). This may explain why the description of attributes (also in the pre-tests) kept a rather general character. Farmers are simply not aware of differences between the certification schemes and can therefore not think of attribute levels that go beyond their own scheme. 
This research offers new and interesting insights for science, practice and certification issuers, but only covered Robusta coffee farmers in two areas in Indonesia. Further research including Arabica farmers in different parts of the Archipelago will be necessary to further test the findings. In that research the conjoint analysis, although a robust method could be improved. Conjoint analysis limits the number of attributes and attributes levels that can be included in an analysis. Social attributes were purposely excluded from our attribute list as they were considered irrelevant by the farmers in the pre-tests. However, it may be interesting to further investigate farmer's ideas and preferences for price premium alternatives. Repeating this study with the incorporation of different certification attributes related to tangible economic aspects, but also aspects related to farmer's preferences regarding organizational capacity or skills (e.g. what is their need regarding skill development) may offer interesting, additional insights. 



\section{Chapter}

\section{Competing explanations for Indonesian smallholder participations in sustainability coffee certifications}

This chapter is based on:

Ibnu, M., Offermans, A., Glasbergen, P., \& Ismono, H. (2016). Competing Explanations for Indonesian Smallholder Participations in Sustainability Coffee Certifications. Journal of economics and sustainable development, 7(24), 123136. 


\subsection{Introduction}

Since the last two decades, we can observe a steady growing number of private sustainability standards and certification schemes to address sustainability issues in the coffee sector (Glasbergen and Schouten, 2015). These schemes are commonly initiated by Northern-based businesses and NGOs and govern the production of coffee in the South (Bitzer \& Glasbergen, 2015; Bitzer et al., 2013; Arifin 2010). These certification schemes do not only regulate production and processing methods related to better environmental and social conditions, but also aim to open opportunities for better market access, improve competitiveness of Southern farmers, improve rural livelihoods, and contribute to poverty alleviation (Hoffmann \& Grothaus, 2015).

Various certification schemes with many sustainability claims exist and compete with each other, in the coffee sector (Reinecke et al., 2012). Although participation is voluntary, the standards and certification schemes gradually put more pressure on the coffee markets and induce a change in the way production at the local level is managed. The standards and certifications have become de facto market requirements for suppliers of developing countries to be able to enter (parts of) international markets (Bitzer et al., 2013). The specific characteristics and conditions of the countries where the certification schemes are implemented can influence the adoption of the certifications (Manning et al., 2012). In the South, Indonesia is a country with a significant coffee producing sector characterized by a large number of small farmers (i.e. around 1.96 million coffee-growing households) who share 1.27 million hectares of coffee land across the country (BPS-Statistics Indonesia, 2013; Wahyudi \& Jati, 2012). Some of the leading coffee certification schemes are active in Indonesia, such as Utz, 4C, Rainforest Alliance (RA), and Fairtrade (FT). However, as only $7 \%$ of the exported Indonesian coffee is certified (SCP, 2014), the certification adoption rate can be considered very low (around a few per cent of the Indonesian smallholders).

Although farmers may benefit from certification, they are often hesitant to join the programs, as this requires them to change their behavior and agricultural practices. Furthermore, participation in certification changes the relationships with other actors, such as local traders or middlemen (Wahyudi \& Jati, 2012). These changes are often regarded as a sensitive issue in the Indonesian context where social relations are an important element within the social structure and need to be preserved. Through changes in the social structure and daily practices, the implementation of the certification schemes can therefore affect the whole network of actors in the Indonesian coffee value chain. 
In this context, and given the discussion about (potential) benefits in the literature (Becchetti \& Costantino, 2008; Raynolds et al., 2007; Rueda \& Lambin, 2013), it is important to develop knowledge about farmers' decisions to participate in the certification schemes. However, up to now researchers provide different explanations for participation. We observe that these explanations can be clustered into four dominant ones: socio-demographic, economic, attitudinal, and institutional explanations.

This paper aims to contribute to the discussions about motivations to participate by bringing some order in the current explanations. We particularly aim to answer the question of the relative importance of the various explanations. Therefore, we reformulated the explanations into hypotheses and connected variables to each of them, which were further operationalized in relevant items. These items were used to develop structured questionnaires, which were filled-out in personal interviews with farmers in Indonesia. In the next section, we present the hypotheses based on a literature review. In section three and four we describe our methods (operationalization of the hypotheses, Heckman selection model with a two-step procedure and an overview of our respondents) and present our results. Section five contains conclusions and a reflection.

\subsection{Explanations for smallholder participation in sustainability coffee certification: a review of the literature}

The literature on farmer participation in sustainability certification schemes is rather rich of explanations. Based on a review of this literature, we can distinguish at least four categories of explanations.

The first category refers to economic motivations. Loconto \& Dankers (2014), for example, observed in their review of the impact of voluntary standards on market participation in developing countries that prospects for higher profitability will influence whether or not smallholders participate in certified value chains. Ibnu et al. (2015) found that poor coffee farmers in Indonesia have a high expectation of the tangible economic benefits of the certification programs through a price premium. Rueda \& Lambin (2013) showed that the promise of a premium was the reason why $60 \%$ of certified Colombian coffee farmers in their research decided to join the program; while $96 \%$ referred to economic benefits as increased productivity and better quality coffee beans (Rueda \& Lambin, 2013). 
Based on the results of these studies we formulate the following hypothesis:

Farmers who perceive that joining certification is ideally needed for obtaining a price premium, increased productivity and quality are likely to join certification programs.

The second category refers to social-demographic characteristics of the farmers. First, there is some evidence that farm size is positively correlated with participation in certifications (Loconto \& Dankers, 2014). Second, research on coffee farmers in Africa showed that certification seems to be particularly attractive for farmers for whom coffee is their main source of income, and who depend less on other crops or off-farm activities to gain their income (Hoebink et al., 2014). Third, research among different categories of farmers in different countries (e.g., Sri Lanka, Rwanda) indicates that farmers who are younger and better educated are generally regarded more receptive to a wider range of practices and the adoption of new technologies (Illukpitiya \& Gopalakrishnan, 2004; Mujawamariya et al., 2013).

Based on the results of these studies we formulate a second hypothesis:

Farmers who are younger and better educated, own larger farms, and for whom coffee is their main source of income, are likely to join a certification program.

The third category refers to attitudinal explanations. First, we found evidence suggesting that risk-taking farmers in developing countries are more likely to adopt new conservation practices compared to farmers who prefer to play it safe (De Graaff et al., 2008; Hoebink et al., 2014). Second, we found that a pro-active attitude towards seeking information can be positively correlated to participation in certification. Kessler (2006), for example, found that Bolivian farmers' pro-active attitude in seeking information corresponds to their willingness to change, to improve, and to participate in conservation adoption and investment programs. The third type of attitude that is acknowledged to play a role in certification adoption refers to the attitude towards the environment. According to Nuva et al. (2013) and Rueda \& Lambin (2013), certified Colombian and Indonesian coffee farmers have a relatively positive attitude towards the environment. Besides, they were found to express concerns regarding the substantial use of agrochemical substances and the limited use of organic input, and shade trees for enhancing biodiversity in coffee plantations. As these farmers may have had a positive environmental attitude prior to joining certification already, and as this may be an explanatory factor for participation, we decided to include this variable in the hypothesis. Based on the findings of these attitudinal studies we formulate the third hypothesis:

Farmers with a risk-taking attitude, who pro-actively seek information, and who have a positive attitude towards the environment are likely to participate in coffee certifications. 
The fourth and last category refers to institutional explanations. Empirical studies have positively linked the existence of producer associations (or farmer groups) to the abilities of Brazilian and Indonesian coffee farmers to participate in certification schemes (Nuva et al., 2013; Pinto et al., 2014). These authors specifically refer to farmer groups' roles in organizing collective work and group farming systems, in their contribution in overcoming individual limitations such as capital shortcomings, or a lack of knowledge or skills, to explain the positive link between membership of a farmer group and participation in certification (Nuva et al., 2013; Pinto et al., 2014). Next to farmer groups, cooperatives are also found to play important roles in connecting farmers to coffee certification schemes in Brazil and Indonesia (Nuva et al., 2013; Pinto et al., 2014). More specifically, the cooperatives' technical support, coordination in buying up coffee beans, and their role in the provision of information are believed to positively contribute to farmer's participation in certification schemes (Nuva et al., 2013). Third, and following Nuva et al. (2013), the distance of farmer's households to cooperatives is believed to correlate negatively to farmer's participation in certification.

Based on the previous studies, and following the fact that the Indonesian KUBEs ${ }^{18}$ (Kelompok Usaha Bersama) have the same institutional set-up and roles as cooperatives in other developing countries (see Ibnu et al., 2015 for more information), we formulate a fourth hypothesis:

Farmers who are institutionally embedded in well-functioning farmer groups and cooperatives or KUBES, and who live relatively close to cooperatives or KUBES are likely to join certification programs.

\subsection{Methods}

\section{The operationalization of the hypotheses}

We designed the questions for both certified and uncertified farmers based on the operationalization of the variables in the hypotheses (see Table 12 below). All the questions can be found in Appendix 4. The economic benefits were measured through the prospects of price premium, productivity, and quality. We asked the certified farmers whether the three prospects drove their decisions to participate in the standards. In contrast, we asked the uncertified producers whether they do not join the certifications because they lack confidence in the realization of the prospects.

\footnotetext{
${ }^{18}$ KUBEs are joint business groups consisting of different producer groups that partner with a certificate holder and transport the coffee beans to the roasting companies or exporters after cleaning and drying the coffee beans.
} 
Table 12. Operationalization of the variables

\begin{tabular}{|c|c|c|c|}
\hline Explanation & Variable & Operationalization & Unit of measurement \\
\hline Economic & $\begin{array}{l}\text { Price premium } \\
\text { Increased } \\
\text { productivity } \\
\text { Improved quality }\end{array}$ & $\begin{array}{l}\text { Prospect of price premium } \\
\text { Prospect of increased productivity } \\
\text { Prospect of increased quality }\end{array}$ & A five-point-Likert scale \\
\hline \multirow[t]{5}{*}{$\begin{array}{l}\text { Socio- } \\
\text { demographic }\end{array}$} & $\begin{array}{l}\text { Dependency on } \\
\text { other sources of } \\
\text { incomes }\end{array}$ & $\begin{array}{l}\text { - Income from other crops and off- } \\
\text { farm activities }\end{array}$ & Rupiah \\
\hline & $\begin{array}{l}\text { Coffee as main } \\
\text { source of income }\end{array}$ & $\begin{array}{l}\text { Income coffee minus incomes from } \\
\text { other crops and off-farm activities. }\end{array}$ & $\begin{array}{l}\text { Value } 1 \text { if the income is } \\
\text { positive, and value } 0 \text { if } \\
\text { negative. }\end{array}$ \\
\hline & Farm size & Farm size & Hectare \\
\hline & Age & Age & Years \\
\hline & Education & Education & Years \\
\hline \multirow[t]{3}{*}{ Attitudinal } & $\begin{array}{l}\text { Environmental } \\
\text { concerns }\end{array}$ & $\begin{array}{l}\text { - Environmental farm management } \\
\text { - } \text { Reducing chemical inputs } \\
\text { - Increasing organic input } \\
\text { - Increasing shade trees }\end{array}$ & A five-point-Likert scale \\
\hline & Taking risk & $\begin{array}{l}\text { - Taking opportunities } \\
\text { - Avoidance/ playing it safe }\end{array}$ & A five-point-Likert scale \\
\hline & Seeking information & $\begin{array}{l}\text { - Pro-actively seeking information } \\
\text { - Increasing knowledge by discussion }\end{array}$ & A five-point-Likert scale \\
\hline \multirow[t]{3}{*}{ Institutional } & $\begin{array}{l}\text { Embeddedness in } \\
\text { well-functioning } \\
\text { farmer groups }\end{array}$ & $\begin{array}{l}\text { - Regular meetings } \\
\text { - Collective actions } \\
\text { - Arisan/ community gatherings } \\
\text { - Gotong royong/ communal work } \\
\text { - Collecting, processing and } \\
\text { bargaining }\end{array}$ & $\begin{array}{l}\text { A three-point-Likert } \\
\text { scale }\end{array}$ \\
\hline & $\begin{array}{l}\text { Embeddedness in } \\
\text { well-functioning } \\
\text { KUBES }\end{array}$ & $\begin{array}{l}\text { - Information provision } \\
\text { - } \text { Facilitation/ support in buying and } \\
\text { contacting } \\
\text { - Increase market access } \\
\text { - Support in managing finances }\end{array}$ & \\
\hline & $\begin{array}{l}\text { Presence of near-by } \\
\text { Cooperative or } \\
\text { KUBE }\end{array}$ & $\begin{array}{l}\text { Distance between farmer's household } \\
\text { and KUBE }\end{array}$ & Kilometers \\
\hline
\end{tabular}

Coffee as main source of income is, following the earlier presented hypothesis on sociodemographic explanations, also considered as a variable in this study. We operationalized this variable by measuring the magnitude of coffee income relative to non-coffee income (i.e., income that farmers obtain from selling other crops like banana, avocado, pepper and orange and doing off-farm activities). We calculated the relative magnitude by subtracting the non-coffee income (in Rupiah) from the coffee income (in Rupiah), and gave value 1 if the income from coffee is larger than the noncoffee income, and value 0 if the opposite is true. An important conceptual difficulty in measuring this variable relates to the fact that the current coffee income is probably influenced by the impacts of certification, whereas we basically want to measure the 
coffee- and non-coffee income before joining certification. We further measured the variables of age and education in years, and farm sizes in hectares.

The attitudinal explanation was measured by evaluating the farmers' perceptions of ideal conditions in the case of environmental perception, and the reality of their practices in the case of seeking information and taking risk. This way of measuring enabled us to evaluate the respondents' attitude if they are given a similar situation or choice. The current literature shows that certified farmers, prior to their decision to participate in coffee certification, tend to be more concerned about the environment than conventional farmers (Rueda \& Lambin, 2013). As we acknowledge that being concerned about the environment does not necessarily go together with the execution of conservation practices (for example because of budget constraints) we measured perceptions of the environment in an ideal situation. More specifically, the variable on environmental concerns is operationalized through asking how the ideal management of the farm would look like, and whether the use of chemical inputs, organic inputs and shade trees should ideally be lowered (chemical inputs) or increased (organic input and shade trees) even if this lowers profits. Literature on the attitude towards risk and seeking information explicitly refer to actual behavior. The attitude towards risk was measured through asking whether farmers easily take opportunities and whether they prefer to play it safe. We also asked the certified farmers whether they joined certification because they had the opportunity to do so, and we asked the uncertified farmers whether they would consider certification adoption whenever there is an opportunity. Seeking information was measured in two questions: one focusing on the general idea of seeking information, and one question on gaining information through pro-actively discussing with others.

The institutional explanation was operationalized by asking the farmers whether they are part of farmers groups, cooperatives or KUBEs and whether they believe that these groups function well in terms of organizing periodic informal meetings to discuss farming-related issues; sharing knowledge and information; organizing collective actions to buy farm inputs (e.g. fertilizers, seeds, and tools); sharing costs (e.g. to buy hulling coffee machine); organizing community gatherings (arisan); organizing gotong royong (i.e. a form of communal work or mutual aid) to build terraces, drain terraces, and ridges; supporting in post-harvest activities to collect, process, and control the quality of coffee harvests; and representing the members in bargaining with cooperatives or KUBEs.

For the Cooperative or KUBE we added functions related to the provision of information about coffee certification programs, markets and new technologies. Also their roles in contacting extension agents or experts from universities to give advice, trainings, 
seminars or workshops were included in the questionnaire. Cooperatives and KUBEs have further roles to improve the market access to exporting firms, provide a better market option than selling to conventional markets, manage the financial savings of members, give credits or loans to its members, and pay farmers on time. Finally, we measured the distance between a farmer's household and a KUBE.

\section{Heckman selection model (two-step procedure)}

The strength of an explanation is determined by the relative importance of the variables in explaining the decision to participate or not. To measure the variables' relative importance, we used the Heckman selection model. We used this model because it offers a framework for correcting non-randomly selected samples and allows correcting for selection bias (Bushway, Johnson, \& Slocum, 2007; Marchenko \& Genton, 2012). Selection bias potentially results from self-selection of the research objects and/or the influence of endogenous variables. The former occurs when farmers join certification as a matter of self-selection, for example if certification is only or mainly considered by farmers who are qualified to participate (and economically better off) and researchers have little information about this bias. The latter becomes a source of bias if endogenous variables (e.g. the prospects of price premium and increased productivity) are treated only as independent variables (in fact they are also influenced by other variables in the research framework) (Berk, 1983). These selection biases may influence the validity of the causation model (regression), and Heckman's model is designed to address these problems. The Heckman selection model uses a two-step procedure to model (and correct) selection bias by proposing an equation (regression) for each step (StataCorp. 2013). The logic of Heckman's sample selection correction is that it first models the selection process (step 1) and then corrects for bias by incorporating the conditional probabilities as an explanatory variable to the derived equation (step 2).

In this paper, the first procedure (step 1) involves a regression model to evaluate farmers' decision to participate in certification through examining the influence of socio-demographic (i.e., non-coffee Income, coffee income minus non-coffee income, farm size, age, and education), attitudinal (environmental attitude, taking opportunity, avoiding 'playing it safe', seeking information, discussion to increase knowledge ) and institutional variables (embeddedness in well-functioning farmer group, embeddedness in well-functioning Cooperative/KUBE, and distance to cooperative/KUBE). The second procedure (step 2) involves a regression model to evaluate farmers' decision to participate by examining the influences of all independent variables from the hypotheses. Step 2 includes both exogenous (e.g., farm size, age, and education) and endogenous (e.g., the prospect of price premium and the prospect of increased productivity and quality) variables. Each step calculates a residue or a set of unknowns 
(the unobservables) for each observation (i.e., the value, at a particular period, of a particular variable). If the unobservables in the step 1 model are correlated with the unobservables in the step 2 model, we have biased estimates (without correction). In other words, unobservables in the step 1 model are also affecting the step 2 model indicating selection bias. The Heckman selection model produces consistent estimates and solves the problem of selection bias through examining the unobservables for each observation (StataCorp. 2013) and evaluating their influence in the final regression model.

To test for selection bias, we compute rho that is correlation between the unobservables in step 1 and step 2. When rho is positive, this indicates that unobservables are positively correlated with one another and therefore selection bias cannot be ignored. In this case, if the Heckman selection model is not used, the results of the regression model may be inconsistent (Bushway, Johnson, \& Slocum, 2007; Marchenko \& Genton, 2012). To further see whether selection bias is corrected with Heckman's method, we calculate Mills lambda in the final regression that reflects potential influences of unobserved variables on the dependent variable (StataCorp. 2013).

To evaluate the economic and the attitudinal explanations, we used a five-point-Likertscale, ranging from 1 (strongly disagree) to 5 (strongly agree). For the institutional explanation, we used a three-point scale ranging from 0 (institutions do not fulfil the mentioned roles), through 1 (institutions sometimes fulfil the mentioned roles) to 2 (institutions fully fulfil the mentioned roles). For the socio-demographic explanations, we measured all items, except for the earlier explained "coffee as main source of income" on a scale level. We used Stata (statistical program) to run Heckman's procedure.

The relative strength of each explanation is determined by the coefficient of the variable in the regression model, and considered significant if the P-value is equal to, or lower than, 0.05. The sign of the coefficient (positive or negative) shows the direction of the influence the variable has in relation to farmer participation. We summed the individual coefficients of the significant variables in each domain (i.e. economic, sociodemographic, attitudinal, and institutional) to obtain an overall and comparable coefficient value per explanation. The certified farmers participated in different certification schemes. We used the One Way Anova test to analyze potential differences in answers among schemes, adopting again a P-value of 0.05 or lower. 


\section{Respondent selection and characteristics}

We surveyed coffee farmers in Aceh (i.e., Bandar District) and Lampung (i.e., Tanggamus and West Lampung Districts) provinces. In Indonesia, Aceh and Lampung are known as significant coffee producing regions where the farmers cultivate Arabica and Robusta coffee respectively. The Arabica farmers in the Bandar District mostly participate in the Fairtrade (FT) scheme, whereas the Robusta producers joined Rainforest Alliance (RA), Utz certified, and 4C certifications. The competition among the schemes in the regions was low as only one scheme was present in each village. The farmers were randomly selected in various sub-districts and villages. We interviewed 80 certified and uncertified farmers, resulting in 160 respondents in total. From each scheme, we interviewed 20 farmers (see Table 13 below). The uncertified farmers live in the neighboring villages of the certified producers and most of them have at least some knowledge about certification from their KUBEs or cooperatives.

Table 13. Sample sizes and respondent distributions

Distribution of respondents groups Distribution of respondents based on their participation in certification schemes

1. Certified farmers $=80$ respondents 1. Fairtrade $(F T)=20$ respondents

2. Uncertified farmers $=80 \quad$ 2. $4 \mathrm{C}=20$ respondents respondents 3. Utz $=20$ respondents

4. Rainforest Alliance $(\mathrm{RA})=20$ respondents

\subsection{Explanations for the Indonesian smallholders to participate in sustainable coffee certification}

\section{Heckman selection model (the first step)}

Table 14 presents the results of the first step (regression) involving the effects of sociodemographic characteristics, and attitudinal and institutional explanations on the decision to participate. The results indicate that coffee income minus non-coffee income, farm size, and education positively influence the decision to participate. These means that farmers with more coffee income than non-coffee income, owning larger farms, and having better education are likely to join a certification program. Embeddedness in well-functioning farmer group has a (significant) negative effect, implying that farmers with a relatively well-functioning farmer group are less likely to participate in coffee certification than farmers with less-functioning farmer group. In the second step, however, the Heckman's method reduces selection bias by changes the significances of these variables (see Table 15 below). In the final regression, coffee income minus non-coffee income and education are found to be not significant, but non-coffee income and avoiding 'playing it safe' come up as significant variables that influence farmers' participation. The Heckman's method also corrects the bias by 
changing the influence of embeddedness in well-functioning farmer group from negative to positive.

Table 14. Regression with Heckman selection model (the first step)

$\begin{array}{llll}\text { Coefficient } & \text { Std. } & \mathrm{z} & \mathrm{P}>|\mathrm{z}|\end{array}$ [95\% Conf. Interval]

Error

\begin{tabular}{|c|c|c|c|c|c|c|}
\hline \multicolumn{7}{|l|}{ Socio-demographic } \\
\hline $\begin{array}{l}\text { Coffee income minus } \\
\text { non-coffee income }\end{array}$ & 0.782 & 0.189 & 4.14 & $0.000 *$ & 0.412 & 1.151 \\
\hline Non-Coffee Income & -0.011 & 0.009 & -1.21 & 0.228 & -0.03 & 0.007 \\
\hline Farm Size & 0.221 & 0.132 & 1.68 & $0.093 *$ & -0.037 & 0.479 \\
\hline Age & -0.006 & 0.01 & -0.65 & 0.514 & -0.025 & 0.013 \\
\hline Education & 0.059 & 0.031 & 1.89 & $0.059 *$ & -0.002 & 0.12 \\
\hline \multicolumn{7}{|l|}{ Attitudinal } \\
\hline Environmental attitude & 0.022 & 0.074 & 0.29 & 0.770 & -0.123 & 0.166 \\
\hline Taking opportunity & 0.133 & 0.138 & 0.96 & 0.335 & -0.137 & 0.402 \\
\hline Avoiding 'playing it safe' & 0.033 & 0.056 & 0.58 & 0.559 & -0.077 & 0.142 \\
\hline Seeking information & 0.062 & 0.088 & 0.70 & 0.483 & -0.11 & 0.234 \\
\hline $\begin{array}{l}\text { Discussion to increase } \\
\text { knowledge }\end{array}$ & -0.229 & 0.155 & -1.48 & 0.139 & -0.532 & 0.074 \\
\hline \multicolumn{7}{|l|}{ Institutional } \\
\hline $\begin{array}{l}\text { Embeddedness in well- } \\
\text { functioning farmer } \\
\text { group }\end{array}$ & -0.33 & 0.036 & -9.20 & $0.000 *$ & -0.401 & -0.26 \\
\hline $\begin{array}{l}\text { Embeddedness in well- } \\
\text { functioning }\end{array}$ & -0.069 & 0.046 & -1.50 & 0.133 & -0.159 & 0.021 \\
\hline Cooperative/KUBE & & & & & & \\
\hline $\begin{array}{l}\text { Distance to } \\
\text { cooperative/KUBE }\end{array}$ & -0.137 & 0.102 & -1.35 & 0.176 & -0.336 & 0.062 \\
\hline Cons & 3.437 & 1.784 & 1.93 & 0.054 & -0.06 & 6.934 \\
\hline
\end{tabular}

*. Significant at the cut value 0.05

\section{Heckman selection model (the second step)}

Table 15 presents the results of the second step in the regression analysis, covering all variables in our hypotheses. The results further indicate that only a few variables from each explanation significantly influence the decision to participate in certification. These findings have several implications:

The first implication relates to the economic hypothesis (hypothesis 1 ). The findings reveal that while the prospect of quality does not seem to play a role in the decision to participate, the prospects of a price premium and increased productivity can be 
Chapter 3

considered crucial. The prospect of a price premium is even the most important explanation for farmer participation in Table 15 (with a coefficient value of 0.975).

Table 15. Regression with Heckman selection model (the second step)

\begin{tabular}{|c|c|c|c|c|c|c|c|}
\hline & $\begin{array}{c}\text { Coeffici } \\
\text { ent }\end{array}$ & $\begin{array}{l}\text { Std. } \\
\text { Error }\end{array}$ & $z$ & $P>|z|$ & \multicolumn{2}{|c|}{$\begin{array}{l}\text { [95\% Conf. } \\
\text { Interval] }\end{array}$} & $\begin{array}{l}\text { Explanatory } \\
\text { strength }\end{array}$ \\
\hline \multicolumn{8}{|l|}{ Socio-demographic } \\
\hline $\begin{array}{l}\text { Coffee income } \\
\text { minus non-coffee } \\
\text { income }\end{array}$ & 6.095 & . & . & . & . & . & \\
\hline $\begin{array}{l}\text { Non-Coffee } \\
\text { Income }\end{array}$ & -0.056 & 0.017 & -3.27 & $0.001 *$ & -0.089 & -0.022 & 7 \\
\hline Farm Size & 0.955 & 0.301 & 3.17 & $0.002 *$ & 0.364 & 1.546 & 2 \\
\hline Age & -0.017 & 0.024 & -0.68 & 0.494 & -0.065 & 0.031 & \\
\hline Education & 0.097 & 0.089 & 1.09 & 0.277 & -0.078 & 0.271 & \\
\hline \multicolumn{8}{|l|}{ Economic } \\
\hline $\begin{array}{l}\text { Prospect of Price } \\
\text { premium }\end{array}$ & 0.957 & 0.23 & 4.17 & $0.000 *$ & 0.507 & 1.407 & 1 \\
\hline $\begin{array}{l}\text { Prospect of } \\
\text { Productivity }\end{array}$ & 0.424 & 0.164 & 2.59 & $0.010 *$ & 0.103 & 0.745 & 4 \\
\hline Prospect of Quality & 0.056 & 0.181 & 0.31 & 0.759 & -0.299 & 0.410 & \\
\hline \multicolumn{8}{|l|}{ Attitudinal } \\
\hline $\begin{array}{l}\text { Environmental } \\
\text { attitude }\end{array}$ & 0.051 & 0.215 & 0.24 & 0.812 & -0.369 & 0.471 & \\
\hline $\begin{array}{l}\text { Taking } \\
\text { opportunity }\end{array}$ & -0.167 & 0.245 & -0.68 & 0.496 & -0.647 & 0.313 & \\
\hline $\begin{array}{l}\text { Avoiding 'playing } \\
\text { it safe' }\end{array}$ & 0.282 & 0.108 & 2.62 & $0.009 *$ & 0.071 & 0.493 & 5 \\
\hline $\begin{array}{l}\text { Seeking } \\
\text { information }\end{array}$ & -0.061 & 0.176 & -0.35 & 0.728 & -0.407 & 0.284 & \\
\hline $\begin{array}{l}\text { Discussion to } \\
\text { increase } \\
\text { knowledge }\end{array}$ & 0.426 & 0.312 & 1.36 & 0.173 & -0.186 & 1.037 & \\
\hline \multicolumn{8}{|l|}{ Institutional } \\
\hline $\begin{array}{l}\text { Embeddedness in } \\
\text { well-functioning } \\
\text { farmer group }\end{array}$ & 0.204 & 0.108 & 1.89 & $0.059 *$ & -0.008 & 0.416 & 6 \\
\hline $\begin{array}{l}\text { Embeddedness in } \\
\text { well-functioning } \\
\text { Cooperative/KUBE }\end{array}$ & 0.115 & 0.094 & 1.22 & 0.223 & -0.07 & 0.299 & \\
\hline $\begin{array}{l}\text { Distance to } \\
\text { cooperative/KUBE }\end{array}$ & -0.536 & 0.239 & -2.25 & $0.025^{*}$ & -1.004 & -0.068 & 3 \\
\hline Cons & -10.153 & 5.011 & -2.03 & 0.043 & -19.973 & -0.332 & \\
\hline Mills lambda & 0.495 & 0.242 & 2.05 & 0.041 & 0.021 & 0.969 & \\
\hline rho & 0.781 & & & & & & \\
\hline sigma & 0.634 & & & & & & \\
\hline
\end{tabular}

*. Significant at the cut value 0.05 
The Anova test (Table 16 below) indicates that all certified farmers had a high expectation about the price premium prior to certification (average mean score=3.98); the uncertified farmers, however, do not really believe in this price premium (mean score $=2.46$, $p$-value $=0.00$ ). In terms of the prospects for increased productivity, Utz certified and RA certified farmers do not significantly differ from the uncertified respondents. This implies that the prospect of increased productivity was particularly important for $4 \mathrm{C}$ and $\mathrm{FT}$ farmers in their decision to participate in certification.

Table 16. The Bonferroni test results of One Way Anova for multiple comparisons of certification schemes

\begin{tabular}{|c|c|c|c|c|c|c|c|}
\hline \multirow[b]{2}{*}{$\begin{array}{l}\text { Dependent } \\
\text { Variable }\end{array}$} & \multirow[b]{2}{*}{ (I) Schemes } & \multirow[b]{2}{*}{ (J) Schemes } & \multirow[b]{2}{*}{$\begin{array}{l}\text { Mean } \\
\text { Difference (I-J) }\end{array}$} & \multirow[b]{2}{*}{$\begin{array}{l}\text { Std. } \\
\text { Error }\end{array}$} & \multirow[b]{2}{*}{ Sig. } & \multirow{2}{*}{$\begin{array}{l}95 \% \\
\text { Interval } \\
\text { Lower } \\
\text { Bound }\end{array}$} & \multirow{2}{*}{$\begin{array}{l}\text { Confidence } \\
\text { Upper } \\
\text { Bound }\end{array}$} \\
\hline & & & & & & & \\
\hline \multirow[t]{4}{*}{ Non coffee income } & Uncertified & $4 C$ & $15.79588^{*}$ & 4.83153 & .013 & 2.0368 & 29.5550 \\
\hline & & UTZ & $17.17538^{*}$ & 4.83153 & .005 & 3.4163 & 30.9345 \\
\hline & & $\mathrm{FT}$ & 4.92288 & 4.83153 & 1.000 & -8.8362 & 18.6820 \\
\hline & & RA & $17.89288^{*}$ & 4.83153 & .003 & 4.1338 & 31.6520 \\
\hline \multirow[t]{4}{*}{ Farm size } & FT & $4 C$ & $1.37500^{*}$ & .25737 & .000 & .6421 & 2.1079 \\
\hline & & UTZ & $1.33750^{*}$ & .25737 & .000 & .6046 & 2.0704 \\
\hline & & $\mathrm{RA}$ & $1.08750^{*}$ & .25737 & .000 & .3546 & 1.8204 \\
\hline & & Uncertified & $1.15781^{*}$ & .20347 & .000 & .5784 & 1.7373 \\
\hline \multirow{4}{*}{$\begin{array}{l}\text { Prospect of price } \\
\text { premium }\end{array}$} & Uncertified & $4 C$ & $-1.53750^{*}$ & .25019 & .000 & -2.2500 & -.8250 \\
\hline & & UTZ & $-1.88750^{*}$ & .25019 & .000 & -2.6000 & -1.1750 \\
\hline & & $\mathrm{FT}$ & $-1.53750^{*}$ & .25019 & .000 & -2.2500 & -.8250 \\
\hline & & RA & $-1.13750^{*}$ & .25019 & .000 & -1.8500 & -.4250 \\
\hline \multirow{4}{*}{$\begin{array}{l}\text { Prospect of } \\
\text { productivity }\end{array}$} & Uncertified & $4 C$ & $-1.06250^{*}$ & .30535 & .007 & -1.9321 & -.1929 \\
\hline & & UTZ & -.86250 & .30535 & .054 & -1.7321 & .0071 \\
\hline & & $\mathrm{FT}$ & $-1.21250^{*}$ & .30535 & .001 & -2.0821 & -.3429 \\
\hline & & RA & -.66250 & .30535 & .316 & -1.5321 & .2071 \\
\hline \multirow{4}{*}{$\begin{array}{l}\text { Avoiding 'playing it } \\
\text { safe' }\end{array}$} & Uncertified & $4 C$ & $-1.58750^{*}$ & .44856 & .005 & -2.8649 & -.3101 \\
\hline & & UTZ & $-1.98750^{*}$ & .44856 & .000 & -3.2649 & -.7101 \\
\hline & & $\mathrm{FT}$ & $-1.58750^{*}$ & .44856 & .005 & -2.8649 & -.3101 \\
\hline & & RA & $-1.48750^{*}$ & .44856 & .011 & -2.7649 & -.2101 \\
\hline & Uncertified & $4 C$ & $1.01250^{*}$ & .23749 & .000 & .3362 & 1.6888 \\
\hline \multirow[t]{3}{*}{ cooperatives/KUBEs } & & UTZ & $1.93750^{*}$ & .23749 & .000 & 1.2612 & 2.6138 \\
\hline & & $\mathrm{FT}$ & .58750 & .23749 & .144 & -.0888 & 1.2638 \\
\hline & & RA & $.68750^{*}$ & .23749 & .043 & .0112 & 1.3638 \\
\hline
\end{tabular}

*. The mean difference is significant at the 0.05 level.

The second implication regards the hypothesis on socio-demographic explanations for participation in certification (hypothesis 2). We found that farm size and non-coffee income indeed explain the decision to participate. As indicated by the coefficients in Table 15 above, farm size has a positive influence on the participations, whereas noncoffee income has a negative influence. This means that farmers owning larger farms and having less non-coffee income are likely to join a certification program. All other variables mentioned in the hypothesis (age and education) do not significantly influence the decision to participate. The Anova results (Table 16 above) further reveal that 
farmers participating in Fairtrade (FT) own significantly larger farms (2.75 hectares on average) than 4C farmers (1,38 hectare), Utz certified (1.41 hectare), Rainforest Alliance (1.66 hectare), and uncertified producers (1.59 hectares). Therefore, we conclude that farm size mainly seems to (partially) explain the participation of FT farmers.

The third implication refers to the attitudinal explanations (third hypothesis). The results show that a risk-taking attitude positively relates to the participation decisions. Environmental attitude, opportunistic behavior, seeking information and openness to discussion to increase knowledge, however, do not significantly influence these decisions. All certified farmers have a significantly more positive attitude toward risktaking than uncertified producers. This finding is supported by the Anova test ( $p$-values are all below 0.05). Since this variable was measured by asking four related questions (see Appendix 4) we summed-up the scores of these questions and therewith obtained average mean scores of 12.6 and 10.9 for the certified and uncertified farmers respectively. Hence, farmers with a risk-taking attitude are more likely to participate in sustainable coffee certifications than farmers with a more risk-aversive attitude.

The final implication relates to the institutional explanation (hypothesis 4). Embeddedness in well-functioning farmer groups does significantly influence the farmer's decision to participate. Also the distance to these cooperatives/KUBEs does play a significant role in farmer's participation in certification. The Anova test shows that the distance to cooperatives/KUBEs does not significantly differ between FT farmers and uncertified producers. The other certified farmers, do significantly differ from the uncertified farmers on this respect. This means that distance matters in the decision to participate, but not for the FT farmers. Thus, farmers who are embedded in well-functioning farmer groups and who live relatively close to the organizations are likely to join certification programs (the latter with the exception of FT farmers).

If we look at the relative importance of the variables explaining the decision to participate in certification schemes, we see that the prospect of a price premium (coefficient $=0.957$ ) is the most important variable, followed by farm size (coefficient=0.955), distance to the cooperative or KUBE (coefficient=-0.536), the prospect of increased productivity (coefficient=0.424), avoidance of "playing it safe" (coefficient=0.282), embeddedness in well-functioning farmer groups (coefficient=0.204) and non-coffee income (coefficient=-0.056). This implies that, from the four presented explanations, the economic explanation is the most important one with a total coefficient value of 1.381, followed by the socio-demographic explanation with a coefficient value of 0.899 , the institutional explanation (coefficient=-0.332), and the attitudinal explanation (coefficient $=0.282$ ). This means that participation in the 
sustainability standards is influenced by farm size, non-coffee income, risk-taking attitude, embeddedness in well-functioning farmer groups, and distance to cooperatives or KUBEs. However, the main reasons for the farmers to join the standards are their expectations about economic gains.

Our results lead to a reformulation of the earlier defined hypotheses:

H1: $\quad$ Farmers who perceive that joining certification is ideally needed for obtaining a price premium and to increase productivity are likely to join sustainability coffee certifications.

H2: $\quad$ Farmers who own larger farms and who earn less non-coffee income are likely to join sustainability coffee certifications. The large farm size is particularly powerful to explain participation in the FT scheme.

H3: Farmers with a risk-taking attitude are likely to join sustainability coffee certifications.

H4: $\quad$ Farmers who are embedded in a well-functioning farmer group and who live relatively close to cooperatives or KUBES are likely to join sustainability coffee certifications. Distance seems to play a less important role to explain the decision to participate in FT.

The adjusted standard error for the final regression is sigma $=0.634$ and the correlation coefficient between the unobservables in step 1 and 2 equals rho=0.781. As rho is positive, this implies that selection bias may cause some inconsistency of the results if they would not be corrected by the Heckman's method. The estimated selection coefficient Mils lambda equals (sigma $\times$ rho $=0.634 \times 0.781$ ) 0.495 and is significant $(p=0.041)$. This suggests that (unobserved) variables influence the farmers' decision to join certification. More variables than the ones included in our hypotheses can therefore said to play a role in farmer's decision to participate in certification schemes. Preliminarily, and based on the interviews with the farmers, we argue that these variables may include the influence of relatives and middlemen, as well as exposure to outside information the smallholders have. Advice from relatives, fellow farmers, families, and neighbors may significantly influence the farmers' decision to participate. Next, as farmers often borrow money from the middlemen, they are expected to sell their coffee to these middlemen to pay their debts. This type of relationship may have a strong effect on the farmer's decision not to participate in certifications. The exposure to external information refers to the profundity of experiences that the farmers have regarding people and things from outside their neighborhood, and also reflects the amount of information they receive from the outside. For example, frequent visits to 
other towns, markets, and other farms, as well as listening to the radio and watch television may increase the exposure to outside information, which may positively influence the attitude towards external certification schemes and the decision to participate.

\subsection{Conclusion}

The Indonesian coffee sector is characterized by a large number of smallholders and various Northern-based sustainability standards and certification schemes. Despite the scheme's potential contribution to a more sustainable coffee production, most Indonesian coffee smallholders do not participate in these certifications. Current literature offers competing explanations regarding the decision of farmers to participate in coffee certifications. With our analysis, we contribute to this literature by evaluating the relative importance of the explanations from the perspective of Southern producers, particularly Indonesian smallholders.

Our results reveal that economic motivations are the strongest explanatory factor behind farmer participation in certification, followed by the socio-demographic explanation, the institutional explanation, and the attitudinal explanation. Within the economic explanation, the prospect of a price premium is crucial in a farmer's decision to join certification.

The results reveal differences between certified and uncertified farmers in their motivation to join certification or not. The certified farmers for example, had a significant higher expectation about the receipt of a price premium and increased productivity (i.e., economic explanation) compared to the uncertified farmers. Likewise, certified farmers were found to have a significantly more positive attitude towards risktaking than uncertified producers. Some variables such as farm size and distance to cooperative/KUBE are only significantly different between the certified FT farmers and uncertified producers.

We also found that some explanatory variables for joining certification differ among the schemes. For example, UTZ and RA farmers did not expect their productivity to be increased through certification, whereas other certified farmers decided to join certification partly because of their expectation for a higher productivity. Such differences make it difficult to develop a blue print for explaining participation.

Our results may have some implications for certification practices. First, while the prospect of a price premium turned out to be vitally important for a farmer's decision to participate, our interviews revealed that certified farmers do not always receive a price premium for their certified coffee. In the cases they did receive a price premium, the price differential with non-certified coffee is very small (also see Astuti et al., 2015). This 
not only discourages the uncertified farmers to join, but also demotivates the certified producers to stay in the programs. If challenges regarding the receipt of a price premium cannot be solved, it may be hard to include more farmers in the certification schemes and certification might even lose its relevance to farmers over time. Second, participation in FT certification is more difficult for smallholders who own smaller plots and who live further away from KUBEs. From a sustainability point of view however, targeting the most vulnerable smallholders (with often very small plots and struggling to survive economically) may be prioritized over the relatively larger smallholders. Third, it is remarkable that UTZ certified, and RA farmers did, prior to being certified, not expect their productivity to increase through certification. As is shown by Astuti et al. (2015), coffee certification does however lead to significantly higher productivity for Indonesian farmers. This raises questions about the information and communication strategies of certification schemes towards prospectively certified farmers. Our results indicate that is it not unlikely that different schemes adopt different communication strategies, influencing the farmer's decision to adopt.

Finally, we reflect on the limitations of our study. First, our decision not to analyze prospective farmers (but farmers who made a decision to adopt or not in the nearby past) may have offered challenges for farmers to access their memories regarding past decisions accurately. Also, the possible effects of certification on the farmer's explanations for participation cannot be entirely ignored. Next, we have seen that not all of farmers' decisions to participate can be explained by the variables in our model. This means there are more variables that play a role in farmer's participation decisions. To include more variables, and add more rigors to our method it would be essential to increase the number of respondents significantly. Future studies should also consider (unobserved) variables that work as selection mechanism and may significantly influence farmer participation such as buyer preferences, pre-existing buyer-producer relations, and the structures of farmer organizations. 



\section{Chapter}

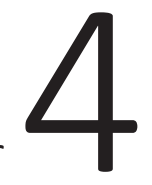

\section{Perceived impacts of certification and farmer organization: benefits from the Indonesian smallholders' point-of-view}

This chapter is based on:

Ibnu, M., Offermans, A., \& Glasbergen, P. (forthcoming). Perceived impacts of certification and farmer organization: benefits from the Indonesian smallholders' point-of-view. Submitted to Bulletin of Indonesian Economic Studies. 


\subsection{Introduction}

Sustainability standards and certification are regarded as tools to improve smallholders' livelihood conditions and position in the market, and to enhance sustainability of the coffee production (Giovannucci \& Ponte, 2005). Research on the actual impacts of certification is however, rather inconclusive. Some studies mainly assign negative impacts to certification, for example, in terms of productivity and lower yields, increased cost, declining prices over time, and less satisfaction on organizational service provision (Carlson \& Palmer, 2016; Ibanez \& Blackman, 2016; Ruben \& Fort, 2012; Valkila, 2009; van Rijsbergen et al., 2016). Other studies however, mainly find positive impacts resulting from certification including higher prices, better productivity and coffee quality, better education and improved capacity building, better sanitation and networking, and enhanced organizational capacities (Astuti et al., 2015; Bacon, 2005; Bacon et al., 2008; De Lima et al., 2005; Giovannucci et al., 2008; Reynolds et al., 2004; Ruben \& Zuniga, 2011). These contrasting findings imply that the actual benefits of certification are still ambiguous and therefore worthwhile to further explore. Here it is important to realize that research on farmer benefits from certification occurs in Indonesia at a crossroad of research on certification and organization.

Indonesian coffee smallholders cannot become certified without being organized (Loconto \& Dankers, 2014) and farmer organizations have been promoted as important means for linking smallholders to global certified coffee markets. Organizations are believed to bring a form of collective action (e.g., internal group monitoring and training) that is essential to smallholders' participation in certification (Narrod et al., 2009). Farmer organizations make the certification of smallholders economically feasible through offering economies of scale (Maertens \& Swinnen, 2009; Mausch et al., 2009) and reducing the transaction costs of service providers working with smallholders (Thorp et al., 2005). Certification schemes therefore connect to farmer organizations rather than to individual farmers, also because the latter is considered inefficient given the large number of farmers and the farmers' variation in terms of financial opportunities, knowledge, and skills. Variations and individual limitations can be overcome by encouraging farmers to organize and work together. As membership of a farmer organization has become de facto mandatory for smallholders to become certified (Brandi et al., 2013; Pierrot et al., 2010), it is impossible to clearly distinguish between effects of certification on the one hand and effects of organization on the other hand. Further, and even though the literature tends to generalize farmer organizations, their manifestations are diverse. Therefore, they cannot be analyzed or compared as homogeneous entities. In Indonesia, for example, we observe three types of farmer organizations that play a role in the coffee sector: farmer groups, cooperatives and KUBEs. These organizations have different organizational 
characteristics since they were initiated and are managed by different ministries with different sets of rules.

In this paper, we do not apply an empirical measurement of actual impacts of certification in the field, but instead focus on the perception of benefits by smallholders. This differs from previous studies that evaluated actual impacts in the field with robust longitudinal panel data or with case studies (see Carlson \& Palmer, 2016; Ibanez \& Blackman, 2016; van Rijsbergen et al., 2016). We focus on the Indonesian coffee sector and analyze farmers' perceived benefits resulting from participating in the different types of farmer organizations and in certification schemes. Our research, therefore, draws from two strands of literature: certification literature focusing on evaluating farmers' benefits from participation in certification (see for example Bray et al., 2002; Raynolds et al., 2004; Taylor et al., 2005), and organization literature focusing on farmers' benefits of organization (e.g., Fischer \& Qaim, 2012; Hellin et al., 2009; Kaganzi et al., 2009; Markelova et al., 2009). Although both strands of literature are rather rich in investigating and explaining the impacts/benefits of either certification or organization on farmer welfare and livelihood, there are very few studies that consider and further question farmers' perceptions of the benefits. We consider perceptions as important because they significantly determine farmers' satisfaction that influences whether the farmers continue their participation in certification or not (Bravo et al., 2012). Furthermore, the existing literature largely fails to comprehensively understand potential benefits along different domains and the extent to which perceived benefits differ for farmers belonging to different organizational forms or coffee certification schemes.

This paper contributes to knowledge as to whether farmers participating in different certification schemes and in different organizational structures perceive (different) benefits in relation to different benefit domains. The paper addresses the following research questions:

1. How do different forms of Indonesian farmer organizations differ and how do they relate to certification?

2. How do differences in perceived benefits relate to membership of different organizations and certification schemes?

3. What do the findings imply for a more sustainable coffee production from a smallholders' point-of- view? 
This paper is structured as follows; in the next sections, we provide a literature review on potential benefits of farmer organization and certification, including an overview of a division of potential benefits in five domains and farmer organizations in Indonesia. We propose hypotheses on the influence of organizations and certification schemes on perceived benefits. In section three we describe our methods and we provide an overview of our respondents. In section four we present our results, followed by the conclusions and reflection in section five.

\subsection{Literature review on potential benefits of farmer organization and certification}

Although not specifically considering the role of certification, the literature is rather rich in presenting the benefits of farmer organizations. These benefits vary widely and differ from better job opportunities (Jena et al., 2015; Place et al., 2004; van Rijsbergen et al., 2016), to improved skills (Bitzer et al., 2013; Neilson, 2008; Ruben \& Zuniga, 2011; Utting, 2008), and from better bargaining power (Bacon, 2010; Taylor et al., 2005) to better networking opportunities (Taylor et al., 2005; Raynolds et al., 2004). For this paper, we divide these benefits for farmers in 5 domains. First, economic benefits such as saving costs through collective marketing, better prices for their products, better access to inputs and production facilities, more secure land tenure, better access to credits, and the provision of options for saving money. Second, social or community benefits in the form of better education, health and housing services, access to public facilities (e.g. safe drinking water and sanitation), support for organizing social events, strengthened social relations among community members, and providing jobs. Third, benefits in the domain of representation as organizations may represent farmers in formal meetings, and negotiate their interests with external parties such as the government or firms. Fourth, benefits in the domain of capacity building referring to improved knowledge and skills, for example through training, the provision of information and technical support, and encouraging participation in decision making (Bitzer et al., 2013; Neilson, 2008; Ruben \& Zuniga, 2011; Utting, 2008). Fifth, we identify benefits in terms of networking, often taking the form of collaborating with other organizations (like private companies) to enhance financial capital and secure market access.

Some of these benefits, however, are not only associated with farmers' membership of an organization, but also with their participation in certification. In the domain of economic benefits, for example, certified farmers are found to obtain higher prices for their coffee (Astuti et al., 2015; Bacon, 2005), to have a higher productivity and a better coffee quality compared to conventional farmers (Astuti et al., 2015; Ruben and Zuniga, 2010). Certification may further bring social benefits such as improved education and sanitation (De Lima et al., 2005) and is also found to play a role in improving capacity 
building (Reynolds et al., 2004), enhancing organizational capabilities (Ruben and Zuniga, 2010), and improving networking capacities (Bacon et al., 2008).

In the literature it is also assumed that assets and/or (financial) capital influence an organization's ability to provide services (e.g., cash payment, credit etc.) that in turn influence its members' perceived benefits (Chandler \& Hanks, 1998; Holagh et al., 2014). As such, organizations with larger assets and/or capital may create higher perceived benefits than organizations with lesser assets and/or capital.

Furthermore, certification schemes tend to focus on, or prioritize, different aspects of a sustainable coffee production. Fair Trade (FT), for example, concentrates on improving the social aspects of coffee production whereas Utz-certified (UTZ) focuses on farm efficiency and coffee traceability (Auld, 2010). Rainforest Alliance (RA) gives strong attention to environmental aspects (Kilian et al., 2004), whereas 4C is often portrayed as a less strict scheme not emphasizing any particular dimension of sustainable development (Bitzer et al., 2008). The question that will be answered in this paper is whether farmers participating in different schemes also experience different benefits.

Based on the certification and organization literature referred to above, we developed three hypotheses:

Hypothesis 1 : Farmers participating in the more demanding schemes (RA, UTZ, $F T)$ perceive more benefits than farmers participating in a less demanding scheme (4C)

Hypothesis 2 : Farmers participating in organizations with larger assets and/or capital perceive more benefits than farmers participating in organizations with fewer assets and/or capital.

Hypothesis 3 : Certified and organized farmers perceive more benefits than uncertified or unorganized farmers.

\subsection{The landscape of farmer organizations in Indonesia}

Organizations can be defined as intelligent systems in which groups of people deliberately cooperate with each other in order to achieve shared goals (Holagh et al., 2014). Individual smallholders participate in farmer organizations to achieve these shared goals in the form of benefits. In the Indonesian coffee sector we distinguish three types of farmer organizations: farmer groups, cooperatives and KUBEs. 


\section{Farmer groups}

In Indonesia, farmer groups were initiated by the central government in 1979 with the aim to facilitate the distribution of governmental aid to the farmers, and, as from 2001, to negotiate about the utilization of protected forests for coffee production (Arifin, 2010). Farmer groups have a formal status in the country (Nuryanti \& Swastika, 2011), and are currently regulated by the Ministry of Agriculture. According to the ministry's regulations, a farmer group is defined as a group of farmers formed on the basis of mutual interest, similarity in commodities, and geographical closeness (Permentan RI No. 82, 2013). On average, a farmer group consists of 30 individual members who mostly live in the same village. The main functions of a farmer group regard the enhancement of cooperation among farmers, the facilitation of learning processes, and the distribution of tools, farming inputs, and credits from the government to farmers. Cooperation between farmers in a farmer group may result in achieving economies of scale, improved coffee quality and, by providing equipment, help the members to process their coffee cherries. We see that certified Indonesian coffee farmers commonly have a dual organizational membership in which their membership of a farmer group is either combined with a KUBE or a cooperative. Uncertified farmers may be part of a farmer group, but not of a KUBE or cooperative. They commonly connect to conventional channels involving middlemen and local traders (see Astuti et al., 2015).

The establishment of a farmer group requires the participation of smallholder farmers, the village leader, community leaders, and agricultural extension officers. The members need to develop and present a formal agreement, which needs to be signed by (representatives of) the different member groups. The management of a farmer group consists of a group leader, a secretary, and a treasurer; any changes to the managerial structure need to be approved by the village leader and acknowledged by agricultural extension officers (Permentan RI No. 82, 2013). There is no need for farmers to contribute individual assets to a farmer group although some (financial) contributions are usually applied. As a non-legal entity, a farmer group may largely depend on supports from, for example, the government to build its initial assets and/or capital.

\section{Cooperatives}

Cooperatives are developed based on the principles stated in the Indonesian Cooperative Law to increase economies of scale, to improve production efficiency, and to enhance the bargaining position of its members (UU RI No. 25, 1992). In practice, we see that cooperatives often facilitate farmers in buying inputs and that they provide credits to coffee producers. According to the law, a cooperative is founded by at least twenty individuals who contribute some of their wealth to the initial capital of the 
organization. Their agreement to form a cooperative must be drawn up by a notary and legalized by the Ministry of Cooperative. A cooperative therefore has authorized rights and responsibilities, but can also be sanctioned if the organization performs against the law.

The management of a cooperative comprises of a general assembly, a board of directors, an audit committee, and an election committee. The assembly represents the highest policy making body and meets at least once a year to decide the organization's policies and select the board of directors and the committees. A cooperative generally prioritizes democratic decision making through voting, although the assembly mostly tries to reach consensus. Different from other organizational types, income generated by cooperatives (for example resulting from trading activities) must be equally shared among all members. As a legal entity, cooperatives are entitled to increase their assets and/or capital by obtaining loans from various sources (e.g., banks, private creditors, other cooperatives etc.), or by issuing obligations (UU RI No. 25, 1992). Therefore, cooperatives are generally more asset and capital rich than the other organizations in the Indonesian coffee context. Legally, farmers do not have to join farmer groups to become members of cooperatives although, in practice, most cooperative members also join farmer groups. This is largely to enable them to also claim (governmental) support (e.g., tools, fertilizers, pesticides etc.) and to participate in governmental programs in rural areas.

\section{KUBES}

KUBEs (Kelompok Usaha Bersama) or Joined Business Groups have been initiated by the Indonesian Ministry of Social Affairs as from 1983 to support the regulations on welfare services for the poor (PP RI No. 42, 1981). The underlying idea of the development of KUBEs was to strengthen existing micro businesses ${ }^{19}$ by integrating them into larger business ventures. KUBEs may differ in their size. Conceptually, a small KUBE is a collaboration of five to seven micro businesses that agree to merge their available assets. Medium and large KUBEs consist of eight to fifteen, and sixteen to thirty micro businesses respectively. KUBEs are generally smaller than cooperatives in term of their assets and/or capital, and mostly pay their farmers after receiving their payment from buyers/exporters whereas cooperatives, if required, can pay their farmers in advance (Ibnu et al., 2015). KUBEs are also considered as non-legal entities and therefore, unlike

\footnotetext{
${ }^{19}$ A micro business is defined as a business owned by an individual or a group with assets up to 50 million Rupiahs (or less than 4000 US dollars) in total (UU RI No. 20, 2008).
} 
cooperatives, they much depend on the contributions of their owners for assets and/or capital, or support from external parties, particularly the government.

KUBEs take care of cleaning, drying, and transporting coffee beans from farmer groups to the roasting companies (in the case of conventional coffee) or exporters (for certified coffee) (Ibnu et al., 2015). Different from cooperatives, KUBEs always connect to individual farmers through farmer groups (Ibnu et al., 2015). This means that KUBEs require individual farmers to firstly organize themselves in farmer groups. To be formally acknowledged by the national government and to be entitled to receive additional capital investments from the Ministry of Social Affairs, KUBEs must be verified by leaders at the village and sub-district levels (Haryati, 2013; Suradi, 2012).

\subsection{Methods}

We used semi-structured questionnaires to randomly survey certified and conventional coffee farmers in the Indonesian provinces of Lampung (i.e., Tanggamus and West Lampung Districts) and Aceh (i.e., Central Aceh and Bener Meriah Districts). Lampung contributes $23.6 \%$ to the national Robusta production whereas Aceh contributes 25\% to the national Arabica production (Dirjen Perkebunan, 2014). In the study sites, certified Arabica farmers mostly register at cooperatives and participate in Fairtrade (FT) schemes whereas certified Robusta farmers typically register at KUBEs and Utz, Rainforest Alliance (RA), or 4C. In the field - and corresponding with what we presented above-we found that most certified farmers have a dual organizational membership that either combines participation in farmer groups with KUBEs (FGKUBE) or with cooperatives (FGcooperative) (see Table 17 below). Uncertified farmers either participate in a farmer group (IFG) or act fully independently (without organizational membership). From various villages, we indiscriminately selected 14 farmer groups that have affiliations with five KUBEs and three cooperatives. We then randomly distributed the questionnaires to 80 certified farmers who are members of the selected farmer groups. Together with the 80 uncertified smallholders our total sample equals 160 respondents that can further be grouped into: independent and uncertified farmers $(\mathrm{N}=50)$, certified farmers with dual organizational memberships $(\mathrm{N}=80)$, and uncertified farmers with single organizational membership $(\mathrm{N}=30)$. The uncertified farmers were surveyed in the same regions (but in different villages) as the certified farmers. Table 17 presents the respondents. 
Perceived impacts of certification and farmer organization: benefits from the Indonesian smallholders' point-of-view

Table 17. Types of respondents, based on participation in certification and group membership

\begin{tabular}{|c|c|c|c|c|c|}
\hline \multicolumn{2}{|c|}{ Type of respondents } & \multirow[t]{2}{*}{ Schemes } & \multirow[t]{2}{*}{$\mathrm{N}$} & \multicolumn{2}{|c|}{$\begin{array}{l}\text { Average length of } \\
\text { participation }\end{array}$} \\
\hline & & & & $\begin{array}{c}\ln \\
\text { organization }\end{array}$ & $\begin{array}{l}\ln \\
\text { certification }\end{array}$ \\
\hline \multirow{4}{*}{$\begin{array}{l}\text { Certified } \\
\text { smallholders }\end{array}$} & Members of FGKUBE & $4 \mathrm{C}$ & 20 & 5.4 years & 3.0 years \\
\hline & & UTZ & 20 & 7.4 years & 5.6 years \\
\hline & & RA & 20 & 6.9 years & 5.7 years \\
\hline & Members of FGcooperative & FT & 20 & 8.2 years & 7.8 years \\
\hline \multirow[t]{2}{*}{$\begin{array}{l}\text { Uncertified } \\
\text { smallholders }\end{array}$} & $\begin{array}{l}\text { Members of (independent) farmer } \\
\text { group (IFG) }\end{array}$ & - & 30 & 7.6 years & - \\
\hline & $\begin{array}{l}\text { Independent smallholders } \\
\text { (unorganized) }\end{array}$ & - & 50 & - & - \\
\hline \multicolumn{3}{|c|}{ Total respondents } & 160 & & \\
\hline
\end{tabular}

To answer the first research question, we determined (general) organizational characteristics based on the government's rules and regulations for the organizations such as Permentan RI No. 82 year 2013 (farmer groups), UU RI No. 25 year 1992 (cooperatives), and PP RI No. 42 year 1981 and UU RI No. 20 year (KUBEs). We then had open discussions with farmers, ICS $^{20}$ (internal control system) personnel of the certification schemes, and staff members of cooperatives and KUBEs. The aim of these discussions was to get a complete and verified overview of the characteristics of the different types of organization. We discussed organizational characteristics such as administration, focus of activities and orientation, decision making processes, leadership, membership, and information flow.

To answer the second research question, we operationalized the five domains of perceived benefits in question items. For example, perceived economic benefits are operationalized by asking farmers whether it is easy to sell their coffee, or to access input, savings and credit, and whether they consider the price for their coffee to be fair. All question-items are directly derived from the literature (see Appendix 5) and presented on a five-point-Likert-scale, ranging from 1 (strong disagreement towards perceiving the mentioned benefit) to 5 (strong agreement). We use a t-test to analyze whether differences in perceived benefits correspond to differences in organizational membership status (i.e., unorganized versus organized smallholders) and participation in certification (i.e., uncertified versus certified farmers). We use a One Way Anova test to further analyze whether different organizational memberships (i.e., IFG, FGKUBE and FG cooperative) or participation in different schemes (i.e., 4C, UTZ, FT, and RA certified)

${ }^{20}$ ICS staff is hired by cooperatives and KUBEs to work as private extension officer to help farmers (mostly by trainings) to comply with the certification requirements. 
significantly contribute to differences in perceived benefits. We also applied an ordinal logistic regression model for each domain of perceived benefits (i.e. five in total) to gain knowledge on the extent to which organization, certification and demographic variables explain variation in perceived benefits. Literature shows that demographic variables such as age, education, family size, experience in farming, and landownership may explain variation in farmer perceptions (see for example Adesina \& Baidu-Forson, 1995; Sherrick, et al., 2004; Somda et al., 2002; Wheeler, 2008). We will test whether this is also the case for farmers' perceptions of benefits through the inclusion of these variables in our regression model. In our ordinal logistic model, the perceived benefits are explained through participation in certification, organizational membership, age (in years), education (in years), family size (number of people in a household), experience in farming (in years), and landownership (in hectares).

\section{Table 18. Test of Parallel Lines}

\begin{tabular}{|c|c|c|c|c|c|}
\hline Perceived benefit & Model* & -2 Log Likelihood & Chi-Square & $\mathrm{df}$ & Sig. \\
\hline \multirow[t]{2}{*}{ Economic } & Null Hypothesis & 569.968 & & & \\
\hline & General & 517.400 & 52.567 & 77 & 0.985 \\
\hline \multirow[t]{2}{*}{ Social/Community } & Null Hypothesis & 591.909 & & & \\
\hline & General & 519.012 & 72.897 & 91 & 0.918 \\
\hline \multirow[t]{2}{*}{ Representation and/or negotiation } & Null Hypothesis & 506.194 & & & \\
\hline & General & 463.147 & 43.048 & 49 & 0.712 \\
\hline \multirow[t]{2}{*}{ Capacity building } & Null Hypothesis & 542.581 & & & \\
\hline & General & 512.209 & 30.372 & 77 & 1.000 \\
\hline \multirow[t]{2}{*}{ Networking and/or partnership } & Null Hypothesis & 535.675 & & & \\
\hline & General & 468.006 & 67.669 & 56 & 0.137 \\
\hline
\end{tabular}

* The null hypothesis states that the location parameters (slope coefficients) are the same across response domains and can be confirmed if the P-value is equal to, or higher than 0.05

To quantify the composite dependent variable of perceived benefits, we summed up farmers' responses, resulting in $\mathrm{N}=160$ different scores per benefit domain. The higher the score, the more the farmer agrees that benefits are perceived in the respective domain. In theory, the scores could vary between 3 (three times a score of one in the domain of networking) and 75 for the domain of social benefits (covering 15 items that could in theory all be answered with a five). The results indicate that the width of potential scores is covered relatively well as the scores fluctuate between 6 (for networking) and 70 (for social benefits). We treat each sum of scores as ordinal. We justify this choice by using the test of parallel lines that is based on different chi-square tests and assesses whether there are (undesirable) significant differences in the coefficients (see Brant, 1990). Table 18 above shows the results of the test of parallel lines and reveals that all domains of perceived benefits have P-values (substantially) exceeding 0.05 . This means that there are no significant differences in the coefficients, indicating that the distances between the ordinal scores can be considered the same, justifying the treatment of the dependent variable as ordinal. 
The perceived benefits (i.e., independent variable) and organization and certification (dependent variables) are categorical (i.e. nominal). Therefore we used dummy codes as an input to the regression model. For organization, the dummy code 0 refers to independent smallholders and 1 to organized smallholders. For certification, a score of 0 represents the uncertified smallholders and 1 the certified smallholders. The strength of the influence of certification and organization on perceived benefits is shown by an estimate (i.e., the regression coefficient) in the regression model which needs to have a P-value of 0.05 or lower to be considered significant. The value of the estimate (positive or negative) reveals the direction of the influences of a predictor variable (either organization or certification) on the perceived benefits. The interpretation of the estimate is that for a one unit change in the predictor variable (moving from being unorganized towards being organized, or from being uncertified to certified), the benefits are expected to change by the value of its estimate. The higher the estimate the stronger the variable's contribution to the perceived benefits.

\subsection{Different organizations and their relation to certification}

Table 19 below presents the organizational characteristics of farmer groups, KUBEs, and cooperatives. Here we see that the different organizations share some similarities (for example, in their decision making procedures). The cooperatives tend to be most distinctive as they differ from the other two organizations in terms of administration and administrative sanctions, member participation in decision making, leadership style, membership type, funding source, and legal status. The farmer group differs from the other two organizations regarding their focus (on production only) and their orientation (inward oriented).

In practice, all certified farmers are members of FGs and either KUBEs or cooperatives. In the case of FT certification, all farmers become member of a FGCooperative. The interviews revealed that the $\mathrm{FG}^{\prime} \mathrm{s}$ connection with $\mathrm{KUBES} /$ cooperatives, being mandatory in certification, has improved the $\mathrm{FG}^{\prime} \mathrm{s}$ administration in terms of recording the quantity and prices of coffee sold to KUBEs/cooperatives. FGs also broadened their focus from production only, towards also supporting post-harvest and marketing activities, with the aim to deliver good quality beans as requested by the KUBEs/cooperatives. Some FGs characteristics are not influenced by the FG's relation with KUBEs and cooperatives. For example, FGs maintain their ways of recruiting new members, obtaining funding, and making decisions. FGs are also still considered nonlegal entities and cannot be confronted with legal sanctions for administrative failures. 
Chapter 4

Table 19. Organizational characteristics of farmer groups, KUBEs, and cooperatives

\begin{tabular}{|c|c|c|c|}
\hline $\begin{array}{l}\text { Organizational } \\
\text { characteristics }\end{array}$ & Farmer groups (FGs) & KUBES & Cooperatives \\
\hline Administration & $\begin{array}{l}\text { Rarely record financial } \\
\text { activities }\end{array}$ & $\begin{array}{l}\text { Starts to record cash- } \\
\text { flows }\end{array}$ & $\begin{array}{l}\text { Complete financial } \\
\text { report (audited if } \\
\text { requested) }\end{array}$ \\
\hline Administrative sanction & $\begin{array}{l}\text { No legal sanction for } \\
\text { administrative failure }\end{array}$ & $\begin{array}{l}\text { No legal sanction for } \\
\text { administrative failure }\end{array}$ & $\begin{array}{l}\text { Legal sanction for } \\
\text { administrative failure }\end{array}$ \\
\hline Focus of activities & Production activities & $\begin{array}{l}\text { Pre-harvest activities } \\
\text { and marketing }\end{array}$ & $\begin{array}{l}\text { Pre-harvest activities } \\
\text { and marketing }\end{array}$ \\
\hline Orientation & $\begin{array}{l}\text { Inward oriented (focus } \\
\text { on internal relationship) }\end{array}$ & $\begin{array}{l}\text { Starts to be outward } \\
\text { oriented }\end{array}$ & $\begin{array}{l}\text { Outward oriented } \\
\text { (connect to local buyers, } \\
\text { exporters, roasters etc.) }\end{array}$ \\
\hline Decision making & Consensus & Consensus & Consensus, if not voting \\
\hline $\begin{array}{l}\text { Member participation in } \\
\text { decision making }\end{array}$ & $\begin{array}{l}\text { Tends to be passive, } \\
\text { reliance on leader and } \\
\text { other colleague farmers }\end{array}$ & $\begin{array}{l}\text { Tends to be passive, } \\
\text { reliance on business } \\
\text { operator }\end{array}$ & $\begin{array}{l}\text { Tends to be active, right } \\
\text { to vote }\end{array}$ \\
\hline $\begin{array}{l}\text { Level of formality inside } \\
\text { the organization }\end{array}$ & Low & Low & High \\
\hline Leadership style & $\begin{array}{l}\text { Often centralize on } \\
\text { group leader }\end{array}$ & $\begin{array}{l}\text { Often centralized } \\
\text { around a business } \\
\text { operator }\end{array}$ & A general assembly \\
\hline Flow of information & $\begin{array}{l}\text { Mostly through } \\
\text { agricultural extension } \\
\text { officer and group leader }\end{array}$ & $\begin{array}{l}\text { Mostly through social } \\
\text { worker and business } \\
\text { operator }\end{array}$ & $\begin{array}{l}\text { Through member } \\
\text { meeting, supervisory, } \\
\text { and executive board }\end{array}$ \\
\hline Type of membership & $\begin{array}{l}\text { Exclusive (based on } \\
\text { many similarities such as } \\
\text { neighborhood, type of } \\
\text { farming, even ethnicity } \\
\text { and language) }\end{array}$ & $\begin{array}{l}\text { Rather exclusive } \\
\text { (restricted to those in } \\
\text { the nearby } \\
\text { neighborhood and } \\
\text { similarity of business } \\
\text { type) }\end{array}$ & $\begin{array}{l}\text { Inclusive (tries to include } \\
\text { many different types of } \\
\text { people from different } \\
\text { regions) }\end{array}$ \\
\hline Sources of funding & $\begin{array}{l}\text { Highly dependent on } \\
\text { internal sources (e.g., } \\
\text { member contribution) } \\
\text { and external sources } \\
\text { (i.e., government } \\
\text { funding) }\end{array}$ & $\begin{array}{l}\text { Internal sources } \\
\text { (members) but still } \\
\text { highly dependent on } \\
\text { additional capital from } \\
\text { government }\end{array}$ & $\begin{array}{l}\text { Independent, relies on } \\
\text { internal (members) and } \\
\text { external (private } \\
\text { creditors) funding }\end{array}$ \\
\hline Legal status & non-legal entity & non-legal entity & Legal entity \\
\hline
\end{tabular}

For cooperatives and KUBEs, certification requires management practices involving administrative tasks, such as updating a list with farmer profiles, tracking the quantity of coffee sold by every farmer to the organization, providing regular information on prices, and administering the price premium paid to farmers. Farmers realized that they no longer depend on group leaders for information but that they can also rely on ICS staff as source of information. Both certification and the dual group membership expand the farmers' base of information. In the next section, we elaborate on the perceived 
benefits influenced by organizational membership and participation in different certification schemes.

\subsection{The influence of organizations and certification schemes on perceived benefits}

Table 20 below shows the descriptive statistics of the mean scores for the perceived benefits in the five domains. If we compare the average scores with the maximum scores within each domain, we see that farmers in general perceive relatively high benefits in all domains (with an average score of 3.43 on a five-point-scale for all domains together). Differences between domains are small and vary between average scores of 3.3 for perceived benefits in the domain of networking, to a score of 3.5 for benefits in the domain of representation and capacity building. We further see that certified farmers perceive higher benefits than uncertified farmers in all benefit domains. Similarly, organized farmers perceive higher benefits, in all domains, compared to the unorganized smallholders. Overall, certified farmers have higher average benefits in all domains than the organized farmers. However, since in our sample farmers who are certified are also organized, we cannot further separate the effects of organization and certification on perceived benefits.

Table 20. The mean score of the perceived benefits

\begin{tabular}{|c|c|c|c|c|c|}
\hline Group & $\begin{array}{l}\text { Economic } \\
\quad(\max . \\
\text { Score }=45)\end{array}$ & $\begin{array}{c}\text { Social/ } \\
\text { community } \\
\text { (max. Score } \\
=75)\end{array}$ & $\begin{array}{l}\text { Representation } \\
\text { and/or } \\
\text { negotiation } \\
\text { (max. Score } \\
=20 \text { ) }\end{array}$ & $\begin{array}{l}\text { Capacity } \\
\text { building } \\
\text { (max. Score } \\
=55 \text { ) }\end{array}$ & $\begin{array}{l}\text { Networking } \\
\text { and/or } \\
\text { partnership } \\
\text { (max. Score } \\
=15 \text { ) }\end{array}$ \\
\hline \multicolumn{6}{|l|}{$\begin{array}{l}\text { Participation in } \\
\text { certification }\end{array}$} \\
\hline $\begin{array}{l}\text { Uncertified } \\
\text { smallholders }\end{array}$ & 26,625 & 44,375 & 12,075 & 32,900 & 8,875 \\
\hline Certified smallholders & 36,062 & 59,987 & 16,212 & 44,850 & 12,087 \\
\hline \multicolumn{6}{|l|}{ Organizational status } \\
\hline $\begin{array}{l}\text { Independent } \\
\text { smallholders }\end{array}$ & 23,100 & 38,500 & 10,600 & 28,600 & 7,700 \\
\hline $\begin{array}{l}\text { Organized } \\
\text { smallholders }\end{array}$ & 35,091 & 58,400 & 15,754 & 43,545 & 11,745 \\
\hline \multicolumn{6}{|l|}{ Certification schemes } \\
\hline FT certified & 36,750 & 61,250 & 16,35 & 45,350 & 12,250 \\
\hline 4C certified & 40,950 & 60,000 & 18,300 & 44,550 & 13,650 \\
\hline UTZ certified & 30,550 & 68,250 & 16,050 & 39,900 & 12,000 \\
\hline RA certified & 36,000 & 50,450 & 14,150 & 49,600 & 10,450 \\
\hline \multicolumn{6}{|l|}{ Form of organizations } \\
\hline IFG & 32,500 & 54,167 & 14,533 & 40,067 & 10,833 \\
\hline FGcooperative & 36,750 & 61,250 & 16,350 & 45,350 & 12,250 \\
\hline FGKUBE & 35,833 & 59,567 & 16,167 & 44,683 & 12,033 \\
\hline
\end{tabular}


Table 21 and 22 below show the results of the t-test for certification and organization respectively. Table 21 shows that the mean scores of certified and uncertified smallholders differ significantly (sig. 0.000) in all benefit domains. Certified farmers perceive significantly higher benefits than uncertified farmers. Table 22 reveals that the mean scores in all benefit-domains are considerably higher for organized farmers than for unorganized smallholders (sig. 0.000), implying that the organized farmers perceive considerably higher benefits than the unorganized smallholders. If we compare the relative differences in mean-scores as presented in Table 21 and 22, we see that farmers evolving from unorganized to organized are likely to perceive a more profound increase in benefits compared to farmers evolving from uncertified to certified, although the latter will also experience an increase in benefits. This result is probably influenced by the perception of uncertified but organized farmers (IFG farmers, $N=30$ ) who feel the organization (FG) provides benefits for them.

Table 21. Independent sample t- test for equality of means (participation in certification)

\begin{tabular}{|c|c|c|c|c|c|c|c|c|}
\hline \multirow[t]{2}{*}{$\begin{array}{l}\text { Perceived } \\
\text { benefits }\end{array}$} & \multirow[b]{2}{*}{$\mathrm{t}$} & \multirow[b]{2}{*}{ df } & \multirow{2}{*}{$\begin{array}{l}\text { Sig. } \\
(2- \\
\text { tailed })\end{array}$} & \multirow{2}{*}{$\begin{array}{c}\text { Mean } \\
\text { Difference }\end{array}$} & \multirow{2}{*}{$\begin{array}{c}\text { Relative } \\
\text { Mean } \\
\text { Difference }\end{array}$} & \multirow{2}{*}{$\begin{array}{l}\text { Std. Error } \\
\text { Difference }\end{array}$} & \multicolumn{2}{|c|}{$\begin{array}{l}\text { 95\% Confidence } \\
\text { Interval of the } \\
\text { Difference }\end{array}$} \\
\hline & & & & & & & Lower & Upper \\
\hline Economic & $-10,794$ & 157,319 & 0,000 & $-9,437$ & 20.8 & 0,874 & $-11,164$ & $-7,710$ \\
\hline $\begin{array}{l}\text { Social/ } \\
\text { community }\end{array}$ & $-10,800$ & 157,594 & 0,000 & $-15,612$ & 20.8 & 1,445 & $-18,467$ & $-12,757$ \\
\hline $\begin{array}{l}\text { Representation } \\
\text { and/or } \\
\text { negotiation }\end{array}$ & $-10,898$ & 157,129 & 0,000 & $-4,137$ & 20.5 & 0,379 & $-4,887$ & $-3,387$ \\
\hline $\begin{array}{l}\text { Capacity } \\
\text { building }\end{array}$ & $-11,412$ & 157,875 & 0,000 & $-11,950$ & 21.6 & 1,047 & $-14,018$ & $-9,882$ \\
\hline $\begin{array}{l}\text { Networking } \\
\text { and/or } \\
\text { partnership }\end{array}$ & $-11,019$ & 157,308 & 0,000 & $-3,212$ & 21.3 & 0,291 & $-3,788$ & $-2,637$ \\
\hline
\end{tabular}

Table 22. Independent sample t- test for equality of means (participation in organization)

\begin{tabular}{|c|c|c|c|c|c|c|c|c|}
\hline \multirow[t]{2}{*}{$\begin{array}{l}\text { Perceived } \\
\text { benefits }\end{array}$} & \multirow[b]{2}{*}{$\mathrm{t}$} & \multirow[b]{2}{*}{$d f$} & \multirow{2}{*}{$\begin{array}{l}\text { Sig. } \\
(2- \\
\text { tailed })\end{array}$} & \multirow{2}{*}{$\begin{array}{c}\text { Mean } \\
\text { Difference }\end{array}$} & \multirow{2}{*}{$\begin{array}{c}\text { Relative } \\
\text { Mean } \\
\text { Difference }\end{array}$} & \multirow{2}{*}{$\begin{array}{l}\text { Std. Error } \\
\text { Difference }\end{array}$} & \multicolumn{2}{|c|}{$\begin{array}{l}\text { 95\% Confidence } \\
\text { Interval of the } \\
\text { Difference }\end{array}$} \\
\hline & & & & & & & Lower & Upper \\
\hline Economic & $-18,950$ & 156,641 & 0,000 & $-11,991$ & 26.4 & 0,633 & $-13,241$ & $-10,741$ \\
\hline $\begin{array}{l}\text { Social/ } \\
\text { community }\end{array}$ & $-19,044$ & 156,201 & 0,000 & $-19,900$ & 26.5 & 1,045 & $-21,964$ & $-17,836$ \\
\hline $\begin{array}{l}\text { Representation } \\
\text { and/or } \\
\text { negotiation }\end{array}$ & $-18,117$ & 155,120 & 0,000 & $-5,154$ & 26.0 & 0,284 & $-5,716$ & $-4,592$ \\
\hline $\begin{array}{l}\text { Capacity } \\
\text { building }\end{array}$ & $-19,577$ & 155,873 & 0,000 & $-14,945$ & 21.6 & 0,763 & $-16,453$ & $-13,437$ \\
\hline $\begin{array}{l}\text { Networking } \\
\text { and/or } \\
\text { partnership }\end{array}$ & $-19,111$ & 156,795 & 0,000 & $-4,045$ & 27.0 & 0,211 & $-4,463$ & $-3,627$ \\
\hline
\end{tabular}


Table 23. Multiple comparisons of different certification schemes on the perceived benefits (Anova test)

\begin{tabular}{|c|c|c|c|c|c|c|c|}
\hline \multirow[b]{2}{*}{ Dependent Variable } & \multirow[b]{2}{*}{$\begin{array}{c}\text { (I) } \\
\text { Certification }\end{array}$} & \multicolumn{4}{|c|}{ Mean } & \multicolumn{2}{|c|}{$\begin{array}{c}\text { 95\% Confidence } \\
\text { Interval }\end{array}$} \\
\hline & & $\begin{array}{c}(\mathrm{J}) \\
\text { Certification }\end{array}$ & $\begin{array}{c}\text { Difference } \\
(I-J)\end{array}$ & $\begin{array}{l}\text { Std. } \\
\text { Error }\end{array}$ & Sig. & $\begin{array}{l}\text { Lower } \\
\text { Bound }\end{array}$ & $\begin{array}{l}\text { Upper } \\
\text { Bound }\end{array}$ \\
\hline \multirow[t]{4}{*}{ Economic } & $4 \mathrm{C}$ & $\mathrm{FT}$ & $4,200^{*}$ & 1,113 & 0,004 & 1,173 & 7,227 \\
\hline & & UTZ & $10,400^{*}$ & 1,329 & 0,000 & 6,756 & 14,044 \\
\hline & & RA & $4,950^{*}$ & 1,217 & 0,002 & 1,627 & 8,273 \\
\hline & FT & RA & 0,750 & 1,458 & 0,955 & $-3,169$ & 4,669 \\
\hline \multirow[t]{4}{*}{ Social/ community } & UTZ & FT & $7,000^{*}$ & 1,855 & 0,004 & 1,956 & 12,045 \\
\hline & & $4 C$ & $8,250^{*}$ & 2,028 & 0,002 & 2,712 & 13,789 \\
\hline & & RA & $17,800^{*}$ & 1,973 & 0,000 & 12,421 & 23,179 \\
\hline & FT & $4 C$ & 1,250 & 2,429 & 0,955 & $-5,282$ & 7,782 \\
\hline Representation and/or & $4 C$ & FT & $1,950^{*}$ & 0,535 & 0,005 & 0,499 & 3,400 \\
\hline \multirow[t]{3}{*}{ negotiation } & & UTZ & $2,250^{*}$ & 0,583 & 0,003 & 0,664 & 3,836 \\
\hline & & RA & $4,150^{*}$ & 0,604 & 0,000 & 2,503 & 5,797 \\
\hline & UTZ & RA & 1,900 & 0,739 & 0,065 & $-0,085$ & 3,885 \\
\hline \multirow[t]{4}{*}{ Capacity building } & RA & FT & $4,250^{*}$ & 1,436 & 0,028 & 0,365 & 8,134 \\
\hline & & $4 C$ & $5,050^{*}$ & 1,551 & 0,014 & 0,840 & 9,259 \\
\hline & & UTZ & $9,700^{*}$ & 1,913 & 0,000 & 4,458 & 14,941 \\
\hline & FT & UTZ & 5,450 & 2,115 & 0,066 & $-0,266$ & 11,165 \\
\hline & $4 \mathrm{C}$ & $\mathrm{FT}$ & $1,400^{*}$ & 0,371 & 0,004 & 0,391 & 2,409 \\
\hline \multirow{3}{*}{ and/or partnership } & & UTZ & $1,650^{*}$ & 0,406 & 0,002 & 0,542 & 2,758 \\
\hline & & RA & $3,200^{*}$ & 0,496 & 0,000 & 1,835 & 4,565 \\
\hline & $\mathrm{FT}$ & UTZ & 0,250 & 0,486 & 0,955 & $-1,056$ & 1,556 \\
\hline
\end{tabular}

Furthermore, Table 23 above and Figure 4 below show differences in perceived benefits resulting from farmers' participation in different certification schemes (Anova test). We found significant differences between the schemes, although we cannot identify clear patterns based on the schemes. In the economic domain, we see that $4 \mathrm{C}$ farmers perceive more benefits than FT and RA farmers, and considerably more benefits than the farmers participating in UTZ. In the social/ community domain, we see a reversed pattern in which UTZ farmers perceive more benefits than FT and $4 \mathrm{C}$ farmers, and considerably more than farmers participating in RA. In the third domain, representation and negotiation, participation in $4 \mathrm{C}$ again leads to the perception of higher benefits compared to FT and UTZ and even larger compared to RA. Although participation in RA is associated with a relatively low perception of benefits in the domain of representation and negotiation, it is also associated with a relatively high perception of benefits in the capacity building domain. In this domain, farmers participating in RA score significantly higher than FT and 4C farmers and considerably higher compared to farmers participating in UTZ. In the last domain, networking and/or partnership, we see that farmers participating in $4 \mathrm{C}$ perceive higher benefits than farmers who are part of FT, UTZ or RA. Overall, we conclude that participation in $4 \mathrm{C}$ seems to lead to higher benefits in 3 domains (economic, representation and negotiation, and networking), 
whereas UTZ and RA lead to higher benefits in the social community domain (UTZ) and in the domain of capacity building (RA). UTZ scores relatively low in terms of farmers' perceived benefits in the domains of economy and capacity building, whereas RA scores rather low in the social, representation, and networking domains. Although there are significant differences in benefits between Fair trade and other schemes (see Table 23), Fair trade never scores particularly well or bad in comparison to the other schemes. Based on these findings, we cannot accept hypothesis 1 (Farmers participating in the more demanding schemes (RA, UTZ, FT) perceive more benefits than farmers participating in 4 C as a less demanding scheme).

Figure 4. Differences in perceived benefits resulting from farmers' participation in different certification schemes

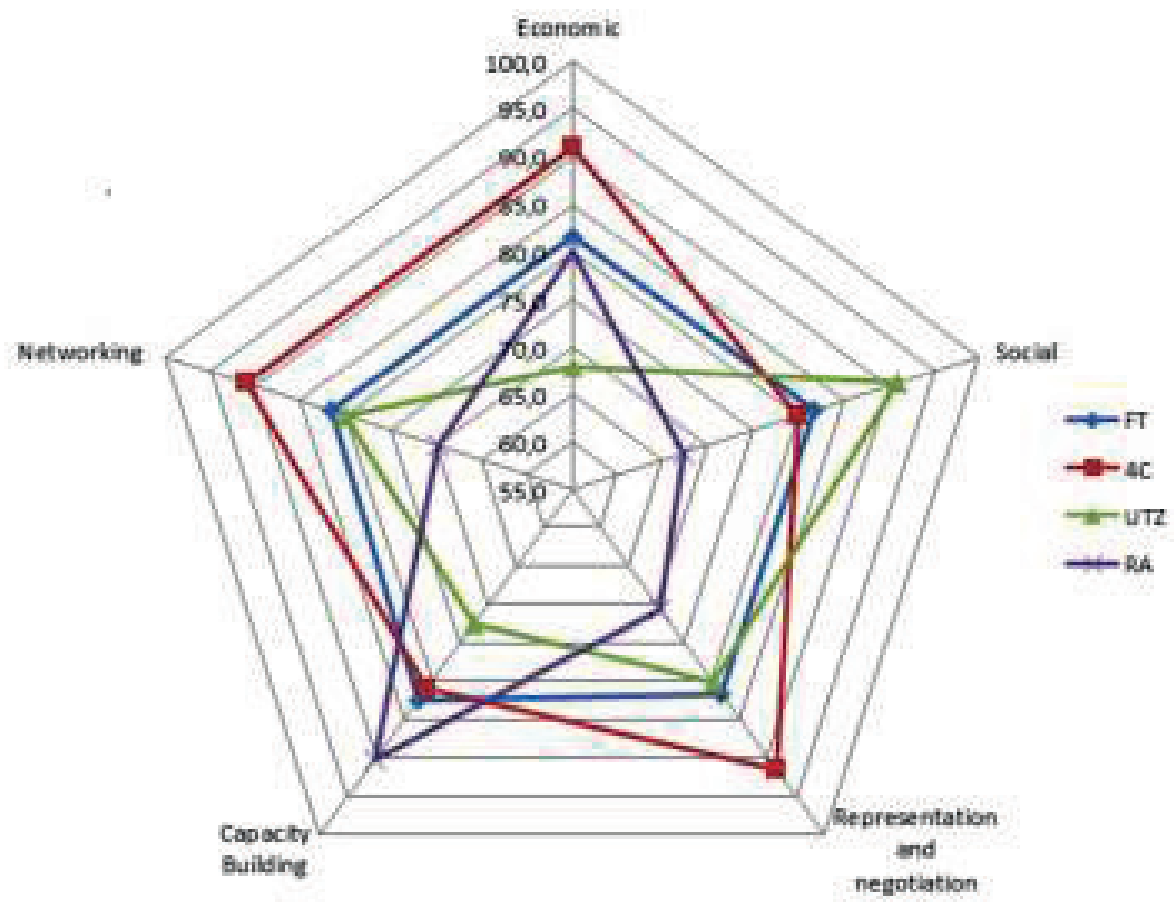

Next, we found that different types of organizational membership lead to differences in perceived benefits. Table 24 below reveals that the members of FGKUBE and FGCooperative perceive significantly higher benefits in all domains compared to farmers who are only part of a farmer group (IFG). For all benefit-domains, the differences in perceived benefits are larger between FG and FGcooperative than between FG and FGKUBE. We could however not identify any significant differences between 
FGCooperative and FGKUBE. Therefore, we reject hypothesis 2 that farmers participating in organizations with larger assets and/or capital perceive more benefits than farmers participating in organizations with fewer assets and/or capital.

Table 24. Multiple comparisons of membership of different organizations and perceived benefits (Anova test)

\begin{tabular}{|c|c|c|c|c|c|c|c|}
\hline \multirow[b]{2}{*}{ Dependent Variable } & \multicolumn{2}{|c|}{ Organization } & \multirow{2}{*}{$\begin{array}{c}\text { Mean } \\
\text { Difference } \\
(\mid-J)\end{array}$} & \multirow[b]{2}{*}{$\begin{array}{l}\text { Std. } \\
\text { Error }\end{array}$} & \multirow[b]{2}{*}{ Sig. } & \multicolumn{2}{|c|}{ 95\% Confidence Interval } \\
\hline & (।) & $(J)$ & & & & $\begin{array}{l}\text { Lower } \\
\text { Bound }\end{array}$ & $\begin{array}{l}\text { Upper } \\
\text { Bound }\end{array}$ \\
\hline \multirow[t]{3}{*}{ Economic } & FGcooperative & IFG & $4,250^{\circ}$ & 1,110 & 0,002 & 1,516 & 6,984 \\
\hline & & FGKUBE & 0,917 & 1,251 & 0,745 & $-2,112$ & 3,946 \\
\hline & FGKUBE & IFG & $3,333^{*}$ & 0,956 & 0,002 & 1,054 & 5,613 \\
\hline \multirow[t]{2}{*}{ Social/community } & FGcooperative & IFG & $7,083^{*}$ & 1,850 & 0,002 & 2,526 & 11,640 \\
\hline & FGKUBE & IFG & $5,400^{*}$ & 1,574 & 0,003 & 1,648 & 9,152 \\
\hline \multirow[t]{3}{*}{ Representation and/or negotiation } & FGcooperative & IFG & $1,817^{*}$ & 0,522 & 0,004 & 0,531 & 3,102 \\
\hline & & FGKUBE & 0,183 & 0,568 & 0,944 & $-1,197$ & 1,563 \\
\hline & FGKUBE & IFG & $1,633^{*}$ & 0,427 & 0,001 & 0,616 & 2,650 \\
\hline Capacity building & FGcooperative & IFG & $5,283^{*}$ & 1,370 & 0,002 & 1,908 & 8,658 \\
\hline & FGKUBE & IFG & $1,200^{*}$ & 0,319 & 0,001 & 0,439 & 1,961 \\
\hline
\end{tabular}

*. The mean difference is significant at the 0.05 level.

Table 25. The results of ordinal logistic regression

\begin{tabular}{|c|c|c|c|c|c|c|c|c|c|}
\hline Perceived Benefit & & Estimate & $\begin{array}{l}\text { Std. } \\
\text { Error }\end{array}$ & Wald & $\begin{array}{l}d \\
f\end{array}$ & Sig & Exp_B & Lower & Upper \\
\hline Economic & Certification & 1.199 & 0.401 & 8.957 & 1 & $0.003^{*}$ & 3.316 & 1.512 & 7.269 \\
\hline (max score 45) & Organization & 4.896 & 0.735 & 44.340 & 1 & $0.000^{*}$ & 133.707 & 31.647 & 564.900 \\
\hline $\begin{array}{l}\text { Social/ } \\
\text { community }\end{array}$ & Certification & 1.246 & 0.400 & 9.692 & 1 & $0.002^{*}$ & 3.475 & 1.586 & 7.613 \\
\hline (max score 75) & Organization & 4.618 & 0.664 & 48.317 & 1 & $0.000 *$ & 101.254 & 27.539 & 372.281 \\
\hline $\begin{array}{l}\text { Representation } \\
\text { and/or } \\
\text { negotiation }\end{array}$ & Certification & 1.367 & 0.406 & 11.367 & 1 & $0.001^{*}$ & 3.924 & 1.773 & 8.688 \\
\hline (max score 20$)$ & Organization & 5.726 & 1.092 & 27.489 & 1 & $0.000^{*}$ & 306.881 & 36.080 & 2610.175 \\
\hline Capacity & Certification & 1.567 & 0.411 & 14.538 & 1 & $0.000^{*}$ & 4.792 & 2.141 & 10.724 \\
\hline building & Organization & 5.192 & 0.827 & 39.430 & 1 & $0.000^{*}$ & 179.860 & 35.572 & 909.415 \\
\hline (max score 55$)$ & Family & 0.229 & 0.109 & 4.439 & 1 & $0.035^{*}$ & 1.257 & 1.016 & 1.555 \\
\hline $\begin{array}{l}\text { Networking } \\
\text { and/or } \\
\text { partnership }\end{array}$ & Certification & 1.341 & 0.405 & 10.994 & 1 & $0.001^{*}$ & 3.825 & 1.731 & 8.453 \\
\hline (max score 15$)$ & Organization & 5.170 & 0.828 & 38.979 & 1 & $0.000 *$ & 175.853 & 34.700 & 891.191 \\
\hline
\end{tabular}

*. Significant at $\mathrm{P}$ value $\leq 0.05$.

Table 25 above presents the results of the ordinal logistic regression. The results reveal that both certification and organization significantly influence all benefit domains. We can also see that the values of all estimates are positive, meaning that one unit increase in organization (i.e., going from $0=$ unorganized to $1=$ organized) or certification (i.e., going from $0=$ uncertified to 1 = certified) leads to higher scores on perceived benefits. Hypothesis 3 (Certified and organized farmers perceive more benefits than uncertified or unorganized farmers) can therefore be confirmed. We acknowledge that the effects of 
organization on perceived benefits mix with the effects of certification. These effects are more difficult to separate as certified farmers have dual organizational memberships whereas uncertified farmers have no or only a single organizational membership. We suggest not further analyzing and comparing the strengths of the estimates as they are counterfactually influenced by each other. The influence of certification and organization on benefits can therefore not be strictly separated.

Regarding the demographic variables, only family significantly and positively influences the perceived benefit of capacity building ( $P$ value=0.035). The value of the estimate tells us that the perceived benefit of capacity building is likely to increase by 0.229 by adding one person to a household. Although the effect can be considered relatively small, an increase in family members may enable people to share information and to learn from one another. Based on this, we conclude that capacity building processes, at least partially, may take place inside a household.

\subsection{Conclusion}

Participation in organization, as well as participation in certification, is often associated with benefits. However, both certification and organization do not represent homogeneous entities and their manifestations are diverse. In the Indonesian smallholder coffee system for example, three different organizations play a role: cooperatives, KUBEs, and farmer groups. We can also distinguish different certification schemes in the coffee sector. This paper contributes to the literature on coffee certification and organization through investigating the perceived benefits of farmers in five domains: economic, social and community, representation and negotiation, capacity building, and networking.

From our research, we observe that certification schemes seem to determine organizational structures that evolve in the coffee sector in particular regions. As observed in Aceh, FT requires the first buyers to collect coffee directly from farmers, implement floor prices, give farmers a price premium, and give payment in advance/credit if the farmers ask for it. The buyers consequently need to have sufficient financial capital and in this case, it seems that only cooperatives are feasible for doing so. The other schemes (4C, RA, and UTZ) in Lampung do not emphasize FT-like requirements, allowing KUBEs to emerge as an alternative to cooperatives in the province. Comparing Arabica and Robusta, farmers producing the former typically use a wash processing method that requires more skills than farmers cultivating the latter with a dry processing method. Indonesian Arabica is commonly produced as specialty coffee with specific attributes (tastes, origins) that further have developed a niche market with relatively loyal consumers. This differs from Indonesian Robusta that is 
typically produced with little qualitative differentiation from other Robusta coffees from other countries and subsequently markets prefer for the lowest prices. As the price of Robusta (mostly produced in Lampung) is generally lower than Arabica (typically produced in Aceh), this may further explain why incentives for stakeholders to develop cooperatives in the Robusta region are also low.

Regarding the benefits of certification, our conclusion is two-fold. First, we conclude that certified farmers perceive higher benefits than uncertified farmers in all five domains. Certification creates more market opportunities (economic and representation benefits) and provides training that improves the farmers' skills and knowledge (capacity building). Trainings mostly take place in a group, which may further strengthen the feeling of belonging to a community, contributing to a higher perception of social benefits and benefits in the domain of networking. Second, we conclude that farmers participating in different certification schemes also perceive differences in benefits. Although we cannot distinguish clear patterns based on the certification schemes the farmers participate in, we can conclude that $4 \mathrm{C}$, being known as one of the less strict schemes, scores relatively well in three benefit domains (economic, networking, and representation and negotiation). A plausible explanation is that, according to farmers and ICS staff, participation in $4 \mathrm{C}$ is less burdensome for the farmers in terms of complying with the scheme's requirements. This feeling may result in a rather positive perception in general, which also translates into a rather positive perception of benefits. It is, however, also possible that farmers who longer participate in certification (UTZ, FT, and RA) have lowered their perceived benefits compared to those who are relatively new in certification (4C).

Regarding the benefits of farmer organizations, our conclusion is also two-fold. First, we conclude that organized farmers perceive higher benefits than unorganized smallholders. The existing farmer organizations seem to perform relatively well in bringing benefits to the farmers and thus creating additional value for their members. The different types of organizations seem complimentary rather than overlapping or conflicting. FGs for example, enhance farmers' knowledge and skills regarding the technical aspects of coffee production, whereas KUBEs and cooperatives link farmers to certified coffee markets. FGs are more product-oriented, and valued as a social organization that strengthens communal relationships (among friends and neighbors). The unique value of a KUBE, which is more market-oriented, assists the FGs to comply with certification requirements and improve their management. In contrast, cooperatives work with individual farmers and assist them on individual or cluster basis. Given the value of each form of organization, the question should therefore not so much deal with a prioritization of one farmer organization over another, but rather on 
how to improve their respective strengths. Second, we conclude that organizational forms in which certified farmers participate (i.e., FGCooperatives and FGKUBEs) lead to higher perceived benefits than membership of organizational forms in which uncertified farmers participate (i.e., IFG). We can explain this through the KUBEs' and cooperatives' efforts to connect farmers to buyers (e.g., exporters or multinational companies), and through the opportunities they provide to meet and connect with farmers outside their own FGs. However, farmers participating in FGcooperatives and FGKUBEs do not significantly differ in their perceived benefits. Therefore, we conclude that these organizational differences in (financial) assets and capital have no significant influence on farmers' perceived benefits.

Indonesian coffee farmers in Lampung and Aceh generally perceive a substantive amount of benefits. We cannot distinguish large differences in benefits among the different domains; a positive feeling regarding benefit in general, seems to translate in a balanced positive feeling in all benefit domains. Empirical and objective measurement of actual benefits in the five different domains may reveal different patterns, or may reveal that the benefits in each domain differ in intensity. However, independent from the actual benefits, the farmers perceive that they benefit from certification and organization. We consider this information to be relevant in the policy domain as, in the end, it is the farmers' perception that at least partially drives the decision to participate in a sustainability scheme or organization, or to continue or terminate their membership thereof.

This paper is relevant from an academic point of view as it contributes to the debates on the impacts of sustainability standards and certification in the coffee sector. While some studies claimed that certification impacts are rather limited, our findings inform the debates that both certification and organization, from a farmer perspective, lead to perceived benefits in five domains. However, focusing on perceived benefits instead of actual benefits also implies that we have to acknowledge that different farmer communities may differ in their interpretation of reality. Perceived benefits may differ among groups, even when the farmers are confronted with the same realities. We noted, for example, that cultural differences influence the type of benefits farmers may value. In some farmer communities, wedding ceremonies, arisan and gotong royong (communal work) are considered cultural cornerstones and are valued for strengthening social relationships. In other communities however, wedding ceremonies, arisan and gotong royong are neither part of the culture nor considered to be important communal activities. Organizational support in organizing such ceremonies will therefore be differently valued by farmers in different communities. 
Further reflecting on our research model, we realize that the Indonesian context has offered challenges to our intention to strictly separate, and therefore compare, the different groups of farmers. This applies for instance to the separation between certified and uncertified farmers because many certified farmers continue their 'traditional' practices (e.g., side-selling to local traders to get direct payments in cash); certified and uncertified schemes are less easily distinguishable in practice than on paper. Further, it is also impossible to isolate the influence of organization and certification on farmers' benefits, because certified farmers are part of (dual) organizational structures whereas uncertified farmers are not organized or only participate in a single organizational membership. We acknowledge that this as a limitation of our study and, therefore, future studies should be designed to provide matching of reliable control groups to be able to distinguish the impacts or benefits resulting from participation in certification and organization. Although our sample per scheme is rather small, we are able to show some differences in perceived benefits of farmers participating in different schemes. Increasing the sample size may lead to a better understanding of farmer's perceived benefits by including coffee farmers in regions that were not covered in this study.

Finally, we want to reflect on the potential role of certification and organization in contributing to a more sustainable coffee production. Our research shows that efforts to better organize farmers may, from a farmers' benefits point of view, be equally effective as attempts to involve more farmers in certification. The implication is that improvement of farmer organizations should not only be viewed as a part of the certification process but also as a direct means to achieve a more sustainable coffee production. What could also be improved is the inclusion of farmers into organizations, particularly in remote areas where thousands of farmers are not part of any form of organization yet. In some areas, farmers have access to FGs, but participation in KUBEs or cooperatives (and therefore also in certification) remains practically impossible. Farmers in these (remote) areas therefore miss out opportunities to improve their situation in relation to the five benefit domains. Establishing farmer organizations is not an easy task, because FGs, KUBEs, and cooperatives need to be acknowledged by different ministries within the government, and a dual organizational membership is required for farmers who want to become certified. The Ministry of Agriculture can take the lead in developing FGs, but to establish KUBEs and/or cooperatives, the Ministry of Agriculture needs to collaborate with the Ministry of Social Affairs and/or the Ministry of Cooperative. Establishing new KUBEs and/or cooperatives can be done, for example, by supporting prospective members (farmers) and provide them with managerial training and assistance with collecting initial capital or investors. 



\section{Chapter}

\section{The public Indonesian standard on sustainable coffee: an exploration of its implementation capacity}

This chapter is based on:

Ibnu, M., Offermans, A., \& Glasbergen, P. (forthcoming). The public Indonesian standard on sustainable coffee: an exploration of its implementation capacity. Submitted to: Asian Journal of Agriculture and Development. 


\subsection{Introduction}

The Indonesian coffee sector is fully liberalized, which means that actors can freely operate with little state intervention. The coffee sector is open to investments from local and international businesses. Some multinational corporations invest in the Indonesian coffee sector as exporters, and some of them also as roasters. Exporters quickly adapted to the increase in demand for sustainability certified coffee in the United States (US) and Europe by participating in global private certification schemes such as Fairtrade (FT), UTZ, Rainforest Alliance (RA), and 4C. These schemes, although governing coffee production in the South, are generally initiated by Northern-based businesses and NGOs (Arifin, 2010; Bitzer et al., 2013; Bitzer \& Glasbergen, 2015). They claim to regulate agricultural production and processing methods in order to achieve better environmental and/or social conditions, to open opportunities for better access to the market, to improve farmers' livelihoods and the competitiveness of Indonesian coffee in the international market, and to alleviate poverty in rural areas (Hoffmann \& Grothaus, 2015). Many studies have tried to evaluate these claims by examining the impacts of private certification schemes on smallholders' livelihoods and welfare (see for example Carlson \& Palmer, 2016; Ibanez \& Blackman, 2016; Ruben \& Fort, 2012; Valkila, 2009; van Rijsbergen et al., 2016). However, the results of these studies are not conclusive yet and debates on the impacts of private certification are ongoing (Blackman \& Rivera, 2011; Ibnu et al., 2015; Loconto \& Dankers, 2014). In the meantime, the Indonesian government, through the Ministry of Agriculture, responded to the Northern-based private standards and private certifications by initiating a public standard and certification scheme for coffee; the so-called Indonesian Standard Coffee (ISCoffee) (Media Perkebunan, 2013).

The rise of Southern public sustainability standards and certifications can be considered a new trend. More examples can be found in Indonesia on sustainable palm oil (ISPO) and cocoa (ISCocoa). In Brazil public standards were initiated on sustainable soy ("Soja Plus") and coffee (Certifica Minas Café), in India on tea (Trustea standard for tea), and in South Africa on fruit and wine production (SIZA and WIETA). According to Schouten \& Bitzer (2015), these public standards and certifications reflect Southern actors' attempts to establish counter-initiatives to the Northern-based private standards and certifications, for which we can identify different reasons in the literature. Smith \& Fischlein (2010), for example, argue that counter-initiatives emerge because groups of stakeholders in the South feel dissatisfied with, or disadvantaged by, the outcomes of the Northern-based private standards and certifications. Wijaya \& Glasbergen (2016), however, reveal that the counter initiatives emerge because Southern governments increasingly consider the regulation of the agricultural sector to be their own responsibility. A feeling of responsibility and pride and an expression of their national 
identity also play a role for the Indonesian government in the development of national standards and certifications. In addition, Sughandi (2014) argues that, through the national standards and certifications, the government tries to expand the international market for agricultural commodities grown in their countries.

However, doubts have arisen about the international recognition of these Southern initiatives and their ability to become a viable alternative to private standards in the international market. According to Giovannucci et al. (2014), Schouten \& Bitzer (2015), and Wijaya \& Glasbergen (2016), the Southern standards and certifications may gain relevance in their domestic markets whereas Northern-based private standards and certifications will remain a prerequisite in international trade. The Southern state's authority to ensure the enforcement of the standards may also be problematic (Glasbergen \& Schouten, 2015; Hidayat et al., forthcoming). Moreover, as public southern standards are relatively recent initiatives, sometimes not even fully implemented yet, their (prospective) impacts are still unknown, particularly at the smallholder level.

ISCoffee is an example of such a standard that has not been formally implemented yet, but the Indonesian government has socialized the public initiative to stakeholders in some coffee producing regions already (e.g., Lampung and Nusa Tenggara Barat). This socialization includes pilot projects setting and verifying criteria for associations of traders, local governments, and farmer organizations (Media Perkebunan, 2013). The Indonesian government expects to fully implement ISCoffee in the near future ${ }^{21}$ and to develop it into a standard and certification scheme with significance in international trade, particularly in new emerging coffee markets in Asia and Africa that have recently overtaken Europe as the primary destination for Indonesian coffee exports (the Indonesian Ministry of Agriculture, 2015; SCP, 2014; Sughandi, 2014).

The prospective implementation of ISCoffee can be considered challenging given Indonesia's political structure with dispersed and decentralized responsibilities and given the aim to certify millions of smallholders that are geographically spread and sometimes difficult to reach. In other words, the implementation capacity of ISCoffee remains largely unknown and little attention has been given to these issues so far. This paper aims to contribute to our knowledge about the new Southern trend of public sustainability standards, answering the research questions: (1) what are barriers and

\footnotetext{
${ }^{21}$ The government has not yet determined when ISCoffee will be fully and formally implemented. The government first wants to evaluate the implementation process of ISPO (Indonesian standard palm oil) before formally implementing ISCoffee.
} 
opportunities in the implementation of ISCoffee? And (2) to what extent may ISCoffee become a viable alternative to private certification?

This paper is structured as follows: we first provide some background information on ISCoffee, its underlying principles and criteria, and differences between ISCoffee and Northern-based private standards and certifications. We then present our analytical framework (section 4) to analyze the implementation capacity of ISCoffee. After that, we present our findings in section 5. In the final section (section 6), our conclusion, reflection, and recommendations regarding the implementation capacity of ISCoffee can be found.

\subsection{Indonesian Standard Coffee (ISCoffee): the main principles and criteria}

The government had established the compulsory National Standard of Indonesia or Standar Nasional Indonesia (SNI) ${ }^{22}$ in 2000 already. However, SNI only covers the quality of coffee beans and processed coffee (e.g., instant coffee, roasted coffee). ISCoffee can therefore be considered the first attempt of the government to more comprehensively pay attention to the sustainability of the coffee production process. There is, however, a relationship between SNI and ISCoffee. According to the government, the coffee sector must follow government regulations, including the aspects of legality and SNI-based criteria embedded in ISCoffee principles and criteria. ISCoffee formulates baseline sustainability principles and criteria with the aim to provide a base-level of standards at low costs for Indonesian farmers (Ditjenbun, 2013). By using local auditors and national, governmentally accredited certification agencies, ISCoffee is projected to be less costly for farmer organizations than Northern-based private standards. In this way, farmer organizations can more easily afford certification, which theoretically may increase their bargaining power towards buyers (Media Perkebunan, 2013). ISCoffee is inspired by, and therefore rather similar to Northern-based private standards and certifications. Both contain principles, decomposed in criteria, which cover economic, social, and environmental issues. Although ISCoffee's standards are inspired by standards from private certification schemes, the criteria and underlying regulations are not directly derived from the private standards, but collected from already existing regulations from different Indonesian ministries. Table 26 below reveals the 5 principles and 23 criteria that are part of ISCoffee.

\footnotetext{
${ }^{22} \mathrm{SNI}$ is a national standard set by the Indonesian National Standardization Agency, specifying the classification, the labelling and the packaging of coffee green beans (PP RI No. 102, 2000).
} 
Table 26. Principles and criteria underlying ISCoffee

\begin{tabular}{l}
\hline Principles and criteria \\
\hline $1 . \quad$ Legality \\
$>\quad$ Legality of farmers' land \\
$\quad \begin{array}{l}\text { Location of plantation is } \\
\text { appropriate } \\
\text { Individual farmers must join } \\
\text { farmer groups }\end{array}$
\end{tabular}

\section{Farming, harvest, and post-harvest}

$>$ Plantation opening fulfil the principles of water conservation

$>$ Seeds must be from breeders that are recommended by the government

$>$ Farmers grow shade trees

Cultivation are done with the technique and/or method suggested by ISCoffee's indicators

$>$ Farmers do intercropping before coffee tress grows and produce cherries.

$>$ Harvest with the technique and/or method suggested by ISCoffee's criteria

$>$ Farmers sort the cherries according to their quality (size, maturity, and defects)

Farmers remove the cherries' flesh and skin with dry or wet processing method

After drying, farmers (re)sort coffee beans according to size and defect

Farmers sell their complete coffee production to

cooperatives/companies based on an agreement on minimum prices
Indicators*

Realization

- Land certificate, or document of landlease agreement

Year 1

Year 2

- Letter of permission to cultivate coffee

Year 3 Geospatial Information Board (Badan informasi geospatial)

- Document of farmer group establishment; document of operational planning; document of group activities

- $\quad$ Farmers' records of this activity

Year 1

- $\quad$ Seed are from breeders that have been

Year 1 certified by certification bodies accredited by the government

- $\quad$ Farmers have records on the shade trees planted

- Farmers' records of their cultivation Year 1 activity

- Farmers' records of this activity

Year 1

- $\quad$ Farmers' records of the harvesting activity

- $\quad$ Farmers' records of their sorting activity

- $\quad$ Farmers follows the processing guideline of ISCoffee; Farmers record these activities

- $\quad$ Farmers record the sorting activities; The defect value is based on the national standard of SNI 01-2907-208

- Document of the selling agreement between farmer groups and cooperatives /companies; the availability of a document that explains the pricesetting mechanism; records of selling activities (including quantity and coffee prices)
Year 1

Year 1

Year 1

Year 3

Year 2 
3. Farmer organizations and working conditions

$>$ Establishment cooperatives

- $\quad$ Farmer groups join to form cooperatives, and local

Year 2 governments facilitate the establishment of cooperatives

$>$ Joining Coffee farmer's Farmers join the Indonesian coffee farmer associations association (Asosiasi petani kopi Indonesia/APEKI) at provincial level

Farmers prioritize health and safety conditions of workers

- $\quad$ Farmers provide safety equipment for themselves or workers; farmers do not employ under-aged children (not employees in general) for doing high risk jobs such as applying pesticides, and pruning coffee trees.

$>$ Farmer organizations improve the capacity building of members (farmers)

- Farmer groups establish profitable business, and they identify the needs for training required

Year 3

Year 1

Year 2

4. Social aspects commitment to improve local potential

$>$ Farmers participate in improving public facilities

$>$ Appreciation of local wisdom and local culture

\section{Environmental aspects}

$>$ Farmers manage waste

- $\quad$ Farmers follow ISCoffee indicator

Year 1

$>$ Farmers must prevent and extinguish fire around plantations.

$>$ Farmers improve biodiversity Farmers record the activities that realize the commitment

- $\quad$ Farmers involve in activities to improve facilities in rural areas (by communal work or gotong royong)

- Farmers make an agreement to list local wisdom/culture that needs to be preserved and make schedule of activities to preserve local wisdom/culture

Year 2

Year 2

Year 1

- $\quad$ Farmers follow the guidance from ISCoffee to deal with fire.

- $\quad$ Farmers recognize and then make a list of protected

Year 1 flora and fauna in their regions

$>$ Farmers protect water sources

- $\quad$ Farmers do not open coffee plantations near water sources

- $\quad$ Farmers protect river banks by planting trees along the banks.

Year 2

Farmers improve soil fertility

- $\quad$ Farmers use fertilizers recommended by relevant agencies that have been approved by the government; farmers increase the use of organic fertilizers and reduce the chemical fertilizers

Farmers make buffer Buffer zones are area between coffee plantations zones and their neighboring environments. The area must be planted with perennial plants that conserve soils and enhance biodiversity.

\footnotetext{
* Not all of 85 indicators are presented
}

Source: ISCoffee draft (The Directorate General of Estate Crops of Indonesia, 2013)

Coffee producers need to gradually (i.e. within three years), after the formal initiation of ISCoffee, comply with all principles and criteria. In the first year, for example, farmers are expected to obtain a land-ownership or lease agreement certificate, and they need 
to make buffer zones between their coffee plantations and neighbouring environments. In the second year, farmers must have a list of protected flora and fauna in their region, and in the third year, farmers must record all activities, from planting, harvesting, and processing, to sorting and selling. All farmers in farmer organizations are expected to fulfill the requirements collectively. Information on the principles and criteria may come from the government or extension officers, transferred to farmers through farmer organizations. Local governments, in collaboration with trader associations, and the National government, are expected to facilitate the establishment of provincial APEKIs (the Indonesian coffee farmer association). Until now, ISCofee has not yet been launched yet and therefore there is no explicit information about, for example, the certification agencies used by ISCoffee and what happens if farmers do not comply with all criteria within three years. However, ISCoffee might use a rather similar step as 4C, another baseline scheme, with corrective measures within a given timeframe in cases of non-compliance (GCP, 2017).

If we compare the principles and criteria in 31 with principles and criteria underlying the private certification schemes, we, firstly, see that ISCoffee Table identifies fewer principles. 4C, for example, has twice as many principles (10) compared to ISCoffee $(5)^{23}$. Schemes with high (e.g., FT and RA) and medium (e.g., UTZ) levels of stringency focus on specific sustainability dimensions (Reinecke et al., 2012), and they have more principles and criteria than $4 \mathrm{C}$ and ISCoffee. FT and UTZ contain more than 50 core principles whereas RA has 37 core criteria out of 119 criteria total for crop farms (FT, 2014; RA, 2017; UTZ, 2015). ISCoffee is also less stringent than private certification schemes (FT, UTZ, RA). For example, although both ISCoffee and private schemes in general forbid child labour, the former are still allowed children to work in coffee plantation (e.g., to help their parents picking cherries, bring foods etc.) as long as the children are not involved in high-risk activities (e.g., applying pesticides, pruning coffee trees etc.).

Content-wise, we can also identify differences between private coffee standards and ISCoffee. A first difference is the emphasis ISCoffee puts on issues related to legality. To become ISCoffee certified, farmers have to be able to show a land-ownership certificate or a land-lease agreement, and they need to prove that their plantations are not located in protected forests through obtaining a clarification letter from the relevant government agency (Media Perkebunan, 2013). Private schemes do not require farmers to proof their legal status, but plantations in conflict with local communities and located in protected forests cannot be certified under private schemes.

${ }^{23}$ Based on 4C baseline common code ve.2.1 (GCP, 2017). 
Second, ISCoffee includes principles related to technical aspects of coffee production that farmers have to adapt such as growing coffee with shade trees and intercropping and shorting coffee cherries based on their sizes and maturities (i.e., Permentan RI No. 52 , 2012). More detailed, through this principle, the government wants to ensure that farmers only use coffee seeds that are certified by governmentally recommended agencies to improve productivity and to protect farmers from using low quality seed sold by unregistered nurseries (Permentan RI No. 89, 2013). Private schemes, on the other hand, suggest farmers to use good seeds that are resistant to pests, diseases and droughts, and inputs that are adapted to local ecological and agronomical conditions. The schemes list and update available seed providers but, if suitable varieties or local provider are not available, on-site nurseries are set up.

Third, similar to Northern-based private standards and certifications, IScoffee does not certify individual farmers, but groups of farmers. While private schemes do not have further requirements on the legal status or composition of these groups which are allowed to be an informal collection of individual farmers (Loconto \& Dankers, 2014), ISCoffee explicitly requires farmers to be formally organized in farmer groups, KUBEs or cooperatives $^{24}$. In some cases, this implies that these organizations first need to be established, and that KUBEs may have to become replaced by cooperatives.

In Indonesia, 1.96 million farmer households (i.e., more than five million individuals) depend on coffee production as their main source of income (BPS-statistics Indonesia, 2013; the Directorate General of Estate Crops, 2015). The national government resides in Jakarta and consists of different ministries, including the Ministry of Agriculture. This ministry subsequently exists of several directorates, including the Directorate General of Estate Crops that creates policies for the coffee sector. The directorate has local, decentralized units called dinas perkebunan (disbun) that exist at the provincial level (i.e., disbun provinsi) and district level (i.e., disbun kabupaten). Indonesia's political structure is highly decentralized and local governments (divided in four legislative echelons) are led by a gubernur on the provincial level, a bupati on the district level, a camat on the sub-district level, and a kepala desa on the village level. ISCoffee was initiated by the Directorate General of Estate Crops and can therefore be considered a national program that will be implemented in, and delegated to, the local units. The bureaucratic lines start from the directorate to the disbun provinsi and then to the disbun kabupaten. The law on regional autonomy further implies that those disbuns are

\footnotetext{
${ }^{24}$ Three types of farmer organizations play a role in the coffee sector: farmer groups, cooperatives and KUBEs. They have different organizational characteristics because they were initiated and are managed by different ministries with different sets of rules (see chapter).
} 
formally obliged to cooperate with, and ask support from, the local governments in the implementation process of ISCoffee.

\subsection{Analytical framework}

In this paper, we define implementation capacity as the ability of stakeholders (e.g., farmers, actors on different governmental levels, businesses etc.) to design and to put into practice a specified set of activities in order to perform functions and achieve (longlasting) objectives (Bitzer, 2011; Curry, 2000; Ellis et al., 2006). Based on literature in the fields of public administration, business management, organizational management, and innovation studies, we define five essential building blocks through which implementation capacity can be analyzed (see Figure 5 below). First, the presence of a univocal regulatory framework, which refers to explicit, formalized policies and rules on different governmental levels that do not conflict with already existing regulations (Dieperink et al., 2004; Smit et al., 2011; Vermeulen \& Hovens, 2006). Second, resources, knowledge and expertise, which denote the availability of assets, infrastructures, facilities, and competent personnel with knowledge and expertise on technical aspects (e.g., tools, diseases, pests, soils, seeds) and managerial/non-technical aspects (e.g., communication and organization (Devas, 1997; Guijarro, 2007; Stapel \& Schneider, 2012). The rules should thus be clear for ISCoffee personnel and they should be able to communicate this information in a proper way to companies and smallholders. Third, the quality of the public administration, which refers to the extent to which the public administration can be trusted, considered legitimate and free of corruption. Relevant indicators include the transparency of processes and administrative procedures, and accessible public institutions that serve the community (Comfort, 2007; Gray \& Jenkins, 1995; Kelly, 2005; Löffler, 2001; Porter, 2000). Fourth, the economic context (market), which refers to the extent to which market conditions (both domestically and internationally) can enable or constrain actors to adopt the standards (Trienekens, 2011; Vermeulen \& Hovens, 2006; Wijaya \& Glasbergen, 2016). Without any demand for standards in the market, incentives to comply with principles and criteria may be non-existent. Fifth, the political context, which refers to political agendas (including the priority given to ISCoffee) that drive government officials at different administrative levels to develop and further implement ISCoffee (Agterbosch et al., 2009; Patterson et al., 2016; Thow et al., 2015). It also covers the quality of the political collaboration across the different administrative levels. 
Figure 5. Building blocks to analyze the implementation capacity of ISCoffee

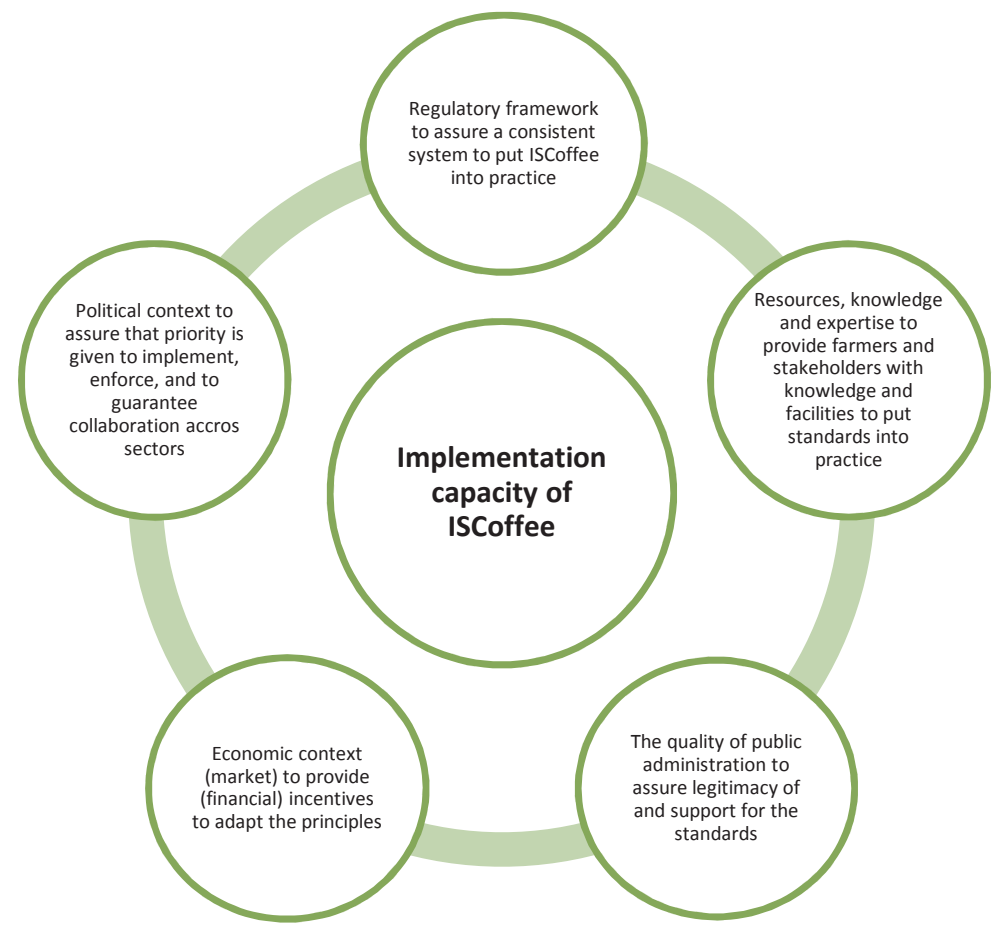

\subsection{Methods}

The main research methods employed in this study are in-depth interviews and document analysis. Data collection took place between November 2016 and January 2017. The interview questions related to the five building blocks addressed enabling or constraining for the implementation of activities under ISCoffee. We interviewed actors at the national level, including experts, and heads of departments or divisions within the Ministry of Agriculture (i.e., the Directorate General of Estate Crops), the Ministry of Trade (i.e., the Department of Domestic and Export trading) and the Ministry of Industry (i.e., the Department of Food and Beverages). Furthermore, we interviewed local government officers at provincial and district levels in Lampung, including representatives from the department of estate crops, the department of trade, and the governmental extension office. As the province of Lampung is the main coffee producing region in Indonesia, and ISCoffee has been socialized to stakeholders in this region, the interviews at the local level were conducted with actors from this province (i.e., Tanggamus and the West Lampung District). Next to interviewing government officials, we also included informants from exporters and actors from AICE (the association of Indonesian coffee exporters), farmer organizations, universities, NGOs, 
and village leaders. In total, we conducted 30 interviews (see Table 27 below). We stopped with the selection of interviewees when we did not receive any new information and had the feeling that we understood the implementation.

Table 27. List of informants

Categories Number of informants

\begin{tabular}{lr}
\hline A. Interviews -2016 & 2 \\
NGOs & 6 \\
National government officials & 5 \\
Local government officials & 4 \\
Researchers (from university and research institute) & 2 \\
Village leaders & 3 \\
Exporter and association of Indonesian coffee exporter (AICE) & 8 \\
Farmer organizations & 30 \\
Total interviews &
\end{tabular}

B. Printed and online documents

Unpublished document of government body* 2

Published document of government body** 1

Unpublished document of AICE*** 2

Online Media 3

Magazines 2

Material presentations from roundtable workshop (February $4^{\text {th }}$ ) 3

Total Documents

* including an unpublished report of the local government on ISCoffee field testing, and the draft of ISCoffee principles and criteria

**including a strategic plan of the Directorate General of Estate Crops

$* * *$ report and letter

We recorded and summarized the interviews and then clustered the information in the corresponding building blocks and operationalized variables (i.e., sub building blocks as mentioned in section 3). In addition to the interviews, we analyzed a variety of written materials (printed and online), including scientific articles, published and unpublished documents from governmental and non-governmental institutions, news-articles from Indonesian media (e.g., Ditjenbun, Perkenbunannews, and Sinar Tani), and magazines such as 'Media Perkebunan' and 'Agro-Industri' that present the Indonesian government's policies and programs regarding coffee. In addition, we also used presentation materials from a roundtable workshop held on February 42014 and organized by the Indonesian Ministry of Trade and the Word Bank to discuss opportunities, barriers, and development strategies for Indonesian coffee. This meeting comprised speeches and presentations on topics related to sustainability standards and certifications. 


\subsection{Results}

\section{Regulatory framework}

In general, respondents expressed their concern on the lack of clear regulations for the implementation of ISCoffee. Although ISCoffee seems to aim for one consistent form of regulation on the highest political level, most respondents expressed doubts on the feasibility of this aim. Part of this doubt seems to come from the fact that the government currently heavily focusses on the implementation and evaluation of the public standard on palm oil (ISPO). Turbulent experiences with ISPO further contributed to a rather passive attitude of the government regarding ISCoffee in general and postponement of the formulation of explicit policies and rules in particular on all administrative levels. A respondent from the Directorate General of Estate Crops stated:

For ISCoffee, the directorate prefers to develop regulations on a higher administrative level than the ministerial level (i.e., a presidential regulation), but until now, such a regulation has not yet been determined because the government still focuses on ISPO.

We also found that existing regulations may conflict with, and therefore hamper, the implementation of ISCoffee. The regulation on HKM (hutan kawasan masyarakat) community-based forestry management) was mentioned by the respondents as an example. The current HKM law allows farmers to cultivate coffee in protected forests under the prerequisite that they have permission from the government (i.e., a five-year extendable contract) (Arifin et al., 2009). But, according to the sustainability principles and criteria they are not eligible to participate in sustainability standards and certifications, including ISCoffee. This conflict may also threaten ISCoffee's objective to certify all coffee smallholders in Indonesia. However, the development of ISCoffee can also be viewed in a positive way. Before ISCoffee, it was rather difficult to understand the meaning of the numerous regulations in the coffee sector. ISCoffee may harmonize these regulations and may lead to a more univocal regulation on coffee.

\section{Resources, knowledge and expertise}

Currently, institutions that specialize in coffee research ${ }^{25}$ provide support to farmers in the form of coffee production techniques and the delivery of good quality seeds. Indonesia also has a public extension system that provides farmers with up-to-date information. These research institutes and the extension system may provide

\footnotetext{
${ }^{25}$ Either managed by the Directorate General of Plantation (i.e., as one of its operational units) or as an independent organization (i.e., the Indonesian Coffee and Cocoa Research Institute).
} 
opportunities for ISCoffee to communicate their rules and standards to the farmers via already existing and institutionalized networks and infrastructures. However, the extension system is heavily criticized for being inefficient and prioritizing rice production (Agustian \& Rachman, 2015). In Indonesia, perennial cash crops (e.g., coffee, cocoa, coconut and oil palm), and staple foods (e.g., rice, maize, and soybean) are considered belonging to separate sectors (the Directorate General of Estate Crops, 2015). Both sectors are governed by the Ministry of Agriculture that, however, seems to prioritize staple foods over cash crops. The extension agency, as a unit of the Ministry of Agriculture, is subsequently mandated to focus more on staple foods than on coffee. Extension officers work by visiting farmer groups to convey information and share knowledge and this will be challenging as coffee farmers live in rural, often remote areas that are difficult to access and have poor infrastructural conditions. Extension officers are therefore often criticized for not having enough knowledge on the technical aspects and challenges of coffee production. As an extension officer stated:

I think it rarely happens that extension officers specialize in coffee. Extension officers mostly have knowledge and expertise about the production of rice, maize, and other staple foods. [The prioritization of maize and rice over cash crops can be explained because] without staple foods people will become hungry and angry. coffee scarcity may not have these effects.

Other institutions (e.g., NGOs, research institutes, universities, and businesses) could potentially contribute to improving farmers' knowledge and communicate ISCoffee. Linkages between research institutes and universities and the coffee sector are, however, often based on personal connections (between individual researchers and farmers) rather than institutional-based commitments. This implies that institutional mechanisms to link knowledge and expertise providers to farmers are rather weak and subsequently the contributions of these organizations may not be optimal. Given the ineffectiveness or non-existence of structural knowledge exchange networks beyond government's channels, ISCoffee will considerably depend on the capacity of the government to handle the process of providing knowledge/information and communication to the millions of coffee farmers and auditors. Such a process needs to involve government staff across departments and levels. The problem, however, is that government staff, particularly at local levels, is often criticized for its limited knowledge and expertise on the implementation of strategic programs due to limited opportunities to develop their capacities. 
Chapter 5

A representative of dinas kabupaten stated:

Many governmental employees have inadequate knowledge and expertise regarding implementation of programs. They are often included in ad hoc teams for a relatively short period and therefore lack the time to improve their knowledge and expertise on management issues.

In Indonesia, there is an abundant amount of government employees (the Ministry of Home Affairs, 2016). This implies that, theoretically, the government has sufficient staff to run its programs across the country. The staff is, however, not proportionally distributed across different government agencies at different levels. We also observed that government employees are burdened with various tasks related to other agricultural commodities and spend most of their time on reporting. The implication is that government staff tends to develop administrative skills more than managerial skills required to run a program like ISCoffee. Moreover, ISCoffee's requirement that farmers solely use coffee seeds produced by credible and accredited seed centres, offers challenges in terms of infrastructural facilities. Because of budget constraints, necessary infrastructures for the distribution of certified coffee seeds may not materialize, especially in remote regions. The risk is then that famers in remote areas keep using uncertified seeds. As a representative of the Directorate General of Estate Crops stated:

Budget constraints are a clear challenge for running governmental programs. Only five percent of the state budget is allocated to the plantation unit [the unit responsible for all cash crops], which is insufficient to build the required supporting infrastructures, including seed infrastructures. Credible infrastructures such as seed centers are currently limited in number, which may not guarantee the availability of certified seed in disperse locations.

Many national programs have been implemented in the plantation sector prior to ISCoffee, and among their legacies in the coffee sector are farmer organizations. ISCoffee may benefit from the existing farmer organizations and use them as media for information, communication and knowledge transfer at the farmer level. At the rural level, village leaders may provide potential support for ISCoffee's information flow and communication; and information technology may further speed up the distribution of information regarding the public standard to all stakeholders. Many farmers are, however, still unorganized and this further challenges the provision of information to all farmers in disperse location. We foresee that this will become a problem in the communication and knowledge-supply between ISCoffee and farmers. 


\section{Quality of the public administration}

Reformation aimed to establish good governance that is free of corruption, collusion, and nepotism (Anggraini, 2014). This is an opportunity for ISCoffee as corruption, for example, to some extent, has been controlled by $\mathrm{KPK}^{26}$ (Anggraini, 2014; Sudibyo, 2012). However, we found that other issues related to the public administration may pose a threat to ISCoffee's legitimacy, including the existence of administrative problems, and farmers' low trust and feelings of unfair treatment by the government. The governments' transparency in decision making procedures is also considered to be relatively low. Regarding transparency and fairness farmers perceive choices of the government made in the past to be highly subjective and selective. An example can be found in the governmental financing scheme of PUAP or Pengembangan Usaha Agribisnis Pedesaan intended to help farmers improving their agricultural production and agribusinesses (Indraningsih et al., 2015). A farmer respondent stated:

My farmer group was not involved in PUAP, but other farmer groups were. I don't know how the other groups could be involved in the program. I think the selection method (done by village leaders) was very subjective.

Furthermore, farmers seem hesitant to deal with the public administration because they perceive administrative procedures as difficult and the attitude of public administrations' staff as not supportive. As a farmer respondent stated:

I believe that the majority of farmers has lands without certificate from the government. They only have a proof of ownership acknowledged by their village leaders and elderly people. I think farmers are now hesitant to get their land certified because of the perceived difficulty of administrative procedures and 'extra' costs. I once tried to get an explanation about the costs, but I received unfriendly responses.

As ISCoffee requires farmers to certify their land, farmers' hesitancy to start procedures to get their lands certified may slow down and challenge the implementation capacity of the public standard. Moreover, an unpublished report of dinas provinsi on the fieldtesting of ISCoffee reveals that most difficulties perceived by farmers relate to administrative requirements. The interviews with farmer groups indeed revealed that the administrative requirements that come along with ISCoffee will be burdensome for them, which may further lead to reluctance to fulfilling the requirements.

\footnotetext{
${ }^{26}$ KPK (Komisi Pemberantasan Korupsi) is an independent state institution that works to eradicate corruptions in the government bodies (UU RI No. 30, 2002).
} 
As a leader of a farmer group stated:

I think we (farmers) do not have problems with (any) technical requirements for improving coffee production. Most of us love to learn to produce better coffee. Administrative requirements, however, will be very challenging for farmer groups, they are complex and confusing.

Another issue regards the acceptance of iCoffee by locally-based market players. To date, the local market players have little connections with sustainability standards and certification. Even though the local players adopt the practices and the standards, it may only be at the 'surface', and it can further be doubted whether ISCoffee can realize their 'truly' compliance with the standard principles.

\section{Economic context (market)}

The demand for coffee in international markets influences the Indonesian coffee sector, as the market defines the required coffee quality and prices. Quality requirements may also touch upon the way in which the coffee is produced (i.e., in a sustainable way). According to Sughandi (2014), Indonesia exports around 56\% of the total coffee production to new markets in Asia and Africa. At the same time, the demand for Indonesian coffee from the domestic market is increasing by more than five percent per year (Agro-Industri, 2016; SCP, 2014; Sughandi, 2014). For farmers, this diversification of market opportunities can be beneficial as demands from markets for their coffee are increasing.

Although the diversification of markets seems to be promising, we can also identify potential barriers in the market domain to the implementation of ISCoffee. The first barrier relates to difficulties to convince traders (i.e., nationally-based and internationally-based companies) to adopt and follow the ISCoffee standard. Nationalbased companies collect (uncertified) coffee beans from smaller local collectors (middlemen) and trade them to domestic and (upcoming) international markets. If ISCoffee is implemented, these local companies must buy coffee from farmers certified with the public standard. This implies that these companies have to strengthen their connection with farmers and assist them in complying with the standards, which can be considered challenging as they have very limited direct contacts with farmers, but mostly with middlemen. These companies have little experience in implementing sustainability standards and certification. This is a potential barrier to ISCoffee implementation as the nationally-based companies may not be easily convinced to change their practices, and to make new investments, such as creating a specialized 
department dedicated to sustainable coffee production and recruiting competent people for the department. As a representative of AICE stated:

Most national companies have little experience with certification guidelines. These companies need significant changes in their operations to implement ISCoffee, including the establishment of a sustainability division. This division needs to work with farmers, helping them to fulfil certification requirements. This can be problematic for these companies because they do not have stable connections with farmers. They collect coffee beans from local traders or collectors in various areas.

Sustainability certified coffee is not considered important in the domestic market as relatively few consumers are aware of sustainability standards. The new emerging markets (e.g., China, India, Egypt, and Morocco) also do not prioritize certified coffee (Wijaya \& Glasbergen, 2016). Thus, these markets are not a strong driver for the national companies to adopt sustainability practices and ISCoffee.

Compared to the national-based companies, internationally-based businesses have more experiences in implementing sustainability standards and certification. An internationally-based company usually has partners in other coffee producing countries. Multinationals supply coffee predominantly to the Northern markets in which buyers prioritize private sustainability standards and certification. The multinationals that operate in Indonesia, at some point, have to decide on the adoption of ISCoffee as a credible and alternative standard for the Northern-based private standards and certifications. From the perspective of a multinational company, this will be a rather challenging decision because ISCoffee may not be perceived a credible standard in the Northern markets. The decision may further be complicated by the fact that a multinational company's decision also relates to partners in other countries, as a representative of a multinational trader/exporter stated:

The company's policies are not fully independent, but relate to partners in other countries. It is unlikely that the company's partners adopt ISCoffee in their operation in Vietnam or in other countries because they may have other priorities and/or preferences. Our company may not be able to adopt ISCoffee and push the partners to adopt it. 


\section{Political context}

The Directorate General of Estate Crops that initiated ISCoffee feels that other directorates do not fully commit to assisting ISCoffee's implementation. As a government officer from the Directorate General of Estate Crops stated:

We feel that we get less support from others [other directorates]. We struggle alone for ISPO, ISCOCOa, and now for ISCoffee. The others seem to consider that these standards are only the responsibility of our directorate.

Responsibility here does not refer to authority or enforcement but refers to a sense of ownership to ISCoffee. It seems that government agencies outside the Ministry of Agriculture think that ISCoffee is not their program and subsequently they do not take responsibility for developing it. In other words, their sense of ownership is low, and this affects the effectiveness of collaboration among government agencies, which may further hamper ISCoffee implementation. At the local level, village leaders may also have agendas or priorities that are not in line with ISCoffee. Their support for trainings and knowledge exchange under the umbrella of ISCoffee can therefore be questioned and not be taken for granted.

Regarding village leaders, one former village leader stated:

To be honest, a village leader is more a political position than a governmental agent. Village leaders may not effectively communicate ISCoffee to farmers. They have their own agendas in the villages.

In the era of regional autonomy, the allocation of power and responsibilities between the national and local government is still rather ineffective. On the one hand, the national government seems to lose some control over local governments because the latter have significant power to govern their respective regions (Devas, 1997). On the other hand, local governments often show an inactive attitude toward national policies and/or mandates because they prefer to implement their own local-made regulations. These issues will likely increase difficulties as regards the implementation of ISCoffee. One example can be found in the case of geographical indication (GI). The GI is established by the national government to formally assure that certain agricultural commodities originate from particular regions and local governments are mandated to actively play a role in supporting its implementation. The Gl certificate is held not by local governments, but by Masyarakat Perlindungan Indikasi Geografis or Geographical Indication Protection Society (Wahyudi \& Jati, 2012). Not all local governments, however, intend to actively participate in GI. It seems that the national agenda to 
implement $\mathrm{Gl}$ has not been integrated very well in the local priorities. A respondent from AICE stated:

In this province, the local government is not active in Gl. I found that no noticeable activities or significant outputs are realized by the government related to the certification.

The respondent further implicitly expressed a doubt whether the national government can enforce ISCoffee easily at local levels because local governments have significant political authority and (specific) home rules in their respective regions (because of regional autonomy). Furthermore, the government institutions feel a different sense of urgency about sectors and commodities, which results in different views, for example, on the importance of coffee vis-à-vis other agricultural commodities. This sense of urgency may further explain why some ministerial directorates are rather uninterested in coffee and/or ISCoffee. A government officer from the Directorate General of Trade illustrated this:

The main concern of our department is trade. We support the marketing of all agricultural commodities, but the most important ones are rice, maize, and other staple foods. Compared to these staple foods, we do not interfere too much in coffee.

\subsection{Conclusions}

This paper contributes to the literature on sustainability standards and certifications with an analysis of the implementation capacity of ISCoffee as a Southern-based public standard and certification scheme initiated by the Indonesian government. This paper analyzes the opportunities and barriers in the process of implementing ISCoffee and whether the public standard can become a viable alternative to Northern-based private standards and certification.

Our analysis, which is based on building blocks, reveals that some opportunities are available for ISCoffee implementation. These include reduced corruption at bureaucratic levels, the availability of a public extension system and institutions that specialize in coffee, and the availability of channels and media for information-flow, communication and knowledge transfer. We foresee, however, that barriers for ISCoffee implementation will likely weaken these opportunities. The barriers include the government's passive attitude to formulate explicit policies and rules in particular and on all administrative levels, and government personnel's limited knowledge and expertise on the implementation of strategic programs. These barriers are exacerbated 
by an inefficient extension system, limited infrastructures and weak farmer organizations. Because of administrative problems and coordination deficiencies, ISCoffee will also be vulnerable to legitimacy problems indicated by limited potential supports from farmers, from markets players, and from different government agencies at different levels. All of these barriers lead us to arrive at the first conclusion that ISCoffee is likely to have a limited implementation capacity in the Indonesian coffee sector.

We reflect that ISCoffee seems to be a collection of existing regulations with the intention to use existing implementation channels. These channels (including infrastructures, networks to distribute seeds, and networks to provide information) have demonstrated not to be able to significantly improve the position of the smallholder. The question therefore is whether ISCoffee will be able to improve the farmers' situation as long as it remains using existing channels without significantly altering them. The current functioning of these channels, exacerbated by ISCoffee's limited implementation capacity, allow us to formulate our second conclusion that ISCoffee - in the short term - will not become a viable alternative to Northern-based private standards and certifications.

Based on specific weaknesses linked to each building block, we argue that there are six recommendations that can be considered to improve ISCoffee. First, regulation on ISCoffee and relevant administrative levels should be coherently established and, at the same time, potential conflicts with existing regulations should be addressed. For these, relevant ministries, including the Ministry of Agriculture, the Ministry of Home Affairs, and the Ministry of Rural and Underdeveloped Regions, and The Ministry of Environment and Forestry should collaborate. Mediated by the Ministry of National Development Planning, the ministries should first address any barriers for effective collaboration. After that, a regulation and/or a standard operating procedure (SOP) should be established to guide them and their subordinate levels to effectively cooperate. Second, ISCoffee should be better placed in the bureaucracy, managed by a national-level secretariat and human resources with relevant expertise. The sustainability secretariat needs to have a (strong) position in the bureaucracy and the power to enforce ISCoffee implementation at both national and local levels. Third, the quality of public administration needs to be improved by addressing the issues of administrative structures, transparency, and coordination deficiencies. One of the plausible ways is involving relevant government institutions that are either directly or indirectly related to ISCoffee. For example, to help farmers with procedures and/or administrative requirements and costs associated with land certification, the Ministry of Agriculture should take the lead to collaborate with the Ministry of Agrarian and Spatial Planning/National Land Agency. Fourth, infrastructures in the coffee production system 
and in rural areas should be improved through enhanced investments, by involving relevant ministries collaborating with local governments. The collaborations should be clear and manifested in formal agreements with commitments regarding responsibilities and resources that will be shared. Fifth, we endorse an enhanced collaboration between the government and market players to promote sustainability certified coffee in the Southern markets and to further induce the demands from the market. In this way, an enabling environment (market) may become supportive for ISCoffee. Sixth, the government should be proactive to consistently socialize ISCoffee to the coffee sectors' stakeholders, especially smallholders, to improve their understanding of the standard and to further integrate it in their farming practices.

Furthermore, we observed some problems in the Indonesian coffee sector. First, problems regarding the procurement of farming inputs. Currently inputs are underutilized because farmers cannot afford them and because infrastructures (i.e., delivery systems) do not perform as expected (de wolf, 2013; the Directorate General of Estate Crops, 2015). Productivity subsequently remains low, and the rush and time pressure in peak seasons, the use of outdated processing machinery, and low knowledge and skills further contribute to the low quality of coffee beans produced by smallholders. Second, problems regarding farmer organizations. Formal organizations such as farmer groups and cooperatives are unlikely to perform well due to lack of competent leadership and weak commitment of the members to collective activities. Organizational maturity may improve the functioning of farmer organizations but may not be achieved in the short term. Third, problems regarding the adoption of new production methods by farmers. According to extension officers interviewed, it is not easy to convince farmers to change their production methods when the farmers believe that they feel there is nothing wrong with the methods used (for years). Changing farmers believes and behaviour need gradual processes involving relevant approaches such as effective communication, demonstration plots, and participatory methods that focus on learning by doing. Because of resource constraints, the government has not been able yet to consistently guide the gradual process of change at farmer level to address production problems.

We noted that the aforementioned problems have a rather long history, which to some extent are attributed to the deficiency of extension services in the coffee sector. The role of (government) extension service should therefore be improved, and the government may consider working with knowledge facilitators (e.g., universities and NGOs) with the main aim to change farmers' perspectives and to improve their capacities on production and organization. The government may further need to include other types of knowledge facilitators such as those who work voluntarily in the 
Chapter 5

communities - as independent extension personnel/workers. These people include retired private and government employees - who turn into successful farmers - and skilful farmers such as group leaders. As they live with and are part of farmer communities, independent extension workers have a potential to drive the gradual processes of change at the farmer level, including changing farmers' perspectives. 
Chapter

Conclusion and reflection 


\subsection{Introduction}

Sustainability standards and certification schemes claim that training in good agricultural practices and managerial matters, including the formation and management of well-functioning farmer organizations, will provide benefits for farmers. These benefits can be both tangible (e.g., all exchanges of goods and services, revenues, contracts and payments) and intangible (e.g., knowledge exchange, reputation and feelings of social belonging) in nature. This dissertation analyzes the benefits attached to sustainability standards and certification from a coffee farmer's point of view, with a focus on the Indonesian context. Coffee farmers in Indonesia are rather vulnerable smallholders. They are not well organized due to lack of well-functioning farmer organizations, have insufficient capital to invest in their plantations, meet difficulties in the process of marketing their products and therefore face serious livelihood problems.

Sustainability standards and certification schemes do not only regulate production and processing methods related to better environmental and social conditions of production, but also aim to open opportunities for better market access, improve production capacities of the farmers, improve rural livelihoods, and contribute to poverty alleviation. This dissertation aims to understand the values attached to sustainability standards and certification schemes by coffee-producing smallholders in their relevant contexts. We want to know what values they pursue, how and to what extent these values correspond to the intervention logic of sustainability certifications, and what this implies for the process towards more sustainable coffee production in Indonesia.

This concluding chapter is structured into five sections. Sections 2 and 3 provide a summary of the findings of this dissertation, addressing the values that farmers attach to sustainability standards and certifications reflected by their preferences for certification attributes, explanations for participation in certification, and farmers' perceived benefits related to the membership of different organizations and certification schemes, and the analysis of the implementation and problem-solving capacity of ISCoffee as a government initiative. Section 4 introduces a systemic perspective based on five building blocks to better understand and interpret the pathway towards more sustainable coffee production in Indonesia. Section 5 suggests future directions for research in this field. 


\subsection{Farmers' values regarding sustainability standards and certification schemes}

The sustainability standards and certification schemes present in Indonesia (e.g., Fairtrade, UTZ, Rainforest Alliance, 4C, organic) are developed by, and based on, the preferences of Northern consumers and implemented through multinational roasting companies and/or exporting companies. While certified coffee is promoted to consumers because of environmental and social aspects of sustainability in production, our research in Chapter 2 shows that Indonesian coffee farmers prefer a certification scheme that primarily offers economic benefits. Thus certification, which is meant to be a tool to promote sustainability, becomes, when applied in the field and accepted by the farmers, an economic tool. This does not mean that the Indonesian coffee farmers do not value the environmental and social aspects of their production, but their preferences regarding the certification schemes differ. Moreover, we also found that even farmers who participate in a certification scheme prefer a loose relationship with traders, so that they can easily switch between certified and uncertified markets. This further implies that farmers display a great deal of opportunistic behaviour (see Chapter 2).

Moreover, as the research in Chapter 2 shows, farmers generally have little understanding of the philosophy behind the sustainability concept in agricultural production; they just follow the rules imposed on them. This finding is mirrored in our research on explanations for participation in certification schemes. Among the different explanatory factors that we analyzed in Chapter 3, economic motivations are by far the strongest. These findings should be interpreted in the context of some background disincentives for the uptake of sustainability certifications and the transformation towards more sustainable production. First, there is an overproduction of certified coffee in the current market. This results in a situation where certified coffee is sold on the conventional market. Second, although our research shows that the prospect of a price premium is vitally important for a farmer's decision to participate, certified farmers do not always receive this premium for their certified coffee. Although farmers receive a price premium, the price differential with non-certified coffee is very small. This not only discourages uncertified farmers from joining, but also demotivates certified producers to stay in the programs (see Chapter 3 ). Third, this situation may be further exacerbated by new market trends. Indonesia exports its coffee to Northern (i.e. Western) and Southern (non-Western) markets, but in recent years the latter have surpassed the former as the main export destination for Indonesian coffee. These Southern markets, including the fast-growing domestic market, do not require coffee to be certified. 
A fourth contextual disincentive is declining interest of farmers in coffee production as other crops, like palm oil or cocoa, are perceived as a more profitable investment than coffee. This further decreases investment by the government and private actors in the coffee sector. Finally, we observed that participation in certification is most difficult for the most vulnerable smallholders, who own very small plots and struggle to survive economically, and who live far away from hard-to-access cooperatives or KUBEs (see Chapter 3). Chapter 5 further shows that farmers are generally working with limited support from extension services, which leads to a limited understanding of good agricultural practices among farmers, weak farmer organizations, and resistance to change. The chapter argues that all of these deficiencies further result in smallholders' limited understanding of sustainability in coffee production, and that ISCoffee as a public initiative will likely be unable to address the problems mentioned. Overall, this shows that the current certification systems are weakly institutionalized in farmers' practices, which further contributes to the low rate of certification adoption by smallholders (only 7\% of the exported Indonesian coffee was certified in 2014 (see Chapter 3). The implication is that the coffee sector may require not only standards and certification but also other instruments and/or strategies to lead to sustainability in coffee production.

Our research yielded no indications of a transformation to a more sustainable production in the short term. This also regards the uptake of IScoffee (Indonesian Standards Coffee), which we analyzed in Chapter 5 . The rise of public standards and certifications can be considered a new trend in Indonesia (such as for palm oil and cocoa as well). ISCoffee reflects Southern actors' attempts to establish a counterinitiative because they feel dissatisfied with, or disadvantaged by, the outcomes of the Northern standards and certifications. The Indonesian government uses the national standards and certification to assert the national identity and considers the regulation of the agricultural sector to be its own responsibility. In addition, through the national standards and certifications, the government tries to expand internationals market for agricultural commodities. However, doubts have arisen regarding ISCoffee's ability to become an accepted and viable certification in the international market. Some scholars argue that the Southern standards and certifications may gain relevance in their domestic markets whereas Northern standards and certifications will be more demanded in international trade. Our analysis of the implementation capacity of ISCoffee in Chapter 5 reveals that the implementation capacity of ISCoffee is low, mainly because of weak administrative structures and coordination deficiencies. It will consequently be difficult for ISCoffee to solve smallholder-related problems in the coffee sector, such as limited access to the market, low productivity and quality, and 
underdeveloped farmer organizations. We conclude that in the short term, ISCoffee will not become a viable alternative to Northern-based private standards and certifications.

\subsection{On the relevance of farmer organizations}

Smallholders are embedded in the local economies because their production and consumption mostly take place locally. One of the problems observed is that smallholders often start selling their coffee within the first two weeks after harvest; they have several reasons, but the main reason is to obtain income to meet their basic needs. This implies that many smallholders are not linked to a more profitable market that balances between quality and price. Certification claims to address this issue, but requires smallholders to firstly organize themselves in farmer organizations. As Chapter 4 shows, the manifestations of farmer organizations in Indonesia are diverse. Three types of farmer organizations play a role in the coffee sector: farmer groups (FGs), cooperatives, and Kelompok Usaha Bersama (KUBEs). These organizations have different organizational characteristics since they are supported by different ministries, and are currently regulated by different sets of rules. Our analysis of perceived benefits of certification and farmer organizations from a smallholder's point of view shows that certification creates market opportunities and provides training that improves the farmers' skills and knowledge (capacity building). Trainings mostly take place in a group, which may further strengthen the feeling of belonging to a community and contribute to a higher perception of social benefits in the domain of networking. We found that organizations in which certified farmers participate often lead to more benefits than those of uncertified farmers. The latter are at best only involved in a single organizational structure (FGs), whereas the former have a dual organizational membership that either combines participation in FGs with KUBEs (FGKUBE) or with cooperatives (FGcooperative). Cooperatives are generally larger than KUBEs in terms of assets and/or financial capital. Farmers participating in FGcooperatives and FGKUBEs, however, do not significantly differ in their perceived benefits, and therefore we conclude that these organizations' differences in (financial) assets and capital have no significant influence on farmers' perceived benefits.

The existing farmer organizations seem to perform relatively well in bringing benefits to the farmers and thus creating additional value for their members. The different types of organizations seem complimentary rather than overlapping or conflicting. FGs, for example, enhance farmers' knowledge and skills regarding the technical aspects of coffee production, whereas KUBEs and cooperatives link farmers to certified coffee markets. FGs are more product-oriented, and are valued as a social organization that strengthens communal relationships (among friends and neighbors). The unique value of a KUBE, which is more market-oriented, is that it assists the FGs in complying with 
certification requirements and improving their management. In contrast, cooperatives work with individual farmers and assist them on an individual or cluster basis. Both KUBEs and cooperatives, however, connect farmers to buyers (e.g., exporters or multinational companies) and other farmers (outside their own FGs).

Our main findings on farmer organizations, however, do not change the main picture of a lack of well-functioning farmer organizations which hampers collective activities. As shown in Chapter 5, the problems of farmer organizations are rather difficult to address, due to a lack of attention to the causes of the problems such as incompetent leadership and a lack of motivation among farmers to organize. ISCoffee has the opportunity to improve the roles of farmer organizations, but the problem is that formal organizations such as farmer groups and cooperatives are unlikely to perform well unless they reach a certain level of maturity. In fact, many of them do not function well and may not achieve organizational maturity in the short term. The top-down approach by the government in establishing formal organizations seems to rather ignore these problems.

\subsection{A pathway toward sustainability in the Indonesian smallholder coffee production system}

Sustainability standards and certifications, either private or public, do not improve sustainable coffee production and guarantee better living conditions for smallholders per se. One of the noticeable constraints for farmers to accept sustainability standards and certification relates to the lack of economic incentives. Our findings imply that economic sustainability should be the basis of sustainability in coffee production. There are, however, inherent links between the economic and the social and environmental dimensions of sustainability, which further implies that a systemic view is required to better understand essential factors leading to a more sustainable coffee production. Below we identify these factors and categorize them. They include an enabling environment, production and market characteristics, availability of alternative livelihoods, and the degree of competition among producers. We regard these factors as "building blocks" of a more sustainable coffee production system in which smallholders - as gatekeepers of the system - play important roles (see Figure 6 below). A sustainability pathway therefore refers to the combination of building blocks to drive the current coffee production system towards a more sustainable one. We hypothesize that the smallholder coffee producing system has prospects for growth when the system is managed and coordinated with a focus on improvements in the five building blocks. This is, however, not likely to be the result of a single instrument but of a combination of various instruments to address requirements for each building block. 
Understanding the building blocks may provide stepping stones required to induce a sustainable change in the current coffee production system.

Figure 6. Five building blocks forming a pathway for a more sustainable coffee production system.

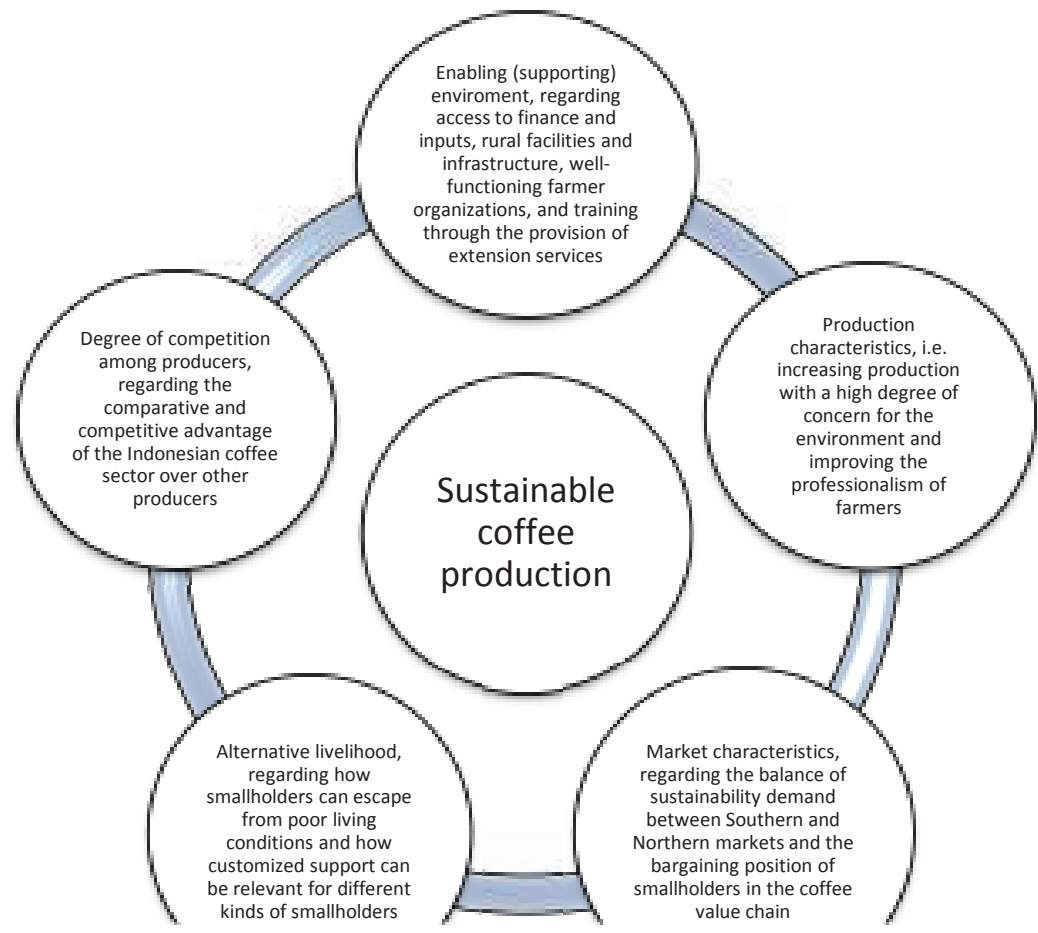

These building blocks have different focuses, and therefore they should be coordinated to drive a systemic change in the coffee sector. Enabling environment refers to the combination of institutions, policies, regulations and infrastructure that provide supports for improving sustainability in coffee production. In Indonesia, however, the enabling environment seems not to be very helpful, as support for the coffee sector is rather limited. For example, as noted in Chapter 5, the government gives priority to staple foods over coffee, which results in inactive policies (e.g., for extension services) and low investments in the coffee sector (e.g., infrastructure, rural facilities). Other issues are that while smallholders produce largely for the domestic and export markets, the productivity and the quality of the coffee produced are relatively low; and among the problems are low professionalism (knowledge and skills in production, processing and marketing) and limited access to finance and affordable inputs. Furthermore, difficult access to remote areas (because of poor conditions of roads) and institutionalized social relationships to a large extent explain why many smallholders are poorly organized and rely on middlemen to market their coffee. 
In the enabling environment building block, institutional changes are therefore needed to focus on instruments that are still lacking, such as access to finance and inputs, rural facilities and infrastructure, well-functioning farmer organizations, and access to training through the provision of extension services. To address limited access to finance and inputs, efforts should be directed to solve a common issue in the coffee sector, which is farmers' reluctance to deal with banks and/or input providers because of administrative requirements. The contrasting issue is that banks and/or credit providers are hesitant to provide credits because agriculture is perceived to be high risk, and consequently require farmers to provide security, which in turn discourages farmers from dealing with the financial providers. These issues seem to be related to each other and efforts to address them need to be backed up by a strong commitment of the government through policies and/or regulations. As the national budget for running programs in the coffee sector is limited, the government should extend partnerships with the private sector to address all of the issues that relate to smallholders and to further develop necessary facilities and infrastructure in rural areas.

FGs, cooperatives, and KUBEs are instruments for collective action, although even without these (formal) organizations collective action is still practicable, for example with informal groups. This further implies that the development of farmer organizations may not need to be standardized or formalized. Instead, a participatory approach should be prioritized in the sense that farmers should be given more opportunities to organize themselves in a way that they prefer. For example, in Indonesia, many informal organizations exist and function relatively well, developed based on local (community) initiatives such as kelompok arisan (community-gathering groups) and paguyuban (informal association). From a technical point of view, empowerment of farmer organizations may further require the unification of various small organizations to become large enough in economies of scale. Until now, however, the enthusiasm of the government in running extension services has not been satisfactory, and this contributes to weak institutional transformation of extension services in the coffee sector. Extension services should therefore be improved through enhanced investments in the quality and quantity of government extension workers and through effective mechanisms for the inclusion of independent and private extension agents in the extension system. 
Production characteristics relate to crop requirements, which have a very direct influence on farmer professionalism. Comparing Robusta and Arabica requirements, the former requires a lower level of processing ${ }^{27}$ knowledge and skills than the latter (i.e., the latter is mostly produced as specialty coffee in Indonesia). Hence, coffee smallholders in Indonesia (and also in Vietnam with more than $80 \%$ Robusta farmers) may have a lower level of professionalism (at least regarding coffee processing) than Arabica farmers, for example in Brazil (with more than $80 \%$ Arabica-producing farmers).

In the production building block, the challenge is to improve production through compliance with sustainability principles and criteria, for example by increasing yields without increased chemical inputs and deforestation. It seems that strategies for improving production are rather different between Arabica and Robusta. For Arabica, besides improving productivity, the challenge is to increase plantation areas. To enhance Arabica plantations, one plausible strategy is to shift production from Robusta to Arabica at certain altitudes. As Arabica is planted at an altitude of 1000-1500 meters and Robusta at 500-1100 meters, it seems that there are areas (between 800 and 1100 meters altitude) that are suitable for Arabica but are currently planted with Robusta. ${ }^{28}$ Such areas across the country should therefore be identified, and an effort should be made to persuade farmers to change their production from Robusta to Arabica. This change of production may further help enhance farmers' professionalism (at least regarding processing method) in producing better-quality coffee. On the other hand, for Robusta, the priority may be to improve the productivity of smallholders' plantations through improved production techniques and rejuvenating old coffee trees. Significant numbers of coffee trees in farmers' plantations are old, and their productivity decreases over time. Farmers usually do what they call stek, which means joining the stem shoots of old coffee trees with the branches of another coffee tree to rejuvenate and increase fruit production of the old trees. This, however, may not result in optimal yields for farmers in the long term, and the old trees eventually need to be rejuvenated with better plantlets. Among the observed challenges is that smallholders often prefer to use coffee plantlets nurtured in their backyards rather than to use coffee plantlets offered by, for example, the government. Farmers are rather skeptical whether the plantlets cloned in different regions, when planted in their plantations, will be able to adapt well to specific local conditions (soil, climate etc.). In this case, it is therefore important to promote a new variety to farmers through, for example, demonstration plots or

\footnotetext{
${ }^{27}$ Arabica requires a wet processing method, which is more complicated and requires more knowledge and skills than Robusta, with a mostly dry processing method.

${ }^{28}$ Robusta productivity may not be fully achieved at an altitude higher than 800 meters above sea level (Dirjen Perkebunan, 2014).
} 
plantation models; if farmers see potential yield improvements, they are likely to adopt it. Another alternative for rejuvenating coffee trees is perhaps with plantlets produced locally by competent nurseries or with strains that can adapt to different geographical conditions, including poor soils. Overall, in line with efforts to improve productivity, concerns regarding the environment cannot be ignored by, for example, maintaining soil fertility through enhanced organic inputs, conserving water through protecting water sources and eliminating chemical waste, and enhancing biodiversity. The latter can be operationalized through an agroforestry system (polyculture) that increases the types (or genetic) of trees in coffee plantations, which further allows farmers to diversify their incomes.

Market characteristics determine the quantity and quality of coffee demanded and the requirements for sustainability standards and certification. The differences between Arabica and Robusta influence not only the level of farming professionalism but also market values for the products, which further determine demand and prices. As Robusta is generally produced with relatively small differences in quality, it is often sold in bulk, and market demand may subsequently focus only on the lowest price. Northern markets tend to demand higher levels of food safety, better quality and impose more stringent sustainability requirements for tropical commodities than most Southern markets do (both for the domestic and export markets). In the market building block, the "balance" between sustainability demands from Southern versus Northern markets is considered an important aspect determining the way coffee is grown in Indonesia. Other key determinants are the dynamics of demand (whether overall demand for coffee is growing or declining) and perceived pressures to secure a stable coffee supply.

The demand for coffee in Southern markets (both domestic and export) is growing. While there is pressure to increase production, sustainable coffee production will not be realized unless the demand for sustainable-certified coffee on the Southern market increases too. The argument is that if demand for sustainable-certified coffee in this market remains low, the incentive to produce coffee in a sustainable way also remains low. To date, demand for sustainable-certified coffee has mostly come from the Northern market, but the portion of Indonesia's coffee exported to this market has gradually been decreasing.

In the market building block, the sustainability of coffee production can therefore be improved by promoting sustainability standards and certification in the Southern market and boosting demand for certified coffee from this market. ISCoffee potentially plays a role in this context, and therefore market players and NGOs, with their experience in the field of sustainability, should help improve the implementation capacity of ISCoffee to allow it to achieve its goal in the Southern domestic and export 
markets. Although ISCoffee has not yet been formally implemented, the central government has taken a further step by collaborating with several NGOs to formulate and launch a "National Curriculum \& Training Manual" for Robusta coffee. This curriculum was launched in 2016, and is intended to be a national reference document for providing training for smallholders to improve their knowledge and skills in good agricultural practices (GAPs) and post-harvest processing (Tabloidsinartani, 2016). The curriculum may strengthen the foundation of ISCoffee in the future but, as indicated earlier, extension services should be improved first. Furthermore, the bargaining position of farmers should be improved, because to some extent, farmers may perceive that they have a relatively better bargaining position when dealing with local traders and/or collectors (middlemen) rather than with multinational market players. This perception may further explain why many farmers, although they are certified, still practice side-selling to conventional coffee markets. The farmers' bargaining position can be improved by, for example, strengthening the capacity of farmer organizations to obtain the certificate for sustainability standards.

Alternative livelihoods refer to opportunities available for smallholders to escape from poor economic conditions. These opportunities may further determine whether cultivating coffee is still attractive for farmers. Smallholders' profits from coffee vary over time, and even though, for example, Arabica farmers in Aceh usually receive higher prices than Robusta farmers in Lampung, this does not mean that their welfare is also higher. This implies that coffee earnings may fail to improve smallholders' welfare, and smallholders may further decide to shift to other crops, change their profession or migrate to the urban environment. If this trend continues, young people may prefer to find jobs in cities and consequently the coffee sector may be managed mostly by aging farmers, which in turn weakens the overall performance of the sector. In addition, without alternative livelihoods, smallholders may be unable to escape from poor living conditions, and they may sell their coffee at low prices which may further lead to oversupply of low-cost, low-quality coffee.

Livelihood conditions vary between smallholders from region to region, implying that smallholders may require customized support. In the livelihood building block, some smallholders may need to build a more commercial farming operation through the combination of FGs, cooperatives and KUBEs. Other farmers, especially the poorest of the poor, may need to be helped to find alternative livelihoods through decent employment opportunities or through non-farming business activities. This further implies that defining smallholders as farmers who spend all their time producing coffee and fully depend on it as a source of income may not be relevant anymore, because it seems to ignore other realities smallholders are facing. Instead, support for farmers should take three types of smallholders into account. First, farmers who obtain their 
income through allocating most of their time and resources to on-farm activities (i.e., full-time coffee farmers). Second, farmers who obtain their income through dividing their time and resources equally between on-farm and off-farm activities (i.e., part-time coffee farmers). Third, farmers who obtain their income through relying more on offfarm activities (i.e., farmers who provide services to the coffee sector). The basic characteristics of the three types of farmers are, however, the same in the sense that their activities are mostly in rural areas and are still related to coffee production, though in different degrees. In addition, investment in public facilities in rural areas, especially schooling, should be carefully designed to change the image of being a farmer (poor, limited choices of technology, market etc.) and attract young people to coffee-farming activities. To show the opportunities offered by the coffee sector, schooling should include the introduction of better technologies in coffee cultivation and in coffee processing as well as discussion of potential markets for coffee products.

In the past couple of decades, we have witnessed a profound geographical expansion of coffee cultivation. This expansion of coffee production influences the degree of competition among producers, both regionally and globally. Indonesia has contributed to this expansion by increasing production and exporting coffee to various countries. The country has been a significant global coffee producer from 1885 (second after Brazil), but by the end of the 1990s it was surpassed by Vietnam, which expanded its Robusta production significantly. At the same time new Robusta producers emerged, such Guyana (in Africa) and Lao People's Democratic Republic (in Asia). On the one hand, this production trend reflects structural changes in the ways in which agriculture in developing countries confronts global markets. On the other hand, it implies that coffee production has become more globalized, with an increased number of producer countries and more intense competition among them. This, however, may result in a sustained decline of commodity prices.

In the degree of competition building block, the concern is how the Indonesian coffee sector can gain comparative and competitive advantage over other producers. As indicated earlier, the Indonesian coffee sector has not reached its full production capacity (i.e., only around $60 \%$ of potential production is realized). This implies that investment in the coffee sector may result in a significant increase in production compared to the same amount of investment in other coffee-producing countries that have nearly reached their full potential production. This can be considered a comparative advantage of the Indonesian coffee sector; therefore, the production capacity of farmers should be improved by applying better production methods that lead to increased productivity and efficiency. Furthermore, because of specific geographical climate conditions that influence, for example, coffee flavor, nearly all islands or regions in the country where coffee is grown could produce different types of 
specialty coffee. Both Arabica and Robusta varieties with unique characteristics (e.g. in terms of taste or aroma) can be regarded as specialty coffee, which is appreciated for its high quality. Indonesian Robusta specialty coffee, for example, may be qualitatively differentiated compared with Robusta from other producers, which may also lead to higher prices. This can be considered a competitive advantage for Indonesian coffee that should be explored further. There are opportunities to develop this niche market further for both Arabica and Robusta specialty coffees. Potential opportunities include applying geographical indication (GI), which attaches specific attributes (terroir, ${ }^{29}$ taste, production method) to coffee. The GI provides assurance for consumers that coffee with the label is a specialty. Robusta lags Arabica in terms of $\mathrm{Gl}$; consequently, solid collaboration between coffee stakeholders, especially relevant intermediaries, will be needed to identify markets for Robusta specialty coffee.

\subsection{On future studies}

Achieving sustainability in coffee production will require a combination of intervention strategies and/or instruments derived from all of the building blocks to realize a systemic change in the smallholder coffee production system. To develop more effective intervention strategies and/or instruments, we provide some recommendations for future studies based on our empirical research. First, sustainability standards should be made more accessible to smallholders, and one way might be to work towards harmonization of standards, as the current situation is rather confusing for them. Very recently RA and UTZ decided to merge, and this may be one step in the right direction. Future research could look at how the harmonization of standards could lead to a single internationally agreed set of standards. Based on that set of standards, specialties could be further differentiated. Future studies also need to explore how national standards, such as ISCoffee, can provide a stepping stone towards globally accepted standards.

Second, the quantity and quality of farmers' production should be improved, for example through better provision of extension services. Currently, extension services in the sector are rather scarce. Future studies may need focus on the design of an extension system that makes it possible to effectively balance competing factors, for example the environment and the economy.

\footnotetext{
${ }^{29}$ Terroir is "a concept with different definitions but essentially connotes a geographical area with certain special characteristics including natural conditions such as soils, vegetation and water quality, and particular cultures and production techniques that result in products with specially valued tastes and other attributes" (Blackmore et al., 2012).
} 
Third, since market demand has a significant effect on the uptake of sustainability standards and certification, increasing this demand will be a crucial success factor for scaling up sustainability standards and certification and creating an incentive to produce more sustainable coffee. Future studies should therefore pay attention to opportunities to improve the marketing system that may lead to greater demand for sustainable products.

Fourth, organizing farmers is important to improve their agency and is required for certification. Despite their formal status, farmer organizations tend to lack effective management and resources, and they vary highly in terms of their organizational capacity. Future research may need to firstly identify and categorize producer organizations based on their capacity. Well-defined categories are useful to map the existing farmer organizations and, if capacity development is necessary, the categories may be used to evaluate progress resulting from training and other learning processes.

Fifth, the adoption of sustainability standards and certification by farmers is mainly driven by a combination of market access and price premium. As indicated earlier, however, sustainability standards and certification are operating in the context of oversupply or limited demand for certified coffee and uncertainty about price premiums. This implies that, to remain inclusive (i.e., provide benefits for farmers), future studies need to focus on how sustainability standards and certifications can embrace business models that have, for example, greater economic relevance for farmers. Furthermore, future studies can increase their focus on production-related issues such as how farmers can cope with climate change (e.g., increased temperature, less rainfall etc.) and mitigate the risks of crop failures, and how women's participation in the coffee value chain can be improved.

Finally, future studies may need to evaluate the interplay between sustainability standards and certification and other instruments in the building blocks, and their impacts on sustainability in coffee production. This may provide additional insights into the synergies between sustainability standards and certification and other instruments, for example between certification and government policies. In this way, future studies can further develop a framework for action based on a pathway toward a more sustainable coffee production system. 


\section{References}

Adesina, A. A., \& Baidu-Forson, J. (1995). Farmers' perceptions and adoption of new agricultural technology: evidence from analysis in Burkina Faso and Guinea, West Africa. Agricultural economics, 13 (1), 1-9. doi: 10.1016/0169-5150 (95)01142-8.

Adong, A. (2014). Impact of households' membership of farmer groups on the adoption of agricultural technologies in Uganda: Evidence from the Uganda Census of Agriculture 2008/09. Agrekon, 53(2), 108-136. doi: 10.1080/03031853.2014.915485.

Agro-Industri. (2016). Secangkir kopi bubuk Indonesia di Dublin. Edisi Oktober-desember 2016. Kementerian Perindustrian Republik Indonesia.

Agterbosch, S., Meertens, R. M., \& Vermeulen, W. J. (2009). The relative importance of social and institutional conditions in the planning of wind power projects. Renewable and Sustainable Energy Reviews, 13(2), 393-405. doi: DOI: 10.1016/j.rser.2007.10.010.

Agustian, A., \& Rachman, B. (2015). Penerapan teknologi pengendalian hama terpadu pada komoditas perkebunan rakyat. Perspektif, 8(1), 30-41.

AICE. (2015). Peninjauan kembali peraturan pemerintah RI Nomor 2 tahun 1996 tentang kegiatan perusahaan yang didirikan dalam rangan penanaman modal asing di bidang ekspo dan impor. Unpublished letter to the national government.

AICE. (2015). Revitalisasi perkopian di daerah Lampung. Unpublished report.

Anggraeni, T. (2014). Menciptakan Sistem Pelayanan Publik yang Baik: Strategi Reformasi Birokrasi dalam Pemberantasan Korupsi. Jurnal Rechtsvinding, 3(3), 417-433.

Arifin, B. (2017). Coffee Eco-Certification: New Challenges on Farmers' Welfare. Book Chapter in Richard Barichello and Richard Schwindt (eds), Coordinated Compliance of Trade Policy and Dilemmas of Poverty/Inequality. New York: Routledge.

Arifin, B. (2008). Non-State Regulation of Agricultural Trade: The Case of Lampung Coffee. Paper presented at the Seminar of Indonesia Study Group (ISG) of Australian National University (ANU), Canberra, Australia. Retrieved May 21, 2013 from http://barifin.files.wordpress.com/2012/12/2008-arifin-non-stateregulation-of-coffee-trade-in-indonesia.pdf.

Arifin, B. (2010). Global Sustainability Regulation and Coffee Supply Chains in Lampung Province, Indonesia. Asian Journal of Agriculture and Development. Southeast Asian Regional Center for Graduate Study and Research in Agriculture. Vol. 7(2), pages 67-89.

Arifin, B., Swallow, B. M., Suyanto, S., \& Coe, R. D. (2009). A conjoint analysis of farmer preferences for community forestry contracts in the Sumber Jaya Watershed, Indonesia. Ecological Economics, 68(7), 2040-2050. doi: 10.1016/j.ecolecon.2008.12.007.

Arifin, B., van Noordwijk, M., Glasbergen, P., Ibnu, M., Astuti, E.S. (forthcoming). Coffee Eco-Certification in Indonesia: Trends and Reorientation. Submitted to 


\section{References}

International Journal of Biodiversity Science, Ecosystem Services \& Management.

Arnould, E., Plastina, A., \& Ball, D. (2009). Does Fairtrade deliver on its core value proposition? Effects on income, educational attainment, and health in three countries. Journal of Public Policy and Marketing 28(2): 186-201. doi: 10.1509/jppm.28.2.186.

Ashby, J., Heinrich, G., Burpee, G., Remington, T., Wilson, K., Quiros, C. A., . . Ferris, S. (2009). What farmers want: collective capacity for sustainable entrepreneurship. International Journal of Agricultural Sustainability, 7(2), 130146. doi: 10.3763/ijas.2009.0439

Astuti, E. S, Offermans, A., Kemp, R., \& Corvers, R. (2015). The Impact of Coffee Certification on the Economic Performance of Indonesian Actors. Asian Journal of Agriculture and Development, 12 (2), 1-15.

Auld, G. (2010). Assessing Certification as Governance: Effects and Broader Consequences for Coffee. The Journal of Environment and Development, 19(2), 215-241. doi: 10.1177/1070496510368506.

Bacon, C. (2005). Confronting the coffee crisis: can Fairtrade, organic, and specialty coffees reduce small-scale farmer vulnerability in northern Nicaragua? World Development, 33(3), 497-511. doi: doi:10.1016/j.worlddev.2004.10.002.

Bacon, C. M. (2010). Who decides what is fair in fair trade? The agri-environmental governance of standards, access, and price. The Journal of Peasant Studies, 37(1), 111-147. doi: 10.1080/03066150903498796.

Bacon, C. M., Ernesto Méndez, V., Gómez, M. E. F., Stuart, D., and Flores, S. R. D. (2008). Are Sustainable Coffee Certifications Enough to Secure Farmer Livelihoods? The Millenium Development Goals and Nicaragua's Fair Trade Cooperatives. Globalizations, 5(2), 259-274. doi: 10.1080/14747730802057688.

Bakken, D., and Frazier, C. L. (2006). Conjoint Analysis: Understanding Consumer Decision Making. In R. Grover and M. Vriens (Eds.), The Handbook of Marketing Research: Uses, Misuses, and Future Advances (pp. 720 pages ). California: Sage Publication.

Barbosa de Lima, A., Keppe, A. N., Maule, F., Sparovek, G., Alves, M. C., \& Maule, R. (2009). Does certification make a difference? Impact assessment study on FSC/SAN certification in Brazil. Published by Imaflora, Sao Paulo, Brazil. Retrieved June 22, 2013, from http://www.imaflora.org/downloads/biblioteca/Does_certification_make_a_di fference.pdf.

Barry, M., Cashore, B. Clay, J. Fernandez, M. Lebel, L. Lyons, T., \& ... Fish, JK (2012). Toward Sustainability: the roles and limitations of certification, Final Report. Prepared by the Steering Committee of the State of Knowledge Assessments of Standards and Certification, Washington, DC.

Becchetti, L., \& M.Costantino. (2008). "The effects of fair trade on affiliated producers: An impact analysis on Kenyan farmers." World Development no. 36 (5):823842. doi: http://dx.doi.org/10.1016/j.worlddev.2007.05.007.

Bekele, W. (2006). Analysis of Farmers' Preferences for Development Intervention Programs: A Case Study of Subsistence Farmers from East Ethiopian Highlands. 
African Development Review, 18(2), 183-204. doi: 10.1111/j.14678268.2006.00138.x.

Berdegué, J. A., \& Fuentealba, R. (2011, January). Latin America: The state of smallholders in agriculture. In IFAD conference on new directions for smallholder agriculture (Vol. 24, p. 25). Retrieved May 21, 2013 from http://www.agriculturafamiliarperu.pe/wpcontent/uploads/2014/07/01.2011_FIDA_Berdegue_Fuentealba_Peque\%C3\%B 1os-agricultores-en-AmLatina.pdf.

Berk, R. A. (1983). An introduction to sample selection bias in sociological data. American Sociological Review, 386-398.

Bernstein, S. (2011). Legitimacy in intergovernmental and non-state global governance. Review of International Political Economy, 18(1), 17-51. doi: 10.1080/09692290903173087.

Bernstein, S., \& Cashore, B. (2007). Can non-state global governance be legitimate? An analytical framework. Regulation \& Governance, 1(4), 347-371. doi: 10.1111/j.1748-5991.2007.00021.x.

Beuchelt, T. D., and Zeller, M. (2011). Profits and poverty: Certification's troubled link for Nicaragua's organic and fairtrade coffee producers. Ecological Economics, 70(7), 1316-1324. doi: 10.1016/j.ecolecon.2011.01.005.

Beuchelt, T., \& Zeller, M. (2013). The role of cooperative business models for the success of smallholder coffee certification in Nicaragua: A comparison of conventional, organic and Organic-Fairtrade certified cooperatives. Renewable Agriculture and Food Systems, Vol 28 (3): 195-211. doi: $10.1017 /$ S1742170512000087.

Birol, E. Villalba, E.R., \& Smale, M. (2009).Farmer preferences for milpa diversity and genetically modified maize in Mexico: a latent class approach. Environment and Development Economics, 14(04), 521-540. doi: 10.1017/S1355770X08004944.

Bitzer V. (2011). Partnering for Change in Chains: on the capacity of partnerships to promote sustainable change in global agricultural commodity chains. PhD dissertation. ICIS Maastricht University- the Netherlands.

Bitzer, V., \& Glasbergen, P. (2015). Business-NGO partnerships in global value chains: part of the solution or part of the problem of sustainable change? Current Opinion in Environmental Sustainability, 12, 35-40. doi: http://dx.doi.org/ 10.1016/j.cosust.2014.08.012.

Bitzer, V., Francken, M., \& Glasbergen, P. (2008). Intersectoral partnerships for a sustainable coffee chain: Really addressing sustainability or just picking (coffee) cherries? Global Environmental Change, 18(2), 271-284. doi: 10.1016/j.gloenvcha.2008.01.002.

Bitzer, V., Glasbergen, P., \& Arts, B. (2013). Exploring the potential of intersectoral partnerships to improve the position of farmers in global agrifood chains: findings from the coffee sector in Peru. Agriculture and Human Values, 30(1), 5-20. doi: 10.1007/s10460-012-9372-z.

Blackman, A., \& Rivera, J. (2011). Producer-level benefits of sustainability certification. Conservation Biology, 25(6), 1176-1185. doi: 10.1111/j.15231739.2011.01774.x. 


\section{References}

Blackmore, E., Keeley, J., Pyburn, R., Mangnus, E., Chen, L., \& Yuhui, Q. (2012). Assessing the benefits of sustainability certification for small-scale farmers in Asia. IIED Natural Resource Issues, London: International Institute for Environment and Development. Retrieved January 26, 2017 from http://pubs.iied.org/pdfs/14604IIED.pdf.

Boyle, K. J., Holmes, T. P., Teisl, M. F., \& Roe, B. (2001). A comparison of conjoint analysis response formats. American Journal of Agricultural Economics, 83(2), 441-454. doi:10.1111/0002-9092.00168.

BPS-statistics Indonesia (2013). Jumlah rumah tangga usaha perkebunan dan luas tanamam/luas tanam menurut jenis tanaman. Retrieved January 15, 2017 from https://st2013.bps.go.id/dev2/index.php/site/tabel?tid=49\&wid=0.

BPS-statistics Indonesia. (2016). Negara-negara tujuan ekspor kopi Indonesia. Retrieved January 21, 2017 from https://www.bps.go.id/linkTabelStatis/view/id/1014.

Bracken, S. S., \& Fischel, J. E. (2006). Assessment of preschool classroom practices: Application of Q-sort methodology. Early Childhood Research Quarterly, 21(4), 417-430. doi: 10.1016/j.ecresq.2006.09.006.

Brandi, C., Cabani, T., Hosang, C., Schirmbeck, S., Westermann, L., \& Wiese, H. (2013). Sustainability certification in the Indonesian palm oil sector: benefits and challenges for smallholders. Bonn, Germany: The German Development Institute.

Brant, R. (1990). Assessing Proportionality in the Proportional Odds Model for Ordinal Logistic Regression. Biometrics, 46(4), 1171-1178. doi: 10.2307/2532457.

Bravo, C. P., Spiller, A., \& Villalobos, P. (2012). Are organic growers satisfied with the certification system? A causal analysis of farmers' perceptions in Chile. International Food and Agribusiness Management Review, 15(4).

Bray, D. B., Sanchez, J. L. P., \& Murphy, E. C. (2002). Social dimensions of organic coffee production in Mexico: lessons for eco-labeling initiatives. Society \&Natural Resources, 15(5), 429-446. doi: 10.1080/08941920252866783.

Bridges, J., Onukwugha, E., Johnson, F., \& Hauber, A. (2007). Patient preference methods-a patient centered evaluation paradigm. ISPOR connections, 13(6), 47.

BSN. (2014). Biji Kopi berdasarkan SNI 2907:2008. Retrieved April 28, 2014, from http://sisni.bsn.go.id/index.php?/sni_main/sni/detail_sni/7670.

Bushway, S., Johnson, B. D., \& Slocum, L. A. (2007). Is the magic still there? The use of the Heckman two-step correction for selection bias in criminology. Journal of Quantitative Criminology, 23(2), 151-178. Doi: 10.1007/s10940-007-9024-4

Calcaterra, E. (2013). Defining Smallholders: Suggestion for RSB smallholders definition.

Calo, M., \& Wise, T. A. (2005). Revaluing peasant coffee production: Organic and fair trade markets in Mexico. Global Development and Environment Institute, Tufts University. Retrieved August 17, 2014 from http://ase.tufts.edu/gdae/pubs/rp/RevaluingCoffee05.pdf.

Carlson, A., \& Palmer, C. (2016). A qualitative meta-synthesis of the benefits of ecolabeling in developing countries. Ecological Economics, 127, 129-145. doi: 10.1016/j.ecolecon.2016.03.020. 
Carson, Richard T; \& Flores, Nicholas A. (2000). Contingent Valuation: Controversies and Evidence. Department of Economics, UCSD. UC San Diego: Department of Economics, UCSD. Retrieved from: https://escholarship.org/uc/item/75k752s7.

Cashore, B. (2002). Legitimacy and the privatization of environmental governance: How non-state market-driven (NSMD) governance systems gain rule-making authority. Governance, 15(4), 503-529. doi: 10.1111/1468-0491.00199.

CFC. (2000). Study of Marketing and Trading Policies and Systems in Selected Coffee Producing Countries. Technical Paper No. 3. Retrieved January 21, 2013 http://www.common-

fund.org/fileadmin/user_upload/Publications/Technical/Coffee/Technical_Pap er_No._3.pdf.

Chandler, G. N., \& Hanks, S. H. (1998). An examination of the substitutability of founders human and financial capital in emerging business ventures. Journal of Business Venturing, 13(5), 353-369. doi: 10.1016/S0883-9026(97)00034-7.

Chiputwa, B., Spielman, D. J., \& Qaim, M. (2015). Food Standards, Certification, and Poverty among Coffee Farmers in Uganda. World Development, 66(0), 400412. doi: 10.1016/j.worlddev.2014.09.006.

Comfort, L. K. (2007). Crisis management in hindsight: Cognition, communication, coordination, and control. Public Administration Review, 67(s1), 189-197. doi: 10.1111/j.1540-6210.2007.00827.x.

Curry, S. J. (2000). Organizational interventions to encourage guideline implementation. CHEST Journal, 118(2_suppl), 40S-46S.

De Blasio, G. G. (2006). Coffee as a Medium for Ethical, Social, and Political Messages: Organizational Legitimacy and Communication. Journal of Business Ethics, 72(1), 47-59. doi: 10.1007/s10551-006-9155-9.

De Graaff, J. (1986). The economics of coffee. Centre for Agricultural Publishing and Documentation (Pudoc), Wageningen, the Netherlands.

De Graaff, J., A. Amsalu, F. Bodnár, A. Kessler, H. Posthumus, \& A. Tenge. (2008). Factors influencing adoption and continued use of long-term soil and water conservation measures in five developing countries. Applied Geography no. 28 (4):271-280. doi:10.1016/j.apgeog.2008.05.001.

de Wolf, C. (2013). Lessons Learned and Opportunities for Scaling-up of Successful Models of Value Chain Development for Smallholder Coffee, Cocoa and Tea in Indonesia. World Bank. May, 30.

Devas, N. (1997). Indonesia: what do we mean by decentralization? Public Administration and Development, 17(3), 351-367. doi: 10.1002/(SICI)1099162X(199708)17:3<351::AID-PAD955>3.0.CO;2-J.

Dieperink, C., Brand, I., \& Vermeulen, W. (2004). Diffusion of energy-saving innovations in industry and the built environment: Dutch studies as inputs for a more integrated analytical framework. Energy Policy, 32(6), 773-784. doi: 10.1016/S0301-4215(02)00341-5.

Ditjebun. 2017. Pengembangan Kopi Arabika Terus Ditingkatkan. Retrieved May 27, 2017

from http://ditjenbun.pertanian.go.id/berita361pengembangankopiarabikaterusditi ngkatkan.htm 


\section{References}

Ditjenbun. (2013). Pentingnya ISCOffee (Indonesian Sustainable Coffee). Retrieved November $\quad 01, \quad 2016$ from http://ditjenbun.pertanian.go.id/pascapanen/berita214pentingnyaiscoffeeindo nesiansustainablecoffee.html.

Dixon, J., Taniguchi, K., Wattenbach, H., \& Tanyeri-Arbur, A. (2010). Smallholders, globalization and policy analysis. AGSF Occasional Paper 5. Retrieved January 21, 2017 from http://www.fao.org/docrep/007/y5784e/y5784e00.htm.

Elder, S. D., Zerriffi, H., \& Le Billon, P. (2012). Effects of Fair Trade certification on social capital: The case of Rwandan coffee producers. World Development, 40(11), 2355-2367. doi: 10.1016/j.worlddev.2012.06.010.

Ellis, W., Panyakul, V., Vildozo, D., \& Kasterine, A. (2006). Strengthening the export capacity of Thailand's organic agriculture. Geneva: International Trade Centre. Retrieved September 17, 2013, from https://www.researchgate.net/profile/Vitoon_Panyakul/publication/23712607 3_Strengthening_the_Export_Capacity_of_Thailand's_Organic_Agriculture/link s/561bbb8d08aea80367242ca2.pdf.

FAO. (2010). Methodologies for Assessing Socio-Economic Benefits of European Inland Recreational Fisheries. European Inland Fisheries Advisory Commission (EIFAC) Occasional Paper No. 46. Retrieved September 14, 2013, from https://www.fao.org/docrep/013/i1723e/i1723e00.htm.

Fransen, L. (2015). The politics of meta-governance in transnational private sustainability governance. Policy Sciences, 48(3), 293-317. doi: 10.1007/s11077-015-9219-8.

FT. (2017). Aims of Fairtrade Standards. Retrieved, January 15, 2017 from https://www.fairtrade.net/standards/aims-of-fairtrade-standards.html.

FT. (2014). Fairtrade standard for small producer organizations. Retrieved June 21, 2017 from

https://www.fairtrade.net/fileadmin/user_upload/content/2009/standards/do cuments/generic-standards/SPO_EN.pdf.

GCP. (2017). 4C Baseline common code v.2.1. Retrieved, January 15, 2017 from http://www.globalcoffeeplatform.org/assets/files/GCP_Doc_01_BaselineCommon-Code_v2.1_en.pdf.

Getz, C., \& Shreck, A. (2006). What organic and Fair Trade labels do not tell us: towards a place-based understanding of certification. International Journal of Consumer Studies, 30(5), 490-501. doi: 10.1111/j.1470-6431.2006.00533.x.

Getz, C., and Shreck, A. (2006). What organic and Fair Trade labels do not tell us: towards a place-based understanding of certification. International Journal of Consumer Studies, 30(5), 490-501. doi: 10.1111/j.1470-6431.2006.00533.x.

Giovannucci, D., \& Ponte, S. (2005). Standards as a new form of social contract? Sustainability initiatives in the coffee industry. Food policy, 30(3), 284-301. doi: 10.1016/j.foodpol.2005.05.007.

Giovannucci, D., Potts, J., Killian, B., Wunderlich, C., Soto,G., Schuller, S., Pinard, F., Schroeder, K., Vagneron, I. (2008). Seeking Sustainability: COSA Preliminary Analysis of Sustainability Initiatives in the Coffee Sector. Committee on Sustainability Assessment: Winnipeg, Canada. 
Giovannucci, D., Von Hagen, O., \& Wozniak, J., (2014). Corporate social responsibility and the role of voluntary sustainability standards. Voluntary Standard Systems (pp. 359-384). Springer Berlin, Heidelberg.

Glasbergen, P. (2007). Setting the scene: the partnership paradigm in the making. In: P. Glasbergen, F. Biermann and A.P.J. Mol (eds) Partnerships, Governance and Sustainable Development: Reflections on Theory and Practice, Cheltenham, UK/Northampton, USA: Edward Elgar: 1-28.

Glasbergen, P. (2013). Legitimation of Certifying Partnerships in the Global Market Place. Environmental Policy and Governance, 23(6), 354-367. doi: 10.1002/eet.1625.

Glasbergen, P., \& Schouten, G. (2015). Transformative capacities of global private sustainability standards. The Journal of Corporate Citizenship, 58, 85-101. doi: 10.9774/GLEAF.4700.2015.ju.00010.

Glasbergen, P., 2007. 'Setting the scene: the partnership paradigm in the making' in Glasbergen, P., Biermann, F. and Mol, A.P.J., eds., Partnerships, Governance and Sustainable Development. Reflections on Theory and Practice. Edward Elgar, Cheltenham, UK; Northampton, USA, 1-28.

Gray, A., \& Jenkins, B. (2006). From public administration to public management: Reassessing a revolution?. In Comparative Public Administration (pp. 543-572). Emerald Group Publishing Limited.

Green, P.E., Wind, J., and Rao, V. R. (1999). Conjoint Analysis: Methods and Applications, In Dorf, R. C. (Ed.) Technology Management Handbook (pp. 6572). CRC Press.

Guei, R. G., Barra, A., \& Silué, D. (2011). Promoting smallholder seed enterprises: quality seed production of rice, maize, sorghum and millet in northern Cameroon. International Journal of Agricultural Sustainability, 9(1), 91-99. doi: 10.3763/ijas.2010.0573.

Guijarro, L. (2007). Interoperability frameworks and enterprise architectures in egovernment initiatives in Europe and the United States. Government Information Quarterly, 24(1), 89-101. doi:10.1016/j.giq.2006.05.003.

Haefele, M. A., and Loomis, J. B. (1999). A Comparison of Conjoint Ratings and Rankings: An Application for Passive Use Values of Forest Health. Paper presented at the Western Agricultural Economics Association Annual Meeting July 11-14 1999, Fargo, ND. Retrieved July 15, 2013 from http://ageconsearch.umn.edu/bitstream/35729/1/sp99ha02.pdf.

Harrison, R. W., Ozayan, A., and Meyers, S. P. (1998). A Conjoint Analysis of New Food Products Processed from underutilized Small Crawfish. Journal of Agricultural and Applied Economics, 30(2), 257-265. Retrieved July 15, 2013 from http://ageconsearch.umn.edu/bitstream/15552/1/30020257.pdf.

Haryati R. (2013). Kebijakan penaganan kemiskinan melalui kelompok usaha bersama/KUBE. Jurnal Pusat Penelitian dan Pengembangan Kesejahteraan Sosial Kementerian Sosial Republik Indonesia. Accessed November 2015, 20 from

http://puslit.kemsos.go.id/upload/post/files/d7cf2b1b50216f2e0e5dd0d6b3d4 95cb.pdf. 


\section{References}

Hellin, J., Lundy, M., \& Meijer, M. (2009). Farmer organization, collective action and market access in Meso-America. Food Policy, 34(1), 16-22. doi: 10.1016/j.foodpol.2008.10.003.

Henson, S., \& Jaffee, S. (2008). Understanding developing country strategic responses to the enhancement of food safety standards. The World Economy, 31(4), 548568. doi: 10.1111/j.1467-9701.2007.01034.x

Hidayat, N.K., Offermans, A., \& Glasbergen, P. (2016). On The Profitability of Sustainability Certification: An Analysis among Indonesian Palm Oil Smallholders. Journal of economics and sustainable development, 7(18), 45-62.

Hidayat, N.K., Offermans, A., \& Glasbergen, P. (forthcoming). Sustainable palm oil as a public responsibility? On the governance capacity of the Indonesian standard for sustainable palm oil (ISPO).

Ho, R. (2006). Handbook of univariate and multivariate data analysis and interpretation with SPSS. CRC Press.

Hoebink, P. R. J., Ruben, R., Elbers, W. J., \& van Rijsbergen, B. J. (2014). The impact of coffee certification on smallholder farmers in Kenya, Uganda and Ethiopia. Retrieved on June 14, 2015 from http://www.ru.nl/publish/pages/721725/final_report_solidaridad_impact_stud y_east_africa_290114.pdf.

Hoffmann, U., \& Grothaus, F. (2015). Assuring Coherence between the Market-access and Livelihood Impact of Private Sustainability Standards. United Nations Forum on Sustainability Standards (UNFSS), CH-Geneva. Retrieved on June 14, 2015 from http://www.fao.org/3/a-i3421e.pdf.

Holagh, S. R., Noubar, H. B. K., \& Bahador, B. V. (2014). The effect of organizational structure on organizational creativity and commitment within the iranian municipalities. Procedia-Social and Behavioral Sciences, 156, 213-215. doi: 10.1016/j.sbspro.2014.11.175.

Holzapfel, S., \& Wollni, M. (2014). Is GlobalGAP Certification of Small-Scale Farmers Sustainable? Evidence from Thailand. The Journal of Development Studies, 50(5), 731-747. doi: 10.1080/00220388.2013.874558.

Ibanez, M., \& Blackman, A. (2016). Is Eco-Certification a Win-Win for Developing Country Agriculture? Organic Coffee Certification in Colombia. World Development, 82, 14-27. doi: 10.1016/j.worlddev.2016.01.004.

IBM Corp. (2010). IBM SPSS Conjoint, Version 19.0. Armonk, NY: IBM Corp.

Ibnu, M., Glasbergen, P., Offermans, A., \& Arifin, B. (2015). Farmer Preferences for Coffee Certification: A Conjoint Analysis of the Indonesian Smallholders. Journal of Agricultural Science, 7(6). doi: 10.5539/jas.v7n6p20.

Ibnu, M., Offermans, A., Glasbergen, P., \& Ismono, H. (2016). Competing Explanations for Indonesian Smallholder Participations in Sustainability Coffee Certifications. Journal of economics and sustainable development, 7(24), 123136.

Ibnu, M., Offermans, A., \& Glasbergen, P. (forthcoming). Perceived impacts of certification and farmer organization: benefits from the Indonesian smallholders' point-of-view. Submitted to Bulletin of Indonesian Economic Studies. 
Ibnu, M., Offermans, A., \& Glasbergen, P. (forthcoming). The public Indonesian standard on sustainable coffee: an exploration of its implementation capacity. Submitted to Asian Journal of Agriculture and Development.

ICO. (2017). Trade Statistics. Retrieved January 19, 2017, from http://www.ico.org/trade_statistics.asp?section=Statistics.

IFAD and UNEP. (2013). Smallholders, food security, and the environment. Retrieved January 17, 2017 from http://www.unep.org/pdf/SmallholderReport_WEB.pdf

IFAD. (2009). Smallholder Farming in Transforming Economies of Asia and the Pacific: Challenges and Opportunities. Retrieved January 17, 2017 from https://www.ifad.org/documents/10180/a194177c-54b7-43d0-a82e9bad64b76e82.

IFAD. (2014). Investing in smallholder family farmers... for the future we want. Retrieved January 17, 2017 from https://www.ifad.org/documents/10180/f484c453e248-483c-871b-b0acb14bf894.

Illukpitiya, P., \& Gopalakrishnan, C. (2004). Decision-making in soil conservation: application of a behavioral model to potato farmers in Sri Lanka. Land Use Policy, 21(4), 321-331. doi: 10.1016/j.landusepol.2003.09.006.

Indraningsih, K.S., H. Supriadi, B. Prasetyo, C. Muslim. (2015). Analisis Kebijakan Implementasi Program Pemberdayaan Masyarakat Perdesaaan. Pusat Sosial Ekonomi dan Kebijakan Pertanian Badan Peneliti dan Pengembangan Pertanian Kementerian Pertanian. Retrieved January 18, 2017, from http://pse.litbang.pertanian.go.id/ind/pdffiles/anjak_2015_10.pdf.

INOFICE. (2007). Hidup organis, sejahtera dan sehat selaras dengan alam. Retrieved January 15, 2014, from http://inofice.tripod.com/index.html.

ITC. (2010). Market Access, Transparency and Fairness in Global Trade: Export Impact For Good 2010. Geneva: ITC, 2010. xi, 144 p. Retrieved March 20, 2013 from http://www.intracen.org/uploadedFiles/intracenorg/Content/Publications/Mar ket-access-transparency-fairness-in-global-trade-Export-Impact-for-Good2010.pdf.

Jaffee, S., (2003). From challenge to opportunity: transforming Kenyan fresh vegetable trade in the context of emerging food safety and other standards. Agriculture and Rural Development Working Paper 10. World Bank, Washington, DC.

Jena, P. R., Chichaibelu, B. B., Stellmacher, T., \& Grote, U. (2012). The impact of coffee certification on small-scale producers' livelihoods: a case study from the Jimma Zone, Ethiopia. Agricultural economics, 43(4), 429-440. doi: 10.1111/j.15740862.2012.00594.x.

Jena, P. R., Stellmacher, T., \& Grote, U. (2015). Can coffee certification schemes increase incomes of smallholder farmers? Evidence from Jinotega, Nicaragua. Environment, Development and Sustainability. doi: 10.1007/s10668-015-97320 .

Kaganzi, E., Ferris, S., Barham, J., Abenakyo, A., Sanginga, P., \& Njuki, J. (2009). Sustaining linkages to high value markets through collective action in Uganda. Food Policy, 34(1), 23-30. doi: 10.1016/j.foodpol.2008.10.004. 


\section{References}

Kaplinsky, R. (2004). Competitions Policy and the Global Coffee and Cocoa Value Chains. Paper prepared for United Nations Conference for Trade and Development (UNCTAD). Institute of Development Studies University of Sussex, and Centre for Research in Innovation Management, University of Brighton. Retrieved March 20, 2013 from http://www.acp-eu-trade.org/library/files/KaplinskyRaphael_EN_052005_IDS_Competition-policy-and-the-global-coffee-andcocoa-value-chains.pdf.

Kaplinsky, R., \& Morris, M. (2001). A handbook for value chain research (Vol. 113): IDRC Ottawa.

Kelly, J. M. (2005). The Dilemma of the Unsatisfied Customer in a Market Model of Public Administration. Public Administration Review, 65(1), 76-84. doi: 10.1111/j.1540-6210.2005.00432.x.

Kessler, C. A. (2006). Decisive key-factors influencing farm households' soil and water conservation investments. Applied Geography, 26(1), 40-60.doi: 10.1016/j.apgeog.2005.07.005.

Kilian, B., Pratt, L., Jones, C., \& Villalobos, A. (2004). Can the private sector be competitive and contribute to development through sustainable agricultural business? A case study of coffee in Latin America. International Food and Agribusiness Management Review, 7(3), 21-45.

Kilpatrick, S. (2007). Building Social Capital in Groups: Facilitating Skill Development for Natural Resource Management. Rural Society, 17(3), 248-257. doi: 10.5172/rsj.351.17.3.248

Kolk, A. (2013). Mainstreaming sustainable coffee. Sustainable Development, 21(5), 324337. doi: $10.1002 /$ sd.507.

Kumar, A., Singh, H., Kumar, S., \& Mittal, S. (2011). Value Chains of Agricultural Commodities and their Role in Food Security and Poverty Alleviation - A Synthesis. Agricultural Economics Research Review Vol. 24 January-June 2011 pp 169-181.

Kusnadi, D. (2011). Dasar-dasar penyuluhan pertanian. Modul Dasar-Dasar Penyuluhan Pertanian STPP. Bogor, Indonesia.

Lawson, B., \& Samson, D. (2001). Developing innovation capability in organizations: a dynamic capabilities approach. International journal of innovation management, 5(03), 377-400.

Lee, J., Gereffi, G., \& Beauvais, J. (2012). Global value chains and agrifood standards: challenges and possibilities for smallholders in developing countries. Proceedings of the National Academy of Sciences of the United States of America, 109(31), 12326-12331. doi: 10.1073/pnas.0913714108

Lewin, B., Giovannucci, D., \& Varangis, P. (2004). Coffee markets: new paradigms in global supply and demand. World Bank Agriculture and Rural Development Discussion Paper (3).

Liu, P. (2003). Environmental and social standards, certification and labelling for cash crops (Vol. 2): Food \& Agriculture Org.

Loconto, A., \& Dankers, C. (2014). Impact of international voluntary standards on smallholder market participation in developing countries. FAO. Retrieved on June 14, 2015 from http://www.fao.org/3/a-i3682e.pdf. 
Lyngbaek, A. E., Muschler, R.G., \& Sinclair, F.L. (2001). Productivity and profitability of multistrata organic versus conventional coffee farms in Costa Rica. Agroforestry Systems 53: 205-213. doi: 10.1023/A:1013332722014.

M4P. (2008). Making Value Chains Work Better for the Poor: A Toolbook for Practitioners of Value Chain Analysis, Version 3. Making Markets Work Better for the Poor (M4P) Project, UK Department for International Development (DFID). Agricultural Development International: Phnom Penh, Cambodia.

Mackenzie, J. (1993). A Comparison of Contingent Preference Models. American Journal of Agricultural Economics, 75(3), 593-603. doi: 10.2307/1243566.

Maertens, M., \& Swinnen, J. F. M. (2009). Trade, Standards, and Poverty: Evidence from Senegal. World Development, 37(1), 161-178. doi: 10.1016/j.worlddev.2008.04.006.

Malaysian Legislation. (1972). Rubber Industry Smallholders Development Authority Act 1972. Retrieved January 21, 2017 from http://www.commonlii.org/my/legis/consol_act/risdaa1972577/.

Malaysian Palm Oil Board (MPOB). (2005). Malaysian Palm Oil Board (Licensing) Regulations 1979 [P.U.(A)33/79]. Retrieved January 21, 2017 from http://www.mpob.gov.my/en/licensing-a-enforcement/law-a-legislation/511achieevements.

Manning, S., Boons, F., Von Hagen, O., \& Reinecke, J. (2012). National contexts matter: The co-evolution of sustainability standards in global value chains. Ecological Economics, 83, 197-209. doi: 10.1016/j.ecolecon.2011.08.029.

Marchenko, Y. V., \& Genton, M. G. (2012). A Heckman selection-t model. Journal of the American Statistical Association, 107(497), 304-317. Doi: 10.1080/01621459.2012.656011.

Markelova, H., Meinzen-Dick, R., Hellin, J., \& Dohrn, S. (2009). Collective action for smallholder market access. Food Policy, 34(1), 1-7. doi: 10.1016/j.foodpol.2008.10.001.

Mausch, K., Mithöfer, D., Asfaw, S., \& Waibel, H. (2009). Export Vegetable Production in Kenya under the EurepGAP Standard: Is Large "More Beautiful" than Small? Journal of Food Distribution Research, 40(3), 115-129. Retrieved April18, 2014, from http://core.ac.uk/download/pdf/6678323.pdf.

Mawardi, S. 2014. Developing a Road Map for the Coffee Sector in Indonesia: Positioning Strategy of the Indonesia Specialty Coffee Industry on Global Value Chain. Paper presented at the Roundtable Workshop organized by the Ministry of Trade of the Republic Indonesia and the Word Bank, Jakarta, February 4, 2014.

Media Perkebunan. (2013). Indonesian Standart Coffee Segera Diterapkan. Retrieved April 24, 2014, from http://www.mediaperkebunan.net/index.php?option=com_contentandview=a rticleandid=637: indonesian-sta ndart-coffee-segeraditerapkanandcatid $=2$ : komoditiandltemid $=26$.

Méndez, V. E., Bacon, C. M., Olson, M., Petchers, S., Herrador, D., Carranza, C., ... \& Mendoza, A. (2010). Effects of Fair Trade and organic certifications on smallscale coffee farmer households in Central America and Mexico. Renewable 


\section{References}

Agriculture and Food Systems, 25(03), 236-251. doi: 10.1017/S1742170510000268.

Milder, J. C., Arbuthnot, M., Blackman, A., Brooks, S. E., Giovannucci, D., Gross, L., . . . Lee, A. (2015). An agenda for assessing and improving conservation impacts of sustainability standards in tropical agriculture. Conservation biology, 29(2), 309-320. doi: 10.1111/cobi.12411.

Molenaar, J. W., Kessler, J. J., Blackmore, E., Vorley, B., Gorter, J., \& Simons, L. (2013). Building a roadmap to sustainability in agro-commodity production. Aidenvironment, NewForesight, IIED.

Moses, J., \& Knutsen, T. (2012). Ways of knowing: Competing methodologies in social and political research. Palgrave Macmillan.

Mujawamariya, G., D'Haese, M., \& Speelman, S. (2013). Exploring double side-selling in cooperatives, case study of four coffee cooperatives in Rwanda. Food Policy 39: 72-83. doi: 10.1016/j.foodpol.2012.12.008.

Muradian, R., \& Pelupessy, W. (2005). Governing the coffee chain: The role of voluntary regulatory Systems. World Development, 33(12), 2029-2044. doi: 10.1016/j.worlddev.2005.06.007.

Murisa, T. (2011). Local farmer groups and collective action within fast track land reform in Zimbabwe. The Journal of Peasant Studies, 38(5), 1145-1166. doi: 10.1080/03066150.2011.634502.

Narrod, C., Roy, D., Okello, J., Avendaño, B., Rich, K., \& Thorat, A. (2009). Public-private partnerships and collective action in high value fruit and vegetable supply chains. Food Policy, 34(1), 8-15. doi: 10.1016/j.foodpol.2008.10.005.

Neilson, J. (2008). Global Private Regulation and Value-Chain Restructuring in Indonesian Smallholder Coffee Systems. World Development, 36(9), 16071622. doi: 10.1016/j.worlddev.2007.09.005.

Neilson, J. (2014). Developing a Road Map for the Coffee Sector in Indonesia: Situation Analysis and Options for Value Chain Upgrading and Raising Incomes. Paper presented at the Roundtable Workshop (04 February 2014) organized by the Ministry of Trade of the Republic Indonesia and the Word Bank, Jakarta.

Neilson, J., \& Pritchard, B. (2011). Value chain struggles: Institutions and governance in the plantation districts of South India (Vol. 93): John Wiley \& Sons.

Nuva, Y, N.K. Hidayat, \& Hanna. (2013). Impact of Eco-Labelling on Indonesia's Smallholder Coffee Farmers. Philippines: WorldFish (ICLARM). Retrieved on April 21, 2105 from http://www.eepsea.net/pub/rr/2013-RR9_Nuva.pdf.

Palis, F. G. (2006). The role of culture in farmer learning and technology adoption: a case study of farmer field schools among rice farmers in central Luzon, Philippines. Agriculture and Human Values, 23(4), 491-500. doi: 10.1007/s10460-006-9012-6.

Parrish, B. D., Luzadis, V. A., \& Bentley, W. R. (2005). What Tanzania's coffee farmers can teach the world: a performance-based look at the fair trade-free trade debate. Sustainable Development, 13(3), 177-189. doi: 10.1002/sd.276.

Patterson, J., Schulz, K., Vervoort, J., van der Hel, S., Widerberg, O., Adler, C., . . . Barau, A. (2016). Exploring the governance and politics of transformations towards 
sustainability. Environmental Innovation and Societal Transitions. doi: 10.1016/j.eist.2016.09.001.

Perkebunannews. (2016). Pasar ekspor kopi membesar local eksportir mengecil. Retrieved December 10, 2016 from http://perkebunannews.com/2016/03/11/pasar-ekspor-kopi-membesareksportir-lokal-mengecil/.

Permentan RI No. 49. (2014). Peraturan menteri pertanian Republik Indonesia No.49/Permentan/OT.140/4/2014 tentang pedoman teknis budidaya kopi yang baik. Jakarta, Indonesia.

Permentan RI No. 82. (2013). Peraturan menteri pertanian Republik Indonesia nomor 82/Permentan/OT.140/8/2013 tentang pedoman pembinaan kelompoktani dan gabungan kelompoktani. Jakarta, Indonesia.

Perpres RI No. 45. (2015). Peraturan Presiden Republik Indonesia tentang kementerian pertanian. Jakarta, Indonesia.

Philpott, S. M., Bichier, P., Rice, R., \& Greenberg, R. (2007). Field-testing ecological and economic benefits of coffee certification programs. Conservation Biology, 21(4), 975-985. doi: 10.1111/j.1523-1739.2007.00728.x.

Pierrot, J., Giovannucci, D., Kasterine, A. (2010). Trends in the Trade of Certified Coffees. International Trade Centre: Geneva.

Pinto, L. F. G., Gardner, T., McDermott, C. L., \& Ayub, K. O. L. (2014). Group certification supports an increase in the diversity of sustainable agriculture networkrainforest alliance certified coffee producers in Brazil. Ecological Economics, 107, 59-64. doi: 10.1016/j.ecolecon.2014.08.006

Place, F., Kariuki, G., Wangila, J., Kristjanson, P., Makauki, A., \& Ndubi, J. (2004). Assessing the factors underlying differences in achievements of farmer groups: methodological issues and empirical findings from the highlands of Central Kenya. Agricultural Systems, 82(3), 257-272. doi: 10.1016/j.agsy.2004.07.001.

Ponte, S. (2002). The 'Latte Revolution'? Regulation, Markets and Consumption in the Global Coffee Chain. World Development, 30(7), 1099-1122. doi: http://dx.doi.org/10.1016/S0305-750x(02)00032-3

Ponte, S. (2004). Standards and Sustainability in the Coffee Sector: A Global Value Chain Approach. United Nations Conference on Trade and Development and the International Institute for Sustainable Development.

Porter, M. E. (2000). Location, competition, and economic development: Local clusters in a global economy. Economic development quarterly, 14(1), 15-34.

Potts, J., Von Moltke, K., Taporaie, A., \& Arda, M. (2003). Sustainability in the coffee sector: Exploring opportunities for international cooperation. IISD, UNCTAD. Retrieved January 21, 2013 from http://www.iisd.org/pdf/2003/sci_coffee_background.pdf.

PP RI No. 102. (2000). Peraturan pemerintah Republik Indonesia tentang standardisasi nasional. Jakarta, Indonesia.

PP RI No. 42. (1981). Peraturan Pemerintah Republik Indonesia nomor 42 tahun 1981 tentang Pelayanan kesejahteraan social bagi fakir miskin. Jakarta, Indonesia

RA. (2017). Protecting against modern slavery in agricultural supply chains through SAN/Rainforest Alliance certification. Retrieved February 25, 2017 from 


\section{References}

http://www.rainforest-alliance.org/sites/default/files/2017-04/protectingagainst-modern-slavery.pdf

RA. (2017). Sustainable agriculture standard. Retrieved June 21, 2017 from https://dl.dropboxusercontent.com/u/585326/2017SAN/Certification\%20Docu ments/SAN-Standard-2017.pdf.

Raghavarao, D., J. B. Wiley, and P. Chitturi. 2011. Choice-Based Conjoint Analysis: Models and Designs (1st ed.). Boca Raton: Taylor and Francis Group, LLC. USA. Retrieved July 10, 2013 from http://doww.ru/docs/5/4046/conv 1/file1.pdf.

Raynolds, L. T., Murray, D., \& Heller, A. (2007). Regulating sustainability in the coffee sector: A comparative analysis of third-party environmental and social certification initiatives. Agriculture and Human Values, 24(2), 147-163. doi: 10.1007/s10460-006-9047-8.

Raynolds, L. T., Murray, D., \& Leigh Taylor, P. (2004). Fair trade coffee: building producer capacity via global networks. Journal of International Development, 16(8), 1109-1121. doi: 10.1002/jid.1136.

Reardon, T., Codron, J.-M., Busch, L., Bingen, J., \& Harris, C. (1999). Global change in agrifood grades and standards: agribusiness strategic responses in developing countries. The International Food and Agribusiness Management Review, 2(34), 421-435. doi: http://dx.doi.org/10.1016/S1096-7508(01)00035-0.

Reinecke, J., Manning, S., \& Von Hagen, O. (2012). The emergence of a standards market: Multiplicity of sustainability standards in the global coffee industry. Organization Studies, 33(5-6), 791-814. doi: 10.1177/0170840612443629.

Reis, H. J., \& Silva, J. S. (2006). Hedonic prices indexes for new passenger cars in Portugal (1997-2001). Economic Modelling, 23(6), 890-908. doi: 10.1016/j.econmod.2006.04.003.

Ruben, R., \& Fort, R. (2012). The Impact of Fair Trade Certification for Coffee Farmers in Peru. World Development, 40(3), 570-582. doi: 10.1016/j.worlddev.2011.07.030.

Ruben, R., \& Zuniga, G. (2011). How standards compete: comparative impact of coffee certification schemes in Northern Nicaragua. Supply Chain Management: An International Journal, 16(2), 98-109. doi: 10.1108/13598541111115356.

Rueda, X., \& Lambin, E. F. (2013). Responding to Globalization: Impacts of Certification on Colombian Small-Scale Coffee Growers. Ecology and Society, 18(3), 215227. doi: Unsp 21Doi 10.5751/Es-05595-180321.

Salami, A., Kamara, A. B., \& Brixiova, Z. (2010). Smallholder agriculture in East Africa: Trends, constraints and opportunities: African Development Bank Tunis.

Sapsford, R., \& Jupp, V. (2006). Data collection and analysis. Sage publication in association with the Open University.

Schouten, G., \& Bitzer, V. (2015). The emergence of Southern standards in agricultural value chains: A new trend in sustainability governance? Ecological Economics, 120, 175-184. doi: 10.1016/j.ecolecon.2015.10.017.

SCP. (2014). Indonesia a business case for sustainable coffee production. Sustainable coffee program (SCP). Retrieved on May 24. 2015 from http://www.sustainablecoffeeprogram.com/en/resources 
Setiawan, A., Cinner, J. E., Sutton, S. G., \& Mukminin, A. (2012). The perceived impact of customary marine resource management on household and community welfare in northern Sumatra, Indonesia. Coastal Management, 40(3), 239-249. doi: 10.1080/08920753.2012.677626.

Sherrick, B. J., Barry, P. J., Ellinger, P. N., \& Schnitkey, G. D. (2004). Factors influencing farmers' crop insurance decisions. American Journal of Agricultural Economics, 86(1), 103-114. doi: 10.1111/j.0092-5853.2004.00565.x.

Slob, B. (2006). A fair share for smallholders. A Value Chain Analysis of the Coffee Sector. Centre for Research of Multinational Corporations (SOMO). Retrieved on June 19, $2015 \quad$ from http://www.valuechains.org/dyn/bds/docs/623/SOMO\%20MA\%20of\%20Intl\%20Coffee\%20Mkt \%2006.pdf.

Smit, A. A. H., Driessen, P. P. J., \& Glasbergen, P. (2008). Constraints on the conversion to sustainable production: the case of the Dutch potato chain. Business Strategy and the Environment, 17(6), 369-381. doi: 10.1002/bse.554. doi:10.1002/bse.554.

Smith, T. M., \& Fischlein, M. (2010). Rival private governance networks: Competing to define the rules of sustainability performance. Global Environmental Change, 20(3), 511-522. doi:10.1016/j.gloenvcha.2010.03.006.

Somda, J., Nianogo, A. J., Nassa, S., \& Sanou, S. (2002). Soil fertility management and socio-economic factors in crop-livestock systems in Burkina Faso: a case study of composting technology. Ecological economics,43(2), 175-183. doi: 10.1016/S0921-8009(02)00208-2.

Stapel, K., \& Schneider, K. (2012). Managing knowledge on communication and information flow in global software projects. Expert Systems, n/a-n/a. doi: 10.1111/j.1468-0394.2012.00649.x.

Sudibyo, B. (2012). Reformasi Pajak Dalam Kerangka Reformasi Ekonomi-Politik di Indonesia. Jurnal Akuntansi \& Manajemen (JAM), 87.

Sugandhi, H. (2014). Developing a Road Map for the Coffee Sector in Indonesia: Potensi, Hambatan dan Strategi Pengembangan Kopi Indonesia. Paper presented at the Roundtable Workshop organized by the Ministry of Trade of the Republic Indonesia and the Word Bank, Jakarta, February 4, 2014.

Suradi. (2012). Pendekatan Kelompok sebagai modalitas dalam penanggulangan kemiskinan. Jurnal Pusat Penelitian dan Pengembangan Kesejahteraan Sosial Kementerian Sosial Republik Indonesia. Accessed November 2015, 20 from http://puslit.kemsos.go.id/upload/post/files/2d197badf554aba1dfc58ed23781 be80.pdf.

StataCorp. 2013. Stata: Release 13. Statistical Software. College Station, TX: StataCorp LP.

Tabloidsinartani. (2014). Standar perkebunan kopi berkelanjutan Indonesia. Retrieved December $\quad 02, \quad 2016 \quad$ from http://m.tabloidsinartani.com/index.php?id=148\&tx_ttnews\%5Btt_news\%5D= 1358\&cHash=86b06eda97e29a463d93462fe67258a6.

Tabloidsinartani. (2016). Kementan Luncurkan Kurikulum Nasional Pelatihan Kopi Robusta untuk Petani. Retrieved February 18, 2017 from 


\section{References}

http://tabloidsinartani.com/content/read/kementan-luncurkan-kurikulumnasional-pelatihan-kopi-Robusta-untuk-petani/.

Tabloidsinartani. (2016). Postur penyuluhan pertanian pada era uu pemerintahan daerah. Retrieved January 12, 2017 from http://tabloidsinartani.com/content/read/postur-penyuluhan-pertanian-padaera-uu-pemerintahan-daerah-2014/.

Tallontire, A. (2007). CSR and Regulation: Towards a Framework for Understanding Private Standards Initiatives in the Agri-Food Chain. Third World Quarterly, 28(4), 775-791. Retrieved July 202014 from http://www.jstor.org/stable/20454961.

Tano, K., Kamuanga, M., Faminow, M. D., \& Swallow, B. (2003). Using conjoint analysis to estimate farmer's preferences for cattle traits in West Africa. Ecological Economics, 45(3), 393-407. doi: 10.1016/S0921-8009(03)00093-4.

Taylor, P. L., Murray, D. L., \& Raynolds, L. T. (2005). Keeping trade fair: governance challenges in the fair trade coffee initiative. Sustainable Development, 13(3), 199-208. doi: 10.1002/sd.278.

TCC. (2012). Coffee Barometer 2012. Retrieved July 18, 2013 from http://www.teacoffeecocoa.org/tcc/Publications/Our-publications.

The Directorate General of Estate Crops of Indonesia. (2013). Prinsip dan kriteria standar kopi berkelanjutan Indonesia (ISCoffee). Makalah pelatihan ISCoffee in Sumber Rejo Tanggamus, Lampung. Unpublished.

The Directorate General of Estate Crops of Indonesia. (2014). Satistik Perkebunan Kopi Indonesia. Jakarta, Indonesia. Retrieved January 18, 2016 from http://ditjenbun.pertanian.go.id/tinymcpuk/gambar/file/statistik/2015/KOPI\% 202013\%20-2015.pdf.

The Directorate General of Estate Crops of Indonesia. (2015). Rencana strategis Direktorat Jenderal Perkebunan tahun 2015-2019. Retrieved November 01, 2015 from http://ditjenbun.pertanian.go.id/tinymcpuk/gambar/file/infopublik/Rentra\%20Ditjenbun\%202015-2019.pdf.

The government of India \& UNDP. (2004). Integrated Land and Ecosystem Management to Combat Land Degradation and Deforestation in Madhya Pradesh. The Government of India and Global Environment Facility of United Nations Development Programme. Project Document (PIMS 3512). December 2004. Retrieved January 21, 2017 from http://mwh.mpforest.org/UNDP/document.pdf.

The Ministry of Agriculture of Indonesia (2016). Outlook kopi tahun 2016. Pusat Data dan Sistem Informasi Pertanian. Kementerian Pertanian Republik Indonesia. Jakarta, Indonesia.

The Ministry of Agriculture of Indonesia. (2006). Peraturan menteri pertanian nomor 33/Permentan/OT.140/7/2006 tentang pengembagan perkebunan melalui revitalisasi perkebunan. Retrieved from http://perundangan.pertanian.go.id/admin/file/Permentan-33-06.pdf, 18 May 2016.

The Ministry of Agriculture of Indonesia. (2015). Pelatihan fasilitatsi/rintisan penerapan perkebunan kopi berlanjutan. Retrieved June 18, 2015, from 
http://cybex.pertanian.go.id/materilokalita/detail/11984/pelatihanfasilitasirintisan-penerapan-perkebunan-kopi-berkelanjutan-iscoffee-kelompok-tanisentra-kopi-kec-sembalun.

The Ministry of Environment and Forestry of Indonesia (2016). Penetapan areal kerja hutan kemasyarakatan (HKM). Retrieved May 21, 2017 from http://www.menlhk.go.id/tinymcpuk/gambar/file/7.\%20RINCIAN\%20PAK\%20H KM\%20TH\%202016.pdf.

The World Bank. (2003). Reaching the rural poor: A renewed strategy for rural development. Retrieved January 21, 2015 from http://documents.worldbank.org/curated/en/227421468165890144/pdf/2676 3OREACHINGOTHEORURALOPOORO.pdf.

Thorp, R., Stewart, F., \& Heyer, A. (2005). When and how far is group formation a route out of chronic poverty? World Development, 33(6), 907-920. doi: 10.1016/j.worlddev.2004.09.016.

Thow, A. M., Snowdon, W., Labonté, R., Gleeson, D., Stuckler, D., Hattersley, L., . . Friel, S. (2015). Will the next generation of preferential trade and investment agreements undermine prevention of noncommunicable diseases? A prospective policy analysis of the Trans Pacific Partnership Agreement. Health Policy, 119(1), 88-96. doi: 10.1016/j.healthpol.2014.08.002.

Utting, K. (2009). Assessing the Impact of Fair Trade Coffee: Towards an Integrative Framework. Journal of Business Ethics, 86(S1), 127-149. doi: 10.1007/s10551008-9761-9.

Utting-chamorro, K. (2005). Does fair trade make a difference? The case of small coffee producers in Nicaragua. Development in Practice, 15(3-4), 584-599. doi: 10.1080/09614520500075706.

UTZ. (2017). The UTZ standard. Retrieved February 21, 2017 from https://UTZ.org/what-we-offer/certification/the-standard/.

UTZ. (2015). Core code of conduct for group and multi-group certification. Retrieved June 21, 2017 from https://utz.org/wpcontent/uploads/2015/12/EN_UTZ_Core-Code-Group_v1.1_2015.pdf.

UU RI No. 15 (2001). Undang-undang Republik Indonesia nomor 15 tahun 2001 tentang merek. Jakarta, Indonesia.

UU RI No. 16 (2006). Undang-undang Republik Indonesia Nomor 16 tahun 2006 tentang sistem penyuluhan pertanian, perikanan, dan kehutanan. Jakarta, Indonesia.

UU RI No. 20. (2008). Undang-undang Republik Indonesia nomor 20 tahun 2008 tentang usaha mikro, kecil, dan menengah. Jakarta, Indonesia.

UU RI No. 25. (1992). Undang-undang Republik Indonesia nomor 25 tahun 1992 tentang perkoperasian. Jakarta, Indonesia.

UU RI No. 30. (2002). Undang Undang Republik Indonesia Nomor 30 tentang Komisi Pemberantasan Tindak Pidana Korupsi. Jakarta, Indonesia.

UU RI No. 39. (2014). Undang-undang Republik Indonesia Nomor 30 tentang perkebunan. Jakarta, Indonesia

Valkila, J. (2009). Fair Trade organic coffee production in Nicaragua: Sustainable development or a poverty trap? Ecological Economics 68: 3018-25. doi: 10.1016/j.ecolecon.2009.07.002. 


\section{References}

Valkila, J., \& Nygren, A. (2010). Impacts of Fair Trade certification on coffee farmers, cooperatives, and laborers in Nicaragua. Agriculture and Human Values, 27(3), 321-333. doi: 10.1007/s10460-009-9208-7.

Van der Vossen, H. (2005). A critical analysis of the agronomic and economic sustainability of organic coffee production. Experimental agriculture, 41(04), 449-473. doi: 10.1017/S0014479705002863.

Van Rijsbergen, B., Elbers, W., Ruben, R., \& Njuguna, S. N. (2016). The Ambivalent Impact of Coffee Certification on Farmers' Welfare: A Matched Panel Approach for Cooperatives in Central Kenya. World Development, 77, 277-292. doi: 10.1016/j.worlddev.2015.08.021.

Van Tulder, R., Muller, A., \& de Boer, D. (2004). Partnerships, Power And Equity In Global Commodity Chains: Position paper on cooperation between companies and NGOs in stimulating sustainable development. Expert centre for sustainable business and development cooperation (ECSAD).

Vellema, S., van Wijk, J., Drost, S., Douma, M., \& de Roo, N. (2012). Looking beyond upgrading; how value-chain partnerships create institutional change. 19th Annual Conference on Multi-Organisational Partnerships, Alliances and Networks, 2-4 July 2012, Wageningen University.

Vermeulen, W. J., \& Hovens, J. (2006). Competing explanations for adopting energy innovations for new office buildings. Energy Policy, 34(17), 2719-2735. doi:10.1016/j.enpol.2005.04.009.

Wahyudi, T. and M. Jati. (2012). Challenges of Sustainable Coffee Certification in Indonesia. Paper presented at the seminar on the Economic, Social and Environmental Impact of Certification on the Coffee Supply Chain, International Coffee Council 109th Session, London, United Kingdom 25th September 2012. Retrieved July 18, 2013, from http://www.ico.org/event_pdfs/seminar-certification/certification-iccripaper.pdf.

Walley, K., Parsons, S., and Bland, M. (1999). Quality assurance and the consumer: a conjoint study. British Food Journal, 101(2), 148-162. doi: 10.1108/00070709910261936.

Weber, J. (2007). Fair Trade Coffee Enthusiasts Should Confront Reality. Cato Journal 27(1), 109-118. Retrieved January 21, 2015 from http://heinonline.org/HOL/Page?handle=hein.journals/catoj27\&div=12\&g_sen $\mathrm{t}=1$ \&collection=journals.

Weiner, J. (1994). Consumer electronics marketer uses a conjoint approach to configure its new product and set the right price. (cover story). Marketing Research, 6(3), 6-11. Retrieved January 19, 2014 from http://web.a.ebscohost.com/ehost/pdfviewer/pdfviewer?sid=b4c7849d-4fbe41c1-80ee-f35d71867711\%40sessionmgr4007\&vid=0\&hid=4114.

Wheeler, S. A. (2008). What influences agricultural professionals' views towards organic agriculture? Ecological Economics, 65(1), 145-154. doi: 10.1016/j.ecolecon.2007.05.014.

Wiggins, S., Kirsten, J., \& Llambí, L. (2010). The future of small farms. World Development, 38(10), 1341-1348. doi: 10.1016/j.worlddev.2009.06.013. 
Wijaya, A., \& Glasbergen, P. (2016). Toward a new scenario in agricultural sustainability certification? The Response of the Indonesian national government to private certification. The Journal of Environment \& Development, 25(2), 219-246. doi: 10.1177/1070496516640857. 


\section{Appendix 1}

Appendix 1. Display of full profiles (orthogonal design)

\begin{tabular}{|c|c|c|c|c|c|c|c|c|c|}
\hline $\begin{array}{l}\text { Card } \\
\text { ID }\end{array}$ & $\begin{array}{l}\text { Price } \\
\text { Premium }\end{array}$ & $\begin{array}{l}\text { Certification } \\
\text { Target }\end{array}$ & $\begin{array}{l}\text { Environmental } \\
\text { Focus }\end{array}$ & $\begin{array}{l}\text { Important } \\
\text { goal }\end{array}$ & $\begin{array}{l}\text { Credit } \\
\text { Option }\end{array}$ & $\begin{array}{l}\text { Marketing } \\
\text { Schemes }\end{array}$ & $\begin{array}{l}\text { Differential } \\
\text { Price } \\
\text { Based on } \\
\text { Size Coffee } \\
\text { Bean size }\end{array}$ & $\begin{array}{l}\text { Differential } \\
\text { Price with } \\
\text { Noncertified } \\
\text { Farmers }\end{array}$ & $\begin{array}{l}\text { Rating } \\
(1-5)\end{array}$ \\
\hline 1 & Yes & $\begin{array}{l}\text { Smallholder } \\
\text { farmers in } \\
\text { group or } \\
\text { cooperative }\end{array}$ & Conservation & Fairness & $\begin{array}{l}\text { Pre- } \\
\text { finance }\end{array}$ & $\begin{array}{l}\text { Contract } \\
\text { between } \\
\text { seller and } \\
\text { buyer }\end{array}$ & Yes & Yes & \\
\hline 2 & No & $\begin{array}{l}\text { Large } \\
\text { Estates }\end{array}$ & $\begin{array}{l}\text { Biodiversity, } \\
\text { soil fertility, } \\
\text { agro-ecology }\end{array}$ & Sustainability & $\begin{array}{l}\text { Pre- } \\
\text { finance }\end{array}$ & $\begin{array}{l}\text { No } \\
\text { Contract }\end{array}$ & Yes & Yes & \\
\hline 3 & Yes & $\begin{array}{l}\text { Smallholder } \\
\text { farmers in } \\
\text { group or } \\
\text { cooperative }\end{array}$ & Conservation & Fairness & $\begin{array}{l}\text { Pre- } \\
\text { finance }\end{array}$ & $\begin{array}{l}\text { No } \\
\text { Contract }\end{array}$ & No & No & \\
\hline 4 & No & $\begin{array}{l}\text { Large } \\
\text { Estates }\end{array}$ & Conservation & Fairness & $\begin{array}{l}\text { No } \\
\text { Credit }\end{array}$ & $\begin{array}{l}\text { Contract } \\
\text { between } \\
\text { seller and } \\
\text { buyer }\end{array}$ & No & Yes & \\
\hline 5 & No & $\begin{array}{l}\text { Smallholder } \\
\text { farmers in } \\
\text { group or } \\
\text { cooperative }\end{array}$ & Conservation & Sustainability & $\begin{array}{l}\text { No } \\
\text { Credit }\end{array}$ & $\begin{array}{l}\text { Contract } \\
\text { between } \\
\text { seller and } \\
\text { buyer }\end{array}$ & No & Yes & \\
\hline 6 & Yes & $\begin{array}{l}\text { Smallholder } \\
\text { farmers in } \\
\text { group or } \\
\text { cooperative }\end{array}$ & Organic & Sustainability & $\begin{array}{l}\text { No } \\
\text { Credit }\end{array}$ & $\begin{array}{l}\text { Contract } \\
\text { between } \\
\text { seller and } \\
\text { buyer }\end{array}$ & Yes & No & \\
\hline 7 & Yes & $\begin{array}{l}\text { Large } \\
\text { Estates }\end{array}$ & Conservation & Sustainability & $\begin{array}{l}\text { Pre- } \\
\text { finance }\end{array}$ & $\begin{array}{l}\text { No } \\
\text { Contract }\end{array}$ & No & No & \\
\hline 8 & No & $\begin{array}{l}\text { Large } \\
\text { Estates }\end{array}$ & Conservation & Fairness & $\begin{array}{l}\text { No } \\
\text { Credit }\end{array}$ & $\begin{array}{l}\text { No } \\
\text { Contract }\end{array}$ & Yes & No & \\
\hline 9 & No & $\begin{array}{l}\text { Smallholder } \\
\text { farmers in } \\
\text { group or } \\
\text { cooperative }\end{array}$ & Conservation & Sustainability & $\begin{array}{l}\text { No } \\
\text { Credit }\end{array}$ & $\begin{array}{l}\text { No } \\
\text { Contract }\end{array}$ & Yes & No & \\
\hline 10 & Yes & $\begin{array}{l}\text { Smallholder } \\
\text { farmers in } \\
\text { group or } \\
\text { cooperative }\end{array}$ & $\begin{array}{l}\text { Biodiversity, } \\
\text { soil fertility, } \\
\text { agro-ecology }\end{array}$ & Sustainability & $\begin{array}{l}\text { No } \\
\text { Credit }\end{array}$ & $\begin{array}{l}\text { No } \\
\text { Contract }\end{array}$ & No & Yes & \\
\hline 11 & No & $\begin{array}{l}\text { Large } \\
\text { Estates }\end{array}$ & Organic & Sustainability & $\begin{array}{l}\text { Pre- } \\
\text { finance }\end{array}$ & $\begin{array}{l}\text { Contract } \\
\text { between } \\
\text { seller and } \\
\text { buyer }\end{array}$ & No & No & \\
\hline 12 & Yes & $\begin{array}{l}\text { Large } \\
\text { Estates }\end{array}$ & Conservation & Sustainability & $\begin{array}{l}\text { Pre- } \\
\text { finance }\end{array}$ & $\begin{array}{l}\text { Contract } \\
\text { between } \\
\text { seller and } \\
\text { buyer }\end{array}$ & Yes & Yes & \\
\hline 13 & No & $\begin{array}{l}\text { Smallholder } \\
\text { farmers in } \\
\text { group or } \\
\text { cooperative }\end{array}$ & Organic & Fairness & $\begin{array}{l}\text { Pre- } \\
\text { finance }\end{array}$ & $\begin{array}{l}\text { No } \\
\text { Contract }\end{array}$ & Yes & Yes & \\
\hline 14 & No & $\begin{array}{l}\text { Smallholder } \\
\text { farmers in } \\
\text { group or } \\
\text { cooperative }\end{array}$ & $\begin{array}{l}\text { Biodiversity, } \\
\text { soil fertility, } \\
\text { agro-ecology }\end{array}$ & Fairness & $\begin{array}{l}\text { Pre- } \\
\text { finance }\end{array}$ & $\begin{array}{l}\text { Contract } \\
\text { between } \\
\text { seller and } \\
\text { buyer }\end{array}$ & No & No & \\
\hline
\end{tabular}


Appendix 1

\begin{tabular}{|c|c|c|c|c|c|c|c|c|}
\hline 15 & Yes & $\begin{array}{l}\text { Large } \\
\text { Estates }\end{array}$ & $\begin{array}{l}\text { Biodiversity, } \\
\text { soil fertility, } \\
\text { agro-ecology }\end{array}$ & Fairness & $\begin{array}{l}\text { No } \\
\text { Credit }\end{array}$ & $\begin{array}{l}\text { Contract } \\
\text { between } \\
\text { seller and } \\
\text { buyer }\end{array}$ & Yes & No \\
\hline 16 & Yes & $\begin{array}{l}\text { Large } \\
\text { Estates }\end{array}$ & Organic & Fairness & $\begin{array}{l}\text { No } \\
\text { Credit }\end{array}$ & $\begin{array}{l}\text { No } \\
\text { Contract }\end{array}$ & No & Yes \\
\hline
\end{tabular}




\section{Appendix 2}

Appendix 2. Preliminary list of attributes and levels of certification programs

\begin{tabular}{|c|c|c|c|c|c|}
\hline & \multirow{2}{*}{ Attributes } & \multicolumn{4}{|c|}{ Attribute Levels } \\
\hline & & 1 & 2 & 3 & 4 \\
\hline 1. & $\begin{array}{l}\text { Certification } \\
\text { Target }\end{array}$ & All Producers & $\begin{array}{l}\text { High quality coffee } \\
\text { grower only }\end{array}$ & $\begin{array}{l}\text { Smallholder } \\
\text { Farmer in } \\
\text { groups or } \\
\text { cooperatives }\end{array}$ & $\begin{array}{l}\text { Large } \\
\text { estates }\end{array}$ \\
\hline 2. & $\begin{array}{l}\text { Community } \\
\text { outreach }\end{array}$ & $\begin{array}{l}\text { Premium use for } \\
\text { community } \\
\text { programs }\end{array}$ & $\begin{array}{l}\text { Linkages with input } \\
\text { suppliers and laborer }\end{array}$ & $\begin{array}{l}\text { Project in coffee } \\
\text { communities }\end{array}$ & \\
\hline 3. & Credit & Pre-finance & Through (Local) banks & $\begin{array}{l}\text { Farmer Loan } \\
\text { Fund }\end{array}$ & \\
\hline 4. & $\begin{array}{l}\text { Environmental } \\
\text { Focus }\end{array}$ & $\begin{array}{l}\text { Close to } \\
\text { environmental } \\
\text { conservation }\end{array}$ & $\begin{array}{l}\text { Biodiversity, soil fertility, } \\
\text { agro-ecology }\end{array}$ & $\begin{array}{l}\text { Close to organic } \\
\text { input }\end{array}$ & $\begin{array}{l}\text { Soil } \\
\text { fertility, } \\
\text { erosion } \\
\text { resilience }\end{array}$ \\
\hline 5. & $\begin{array}{l}\text { Inspection } \\
\text { Frequency and } \\
\text { accreditation }\end{array}$ & Annually & At least annual & Every 3 years & \\
\hline 6. & Key aspects & $\begin{array}{l}\text { Labor, livelihood } \\
\text { and participation }\end{array}$ & $\begin{array}{l}\text { Sustainable resource } \\
\text { management practice }\end{array}$ & $\begin{array}{l}\text { Production and } \\
\text { quality } \\
\text { management }\end{array}$ & \\
\hline 7. & Labor input & Higher & Moderate & & \\
\hline 8. & Main Focus & Fairness & Sustainability & $\begin{array}{l}\text { Responsible } \\
\text { sourcing }\end{array}$ & \\
\hline 9. & Market Focus & All Market & Mainstream & Niche, Specialty & \\
\hline 10. & $\begin{array}{l}\text { Marketing } \\
\text { schemes }\end{array}$ & $\begin{array}{l}\text { Contract between } \\
\text { producers and } \\
\text { buyers }\end{array}$ & No contract & & \\
\hline 11. & $\begin{array}{l}\text { Price Differential } \\
\text { to Farmers }\end{array}$ & $\begin{array}{l}\text { Negotiated } \\
\text { between seller and } \\
\text { buyer }\end{array}$ & Set by the program & Set by market & \\
\hline 12. & Price Premium & $\begin{array}{l}\text { Yes (minimum } \\
\text { floor price/ market } \\
\text { price +price } \\
\text { premium) }\end{array}$ & $\begin{array}{l}\text { No, but market price } \\
\text { (Farmers earn more } \\
\text { through gains in } \\
\text { efficiency, improved } \\
\text { quality and controlling } \\
\text { farm costs). }\end{array}$ & $\begin{array}{l}\text { No, but } \\
\text { negotiated } \\
\text { between seller } \\
\text { and buyer }\end{array}$ & \\
\hline 13. & Scope of Program & $\begin{array}{l}\text { All aspects: Social, } \\
\text { Economic, and } \\
\text { Environmental }\end{array}$ & $\begin{array}{l}\text { Only two aspects (e.g. } \\
\text { social-economic) }\end{array}$ & $\begin{array}{l}\text { Only one aspect } \\
\text { (e.g. economic) }\end{array}$ & \\
\hline 14. & Standards & $\begin{array}{l}\text { Minimum and } \\
\text { progress standard }\end{array}$ & $\begin{array}{l}\text { Minimum compliance } \\
\text { standard }\end{array}$ & $\begin{array}{l}\text { Scorecard with } \\
\text { indicators }\end{array}$ & \\
\hline 15. & $\begin{array}{l}\text { Supply chain } \\
\text { coverage }\end{array}$ & $\begin{array}{l}\text { Supply chain } \\
\text { record }\end{array}$ & $\begin{array}{l}\text { Chain of custody } \\
\text { requirements }\end{array}$ & $\begin{array}{l}\text { Supply chain } \\
\text { traceability }\end{array}$ & \\
\hline 16. & $\begin{array}{l}\text { Technical } \\
\text { Assistance (TA) } \\
\text { and Capacity } \\
\text { building }\end{array}$ & $\begin{array}{l}\text { Local Farmers' } \\
\text { organization }\end{array}$ & $\begin{array}{l}\text { TA through sustainable } \\
\text { agricultural network }\end{array}$ & $\begin{array}{l}\text { Good } \\
\text { agricultural } \\
\text { practice (GAP) }\end{array}$ & \\
\hline
\end{tabular}




\section{Appendix 3}

Appendix 3. The descriptive statistic of respondents to the conjoint survey

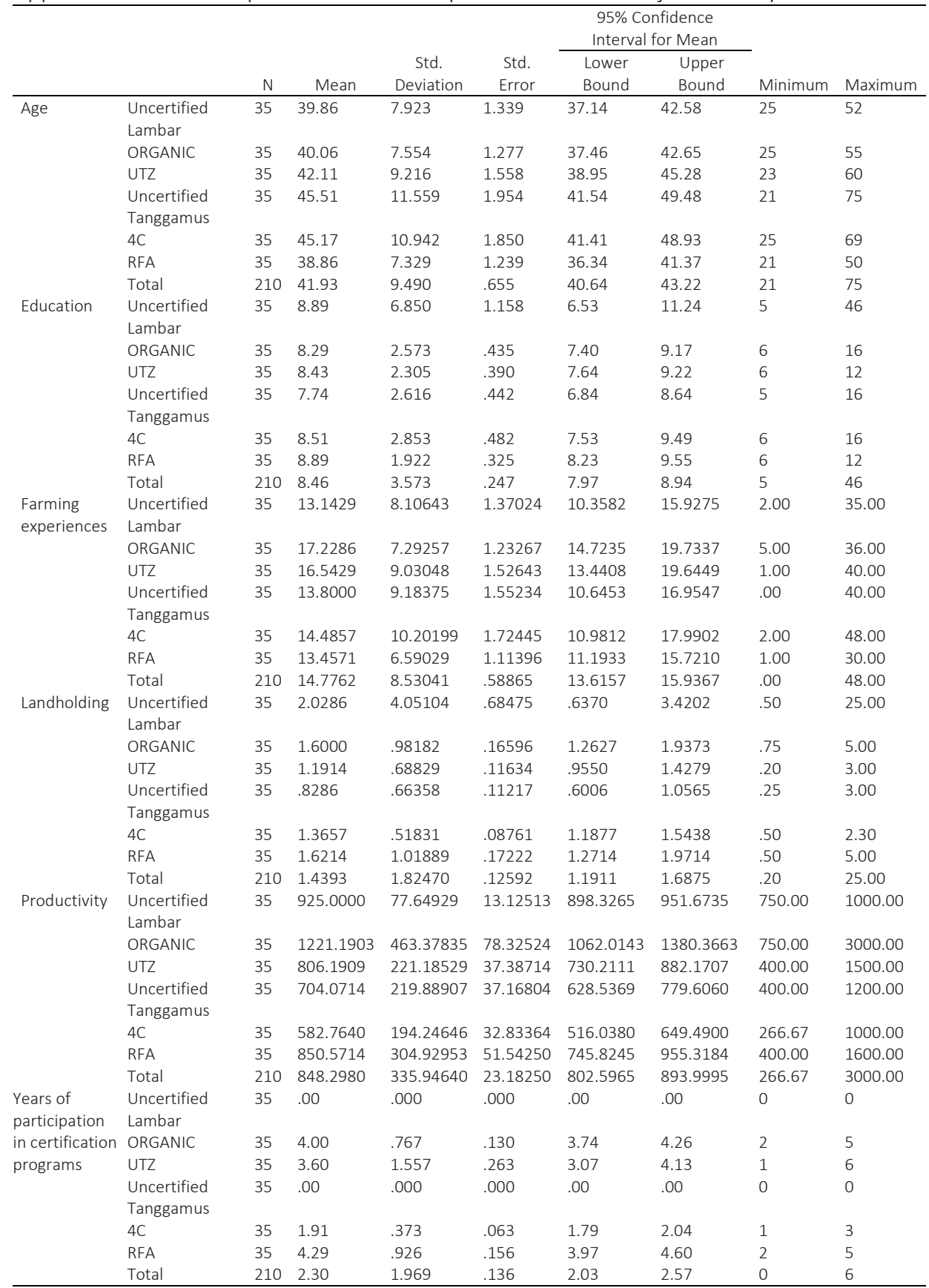




\section{Appendix 4}

Appendix 4. Variable, operationalization and question item

\begin{tabular}{|c|c|c|c|}
\hline & variable & operationalization & question item \\
\hline \multirow{3}{*}{ 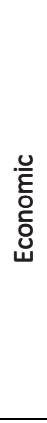 } & Price premium & $\begin{array}{l}\text { Prospect of price } \\
\text { premium }\end{array}$ & $\begin{array}{l}\text { - I do not join certification because it cannot } \\
\text { promise financial benefits (real) } \\
\text { - I joined certification for obtaining financial } \\
\text { benefits (real) }\end{array}$ \\
\hline & $\begin{array}{l}\text { Increased } \\
\text { productivity }\end{array}$ & $\begin{array}{l}\text { Prospect of increased } \\
\text { productivity }\end{array}$ & $\begin{array}{l}\text { - I believe that joining certification can } \\
\text { improve coffee productivity. (ideal) } \\
\text { - I joined certification for improving my } \\
\text { productivity (real) }\end{array}$ \\
\hline & $\begin{array}{l}\text { Improved } \\
\text { quality }\end{array}$ & $\begin{array}{l}\text { Prospect of increased } \\
\text { quality }\end{array}$ & $\begin{array}{l}\text { - I believe that joining certification can } \\
\text { improve coffee quality.(ideal) } \\
\text { - I joined certification for improving the } \\
\text { quality (real) }\end{array}$ \\
\hline \multirow[t]{4}{*}{ 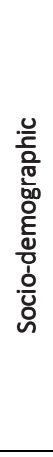 } & $\begin{array}{l}\text { Coffee as main } \\
\text { source of } \\
\text { income }\end{array}$ & $\begin{array}{l}\text { - Coffee income } \\
\text { (Rupiah) } \\
\text { - Income from other } \\
\text { crops (Rupiah) } \\
\text { - Off-farm income } \\
\text { (Rupiah) }\end{array}$ & $\begin{array}{l}\text { - What are the prices for your coffee (per } \\
\text { KG)? How many kilogram coffees per } \\
\text { harvest? } \\
\text { - What are the other crops that you } \\
\text { cultivate? How many kilograms per } \\
\text { harvest? What are the prices for them? } \\
\text { What are your off-farm activities? How } \\
\text { much money do you gain from the } \\
\text { activities? }\end{array}$ \\
\hline & Farm size & Farm size in hectares & What is the size of your farm? \\
\hline & Age & Age in years & What is your age in years? \\
\hline & Education & Education in years & $\begin{array}{l}\text { How many years did you follow formal } \\
\text { schooling? }\end{array}$ \\
\hline \multirow{4}{*}{ 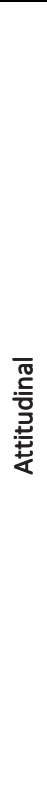 } & Environment & $\begin{array}{l}\text { - } \\
\text { - } \text { manvironmental farm } \\
\text { - } \text { inpducing chemical } \\
\text { - Increasing organic } \\
\text { input } \\
\text { - Increasing shade trees }\end{array}$ & $\begin{array}{l}\text { - Ideally, I reduce the use of chemical } \\
\text { inputs, even if it lowers profit. } \\
\text { - Ideally, I increase the use of organic input } \\
\text { even if it lowers profit. } \\
\text { - Ideally, I increase shade trees, even if it } \\
\text { lowers profit. } \\
\text { - I believe that I can sustain my farm by } \\
\text { managing it in an environmentally friendly } \\
\text { way }\end{array}$ \\
\hline & Taking risk & - $\quad$ Taking opportunities & $\begin{array}{l}\text { - Certification program is ideally followed } \\
\text { when there is an opportunity. } \\
\text { - I joined certification because I had the } \\
\text { opportunity }\end{array}$ \\
\hline & & $\begin{array}{l}\text { - } \quad \text { Avoidance/ playing } \\
\text { it safe }\end{array}$ & 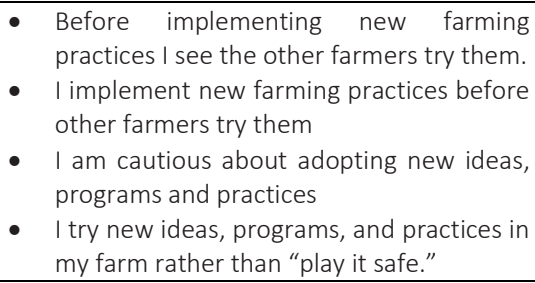 \\
\hline & $\begin{array}{l}\text { Seeking } \\
\text { information }\end{array}$ & $\begin{array}{l}\text { - Pro-actively seeking } \\
\text { information }\end{array}$ & $\begin{array}{l}\text { - I put a high effort to seek information. } \\
\text { - I wait for information to come to me. }\end{array}$ \\
\hline
\end{tabular}




\begin{tabular}{|c|c|c|c|}
\hline & & $\begin{array}{l}\text { - Increasing knowledge } \\
\text { by reading }\end{array}$ & $\begin{array}{l}\text { - I increase my knowledge by reading about } \\
\text { farming practices }\end{array}$ \\
\hline & & $\begin{array}{l}\text { - Increasing knowledge } \\
\text { by discussion }\end{array}$ & $\begin{array}{l}\text { - I increase my knowledge by having } \\
\text { discussions with other farmers/friends. }\end{array}$ \\
\hline \multirow{3}{*}{ 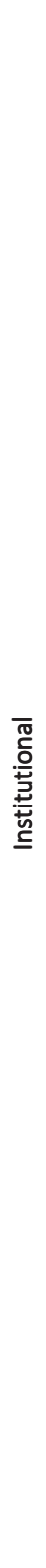 } & $\begin{array}{l}\text { Embeddedness } \\
\text { in well- } \\
\text { functioning } \\
\text { farmer groups }\end{array}$ & $\begin{array}{l}\text { - } \text { Regular meetings } \\
\text { - Collective actions } \\
\text { - } \text { Arisan/ community } \\
\text { gatherings } \\
\text { - Gotong royong/ } \\
\text { communal work } \\
\text { - Collecting, processing } \\
\text { and bargaining }\end{array}$ & $\begin{array}{l}\text { - Group organizes periodic informal } \\
\text { meeting to discuss farming-related issues } \\
\text { and to share knowledge and information. } \\
\text { Group organizes collective actions, for } \\
\text { example collectively buying farm inputs } \\
\text { (e.g. fertilizers, seeds, and tools), and } \\
\text { sharing cost (e.g. to buy hulling coffee } \\
\text { machine) } \\
\text { Group organize community gathering } \\
\text { arisan or alike to strengthen the } \\
\text { emotional bond of members } \\
\text { Group encourages members to help one } \\
\text { another, for example, by organizing } \\
\text { gotong royong (i.e. a form of communal } \\
\text { work or mutual aid) to build terrace, drain } \\
\text { terrace, and ridge in coffee plantations } \\
\text { Group collects, processes and controls the } \\
\text { quality of coffee harvests, and represents } \\
\text { its member to bargain with cooperative or } \\
\text { KUBE }\end{array}$ \\
\hline & $\begin{array}{l}\text { Embeddedness } \\
\text { in well- } \\
\text { functioning } \\
\text { KUBES }\end{array}$ & $\begin{array}{l}\text { - Information provision } \\
\text { - Facilitation/ support } \\
\text { in buying and } \\
\text { contacting } \\
\text { - Increase market } \\
\text { access } \\
\text { - Support in managing } \\
\text { finances }\end{array}$ & $\begin{array}{l}\text { - Cooperative or KUBE provides information } \\
\text { (e.g. coffee certification program, new } \\
\text { technology, and market information) } \\
\text { clearly and transparently } \\
\text { - Cooperative or KUBEs facilitate farmers to } \\
\text { buy fertilizers, seeds, tools and other farm } \\
\text { inputs } \\
\text { - Cooperative or KUBE facilitate farmers to } \\
\text { improve knowledge and skills, for } \\
\text { example, by contacting extension agents } \\
\text { or universities to give advices, training, } \\
\text { seminar and workshop } \\
\text { - Cooperative or KUBE improved market } \\
\text { access } \\
\text { Cooperative or KUBE is a better market } \\
\text { option than selling to intermediaries or } \\
\text { conventional markets } \\
\text { Cooperative or KUBE manage financial } \\
\text { saving of members } \\
\text { Cooperative or KUBE give credit or loan to } \\
\text { its members } \\
\text { Cooperative or KUBE pay farmers on time }\end{array}$ \\
\hline & $\begin{array}{l}\text { Presence of } \\
\text { near-by } \\
\text { Cooperative or } \\
\text { KUBE }\end{array}$ & $\begin{array}{l}\text { Distance between } \\
\text { farmer's household and } \\
\text { KUBE in KM }\end{array}$ & $\begin{array}{l}\text { How far your house location from } \\
\text { cooperative/ KUBE (in KM)? }\end{array}$ \\
\hline
\end{tabular}




\section{Appendix 5}

Appendix 5. Question items for all farmers

\begin{tabular}{|c|c|}
\hline $\begin{array}{l}\text { The perceived } \\
\text { benefits }\end{array}$ & Question items* \\
\hline \multirow[t]{9}{*}{ Economic } & It is easy for me to sell my coffee (Bacon, 2010; Rueda \& Lambin, 2013) \\
\hline & I can sell my coffee at different places (Mujawamariya et al., 2013) \\
\hline & $\begin{array}{l}\text { 3. The prices I receive for my coffee are good (Bacon, 2010; Ruben \& } \\
\text { Zuniga, 2011; Rueda \& Lambin, 2013) }\end{array}$ \\
\hline & $\begin{array}{l}\text { 4. I have good access to farming inputs (Benson, 2014; Beuchelt and } \\
\text { Zeller, 2013) }\end{array}$ \\
\hline & $\begin{array}{l}\text { 5. I have easy access to coffee processing equipment (Ruben \& Zuniga, } \\
\text { 2011) }\end{array}$ \\
\hline & $\begin{array}{l}\text { 6. I have good access to storage facilities (Bray et al., 2002; Raynolds et } \\
\text { al., 2004) }\end{array}$ \\
\hline & 7. I have good access to credit (Jena et al., 2015; Ruben \& Zuniga, 2011) \\
\hline & I have enough opportunities to save money (Bacon et al., 2008) \\
\hline & 9. I feel secure regarding land tenure (Ruben \& Zuniga, 2011) \\
\hline \multirow[t]{15}{*}{ Social/ community } & $\begin{array}{l}\text { 1. Access to health services is good (Bray et al., 2002; Jena et al., 2015; } \\
\text { Raynolds et al., 2004) }\end{array}$ \\
\hline & $\begin{array}{l}\text { 2. People receive proper assistances to build their houses (Bray et al., } \\
\text { 2002; Jena et al., 2015; Raynolds et al., 2004) }\end{array}$ \\
\hline & $\begin{array}{l}\text { 3. People receive proper assistance to renovate their houses (Bray et al., } \\
\text { 2002; Jena et al., 2015; Raynolds et al., 2004) }\end{array}$ \\
\hline & 4. Opportunity to have well education is high (Rueda \& Lambin, 2013) \\
\hline & $\begin{array}{l}\text { 5. Working opportunity is good for people in my area (Jena et al., 2015; } \\
\text { Valkilla, 2009) }\end{array}$ \\
\hline & Safe drinking water is available (van Rijsbergen et al., 2016) \\
\hline & Sanitary conditions are good (van Rijsbergen et al., 2016) \\
\hline & Funerals are well organized in my community (Place et al., 2004). \\
\hline & 9. Funerals are well financed in my community (Place et al., 2004). \\
\hline & 10. Wedding are well organized in my community (Place et al., 2004). \\
\hline & 11. Wedding are well financed in my community (Place et al., 2004). \\
\hline & $\begin{array}{l}\text { 12. Arisan (i.e., a form of social gathering) is common in the community } \\
\text { (Place et al., 2004). }\end{array}$ \\
\hline & $\begin{array}{l}\text { 13. Gotong royong (i.e., a form of communal work) is regular in community } \\
\text { (Place et al., 2004). }\end{array}$ \\
\hline & $\begin{array}{l}\text { 14. We have strong social relationships in our community (Bray et al., } \\
\text { 2002; Jena et al., } 2015\end{array}$ \\
\hline & $\begin{array}{l}\text { 15. People are willing to help one another in community (Bray et al., 2002; } \\
\text { Jena et al., 2015) }\end{array}$ \\
\hline \multirow{4}{*}{$\begin{array}{l}\text { Representation } \\
\text { and/or } \\
\text { negotiation }\end{array}$} & $\begin{array}{l}\text { 1. I feel my interests are represented in governmental authorities (Bacon, } \\
\text { 2010; Taylor et al., 2005) }\end{array}$ \\
\hline & $\begin{array}{l}\text { 2. I feel my interests are represented in firms or businesses (Bacon, 2010; } \\
\text { Beuchelt and Zeller, 2013; Taylor et al., 2005) }\end{array}$ \\
\hline & $\begin{array}{l}\text { 3. I feel there is enough negotiation with the exporters (Bacon, 2010; } \\
\text { Beuchelt and Zeller, 2013; Taylor et al., 2005) }\end{array}$ \\
\hline & $\begin{array}{l}\text { 4. I think I have strong bargaining power over buyers (Bacon, 2010; Rueda } \\
\& \text { Lambin, 2013; Taylor et al., 2005) }\end{array}$ \\
\hline
\end{tabular}


Capacity building 1. I have a good opportunity to enhance my knowledge on farming practices (Bitzer et al., 2013; Raynolds et al., 2004; Ruben \& Zuniga, 2011 ; Utting, 2009)

2. I have a good opportunity to develop my farming skills (Adong, 2014; Elder et al., 2012; Ruben \& Zuniga, 2011; Utting, 2009)

3. I can easily find information regarding farming inputs (Adong, 2014; Bitzer et al., 2013)

4. I can easily access information regarding market price (Ruben \& Zuniga, 2011; Utting, 2009)

5. I receive trainings on technical aspects (e.g., how to use chemical inputs, new tools, new technique etc.) regularly (Adong, 2014; Elder et al., 2012; Ruben \& Zuniga, 2011; Rueda \& Lambin, 2013)

6. I receive trainings on managerial aspects (e.g., how to make bookkeeping, how to make a plan etc.) regularly (Ruben \& Zuniga, 2011; Rueda \& Lambin, 2013)

7. I meet extension workers regularly (Bray et al., 2002; Raynolds et al., 2014; Ruben \& Zuniga, 2011; Utting, 2009)

8. It is easy to get help from agricultural experts (Bray et al., 2002; Raynolds et al., 2004; Ruben \& Zuniga, 20118)

9. Helps from agricultural experts solve my problems (Bitzer et al., 2013; Raynolds et al., 2004; Ruben \& Zuniga, 2011; Utting, 2009)

10. I can freely express my opinion in a meeting (Elder et al., 2012; Jena et al., 2015)

11. I can use my rights to vote in an election (Elder et al., 2012; Jena et al., 2015; Parrish et al., et al., 2005)

Networking and

1. I know farmers from other groups pretty well (Bacon, 2010; Kilpatrick, 2007; Taylor et al, 2005; Taylor et al., 2005)

/or partnership

2. I can easily contact farmers from other groups (Bacon, 2010; Kilpatrick, 2007; Place et al., 2004; Taylor et al., 2005)

3. We collaborate with other groups (Bacon, 2010; Place et al., 2004; Taylor et al., 2005)

* Measured by Likert scale, ranging from 1 to 5 (1= strongly disagree; $2=$ disagree; 3=neutral; $4=$ agree; $5=$ strongly agree) 


\section{Summary}

Coffee is consumed by millions of people and has become part of their daily diets. Although coffee is mostly produced by smallholders in the South, the majority of coffee traded globally is currently controlled by large traders and/or roasters from the North. Since the 1990s, large multinational traders and/or roasters have been the main coffee suppliers in Northern markets, and they invest in coffee-producing countries to sustain their business operations through a direct connection with coffee smallholders. Together with NGOs, these businesses intervene in the coffee sector through establishing sustainability standards and certifications, which impact smallholders' livelihoods, their interaction with environments, their local production systems, and trade networks' structures. In the Northern market, the businesses and NGOs raise the awareness of consumers regarding sustainability issues in the smallholder coffee production system. Sustainability standards and certifications have become a trademark of agricultural business and this trend will likely continue as major corporations are becoming increasingly interested in the sustainability agenda. At the bottom of value chain, however, smallholder producers need to make sense of this trend, decide on how to react, given their preferences and social-economic opportunities. This dissertation particularly focusses on the problem perceptions and reactions to private certifications by smallholder farmers, whom the dissertation regards the 'gatekeepers' of sustainable change as they need to change their practices first to induce meaningful effects in the coffee system.

The dissertation is composed of six chapters. Chapter one is introductory and is subdivided into nine sections. The chapter provides a profile of Indonesian coffee smallholders, an overview the Indonesian coffee sector and also illustrates the world of certifications in Indonesia. Theoretical perspectives regarding (the debates on) sustainable standards and certifications are discussed, followed by research aims and research questions. Rather than take a managerial approach as most of previous studies did, this dissertation particularly focusses on the problem perceptions and reactions to private certifications by smallholder farmers. The main objective of this dissertation is to explore barriers and opportunities that smallholders envisage with participation in sustainability standards and certifications, and to reflect on what this implies for a pathway towards a more sustainable coffee production. To this end, smallholder preferences for certification attributes, explanations for participations, their perceptions on the benefits different organizations and certification schemes in different domains, and the implementation capacity of Indonesian Standard Coffee or ISCoffee (as a government initiative) are explored in details to better understand and interpret the process towards a more sustainable coffee production in Indonesia. The 
main objective is further explicated into three specific aims. The first aim is to examine the position of smallholders as gatekeepers of sustainability. The second aim is to assess smallholders' interpretation of the process of value creation through sustainability standards and certifications. The third and the final aim is to explore the implications (of these objectives) for a more sustainable coffee production. The aims are subsequently explicated into the research questions: What values do farmers attach to sustainability standards and certifications? How and to what extent do these values correspond to the intervention logic of sustainability certification? What does this imply for the process towards a more sustainable coffee production in Indonesia? The chapter closes by explaining scientific and policy relevance of the research and illustrating sustainability pathway for a more sustainable coffee production in Indonesia.

Chapter two examines preferences of coffee smallholder farmers in Indonesia for coffee certification attributes. This chapter is based on the premise that standard setting organizations, in order to be (more) acceptable to farmers, should consider farmer preferences. If certification schemes do not correspond to farmer's preferences, they may not be dedicated to comply with the certification principles, and some may even not be willing to participate. The contribution of the chapter to previous studies is twofold. First, it examines the preferences for coffee certification from a southern producers' perspective, and from an Indonesian perspective in particular. Second, it includes and compares the preferences of smallholders participating in global certification schemes (UTZ, Rainforest Alliance/RA, and 4C), a local certification scheme (Inofice), and smallholders who do not participate in any certification program. The chapter also describes the methods (conjoint analysis and qualitative interviews) and provides an overview of the respondents. Based on the analysis, it is concluded that smallholder preferences regarding the certification schemes are primarily economically driven, implying that certification is still weakly institutionalized at a farmer level. In general, farmers in different certification schemes are rather comparable in terms of their preferences. The most preferred attribute level is the presence of price premium followed by environmental conservation, a price differential against uncertified coffee, farmer groups or cooperatives as target, emphasis on fairness, price differentials based on coffee bean sizes, no contract and no pre-finance.

Chapter three provides the explanations of Indonesian farmer participation in sustainability standards and certification schemes. The chapter aims to contribute to the discussions about farmers' motivations to participate in certification by bringing some order in the current explanations. The particularly aim is to answer the question of the relative importance of the various explanations by reformulating the explanations into hypotheses and connected variables, which were further operationalized in relevant questionnaire items. After illustrating the current explanations for smallholders 
joining certification (based on literature on sustainability standards and certification for coffee), the chapter presents the hypotheses based on a literature review, describes the methods (operationalization of the hypotheses, Heckman selection model with a twostep procedure and an overview of the respondents) and presents the results. The chapter concludes that some explanatory variables for joining certification differ among the schemes, but economic motivations are the strongest explanatory factor behind farmer participation in certification.

Chapter four concentrates on perceived impacts (benefits) of certification and farmer organization from the Indonesian smallholders' point-of-view. This chapter contributes to knowledge as to whether farmers participating in different certification schemes and in different organizational structures perceive (different) benefits in relation to different benefit domains. The chapter argues that perceptions are considered to be important because they significantly determine farmers' satisfaction that influences whether the farmers continue their participation in certification and organization. The existing literature, however, largely fails to understand these perceptions and the extent to which they differ for farmers belonging to different organizational forms or coffee certification schemes. The chapter first provides a literature review on potential benefits of farmer organization and certification, including an overview of a division of potential benefits in five domains and farmer organizations in Indonesia. Three hypotheses on the influence of organizations and certification schemes on perceived benefits are subsequently proposed, followed by the explanation of the methods (to test groups' differences and to explain variation in perceived benefits) and an overview of the respondents (i.e., farmers certified with 4C, UTZ, Fairtrade/FT and RA, and uncertified farmers, and organized and unorganized farmers). The chapter closes by arguing that efforts to better organize farmers may, from a farmers' benefits point of view, be equally effective as attempts to involve more farmers in certification. The implication is that the improvement of farmer organizations should not only be viewed as a part of the certification process but also as a direct means to achieve a more sustainable coffee production.

Chapter five examines the implementation capacity of ISCoffee (Indonesian Standard Coffee) as a public standard and certification initiated by the Indonesian government. This chapter evaluates the opportunities and barriers in the process of implementing the public standards and whether the public standard can become a viable alternative to Northern-based private standards and certifications. By doing so, the chapter contributes to the literature on the emerging trend of Southern sustainability standards and certifications, which are viewed as a reaction to the Northern-based private standards initiated by businesses and NGOs. The chapter firstly illustrates the recent development of Southern sustainability standards and certifications, arguing that the 
implementation capacity of the public standards and certification are still uncertain and unexplored. The chapter then provides some background knowledge on ISCoffee, its underlying principles and criteria, and differences between ISCoffee and private standards followed by the analytical framework and the findings. The chapter closes by concluding that both ISCoffee's implementation capacity is limited and, in the short term, the public standard will not become a viable alternative to Northern-based private standards and certifications.

Chapter six summarizes the main conclusions from the empirical chapters and links these to the main research objectives. The general conclusion is that coffee smallholders respond positively to opportunities that enable them to participate in the global coffee supply chain through joining sustainability standards and certification, but they need relevant incentives such as financial and technical support services to innovate and participate successfully in dynamic and competitive markets. The pathway toward sustainability in coffee production in Indonesia requires a systemic perspective, which is explicated through 'building blocks' to better understand particular patterns or issues that need to address. The building blocks include an enabling environment, production and market characteristics, availability of alternative livelihoods, and the degree of competition among producers. The chapter closes by discussing future study needs in this field. 


\section{Ringkasan}

Kopi dikonsumsi oleh jutaan orang di dunia dan telah menjadi bagian dari konsumsi sehari-hari mereka. Meskipun kopi kebanyakan diproduksi oleh para petani di belahan bumi bagian Selatan, sebagian besar kopi yang diperdagangkan secara global saat ini dikendalikan oleh pedagang besar dan/atau industri pengolah kopi yang berasal dari belahan bumi bagian Utara. Sejak tahun 1990an, pedagang multinasional dan/atau pengolah kopi multinasional telah menjadi pemasok kopi utama di pasar belahan bumi bagian Utara, dan mereka berinvestasi di negara-negara produsen kopi untuk mempertahankan operasi bisnis mereka melalui hubungan langsung dengan petani kopi. Bersama LSM, bisnis-bisnis ini melakukan intervensi di sektor kopi melalui penetapan standar dan sertifikasi keberlanjutan, yang selanjutnya berdampak pada mata pencaharian petani, interaksi mereka dengan lingkungan, sistem produksi lokal, dan struktur jaringan perdagangan mereka. Di pasar belahan bumi bagian Utara, para bisnis dan LSM meningkatkan kesadaran konsumen mengenai isu keberlanjutan dalam sistem produksi kopi yang dikelola petani dan kemudian mengklaim standar dan sertifikasi keberlanjutan adalah instrumen yang dapat menangani masalah tersebut. Standar dan sertifikasi keberlanjutan semakin tidak dapat dipisahkan dari merek dagang bisnis pertanian dan tren ini cenderung berlanjut karena perusahaan besar semakin tertarik dengan agenda keberlanjutan dan sertifikasi. Namun, di dasar rantai nilai, para petani perlu memahami tren ini, memutuskan bagaimana bereaksi, berdasarkan preferensi dan pertimbangan peluang sosial-ekonomi mereka. Disertasi ini berfokus pada persepsi dan reaksi para petani Indonesia terhadap standar dan sertifikasi keberlanjutan. Disertasi ini menganggap petani sebagai 'penjaga gerbang' perubahan berkelanjutan karena mereka perlu mengubah praktik mereka terlebih dahulu untuk dapat memberi efek yang berarti pada sistem perkopian yang lebih luas.

Disertasi ini terdiri dari enam bab. Bab satu adalah pengantar dan terbagi menjadi sembilan bagian. Bab ini memberikan gambaran tentang profil petani kopi Indonesia, sektor kopi Indonesia dan juga dunia sertifikasi di Indonesia. Perspektif teoretis mengenai (perdebatan tentang) standar dan sertifikasi berkelanjutan dibahas, diikuti oleh tujuan penelitian dan pertanyaan penelitian. Dibandingkan dengan mayoritas penelitian sebelumnya yang melakukan pendekatan manajerial, disertasi ini berfokus pada persepsi masalah dan reaksi terhadap sertifikasi swasta oleh para petani. Tujuan utama dari disertasi ini adalah untuk menggali hambatan dan peluang yang dirasakan petani dengan berpartisipasi dalam standar dan sertifikasi keberlanjutan, dan untuk merefleksikan apakah partisipasi ini merupakan sebuah jalur atau arah yang tepat menuju produksi kopi yang lebih berkelanjutan. Untuk lebih memahami dan menafsirkan proses menuju produksi kopi yang lebih berkelanjutan di Indonesia, 
disertasi ini menggali secara dalam preferensi petani terhadap atribut sertifikasi, penjelasan mengenai partisipasi petani di dalam sertifikasi, persepsi mereka tentang manfaat organisasi dan skema sertifikasi yang berbeda dalam domain yang berbeda, dan kapasitas implementasi Standar Kopi Indonesia atau ISCoffee (sebagai sertifikasi versi pemerintah). Tujuan utama disertasi dijelaskan lebih lanjut dalam tiga tujuan spesifik. Tujuan pertama adalah untuk menganalisis posisi petani sebagai penjaga pintu gerbang keberlanjutan produksi kopi. Tujuan kedua adalah untuk memahami interpretasi petani tentang proses penciptaan nilai yang dilakukan oleh standar dan sertifikasi keberlanjutan. Ketiga dan merupakan tujuan akhir adalah untuk mengeksplorasi implikasi (dari keseluruhan tujuan) terhadap produksi kopi yang lebih berkelanjutan. Tujuan-tujuan tersebut kemudian ditransformasikan ke dalam pertanyaan penelitian: Nilai-nilai apa yang diinterpretasikan oleh petani terhadap standar dan sertifikasi keberlanjutan? Bagaimana dan sejauh mana nilai-nilai ini sesuai dengan logika atau maksud dan tujuan dari intervensi sertifikasi keberlanjutan? Apakah implikasi dari tujuan-tujuan ini bagi proses produksi kopi yang lebih berkelanjutan di Indonesia? Bab ini ditutup dengan ilustrasi tentang jalur keberlanjutan untuk mencapai produksi kopi yang lebih berkelanjutan di Indonesia, dan relevansi penelitian terhadap ilmu pengetahuan dan kebijakan.

Bab dua membahas tentang preferensi petani kopi di Indonesia terhadap atribut sertifikasi kopi. Bab ini didasarkan pada premis bahwa sertifikasi, agar lebih dapat diterima oleh petani, harus mempertimbangkan preferensi petani. Jika skema sertifikasi tidak sesuai dengan preferensi petani, mereka mungkin tidak berdedikasi untuk mematuhi prinsip sertifikasi, dan bahkan mungkin tidak bersedia untuk berpartisipasi. Bab ini berkontribusi dua hal terhadap penelitian sebelumnya. Pertama, studi tentang preferensi sertifikasi kopi dari perspektif produsen Selatan, dan dari perspektif petani di Indonesia pada khususnya. Kedua, Bab ini membandingkan preferensi petani yang berpartisipasi dalam skema sertifikasi global (UTZ, Rainforest Alliance, dan 4C), skema sertifikasi lokal (Inofice), dan petani yang tidak berpartisipasi dalam program sertifikasi apapun. Bab ini juga menjelaskan metode (analisis conjoint dan wawancara kualitatif) dan memberikan gambaran umum tentang responden. Berdasarkan hasil analisis, dapat disimpulkan bahwa preferensi petani terhadap skema sertifikasi terutama berkaitan dengan aspek ekonomi, menyiratkan bahwa pembauran atau penerimaan sertifikasi di tingkat petani masih lemah.

Bab tiga memberikan penjelasan-penjelasan tentang (alasan) partisipasi petani Indonesia dalam standar dan sertifikasi keberlanjutan. Bab ini berkontribusi terhadap diskusi tentang motivasi petani untuk berpartisipasi dalam sertifikasi dengan memberikan tingkatan (rangking) terhadap penjelasan-penjelasan yang ada saat ini. Tujuan utamanya adalah untuk menjawab pertanyaan tentang kepentingan relatif dari 
berbagai penjelasan dengan merumuskan kembali penjelasan tersebut menjadi hipotesis dan variabel yang berkaitan dan selanjutnya dioperasionalkan dalam item kuesioner yang relevan. Berdasarkan literature tentang standar dan sertifikasi keberlanjutan untuk kopi, bab ini menyajikan hipotesis tentang penjelasan-penjelasan berkaitan dengan partisipasi petani dalam sertifikasi, menjelaskan metode (operasionalisasi hipotesis, regresi logistik biner dan ikhtisar dari responden) dan menyajikan hasil penelitian. Bab ini menyimpulkan bahwa variabel-variabel yang menjelaskan alasan mengikuti sertifikasi adalah berbeda di antara skema sertifikasi, namun motivasi ekonomi merupakan faktor penjelas terkuat yang mendorong petani berpartisipasi dalam sertifikasi.

Bab empat berkonsentrasi pada persepsi tentang dampak (manfaat) yang dirasakan oleh petani Indonesia terhadap sertifikasi dan organisasi petani. Bab ini memberikan kontribusi terhadap pengetahuan mengenai apakah petani yang berpartisipasi dalam skema sertifikasi yang berbeda dan dalam struktur organisasi yang berbeda merasakan manfaat yang berbeda (dalam domain-domain manfaat yang berbeda). Bab ini berpendapat bahwa persepsi adalah penting karena menentukan kepuasan petani yang selanjutnya mempengaruhi apakah petani melanjutkan partisipasi mereka dalam sertifikasi dan organisasi. Literatur yang ada sebagian besar gagal untuk menjelaskan tentang persepsi ini dan sejauh mana persepsi petani tersebut berbeda antara petani yang terlibat dalam organisasi dan sertifikasi yang berbeda. Bab ini pertama kali memberikan tinjauan literatur tentang manfaat potensial dari organisasi dan sertifikasi bagi petani, termasuk gambaran tentang pembagian manfaat potensial di lima domain dan organisasi petani di Indonesia. Tiga hipotesis mengenai pengaruh organisasi dan skema sertifikasi terhadap manfaat yang dirasakan petani kemudian diusulkan, diikuti dengan penjelasan tentang metode dan ikhtisar responden. Bab ini ditutup dengan kesimpulan bahwa upaya untuk mengorganisasikan petani dengan lebih baik, dari sudut pandang petani, sama efektifnya dengan upaya untuk melibatkan lebih banyak petani dalam sertifikasi.

Bab lima membahas kapasitas implementasi ISCoffee (Standar Kopi Indonesia) sebagai standar dan sertifikasi publik yang diprakarsai oleh pemerintah Indonesia. Bab ini memberikan analisis kapasitas implementasi ISCoffee dengan mengevaluasi kemungkinan peluang dan hambatan dalam proses penerapan standar publik dan apakah standar publik dapat menjadi alternatif untuk standar dan sertifikasi swasta yang diinisiasi dunia belahan Utara. Dengan demikian, bab ini berkontribusi pada literatur mengenai tren peningkatan standar dan sertifikasi keberlanjutan dari Selatan, yang dipandang sebagai reaksi terhadap standar swasta berbasis di Utara yang diprakarsai oleh bisnis dan LSM. Bab ini pertama-tama menggambarkan perkembangan terakhir dari standar dan sertifikasi keberlanjutan dari Selatan dan berargumen bahwa 
kapasitas implementasi dari standar tersebut masih belum pasti dan belum dipelajari secara lebih mendalam. Bab ini kemudian memberikan pengetahuan tentang latar belakang ISCoffee, prinsip dan kriteria yang mendasarinya, dan perbedaan antara ISCoffee dan standar-standar swasta, diikuti dengan kerangka analisa dan hasil penelitian. Bab ini ditutup dengan kesimpulan bahwa kapasitas implementasi ISCoffee masih terbatas dan, dalam jangka pendek, standar publik tersebut tampaknya tidak akan menjadi alternatif yang layak untuk standar dan sertifikasi swasta berbasis di Utara.

Bab enam merangkum kesimpulan utama yang berasal dari disertasi ini dan menghubungkannya dengan tujuan penelitian utama. Bab ini memberikan ringkasan hasil-hasil penelitian empiris disertasi ini, yang mencakup nilai-nilai yang dipahami dan ditampakkan oleh petani terhadap standar dan sertifikasi keberlanjutan. Kesimpulan umumnya adalah bahwa petani kopi memberi tanggapan positif terhadap peluang yang memungkinkan mereka berpartisipasi dalam rantai global pasokan kopi melalui standar dan sertifikasi berkelanjutan. Namun, petani memerlukan insentif yang relevan seperti layanan dukungan finansial dan teknis untuk dapat berinovasi dan berpartisipasi secara sukses dalam persaingan pasar yang dinamis dan kompetitif. Jalur menuju keberlanjutan produksi kopi di Indonesia memerlukan perspektif sistemik yang dijelaskan oleh 'blok pembangunan' untuk lebih memahami pola atau masalah krusial yang perlu ditangani. Akhirnya, bab ini ditutup dengan diskusi tentang penelitian yang dibutuhkan dibidang ini di masa depan. 


\section{Valorization}

Valorization is defined as 'the process of creating value from knowledge, by making this knowledge available and suitable for economic and social exploitation and to translate this knowledge into products, services, processes and new business' (The Maastricht Valorization Centre/ MVC).

Most of scientific-based knowledge, including the knowledge of this dissertation, is obtained through researches within the atmosphere of universities and academic community. The definition of valorization, however, implies that the knowledge produced by a dissertation is not merely intended for the academic community. The knowledge should also be available and suitable for wider audiences that mostly exist outside the university, and in my case this includes farmer communities, the government and nongovernmental organizations. Available and suitable knowledge is understood as accessible and applicable knowledge. Accessible implies that communities can access the knowledge without difficulties whereas applicable implies that the communities can understand the knowledge and therefore can apply it. Next, I will elaborate how the knowledge produced by this dissertation will be valorized to wider communities, especially in the Indonesian context where my research took place, in relation to my (permanent) position as a university researcher/lecturer in the country.

\section{Tri Dharma Perguruan Tinggi in Indonesia}

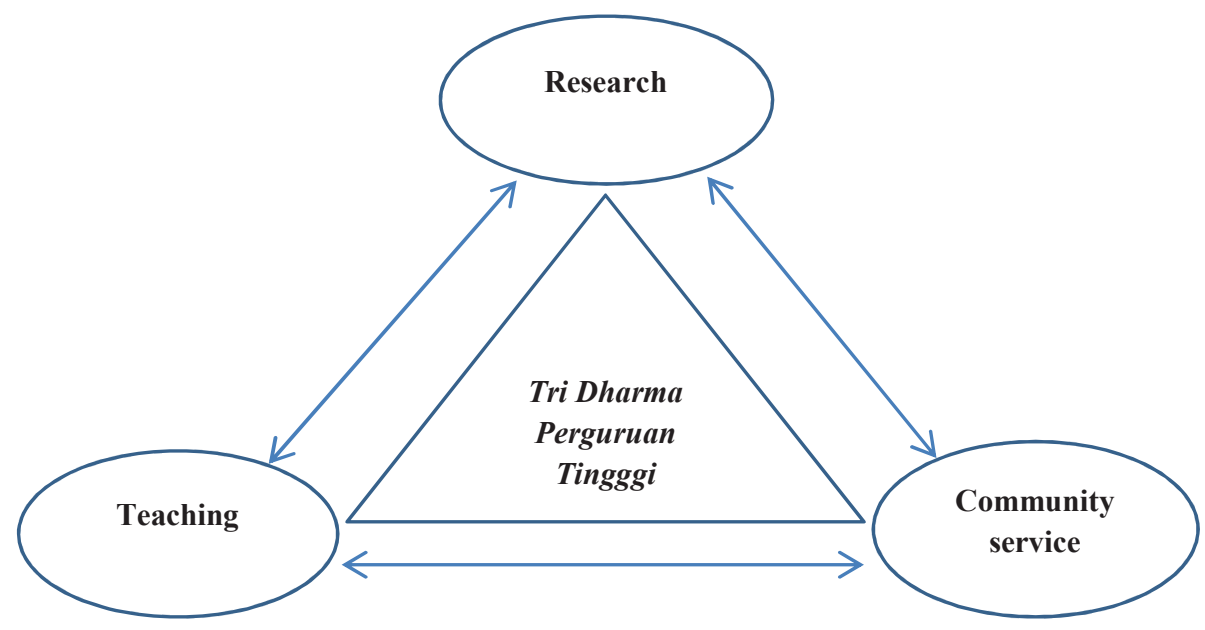

Direktorat Jendral Pendidikan Tinggi (DIKTI) or the Directorate General of Higher Education of Indonesia formally mandates all of the universities in the country to 
perform tri dharma perguruan tinggi. The term tri dharma perguruan tinggi comes from Sanskrit language: "Tri" means three and "Dharma" means obligations. Tri dharma perguruan tinggi therefore literally means three obligations.

At a university level, academic communities are responsible for realizing the tri dharma perguruan tinggi that covers: teaching, research, and community service. The three obligations are delivered with quality, focus and relevance to the needs of not only academic communities but also audiences outside universities; and these obligations are not viewed as isolated responsibilities, but are considered interrelated duties. Academic communities must fulfil these obligations through their activities taking place either inside or outside universities. Currently, I am working for a state university in my home province as a (junior) lecturer/researcher at the Agribusiness Department of the Faculty of Agriculture. Therefore, I am also responsible for performing the tri dharma perguruan tinggi throughout my career.

\section{Research}

Researches have a very important role in producing knowledge and in advancing science and technology. However, knowledge, science, and technology are less useful if they are restricted to academic communities or only preserved in the university library. Researches should be understood in a broad sense that means they should support the development of both academic and non-academic parts of society. This further implies that non-academic audiences should be able to access and understand the knowledge produced by researches.

Most of the researchers are familiar with publishing scientific articles to contribute knowledge to academic literatures. Tri dharma perguruan tinggi suggests that researchers can also valorize the knowledge through teaching and community service, through which the researchers may also receive feedbacks and new ideas for future studies.

\section{Knowledge valorization through teaching activities}

In Indonesia, the level of higher education is known as strata, ranging from strata 1 (S1) for bachelor programs, strata 2 (S-2) for master programs and strata 3 (S-3) for doctoral programs. Colleague students consist of not only young students (usually fulltime students) but also relatively mature, experienced students (usually part-time students). The latter commonly enroll as S-2 or S-3 students and have classroom meetings in the late afternoon and/or in the weekend. In this way these students, who are mostly employees of public and private sectors, can pursue their master or doctoral 
degrees without leaving their current jobs. As a PhD holder, I am entitled to teach students at all strata (from S-1 to S-3).

During completing of my dissertation, I learned and practiced to think systematically and to enhance my writing skills through developing good 'argumentation lines' and 'writing structure'. The former refers to the reasoning and thought pattern used to explain or deliver particular messages whereas the latter refers to the arrangement of argumentation line in such a way that information or explanation can be conveyed systematically (especially in writing). I reflect that most of Indonesian students - based on my own experiences - have a rather limited guidance on how to develop skills in constructing good argumentation lines and structure their writings. This can be one of noticeable weaknesses of the current education system and for this reason I will guide my students to develop these skills. S-1 and S-2 students will be given a weekly assignment to discuss particular topics (with particular questions), and each group of students needs to write a paper and then present it in front of the class. To motivate them, I will grade every paper and presentation, which will contribute to the final grade. S-3 students have to make proposals for their research projects that must be presented to and accepted by a (doctoral program) committee. They therefore need to practice, in a relatively independent way, to develop good argumentation lines and writing structures, and then manifest them in their individual research proposals.

I used to teach two courses: the basic of agricultural extension, and the management of agribusiness. The former discusses the topics related to the empowerment of smallholders through (informal) educations such as trainings, groups/individual discussions, and demonstration plots. The latter covers topics such as management, organization, marketing, profitability and trade of agricultural products. Both courses focus on the agricultural sector smallholders are part of. As my dissertation focusses on coffee smallholders, the knowledge produced by the dissertation is relevant for the courses, which can further function as a medium for valorizing the knowledge to students. My dissertation has specifically produced knowledge regarding smallholders' preferences, explanations for participation in certification, and their perceptions regarding the benefits from participation in sustainability standards and certifications. The knowledge produced by the dissertation is novel scientific knowledge and, when it is informed to students with a combination of teaching methods (e.g., discussion, multimedia presentation, and problem solving etc.), it may trigger lively discussions during teaching activities. The knowledge may further inspire the students to think about their own research topics and to explore more knowledge supporting a more sustainable coffee production or the sustainability of other agricultural commodities. 
In addition to regular-classroom teachings, I used to be involved and will be re-involved in specific academic courses/programs such as homestay, kuliah kerja nyata (KKN), and praktik kuliah lapangan (PKL). Homestay is an outside-classroom learning process intended for new students of the Faculty of Agriculture. In homestay, the students stay with farmers' families for around two weeks to observe the realities of agriculture and farmers in rural areas. KKN is rather similar to homestay in the sense that that students must stay in rural areas with farmer families. KKN is, however, compulsory for the students who have completed the majority of their mandatory courses. KKN also involves students across different faculties and requires them to stay longer in rural areas (usually more than one month). PKL is a student fieldwork for completing a bachelor thesis. Many students of the agricultural faculty do PKL in the rural areas where their homestay and/or KKN take place (because they have identified problems and did preliminary observations). Different from homestay and KKN, however, PKL is allowed to be conducted in the public and private sector, depending on students' research topics.

The knowledge produced by my dissertation provide insights into the realities of smallholders in rural areas, and before students leaving for homestay, KKN or PKL, they will be trained on how to communicate effectively with local (farmer) communities. This training will enable them to analyze situations, to discuss and to transfer the knowledge to the farmer communities. The students are also expected to realize that the farmers may respond with a rather challenging feedback if they feel the information/knowledge differs from their existing knowledge or experiences. This often happened during my fieldworks when I had discussions with farmers. If debates can be avoided, discussions can go smoothly and farmers may further understand that there is new, alternative knowledge produced by researches that contradict their existing knowledge and/or experiences. This in turn opens opportunity for the farmers to accept the knowledge.

During homestay, KKN, or PKL, I will visit the students and together we will arrange meetings with the hosts (e.g., village leaders, farmers etc.) to have discussions and to share knowledge and experiences. The students will be evaluated on what they have learned from the activities in the rural areas, what knowledge that they have transferred to farmers, and what feedbacks that they received from the farmers. Overall, in my view, students' potential contributions to knowledge valorization cannot be neglected because homestay, KKN, and PKL are generally appreciated and welcomed by farmers and/or rural communities. During such activities, students may transfer knowledge to the communities while also learning from their (farming) practices and experiences. In the future, students will likely work in various sectors, and they will be my potential networks to valorize the knowledge of my researches to even wider audiences. 


\section{Knowledge valorization through community service}

Community service means informing, disseminating, and applying information and technology obtained through research for the benefits of society. This activity is nonprofit oriented, supported by universities, and can be done either by individuals or by groups of researchers. Through community service, I expect that farmers, governments, and private sectors will benefit from my researches, and they will use the knowledge and give feedbacks to improve my researches.

I have some experience with working with the government and farmers. For example, before doing my $\mathrm{PhD}$, I was involved in a consultant team to improve a training curriculum for public extension officers. The team's members were from local government and university, and my involvement in the team was prearranged by my university as its commitment to collaborate with the local government. In addition, I was involved in klinik pertanian keliling, which is a unit within the faculty of agriculture aiming to convey knowledge and expertise to farmers by providing, for example, trainings and consultations. Through the consultant team and klinik pertanian keliling, I have developed connections with farmers and local governments, which further enhanced during my PhD fieldworks. These connections are valuable for valorizing the knowledge of my researches.

Regarding the (local and national) governments, it will be relevant to inform them about the importance of taking into account farmers' preferences and interests in their policies and/or programs. It will also be appropriate to inform them about the implementation capacity (of programs). ISCoffee will be a relevant example and can show the governments the importance of analyzing implementation capacity for any strategic programs (prior to their actual implementation). For farmers, on the other hand, it is crucial to enhance their understanding and awareness of the concept of sustainable coffee production and how the agricultural system functions. It is therefore important to inform them that, for example, tangible (economic) benefits cannot be sustained in the long term without appreciating socio-environmental aspects of coffee production. If farmers understand this, it is expected that they may change their perspective and improve their capacities to meet the requirements for a more sustainable coffee production.

Furthermore, for the efficacy and efficiency of knowledge valorization at a farmer level, in my view, what should be improved are connections with key people in rural areas. These people are local actors who daily interact and speak the same language with their local communities, and more importantly they are generally respected persons in the communities. These local actors include informal leaders (e.g., religious leaders), village 
leaders, extension workers, and institutional leaders (e.g., KUBE and cooperative leaders, woman group leaders, and youth organization leaders). These local actors may contribute significantly to knowledge valorization due to their abilities to motivate farmers to be involved in discussions and trainings. In my view, nurturing relationships with these local actors is important for at least three reasons. First, the relationships potentially enhance the applicability and the availability of research knowledge in rural areas, including shortening the lag time between the end of my research and the use of the research results. Second, the relationships can speed up the process of delivering feedbacks (from farmers) in order to be followed up in further researches. Third, the relationships can enhance the relevance of my researches to better address farmers' needs and problems.

\section{Knowledge valorization facilitated by university}

With specific units that focus on managing research and community service, universities are the main supporters for enhancing knowledge valorization. In my university, the units are called LP (Lembaga penelitian/research unit) and LPM (lembaga dan pengabdian masyarakat/ community service unit) respectively. LP and LPM aim to facilitate collaborations among researchers and to improve connections between academic and non-academic communities. In other words, LP and LPM function as doors for an effective and efficient linkage between communities inside and outside the university. Through LP and LPM, my university provides resources that I can use to valorize my research knowledge by, for example, organizing workshops, seminars, and training equipped with various media (e.g., video and other multimedia presentations, web-blog etc.).

Another alternative for valorizing knowledge is a knowledge sharing forum like a blog on the internet. Facilities to create such a forum are readily available but the issue is how to promote and encourage people to use it. One plausible way is to link and integrate the forum to the websites of university, faculty, and department as well as LP and LPM. In this way, the forum may be effective in sharing research knowledge and inducing discussions in relation to the attempts to improve sustainability in agricultural production. As there is no one approach that fits to all conditions of smallholders, discussions are important to generate ideas for establishing relevant approaches that fit to particular conditions of smallholders and, at the same time, generate ideas for future researches. One of the topics discussed will be, for example, how to enhance smallholders' contributions to sustainability in coffee production by addressing their production challenges (low productivity and quality, and climate-change vulnerability), compliance to sustainability principles (standards and certification), and poor living conditions. It will be important to motivate farmers and relevant stakeholders to be 
involved in the discussions; they can visit the forum to pose questions, share information/knowledge, and discuss specific issues related to agriculture/coffee sector. In summary, the forum is intended to facilitate communication among researchers and knowledge users (e.g., farmers, agricultural extensions, NGOs, and policy makers), which in turn may enhance opportunity for them to collaborate. Mediated by the internet, the forum potentially reaches extensive audiences and therefore extends the coverage of knowledge valorization. 


\section{Acknowledgements}

I would never have been able to finish my dissertation without the guidance of my promotors, co-promotor, and my advisors, help from friends, and support from my family and wife. I am incredibly grateful for all of you who stood by to support me along the way. Thank you for helping me during my PhD journey.

I am wholeheartedly thankful to my promotors: Prof. Pieter Glasbergen and Prof. Bustanul Arifin. Prof. Pieter, I do not know how to express my gratitude for your guidance that, from the initial to the final phase, has enabled me to develop an understanding of the subject, to write a good argumentation line and structure my work. I will never forget how you encouraged me when I was frustrated and how you convinced me when I was in doubt. Prof. Bustanul, thank you very much for encouraging me to involved in the SPIN-project, and for recommending me to the team of PhD recruiters. I would also like to thank my co-promotor, Dr. Ron Cörvers, for his support since the very beginning of my $\mathrm{PhD}$ and his continuously remind to keep my spirits high every time we met at ICIS.

I would like to express my deepest gratitude to Dr. Astrid Offermans, for her feedbacks and ideas, for patiently correcting and improving my writings, and for always opening her door for discussions with me. I would like to express my gratitude to my advisors, Dr. Surip Mawardi and Dr. Hanung Ismono. Pak Surip, thank you very much for helping me to better understand farmers and certification and also for assisting me with making contacts with respondents. Pak Hanung, thanks for your support during my fieldwork in the villages and for your help to connect me with potential respondents from the national and local governments.

Thank you also to Dr. Ari Damastuti and Prof. Wan Abbas Zakaria. Ibu Ari, thanks for your enthusiastic feedbacks during our discussions, your ideas on the relevance of understanding the local contexts in my research, and suggestions for improving my papers. Pak Abbas, thanks for your support, especially at the beginning of my study, as the dean of the Agricultural Faculty of Lampung University.

I would like to thank Anja van Bogaert who always was helpful with administrative procedures and financial matters. Thanks also to Annet Grol who was always willing to give special helps with housing and other administrative matters every time I came to Maastricht.

I would like to thank Nia, Ferdi, Atika, and Esther (Esa) who as good friends were always willing to help and to encourage by sharing your stories and even jokes during our PhD 
times. Thanks also for all ICIS colleagues, who have provided an excellent academic environment. I would absolutely have been a lonely person without you all.

I would also like to thank my parents, my elder sister Erni Saptiani, and younger brother Akhmad Idrus. They were always supporting me and encouraging me with their best wishes. I would like to thank my wife, Bena Erni. She was always there cheering me up and stood by me through the good and bad times. Last but not least, I would like to thank my sons M. Faris Elmuntasir and Rafa Irfan Mumtaz who always cheered me up through the phone when I was away in the Netherlands. Without you all, I would not have been able to thrive in my doctoral program. Thanks for joining me in this scholarly adventure - I could not have accomplished this feat without you by my side.

Muhammad Ibnu 


\section{List of Abbreviations and Acronyms}

$4 C$

AfDB

AICE

Anova

APEKI

BPS

BSN

CFC

COSA

Df

DIKTI

Disbun

$\operatorname{Exp}(B)$

FAO

FG

FGcooperative

FGD

FGKUBE

FLO

FT

GAPS

GCP

GDP

GI

GPN

GVC

ha

HKM

IBM-corps

ICCRI

$\mathrm{ICIS}$
Common Code for the Coffee Community

(the) African Development Bank

Association of Indonesian Coffee Exporters

Analysis of Variance

Asosiasi Petani Kopi Indonesia/Association of Indonesian

Coffee Farmers

Badan Pusat Satistik/Statistical center bureau

Badan standardidasi Nasional/Nasional Standardization

Agency

Common Fund for Commodities

(the) Committee on Sustainability Assessment

Degree of freedom (statistical test)

Direktorat pendidikan tinggi/ the Directorate General of Higher Education

Dinas Perkebunan/department of plantation

Exponentiated Beta coefficient

Food and Agricultural Organization

Farmer group

Farmer Group and cooperative

Focus Group Discussion

Farmer Group and KUBE

Fairtrade Labelling Organization

Fairtrade

Good Agricultural Practices

Global Coffee Platform

Gross Domestic Product

Geographical Indication

Global Production Network

Global Value Chains

hectare

Hutan Kawasan Masyarakat/ community-based forestry

management

International Business Machines Corporation

Indonesian Coffee and Cocoa research Institute

International Centre for Integrated Assessment and

Sustainable

Development 
ICO

ICS

IFAD

IFG

Inofice

ISCacao

ISCoffee

ISPO

ITC

$\mathrm{kg}$

KNAW

KPK

KPMG

KUBE

$\mathrm{m}$

MP4

MUST

NGO

OECD

Permentan

PP

RA

S.E

SAN

SCP

Sig.

$\mathrm{SNI}$

SPIN

SPSS

TCC

UNEP

UNFSS

USA

UTZ

UU
International Coffee Organization

Internal Control System

(the) International Fund for Agricultural Development Independent Farmer Group

Indonesian organic farming certification

Indonesian Standard Cocoa

Indonesian Standard Coffee

Indonesian Sustainable Palm Oil

International Trade Center

kilogram

Koninklijke Nederlandse Academie van Wetenschappen

Komisi Pemberantasan Korupsi/commission for corruption

eradication

Klynveld Peat Marwick Goerdeler

Kelompok Usaha Bersama/Joint-business group

meter

Making Markets Work Better for the Poor

Maastricht University Graduate School of Sustainability

Science

Non-Governmental Organization

Organization for Economic Cooperation and Development

Peraturan Menteri Pertanian/ the regulation of the Ministry

of Agriculture

Peraturan Pemerintah/the government regulation

Rainforest Alliance

Standard Error

Sustainable Agriculture Network

Sustainable Coffee program

Significance

Standar Nasional Indonesia/the National Standard of Indonesia

Scientific Programme Indonesia-Netherlands (SPIN)

Statistical Package for the Social Sciences

(the) Tropical Commodity Coalition

(the) United Nations Environment Program

(the) United Nations Forum on Sustainability Standards

United States of America

UTZ Certified

Undang-undang/ Law 
List of Abbreviations and Acronyms

VCA

VSS

WTO

$\Delta$
Value Chain Analysis

Voluntary Sustainability Standards

World Trade Organization

Changes compared to the previous year 


\section{About the Author}

Muhammad Ibnu was born in Bandar Lampung on May 18, 1979. He holds a Bachelor (2001) and Master (2005) of Agribusiness obtained from Bogor Agricultural Institute, Indonesia. During his studies, he obtained training mostly on quantitative analysis and subsequently developed major interests in marketing, economics, finances and statistics. He wrote his bachelor thesis

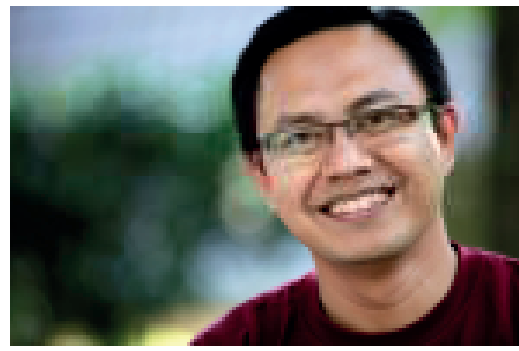
"Analysis of value added and marketing strategies of canned-pineapples produced by Great Giant Pineapple Company Lampung", and master thesis "Bond issuance by a regional government-owned bank in Indonesia: a feasibility study". Shortly after completing his Master degree, he was accepted as an academic staff member (lecturer/researcher) at the Agribusiness Department of the Faculty of Agriculture of Lampung University, Indonesia. In the Agribusiness Department, he joined the peer group of communication and extension and managed the computer laboratory of the study. During the time in the laboratory, he further developed his skills in computerbased mathematical models and statistical methods, with specific interests in linear programming, parametric and non-parametric statistics, the analytic hierarchy process (AHP), and structural equation modelling (SEM) analyses.

Ibnu accomplished his dream to study in the Netherlands in 2007. With a scholarship from the Indonesian government through the Ministry of Communication and Information technology, he enrolled in the master Management of Agro-Ecological Knowledge and Social Change (now master Development and Rural Innovation) at Wageningen University. There, he learned a wide range of topics, methodologies, theoretical frameworks and qualitative approaches in social science research. He finished the master in 2009, with the thesis "Farmers' intention to adopt technologies in paddy cultivation, a case study at Wonokarto and Sukoharjo villages in East-Lampung District Indonesia". For the master thesis, he built a decomposed model, based mainly on the combination of the Theory of Planned Behavior and the Technology of Acceptance Model. From this research framework he derived some hypotheses. He surveyed rice farmers to collect the data, and then he used his knowledge in structural equation modelling (SEM) analysis and in the Lisrel statistical-computer program to test the hypotheses. During the master study he actively took part in Perhimpunan Pelajar Indonesia (PPI) or Indonesian Student Association in Wageningen. 
Back from the Netherlands, Ibnu continued to work at Lampung University at the same faculty and department. In addition to regular teaching activities and researches, he was involved in a wider range of activities that took place both inside and outside the university. In the university, he joined Klinik pertanian keliling, which is a unit within the faculty of agriculture, aiming to provide consultation and transfer of knowledge and expertise to farmers. Outside university, he managed and supervised many activities in rural areas with the students of the agricultural faculty and was a member of a consultant team (a collaboration of university and local government) that worked on improving a curriculum for extension officers' training. Together with other researches from the Faculty of Agriculture and relevant stakeholders, Ibnu was involved in a project financed by the provincial government to improve the management of water irrigation in the rice-producing regions of Lampung province. Considering his knowledge and skills on quantitative analysis, he was often involved in local government projects contributing to the quantitative part of their feasibility studies.

Since May 2013, Ibnu enrolled as a PhD researcher at International Centre for Integrated assessment and Sustainable development (ICIS) Maastricht University. His PhD project was part of the Scientific Program Indonesia-Netherlands (SPIN) under the theme Social and Economic Development, and was financed by the Directorate General of Higher Education of Indonesia (DIKTI) and the Royal Netherlands Academy of Arts and Sciences (KNAW). His project was "Social and economic effects of coffee certification." He combined quantitative and qualitative approaches in his research to study the attributes that farmers address to livelihood improvements as a consequence of participating in sustainability standards and certifications. During his PhD training, he participated in seminars and workshops of the SPIN-project in the Netherlands and in Indonesia. He presented one of his empirical chapters of the dissertation at the 22nd annual conference of the International Sustainable Development Research Society (ISDRS) in Lisbon Portugal. After graduation, Ibnu will continue his academic carrier at Lampung University where his status is a government employee. In addition to teaching, he will do research and community service, and currently he is a member of Perhimpunan Ekonomi Pertanian Indonesia (PERHEPI) or the Association of Indonesian Agricultural Economists. 
